\title{
NON-COMPLIANCE IN WTO DISPUTE SETTLEMENT: ASSESSING THE EFFECTIVENESS OF WTO RETALIATION FROM ITS PURPOSE(S)
}

\author{
BY \\ MICHELLE ENGEL LIMENTA
}

\begin{abstract}
A thesis
submitted to the Victoria University of Wellington

in fulfilment of the requirements for the degree of

Doctor of Philosophy
\end{abstract}

Victoria University of Wellington

2012 
To my father

Yohanes Likumahu (10/1/1950 - 10/02/1999)

Promise fulfilled 


\section{Acknowledments}

I would like to thank Prof. Susy Frankel and Meredith Lewis, for their enthusiasm, encouragement, patience yet straightforwardness and dedication to the work of my thesis. I enjoy every intellectual discussion with both of them. Their academic contributions to the development of international trade/economic law have also inspired me.

I also thank Faculty of Law PhD advisor, Prof. Tony Angelo, for his advice and support during my tenure as a PhD student. He always has time to provide immeasurable assistance not only to me but also other $\mathrm{PhD}$ students.

Many thanks I deliver to my mother: Lily Widjaja; my sister and brother: Inge Widjaja and Michael Limenta. They are my beautiful "safe harbour" every time I felt exhausted with my study. I also thank my support person, Irene McDowall, for her unquestioning support prior, during, and after my oral defence.

I also acknowledge proof-reading assistance provided by Elisabeth Perham and Veronika Klauser.

Last but not least, the financial support from the Victoria University of Wellington is gratefully acknowledged. 


\section{TABLE OF CONTENTS}

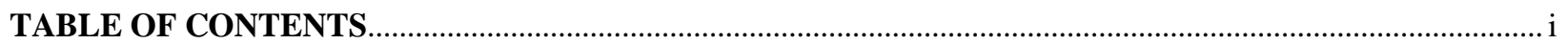

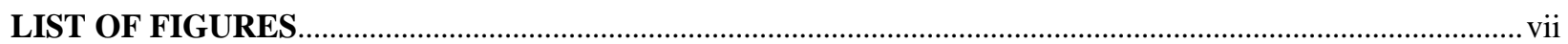

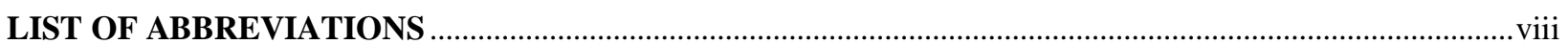

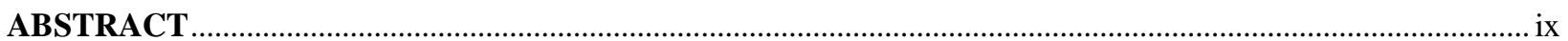

\section{CHAPTER ONE}

INTRODUCTION TO WTO REMEDIES IN THE CASE OF NON-COMPLIANCE...................................... 1

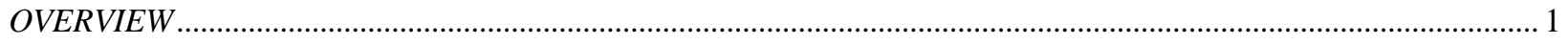

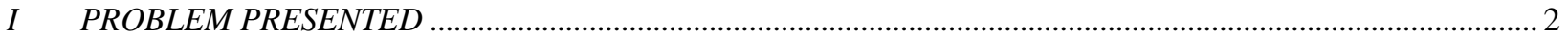

II INTRODUCTION TO WTO DSU REMEDIES: THE GOOD RECORD OF COMPLIANCE AND THE

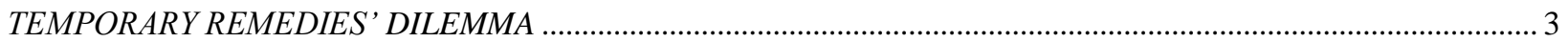

A FINAL REMEDY's GoOd RECORD VERSUS TEMPORARY REMEDIES' DILEMMAS ............................................... 4

B OtHER DILEMMAS RESULTING FROM THE IMPLEMENTATION OF RETALIATION: LESSONS FROM THE DISPUTES

1 The ability of developing countries to impose retaliatory measures

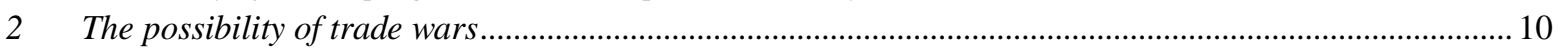

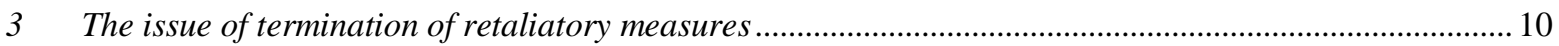

4 Continued non-implementation or procedural delay .............................................................................. 11

III OVERVIEW OF LITERATURE ON THE EFFECTIVENESS OF WTO REMEDIES, THE PURPOSE(S) OF RETALIATION, WTO LAW IN RELATION TO OTHER REGIMES, AND OPTION TO IMPROVE REMEDIES ..... 12

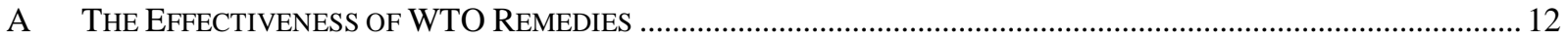

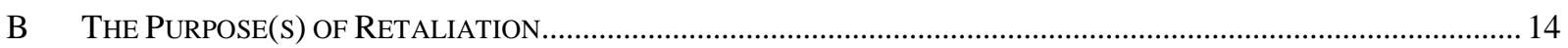

$1 \quad$ The lack of clarity of article 22: various alleged purposes emerge …………............................................. 14

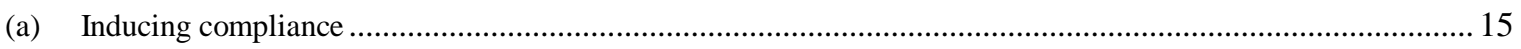

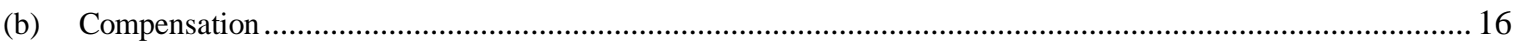

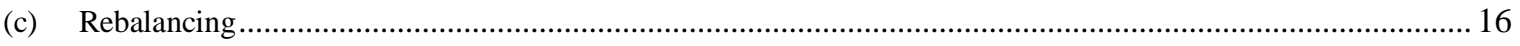

(d) "To deter inefficient breach but to encourage efficient breach" ...................................................................... 17

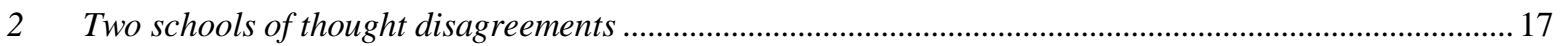

3 Providing a different standard in the SCM Agreement: Does it help to clarify the purpose(s)? ................ 20

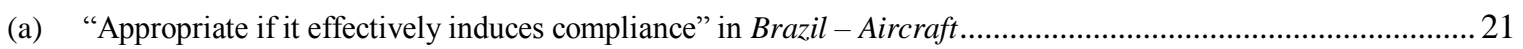

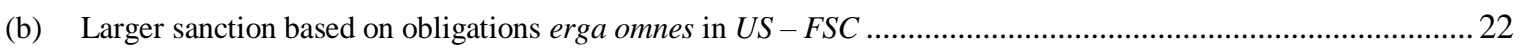

(c) Larger penalties as a punitive sanction in Canada - Aircraft II …….............................................................. 23

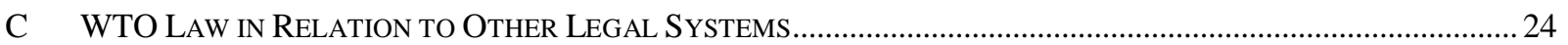

$1 \quad$ WTO law in relation to public international law ................................................................................... 24

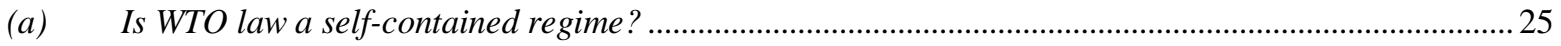

(b) WTO remedies and public international law remedies: inclusive or exclusive from the system?..........27

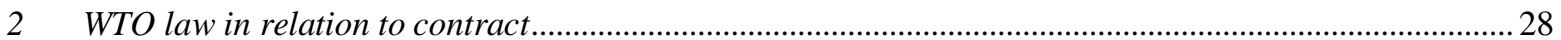

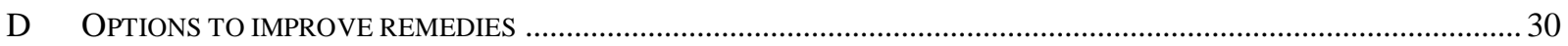




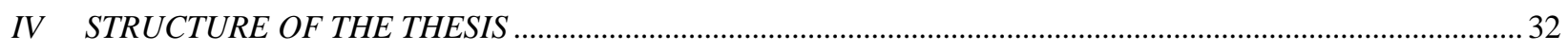

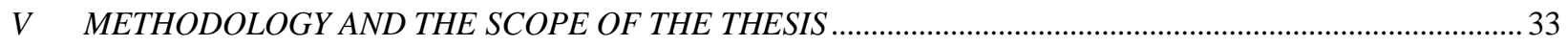

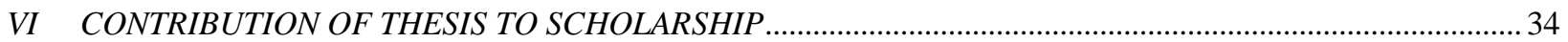

\section{CHAPTER TWO}

RETALIATION: SHORTCOMINGS AND REFORM PROPOSALS .............................................................. 36

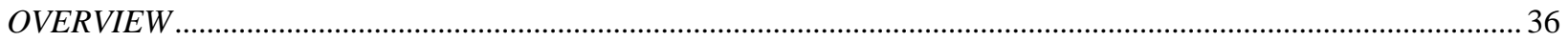

I NATURE, FEATURES AND SUBSTANTIVE RULES OF GATT/WTO RETALIATION ……………………..... 37

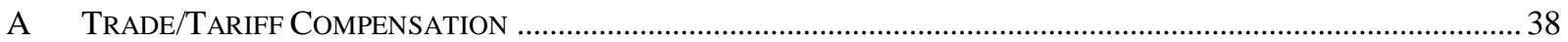

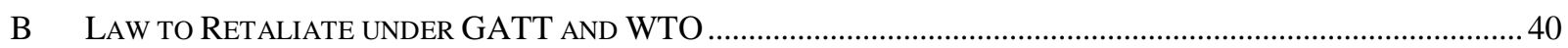

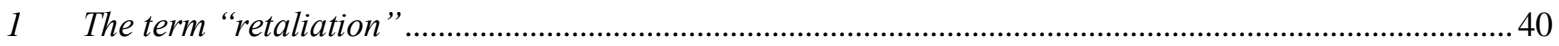

2 Retaliation practice under GATT dispute settlement .................................................................................. 41

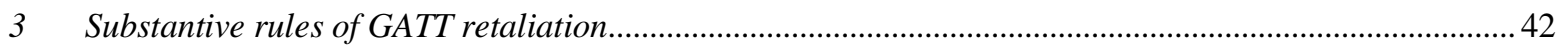

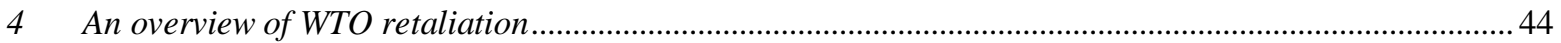

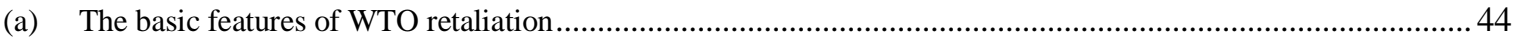

(i) Retaliation is the last resort and the sole remedy against non-compliance .................................................. 44

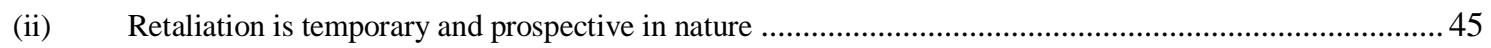

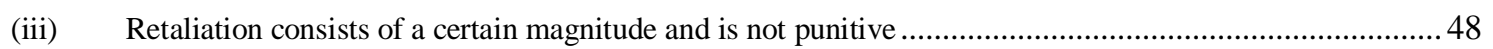

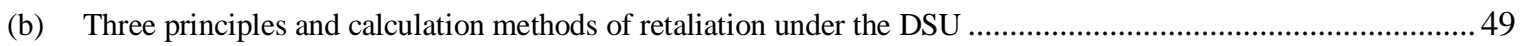

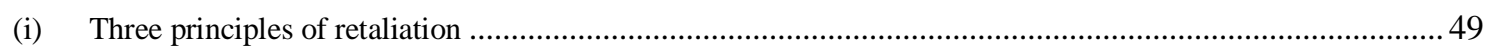

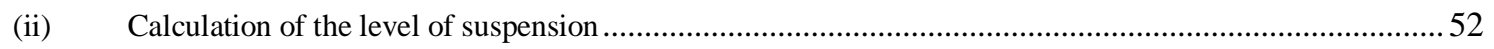

(iii) Determining the counterfactual and the method of calculation .....................................................53

$5 \quad$ Countermeasures under the SCM Agreement .................................................................................. 55

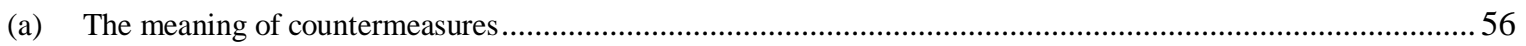

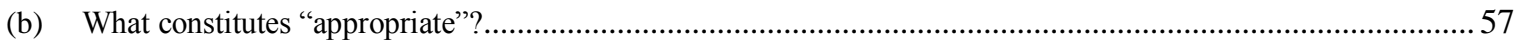

(i) It mainly corresponds to the amount of subsidy rather than the harm that has occurred.................................57

(ii) It allows more leeway than the word "equivalent".............................................................................5

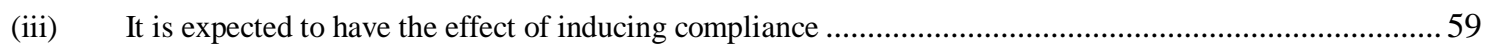

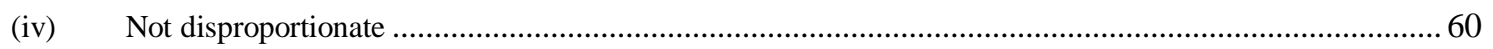

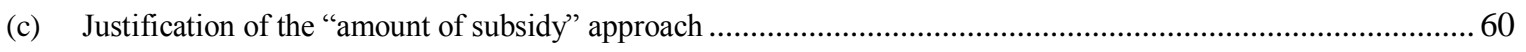

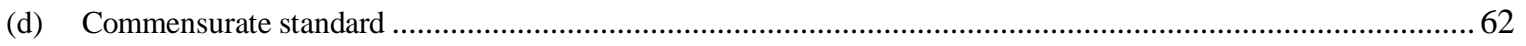

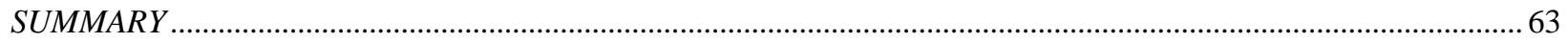

II THE SHORTCOMINGS AND PROBLEMS OF RETALIATION: ACADEMIC PERSPECTIVES AND

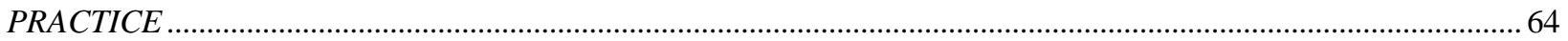

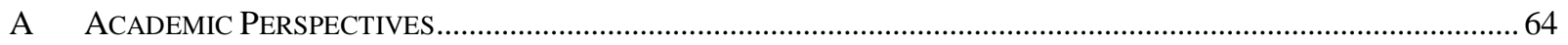

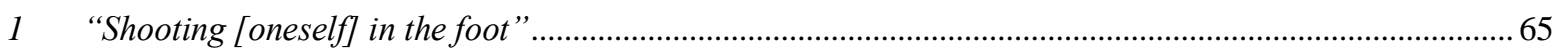

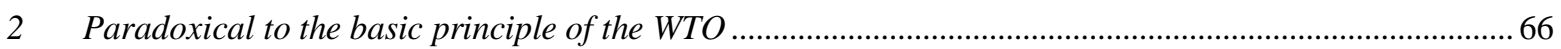

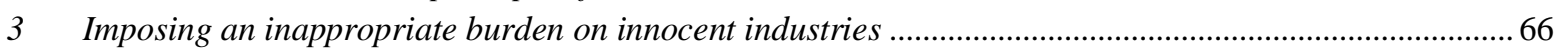

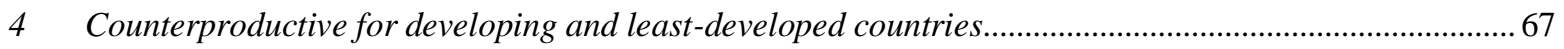

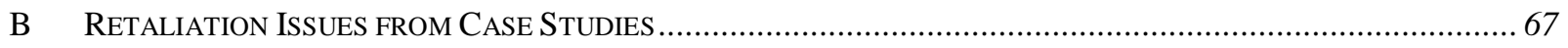

1 Lack of inducement power for the measures that have strong domestic political support.......................... 68

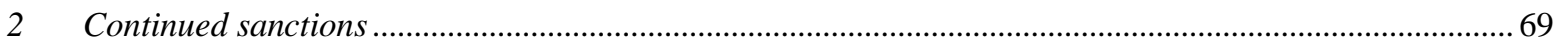

3 Lack of retaliating capacity for small developing countries and least-developed countries ...................... 69 
III PROPOSALS TO ENHANCE WTO RETALIATION AND THE CRITICISMS ……........................................ 71

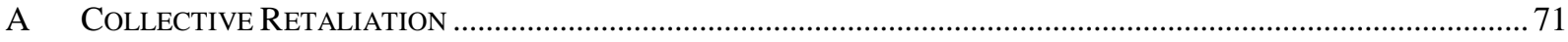

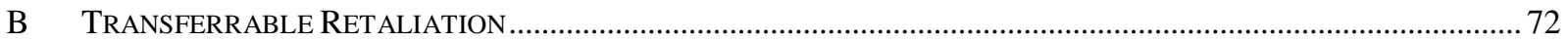

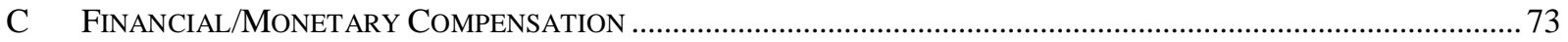

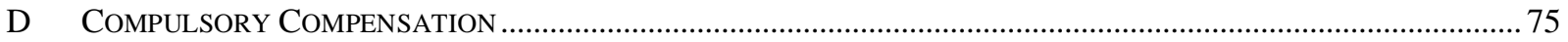

E Automatically Permitting Cross Retaliation for Developing Countries ....................................... 75

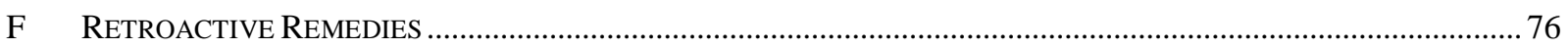

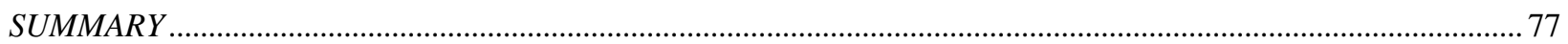

\section{CHAPTER THREE}

THE QUEST TO DISCOVER THE PURPOSE(S) OF RETALIATION...................................................... 78

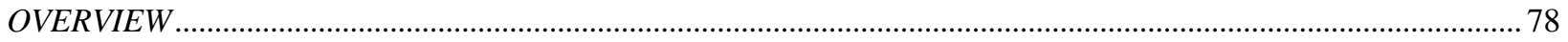

I DEFINITION OF EFFECTIVENESS AND THE IMPORTANCE OF THE PURPOSE .................................. 79

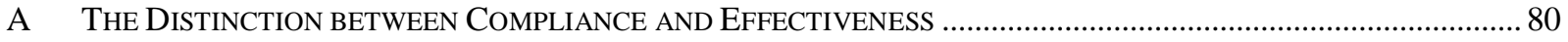

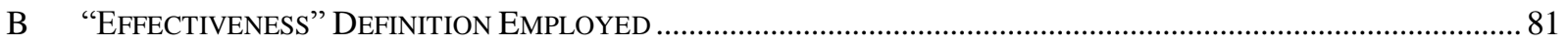

C The IMPORTANCE IN IDENTIFying the Purpose OF Retaliation AND the Quest to Discover IT ............. 82

II THE FIRST QUEST: INTERPRETATION OF ARTICLE 22 OF THE DSU .................................................. 84

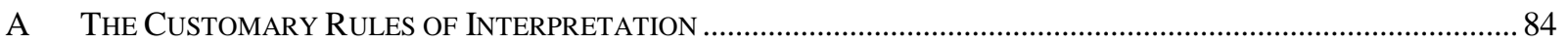

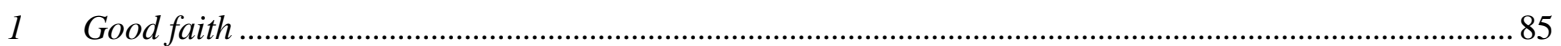

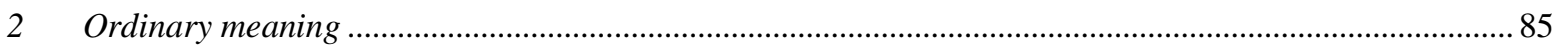

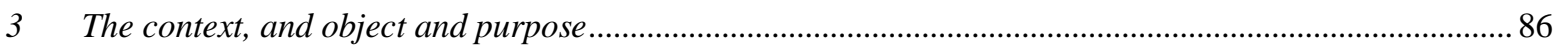

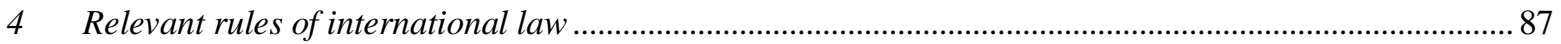

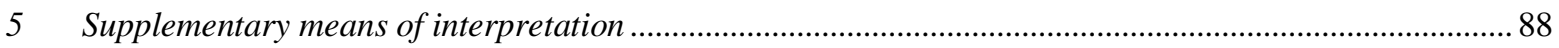

A CONTRACTING IN: THE CUSTOMARY RULES OF INTERPRETATION ............................................................... 89

B INTERPRETATION OF ARTICLE 22 OF THE DSU IN ACCORDANCE WITH THE CUSTOMARY RULES OF

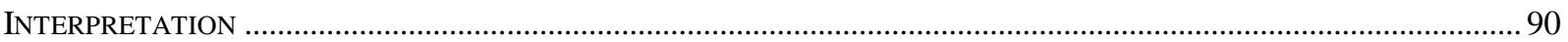

$1 \quad$ Multiple purposes from the context of Article 22 of the DSU ................................................................ 91

(a) The suspension "shall be temporary" under Articles 22.1 and 22.8 of the DSU................................................ 91

(b) The level of the suspension "shall be equivalent" to the level of the nullification or impairment under Article 22.4

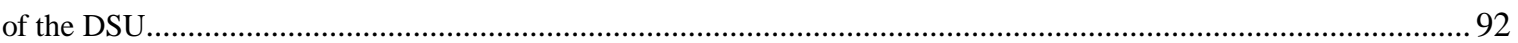

(i) "Equivalent" standard in relation to the "appropriate" standard under the SCM Agreement........................... 93

(c) The suspension shall only be applied until the inconsistent measure "has been removed" or the violator member "provides a solution to the nullification" or "a mutually satisfactory solution is reached" under Article 22.8 of the DSU .

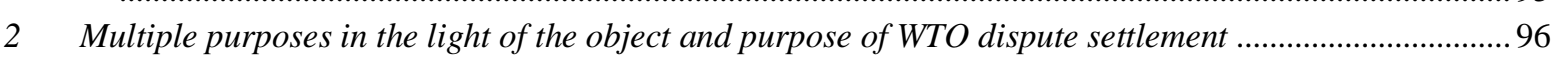

(a) Security and predictability: settlement of disputes through multilateral procedures and not through unilateral

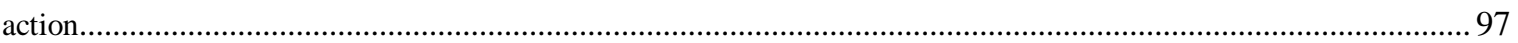

(b) Security and predictability: settlement of disputes through a positive solution ..................................................98

3 The assessment of remedies provisions under the ITO Charter and the GATT 1947 as supplementary

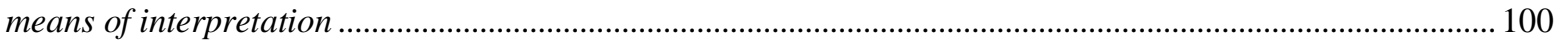

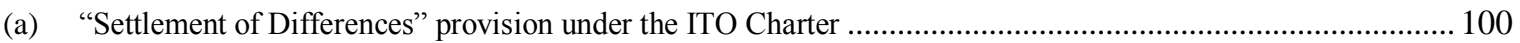

(b) "Appropriate and compensatory" remedy provision under the ITO Charter ..................................................... 102

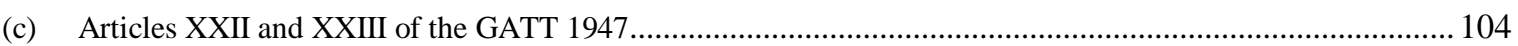

(d) "Appropriate" remedy provision under the General Agreement.................................................................... 104 
II THE SECOND QUEST: REFERENCE TO REMEDIES UNDER THE ILC DRAFT ARTICLES ON STATE

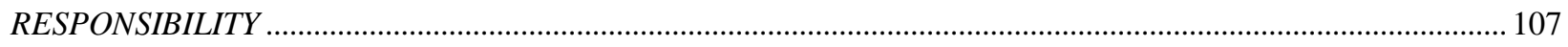

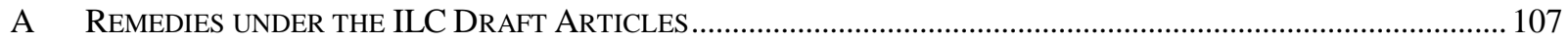

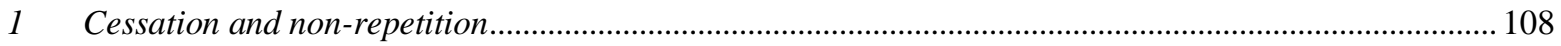

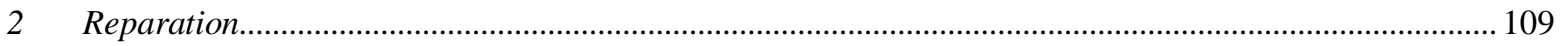

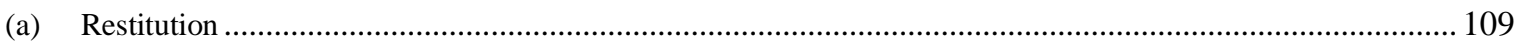

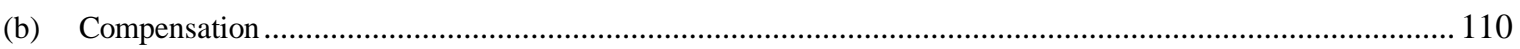

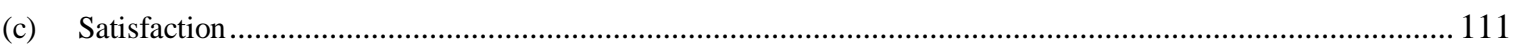

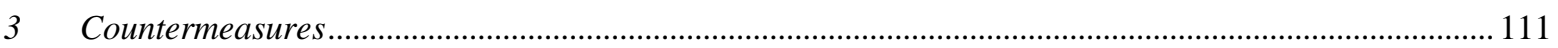

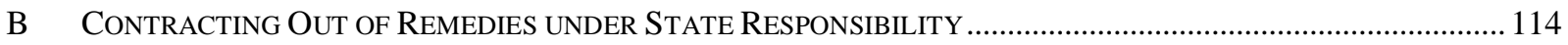

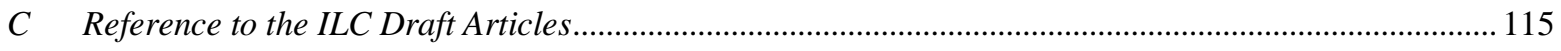

III THIRD QUEST: ACADEMIC DEBATES REGARDING THE PURPOSE OF RETALIATION ........................ 117

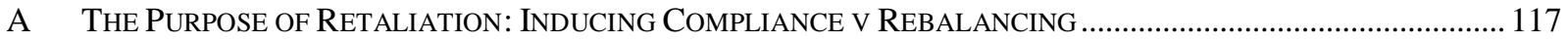

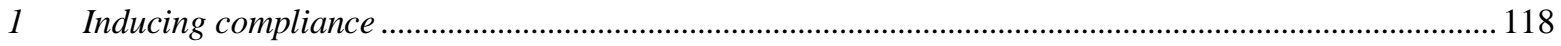

(a) It is in line with the DSU textual context and WTO rules as international law obligations ................................ 118

(b) The "equivalent" requirement does not mean that retaliation cannot induce compliance...................................119

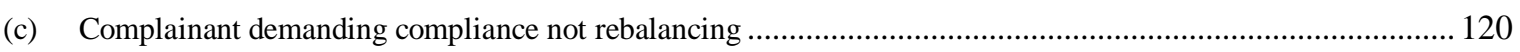

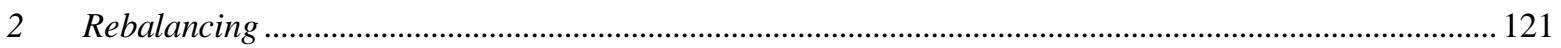

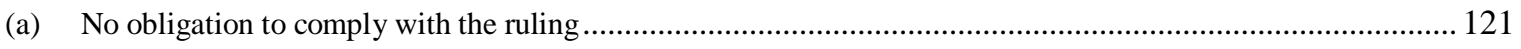

(b) Equivalent level requirement favours rebalancing purpose....................................................................... 122

(c) "Rebalancing" purpose is necessary to secure future commitments ............................................................. 122

IV FOURTH QUEST: ARTICLE 22.6 ARBITRATORS STATEMENTS WITH REGARD TO THE PURPOSE OF

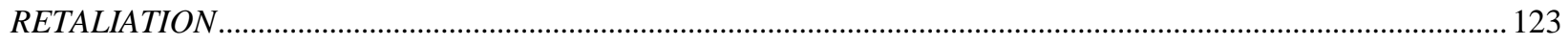

A The Purpose of "Inducing Compliance” with "Equivalent”" LeVEl Requirement ............................. 124

B The PURPoSE OF "INDUCING COMPLIANCE” WITH “APPROPRIATE” LEVEL REQUIREMENT ............................. 125

C INDUCING COMPLIANCE IS “NOT THE ONLY PURPoSE” PURSUEd By RETALIATION ......................................... 126

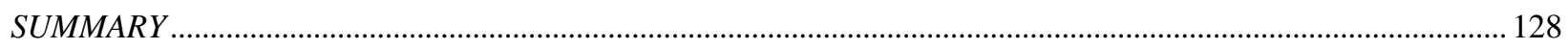

\section{CHAPTER FOUR}

\section{THREE LEVELS OF ASSESSMENT TO ARTICULATE THE MULTIPLE PURPOSES OF}

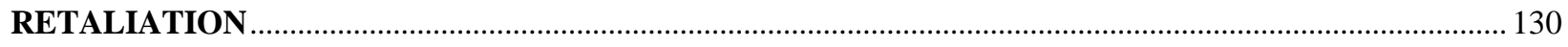

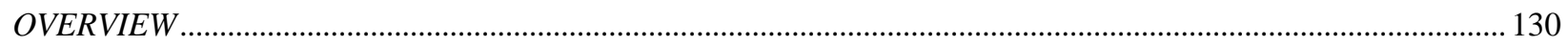

I FIRST LEVEL OF ASSESSMENT: IDENTIFYING THE NATURE OF WTO DISPUTE SETTLEMENT

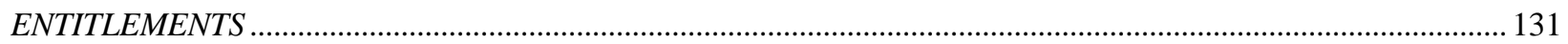

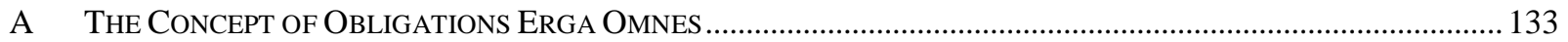

B The CONCEPT OF Multilateral and Bilateral OBligations In THE WORK OF THE INTERNATional LAW

CoMmitTEE ON THE LAW OF TREATIES AND STATE ReSPONSIBILITY ............................................................... 135

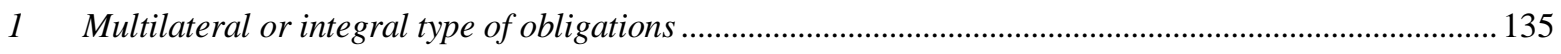

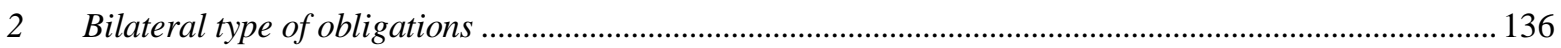

C Obligations Erga OmNes in Relation to Obligations ERga OMnes Partes........................................ 137

D Obligations ERga OMNeS IN Relation to Norms of Jus Cogens ........................................................... 138 
E The WTO Dispute SETtlement and Retaliation Obligations: INTEGRAL OR ReCiPROCAL IN NATURE ...

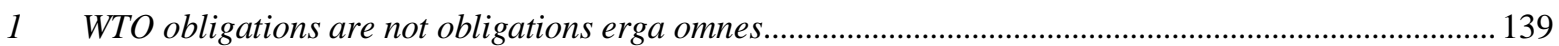

(a) WTO obligations do not qualify as obligations erga omnes.................................................................... 140

(b) WTO rules do not fall into the ambit of peremptory norm that give rise to obligations erga omnes.................. 140

2 Various WTO obligations are granted the status of obligations "erga omnes partes" ........................... 141

3 WTO dispute settlement and retaliation constitute bilateral obligations .................................................. 142

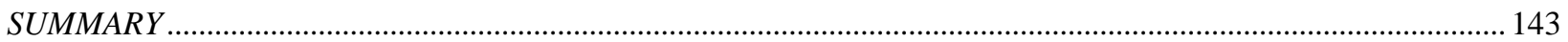

II SECOND LEVEL OF ASSESSMENT: DETERMINING THE PROTECTION RULES ................................... 144

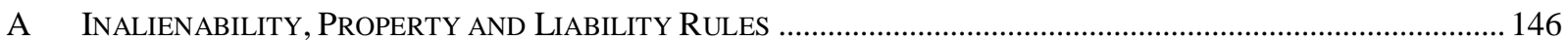

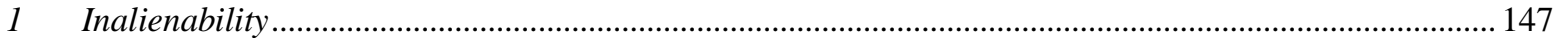

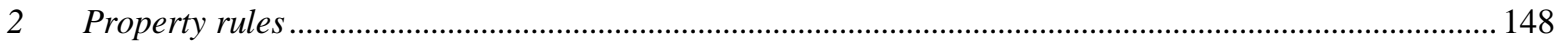

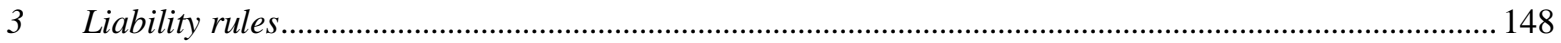

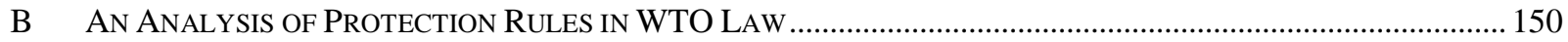

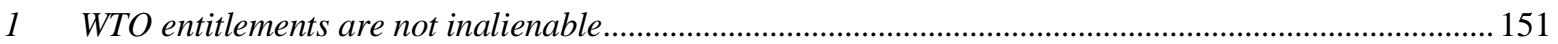

2 The debate over protection rules of WTO entitlements: property or liability rules .................................. 152

3 WTO law accommodates some amount of intra-contractual flexibility, yet WTO entitlements are

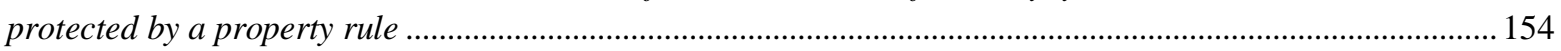

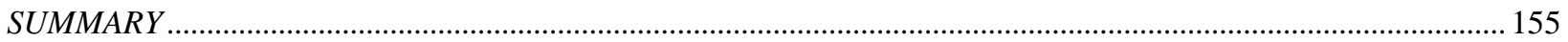

III THIRD LEVEL OF ASSESSMENT: BACK-UP ENFORCEMENT LEVEL IN RELATION TO THE WTO

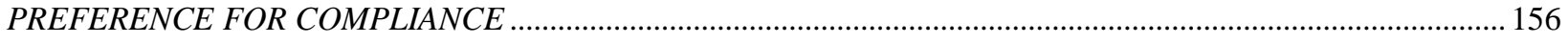

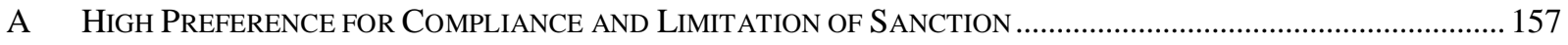

B A Non-Punitive LeVel of EnForcement Mechanism: the CurRent Design of Dispute SeTtLement

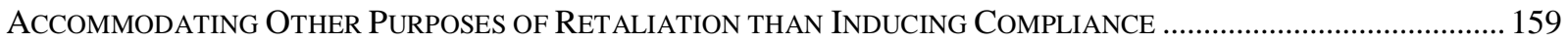

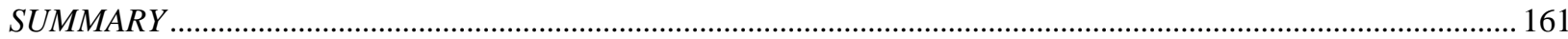

\section{CHAPTER FIVE}

RETALIATION TO INDUCE A MUTUALLY AGREEABLE SOLUTION: A POSITIVE SETTLEMENT

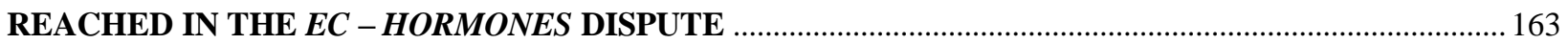

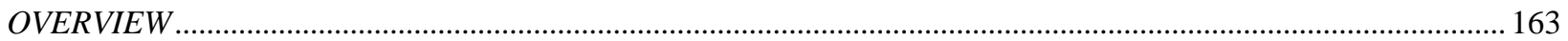

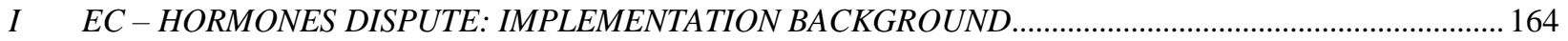

II RETALIATION TO INDUCE A MUTUALLY AGREEABLE SOLUTION AS ANOTHER COMPETING

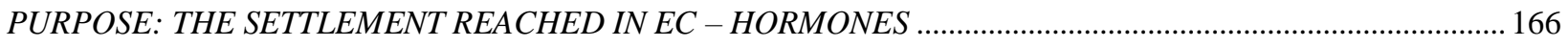

A Retaliation With the Purpose of Inducing a Mutually Agreeable Solution .............................. 168

B Retaliation Inducing a Mutually Agreeable Solution: Its Nature and Feature ....................... 170

C Retaliation Inducing a Mutually Agreeable Solution: A Defeat For the Winning Party? ...... 171

III ROOM FOR DEVIATION: THE QUESTION ABOUT THE EFFECTIVENESS OF WTO RETALIATION .... 174

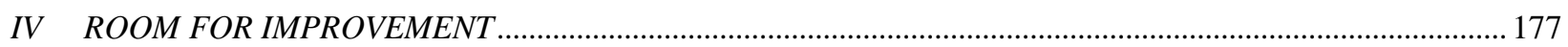

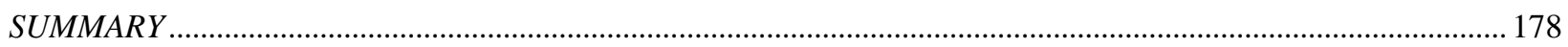


CHAPTER SIX

CONCLUSION

BIBLIOGRAPHY.. 


\section{LIST OF FIGURES}

Figure 1 comparison between remedies under public international law and under the WTO

Figure 2 Article 22.6 arbitrators' statements with regard to the purpose of retaliation

Figure 3 the multiple purposes of retaliation as achieved in practice 


\section{LIST OF ABBREVIATIONS}

$\mathrm{AB}$

$\mathrm{ACP}$

ACWL

BITs

CDSOA

DISC

DSB

DSU

EC

EU

FSC

GATS

GATT

GPA

ICJ

ILC

ITO

MFN

MOU

PCIJ

SCM

SCVPH

SPS

TBT

TRIPS

US

VCLT

WTO
Appellate Body

Africa, the Caribbean and the Pacific

Advisory Centre on WTO Law

Bilateral Investment Treaties

Continued Dumping and Subsidy Offset Act

Domestic International Sales Corporation

Dispute Settlement Body

Dispute Settlement Understanding

European Communities

European Union

Foreign Sales Corporations

General Agreement on Tariff in Services

General Agreement on Tariff and Trade

Agreement on Government Procurement

International Court of Justice

International Law Commission

International Trade Organisation

Most Favoured Nation

Memorandum of Understanding

Permanent Court of International Law

Subsidies and Countervailing Measures

Scientific Committee on Veterinary Measures relating to Public Health

Sanitary and Phytosanitary Measures

Technical Barriers to Trade

Trade-Related Aspects of Intellectual Property Rights

United States

Vienna Convention on Law and Treaties

World Trade Organization 


\begin{abstract}
The issue of non-compliance with the Dispute Settlement Body (DSB) recommendations and rulings emerges when the violator state fails to bring its inconsistent measures into conformity with its WTO obligations within a reasonable period of time. Compensation and suspension of concessions or other obligations (retaliation) are the only remedies provided under WTO law for cases of non-compliance. Many academic writings, as well as statements from WTO Members, have demonstrated pessimism concerning the effectiveness of these remedies, particularly retaliation.
\end{abstract}

The central point of this thesis concerns three main issues: the problems of WTO retaliation, the question of the effectiveness of retaliation, and the purposes of retaliation. This thesis aims to provide another perspective, besides the common "harm-resulted" perspective, for assessing the effectiveness of WTO retaliation. Accordingly, it provides several approaches: (1) identification of the purpose of retaliation in order to assess its effectiveness; (2) analysis of the enquiry whether there are in fact several purposes of WTO retaliation; (3) examination of the question whether the presence of retaliation purposes other than that inducing compliance is within the ambit of WTO law; (4) consideration of retaliation as a way of inducing a mutually agreeable solution; and (5) consideration of the question whether any deviation from strict compliance would undermine the WTO dispute settlement system.

On the basis of extensive research on the purposes of WTO retaliation, namely through interpreting Article 22 of the DSU, examining the design of WTO treaty, assessing the academic writings/debates as well as the statements of arbitrators; several conclusions are made, of which the main one is that inducing compliance is not the sole purpose that WTO retaliation can pursue. Therefore compliance is not the only benchmark by which the effectiveness of WTO retaliation should be measured. 


\section{CHAPTER ONE \\ INTRODUCTION TO WTO REMEDIES IN THE CASE OF NON- COMPLIANCE}

Consult before you legislate; Negotiate before you litigate; Compensate before you retaliate; And comply - at any rate (Hymn to Compliance). ${ }^{l}$

\section{Overview}

Pascal Lamy, the former EU Trade Commissioner and the current World Trade Organisation (WTO) Director-General, proposed this "Hymn to Compliance" in his speech to the United States Chamber of Commerce. It delineates the practical value of compliance amongst the WTO Members. Similarly, by establishing a dispute settlement scheme, WTO Members confirm that they are committed to their obligations under the WTO Agreement.

The WTO dispute settlement system sets up several rules and procedures that have to be followed to secure compliance. Parties are required first to request consultation when a dispute arises (consultation stage). If the consultation fails, the complaining party may request the establishment of a panel (adjudication stage). During this stage, if one of the parties is dissatisfied with the panel's decision, it may appeal to the Appellate Body. The panel/Appellate Body will issue a report that the Dispute Settlement Body (DSB) will adopt. After the adoption of the report, the DSB, a body for supervising the implementation of the report(s), requests the losing party bring itself into prompt compliance with WTO law or find mutually satisfactory adjustments (implementation stage). If the losing party fails to bring its measure into conformity within a reasonable period of time, the complaining party is entitled to resort to a temporary measure, either compensation or the suspension of the WTO obligations (retaliation) as the last resort (non-implementation stage).

\footnotetext{
${ }^{1}$ Pascal Lamy "Has International Capitalism Won the War and Lost the Peace?" (the US Chamber of Commerce, Washington DC, 8 March 2001).
} 
The questions are what happens if, even after retaliation is imposed, the violator state continues its violation measure? What should parties do when compliance cannot be achieved? What if the violator state continues the violation but at the same time provides compensation to the injured state? Does WTO law allow a continued violation as long as the violator state wants to bear compensation or suffer retaliation?

\section{Problem Presented}

The main problem of this thesis concentrates on the question of what the purpose(s) of retaliation is. The focus on this question aims to resolve the disagreements concerning the effectiveness of retaliation. Retaliation is generally believed to be a tool that has the effect of inducing the recalcitrant state to comply; therefore it is considered ineffective when it does little or nothing to induce compliance. This thesis provides a different approach and argues that to respond to the question whether or not WTO retaliation is an effective instrument, it is significant at first to determine the meaning or definition of effectiveness. With this intention, this thesis demonstrates that a rule or standard is deemed effective when it can achieve its purpose or objective.

The problem is that neither the DSU nor the WTO treaty provisions stipulate explicitly the purpose(s) of retaliation. Therefore, this thesis seeks to clarify this problem using methods such as interpreting Article 22 of the DSU, assessing the statements of Article 22.6 arbitrators as well as academic writings/debates.

This thesis also provides the assessments with respect to the design or structure of WTO treaty to sustain the searching of the purpose(s) of retaliation. These assessments provide an analysis with the reference to public international law and domestic law contract models. ${ }^{2}$ The objective of referring to other disciplines outside WTO law is made in order to provide other sources of guidance in assessing the main problems. As long as it is relevant, the reference to

\footnotetext{
${ }^{2}$ Because trade retaliation involves not only legal but also economic and politic aspects of the parties to the dispute; in this thesis, I do also make references to other related disciplines such as political science, political economy, international relations, and so forth.
} 
other disciplines is useful to provide a fuller picture. In practice, the panel and/or the Appellate Body have cited the decisions of the International Court of Justice to support their own decisions, ${ }^{3}$ and this practice has never been opposed by WTO Members. Therefore, the reference to other disciplines in this thesis is still appropriate. Finally, this thesis examines the question of the effectiveness of WTO retaliation in light of the purposes of retaliation that is identified throughout this extensive research.

\section{Introduction to WTO DSU Remedies: The Good Record of Compliance and the Temporary Remedies' Dilemma}

The WTO has its basis in the General Agreement on Tariff and Trade (GATT) 1947; and as the successor, it has established more comprehensive agreements and rules. One of these is the effective protection and enforcement system under dispute settlement.

The provisions that have governed dispute settlement since GATT 1947 are Articles XXII and XXIII of GATT. Although neither provision refers to the term "dispute settlement" nor provides a detailed procedure for disputes, they are the primary articles for dispute settlement. Article XXII contains the "consultation" provision, and Article XXIII provides the "nullification or impairment" rule. From these two "simple" articles, the current WTO dispute settlement system, embodied in the Understanding on Rules and Procedures Governing the Settlement of Disputes (DSU), has created the principles for the management of disputes. ${ }^{4}$

Irrespective of how innovative the system is, the central interest for parties to the dispute is whether the system provides finality and remedies under its regime. This perspective goes along with the Latin legal maxim, ubi jus ibi remedium (where there is a right, there is a

\footnotetext{
${ }^{3}$ For instance, the Appellate Body referred to the International Court of Justice decisions to support its finding on the generic term "natural resources" in Article XX(g) of GATT in the US - Shrimp dispute. See United States Import Prohibition of Certain Shrimp and Shrimp Products WTO DOC WT/DS58/AB/R (1998) at [footnote 109] (Report of the Appellate Body) [US - Shrimp (AB)].

${ }^{4}$ World Trade Organization Secretariat A Handbook on the WTO Dispute Settlement System: A WTO Secretariat Publication prepared for publication by the Legal Affairs Division and the Appellate Body (Cambridge University Press, 2004) at 12 [A Handbook on the WTO Dispute Settlement System]; the Dispute Settlement Understanding [the DSU], art 3.1.
} 
remedy). ${ }^{5}$ Hence a good dispute resolution system is one that offers certainty of legal rule and prompt and equal dispute procedures, as well as reasonable remedies.

The DSU provides two types of remedies for breaching WTO law: (a) final remedy (compliance by withdrawal or modification of measures that are inconsistent with WTO law); ${ }^{6}$ and (b) temporary remedies (compensation and suspension of concessions or other obligations, commonly referred as retaliation). ${ }^{7}$ The relationship existing between final and temporary remedies is hierarchical in nature, ${ }^{8}$ since Article 19 of the DSU clearly establishes the preference for prompt compliance with recommendations and rulings of the DSB (final remedy). Only when Members fail to withdraw or amend the WTO-inconsistent measures by the end of a reasonable period of time, does the DSU provide temporary remedies under Article 22.

\section{A Final Remedy's Good Record versus Temporary Remedies' Dilemmas}

As at April 2011, there have been 424 WTO complaints or consultation requests made pursuant to the DSU, including 248 disputes for which panels were established. ${ }^{9}$ Interestingly, to date there have been only nine disputes for which the arbitrations were established to assess the remedy for non-implementation. ${ }^{10}$ The few numbers of non-implementation disputes demonstrate that the respondent Members mostly comply with the recommendations and rulings adopted by the DSB. In other words, WTO final remedy (compliance) has a reasonably good record. $^{11}$

\footnotetext{
${ }^{5}$ Bryan A Garner (ed) Black's Law Dictionary (7th ed, West Group, 1999) at 1695.

${ }^{6}$ The DSU, arts 3.7 and 19.1 .

${ }^{7}$ Ibid, art 22.

8 John H Jackson "The WTO Dispute Settlement Understanding - Misunderstandings on the Nature of Legal Obligations (responding to Bello's article)" (1997) 91 Am J Int'L L 60 at 60-64 ["Misunderstandings on the Nature of Legal Obligations"]; Steve Charnovitz "The WTO's Problematic "Last Resort" against Noncompliance" (2002) 57(4) Aussenwirtschaft 409 at 411-412 ["Last Resort against Noncompliance"]; Allan Rosas "Implementation and Enforcement of WTO Dispute Settlement Findings: An EU Perspective” (2001) 4 JIEL 131 at 133-138.

${ }^{9}$ WTO Secretariat "Chronological List of Disputes Cases" <http://www.wto.org/english/tratop_e/dispu_e/dispu_status_e.htm>.

${ }^{10}$ Similar to the panel reports, there are several cases in which multiple arbitrators reports have been issued with regard to the same subject matters but brought by different states. For example, the United States and Canada brought similar complaints before the Article 22.6 arbitration proceeding regarding the EC - Hormones dispute, consequently there were two arbitrator reports being issued. For the efficiency reason, the same subject matter cases/reports are counted as one dispute in this thesis.

${ }^{11}$ Wilson states that in nearly 90 per cent of the cases that the panel and/or Appellate Body found to be WTO violations, the Member found in violation of its WTO obligations has indicated its intention to bring itself into 
In the non-compliance stage, the parties to a dispute have recourse to arbitration to resolve the disagreement between them. An arbitration body might be established under Articles 21 and 22 of the DSU. The arbitration under Article 21.5 of the DSU, also known as the compliance panel, is intended to resolve the question of compliance with the ruling and recommendation of the DSB. Additionally, arbitration under Article 22.6 of the DSU attempts to settle the level of retaliation and the possibility of suspending obligations under a different sector or agreement.

The DSB has authorised the request for retaliation in a number of disputes. Five disputes have been brought before the arbitration under Article 22.6 of the DSU; ${ }^{12}$ while the other four involve prohibited subsidies, therefore parties to the disputes have recourse to the arbitration under the DSU and the Subsidies and Countervailing Measures (SCM) Agreement. ${ }^{13}$

compliance and in most cases has already done so. See Bruce Wilson "Compliance by WTO Members with Adverse WTO Dispute Settlement Rulings: The Record to Date” (2007) 10(2) JIEL 397 at 398-399.

${ }^{12}$ European Communities - Regime for the Importation, Sale and Distribution of Bananas (United States) (Recourse to Arbitration by the European Communities under Article 22.6 of the DSU) WTO DOC WT/DS27/ARB (1999) (Decision by the Arbitrators) [EC - Bananas III (US) (Article 22.6-EC]; European Communities - Regime for the Importation, Sale and Distribution of Bananas (Ecuador) (Recourse to Arbitration by the European Communities under Article 22.6 of the DSU) WTO DOC WT/DS27/ARB/ECU (2000) (Decision by the Arbitrators) [EC Bananas III (Ecuador) (Article 22.6 - EC]; European Communities - Measures Concerning Meat and Meat Products (Hormones) (Canada)/(United States) (Recourse to Arbitration by the European Communities under Article 22.6 of the DSU) WTO DOC WT/DS48/ARB; WTO DOC WT/DS26/ARB (1999) (Decision by the Arbitrators) [EC - Hormones (Canada)/(US) (Article 22.6 - EC)]; United States - Anti Dumping Act of 1916 (Original Complaint by the European Communities) (Recourse to Arbitration by the United States under Article 22.6 of the DSU) WTO DOC WT/DS136/ARB, 24 February 2004 (Decision by the Arbitrators) [US - 1916 Act (Article 22.6 - US)]; United States - Continued Dumping and Subsidy Offset Act of 2000 (Recourse to Arbitration by the United States under Article 22.6 of the DSU) WTO DOC WT/DS217/ARB/BRA WT/DS234/ARB/CAN WT/DS217/ARB/CHL WT/DS217/ARB/EEC WT/DS217/ARB/IND WT/DS217/ARB/JAP, WT/DS217/ARB/KOR WT/DS234/ARB/MEX (2004) (Decision by the Arbitrator) [US - Byrd Amendment (Article 22.6 - US)]; United States - Measures Affecting the Cross-Border Supply of Gambling and Betting Services (Recourse to Arbitration by the United States under Article 22.6 of DSU) WTO DOC WT/DS285/ARB (2007) (Decision by the Arbitrator) [US-Gambling (Article 22.6-US)].

${ }^{13}$ Brazil - Export Financing Programme for Aircraft (Recourse to Arbitration by Brazil under Article 22.6 of the DSU and Article 4.11 of the SCM Agreement) WTO DOC WT/DS46/ARB (2000) (Decision by the Arbitrators) [Brazil - Aircraft (Article 22.6 - Brazil)]; United States - Tax Treatment for "Foreign Sales Corporations" (Recourse to Arbitration by the United States under Article 22.6 of the DSU and Article 4.11 of the SCM Agreement) WTO DOC WT/DS108/ARB (2002) (Decision of the Arbitrator) [US - FSC (Article 22.6 - US)]; Canada - Export Credits and Loan Guarantees for Regional Aircraft (Recourse to Arbitration by Canada under Article 22.6 of the DSU and Article 4.11 of the SCM Agreement) WTO DOC WT/DS222/ARB (2003) (Decision by the Arbitrator) [Canada - Aircraft II (Article 22.6 - Canada)]; United States - Subsidies on Upland Cotton (Recourse to Arbitration by the United States under Article 22.6 of the DSU and Article 4.11 of the SCM Agreement) WTO DOC WT/DS267/ARB/1 (2009) (Decision by the Arbitrator) [US - Upland Cotton (Article 22.6 - US)]. 
The primary remedy is a general recommendation for the respondent party to comply; while compensation and retaliation are the remedies for eventual non-compliance. ${ }^{14}$ Instead of being praised, remedies under Article 22 (compensation and retaliation) are often criticised by various commentators and they are also viewed as ineffective by many Members, especially those from developing and least-developed countries.

Compensation, usually in the form of trade compensation, ${ }^{15}$ has been agreed between disputing parties in relatively few cases. ${ }^{16}$ The rationale for this less attractive option lies in the words of "developing mutually acceptable compensation" and "shall be consistent with covered agreements". ${ }^{17}$ Both of these phrases suggest that instead of being an automatic obligation of respondent states, compensation is voluntary and should be consistent with the principle of nondiscrimination obligations under Article I:1 of the GATT 1994. Moreover, from the complainant's point of view, particularly concerning industry, compensation (lower barriers in the other areas) does nothing to eliminate non-compliance in the area subjected to the dispute. On the contrary, the respondent faces a difficulty volunteering a sector of the economy for increased foreign competition to protect another sector that is benefiting from the violation. ${ }^{18}$ Thus, parties in dispute often neglect compensation remedy and directly request authorisation to retaliate.

\footnotetext{
${ }^{14}$ Robert E Hudec "Broadening the Scope of Remedies in WTO Dispute Settlement" in Friedl Weiss (ed) Improving WTO Dispute Settlement Procedures: Issues and Lesson from the Practice of Other International Courts and Tribunals (Cameron May, 2000) 369 ["Broadening the Scope of Remedies"].

${ }^{15}$ In the US - Copyright case, financial compensation, as another form of compensation, is granted on bilateral basis.

${ }^{16}$ For example, Japan - Taxes on Alcoholic Beverages - Mutually Acceptable Solution on Modalities for Implementation WTO DOC WT/DS8/20 WT/DS10/20 WT/DS11/18 (1998); Turkey - Restrictions on Imports of Textile and Clothing Products - Notification of Mutually Acceptable Solution WTO DOC WT/DS34/14 (2001); United Sates - Definitive Safeguard Measures on Imports of Circular Welded Carbon Quality Line Pipe from Korea - Agreement under Article 21.3(b) of the DSU WTO DOC WT/DS202/18 (2002); United States - Section 110(5) of the US Copyright Act - Notification of a Mutually Satisfactory Temporary Arrangement WTO DOC WT/DS160/23 (2003). In the first three cases (Japan - Alcoholic Beverages, Turkey - Textile, US - Line Pipe), both parties reached agreement concerning trade compensation; however, in the last dispute (US - Copyright), the compensation was agreed in the form of financial compensation. See also William J Davey "Compliance Problems in WTO Dispute Settlement" (2009) 42 Cornell Int'l L J 119 at 122.

${ }^{17}$ The DSU, arts 22.1 and 22.2.

${ }^{18}$ David Palmeter and Petros C Mavroidis Dispute Settlement in the World Trade Organization: Practice and Procedure (2nd ed, Cambridge University Press, 2004) at 266.
} 
If, within 20 days after the expiry of the reasonable period of time, the parties fail to agree on satisfactory compensation, the complainant party may request permission to retaliate from the DSB. ${ }^{19}$ Retaliation under the DSU is in the form of suspension of concessions or other obligations. ${ }^{20}$ The DSU provides several requirements for retaliation. One of these requirements is that it should be imposed in the same sector as that in which the violation was found. ${ }^{21}$ Nonetheless, the complainant may request the authorisation to retaliate in the other sectors or agreements (cross retaliation) if the complainant considers it impracticable or ineffective to retaliate in the same sector. ${ }^{22}$ Retaliation applies on a discriminatory basis against the Member that fails to implement the recommendations or rulings. It is applied selectively by one Member against another (bilateral basis), nevertheless it requires the DSB's approval (multilateral basis). ${ }^{23}$

Many commentators perceive retaliation as having significant flaws. Bronckers and van den Broek, for instance, state that retaliation offers no relief to those actually damaged, puts inappropriate burden on innocent bystanders, and offers no appropriate relief to the injured party suffering as a result of the violator state's regime. ${ }^{24}$ Retaliation may also result in market distortion and welfare loss, which in the end may cultivate political resentment and provoke a political debacle. ${ }^{25}$ Moreover, this scheme allows Members to fight protectionism with protectionism $^{26}$ and tends to punish consumers in the victim state and exporters in the violator state for the misdeeds of protectionists in the violator state, while leaving the protectionist that initiated the violation largely unaffected. ${ }^{27}$ Although the application of retaliation is under multilateral surveillance by the DSB, the tit-for-tat WTO retaliation tends to undermine cross-

\footnotetext{
${ }^{19}$ The DSU, art 22.2.

${ }^{20}$ Ibid, art 22.

${ }^{21}$ Ibid, art 22.3.

22 Ibid.

${ }^{23}$ A Handbook on the WTO Dispute Settlement System, above n 4, at 81.

${ }^{24}$ Marco Bronckers and Naboth van den Broek "Financial Compensation in the WTO: Improving the Remedies of WTO Dispute Settlement" (2005) 8(1) JIEL 101 at 103.

${ }^{25}$ Sungjoon Cho "The Nature of Remedies in International Trade Law" (2004) 65 U Pitt L Rev 763 at 785.

${ }^{26}$ Steve Charnovitz "Should the Teeth be Pulled?: An Analysis of WTO Sanctions" in Daniel L M Kennedy and James D Southwick (eds) Political Economy of International Trade Law: Essays in Honor of Robert E. Hudec (Cambridge University Press, 2002) 602 at 622 ["Should the Teeth be Pulled?"].

${ }^{27}$ Jide Nzelibe "The Case against Reforming the WTO Enforcement Mechanism” (2008) U Ill L R 319 at 325.
} 
border economic integration as well as the security and predictability of the multilateral trading system of the WTO Agreement. ${ }^{28}$

\section{B Other Dilemmas Resulting from the Implementation of Retaliation: Lessons from the Disputes}

As pointed out by Malacrida, there have been 28 requests for authorisation to retaliate concerning 16 different disputes since the DSU entered into force in 1995 until January $2008 .^{29}$ These 28 requests were filed by 13 different Members, nine of which were developing country Members. ${ }^{30}$ The complaining states obtained an authorisation to impose retaliatory action from the DSB in nine different disputes. ${ }^{31}$ However, so far, retaliation measures have been imposed only in four different disputes: EC - Bananas III (the United States against the European Communities), EC - Hormones (the United States and Canada against the European Communities), US - FSC (the European Communities against the United States) and US - Byrd Amendment (the European Communities, Japan and Mexico against the United States). ${ }^{32}$ Even though the number of retaliation disputes is insubstantial, these disputes arguably raise several issues that might challenge the efficacy of WTO retaliation, as follows.

$1 \quad$ The ability of developing countries to impose retaliatory measures

The issue of the ability of developing countries to impose retaliatory measures emerged in EC - Bananas III (Ecuador) for the first time. The dispute stems from the European Communities banana regime that provided for duty-free importing of bananas originating from the European Communities former colonies in Africa, the Caribbean and the Pacific (ACP)

\footnotetext{
${ }^{28}$ Reto Malacrida "Toward Sounder and Fairer WTO Retaliation: Suggestions for Possible Additional Procedural Rules Governing Members' Preparation and Adoption of Retaliation Measures” (2008) 42(1) JWT 3 at 11-16.

${ }^{29}$ Ibid, at 6, 56-60.

${ }^{30}$ Ibid, at 7 .

${ }^{31}$ EC - Bananas III (US and Ecuador) (Article 22.6 - EC), above n 12; EC-Hormones (US and Canada) (Article 22.6-EC), above n 12; Brazil - Aircraft (Article 22.6-Brazil), above n 13; US - FSC (Article 22.6 - US), above n 13; Canada - Aircraft II (Article 22.6 - Canada), above n 13; US - 1916 Act (Article 22.6 - US) above n 12; US Byrd Amendment (Article 22.6 - US), above n 12; US - Gambling (Article 22.6 - US), above n 12; US - Upland Cotton (Article 22.6-US), above n 13.

${ }^{32}$ Malacrida, above n 28, at 7.
} 
regions. ${ }^{33}$ The WTO panel and Appellate Body concluded that the European Communities bananas regime was inconsistent with obligations under the GATT, GATS, and the Agreement on Import Licensing Procedures. The European Communities subsequently attempted to revise its regime $;^{34}$ however, both the United States and Ecuador claimed that the revised regulation continued to violate WTO obligations.

The United States directly requested for the suspension of concessions under Article 22.2 of the DSU. ${ }^{35}$ Ecuador requested a compliance panel under Article 21.5 of the DSU. ${ }^{36}$ In the end, both the United States and Ecuador obtained authorisation to retaliate; in fact, only the United States enforced the retaliatory measures. Ecuador, considering the harm of retaliation under the same sector or agreement, requested and obtained authorisation to suspend TRIPS obligations (cross-retaliation). ${ }^{37}$ Nevertheless Ecuador did not implement this authorised retaliatory measure. The arbitration panel itself provided a lengthy note on the political, practical and legal problems that can emerge with regard to the imposition of cross-retaliation. ${ }^{38}$ In general for developing countries such as Ecuador utilising retaliation against more economically powerful states would impair their trade, or in other words, they would economically "shoot [themselves] in the foot". 39

\footnotetext{
${ }^{33}$ Regulation 404/93 of 13 February 1993 on the Common Organization of the Market in Bananas [1993] OJ L 047.

${ }^{34}$ For example by introducing Regulation 1637/98 of 20 July 1998 amending Regulation 404/93 on the common organization of the market in bananas [1998] OJ L 210.

${ }^{35}$ European Communities - Regime for the Importation, Sale and Distribution of Bananas (Recourse by the United States to Article 22.2 of the DSU) WTO DOC WT/DS27/43 (1999) (Award of the Arbitrator).

${ }^{36}$ European Communities - Regime for the Importation, Sale and Distribution of Bananas (Recourse to Article 21.5 of the DSU by Ecuador) WTO DOC WT/DS27/RW/ECU (1999) (Report of the Panel) [EC - Bananas III (Article 21.5 - Ecuador) (panel)].

${ }^{37}$ The complainant may request an authorisation to retaliate under other sectors or agreements (cross-retaliation) if the complainant finds that retaliation in the same sector is impracticable or ineffective. Article 22.3 of the DSU provides the procedures and principles regarding cross-retaliation. The principles of cross-retaliation will be explained further in chapter two.

${ }^{38}$ EC-Bananas III (Article 21.5 - Ecuador) (panel), above n 36, at [130]-[165].

39 Nsongurua J Udombana "A Question of Justice: the WTO, Africa, and Countermeasures for Breaches of International Trade Obligations" (2005) 38 J Marshall L Rev 1153 at 1185-1186; Bryan Mercurio "Improving Dispute Settlement in the World Trade Organization: The Dispute Settlement Understanding Review - Making It Work?" (2004) 38(5) JWT 795 at 840 ["Improving Dispute Settlement in the WTO"]; Bronckers and van den Broek, above $\mathrm{n} 24$, at 104.
} 
The possibility of trade wars is evidenced from a case between two powerful developed states in the US - FSC dispute. In 1984, the United States Congress passed Foreign Sales Corporations (FSC) legislation to resolve the long-standing dispute under GATT over the predecessor legislation, which was the Domestic International Sales Corporation (DISC). ${ }^{40}$ Due to the fact that the European Communities had not complained about the FSC being inconsistent with the GATT law since 1985, it was surprising when the European Communities later challenged this legislation before a WTO panel. ${ }^{41}$ Based on the general assumption that it would be impossible for the United States to terminate the FSC subsidy because many important industries were benefiting from it, the most likely explanation for the European Communities' action was that they were using the FSC dispute to overcome the United States overaggressiveness (the adoption of carousel retaliation) in the EC-Hormones and EC-Bananas III disputes. $^{42}$

\section{$3 \quad$ The issue of termination of retaliatory measures}

The issue of termination of retaliatory measures (post-retaliation) emerged in $E C-$ Hormones. It is a long-disputed case between the European Communities, the United States and Canada concerning hormone-treated beef. Although the panel and Appellate Body have resolved this dispute, another disagreement emerged on how to implement and comply with the recommendations and rulings of the DSB. The European Communities claimed that they have already brought their inconsistent measures into compliance; however, the United States and Canada rejected this claim. The European Communities, infuriated with the continuance of the sanctions, have initiated another dispute settlement proceeding against Canada and the United

\footnotetext{
${ }^{40}$ C O'Neal Taylor "Impossible Cases: Lessons from the First Decade of WTO Dispute Settlement" (2007) 28 U Pa J Int'l Econ L 309 at 405.

${ }^{41}$ Robert E Hudec "Industrial Subsidies: Tax Treatment of "Foreign Sales Corporation"” in Ernst-Ulrich Petersmann and Mark A Pollack (eds) Transatlantic Economic Dispute: the EU, the US and the WTO (Oxford University Press, 2003) 175 at 180.

${ }^{42}$ Ibid, at 181 .
} 
States seeking their removal. ${ }^{43}$ The $E C$ - Hormones dispute is one good example of the postretaliation problem. Even though the arbitration imposes certain limitations and determines the level of retaliation, when complainant states impose retaliatory measures, there are no assurances as to when and how they should be terminated.

\section{$4 \quad$ Continued non-implementation or procedural delay}

The efficacy of WTO retaliation is questionable when the inconsistent measures interact with a domestic politically sensitive issue. The difficulty encountered by the United States administration in US - Byrd Amendment is a good example. The Continued Dumping and Subsidy Offset Act (CDSOA), also known as the Byrd Amendment, named after Senator Robert Byrd of West Virginia who sponsored it, was enacted as a part of the Agricultural, Rural Development, Food and Drug Administration, and Related Agencies Appropriation Act. ${ }^{44}$ The CDSOA mandates the distribution of the collected antidumping and countervailing duties to the United States affected producers that brought and supported complaints about foreign producers. ${ }^{45}$ Although the Clinton administration requested Congress to revisit and to repeal the CDSOA, Congress passed the legislation to neutralise actionable subsidies in order to preserve jobs that might otherwise be destroyed. ${ }^{46}$ Thus, despite its controversy, this legislation is popular in the United States senate and amongst domestic producers, especially the United States steel industry that has obtained benefits from it. It is unsurprising that it took many years for the United Stated to comply fully with the ruling, despite the fact that the European Communities and Mexico (the complainants in this case) imposed the retaliatory measures and indicated that their retaliatory measures will remain in place as long as the United States maintains the inconsistent measures. $^{47}$

43 United States - Continued Suspension of Obligations in the EC - Hormones Dispute WTO DOC WT/DS320/AB/R (2008) (Report of the Appellate Body); Canada - Continued Suspension of Obligations in the EC - Hormones Dispute WTO DOC WT/DS321/AB/R (2008) (Report of the Appellate Body).

${ }^{44}$ Public Law 106-387, 19 CFR § 159.61 (2000) [US Public Law 106-387].

${ }^{45}$ Simone Hartmann-Tröger "Antidumping and Countervailing Duties: the Byrd Amendment" (2008) 11 Int'l Trade \& Bus L Rev 287 at 288.

${ }^{46}$ Ibid, at 289.

${ }^{47}$ Ibid, at 298. 
In summary, although there is a positive record of Members complying with the adverse rulings, there are also a small number of non-implementation cases in WTO dispute settlement. In the cases of non-implementation, the DSU provides two remedies which are compensation and retaliation. Nonetheless these two remedies, particularly retaliation, have been perceived to suffer from several problems. This is why the study in this thesis is important. It does not look at the quantity of the disputes but the quality of these remedies, in particular retaliation, to sustain the WTO dispute settlement system.

Part II of this chapter elaborated on these problems and dilemmas. The subsequent part provides the views from scholars, commentators, practitioners and WTO Members concerning some related issues which are the areas of discussion in this thesis.

\section{Overview of Literature on the Effectiveness of WTO Remedies, the Purpose(s) of Retaliation, WTO Law in Relation to Other Regimes, and Option to Improve Remedies}

The purpose of this section is to describe the area of study or research in this thesis, as well as to outline several views and perspectives from scholars, practitioners, commentators and WTO Members with regard to the areas of study in this thesis. This section is divided into four main parts: (a) the effectiveness of WTO remedies; (b) the purpose(s) of retaliation; (c) WTO law in relation to other regimes; and (d) options to improve remedies.

\section{A The Effectiveness of WTO Remedies}

While some observers or commentators have a positive view of the effectiveness of WTO dispute settlement, ${ }^{48}$ they share a similar perspective that the effectiveness of the DSU temporary remedies, especially retaliation, is questionable. ${ }^{49}$ Debra Steger boldly states that reform in WTO

\footnotetext{
${ }^{48}$ For example, Davey notes that since its establishment, the WTO dispute settlement system has worked reasonably well in providing an effective mechanism through which WTO Members are able to resolve disputes. See William J Davey "The WTO Dispute Settlement System: The First Ten Years" (2005) 8 JIEL 17 at 50.

${ }^{49}$ Nzelibe, above n 27, at 321, 327-328; Bronckers and van den Broek, above n 24; Cho, above n 25, at 785-790; Brendan P McGivern "Seeking Compliance with WTO Rulings: Theory, Practice and Alternative" (2002) 36(1) The 
dispute settlement is not needed, since the system can be improved through practices; it is on the area of implementation that most of the Members' attention should be focused. ${ }^{50}$ Moreover, she states that retaliation is a blunt instrument that only powerful countries can use effectively. ${ }^{51}$ Mercurio shares a similar view with Steger by providing three reasons why retaliation is an imperfect means of obtaining compliance. The first reason is that retaliation does nothing when the measure is too politically sensitive to be removed. The second reason is that a large suspension is self-destructive, and the last reason is that developing countries cannot utilise it against powerful developed countries. ${ }^{52}$

Additionally, many Members seem to agree that the implementation phase of the dispute settlement system is relatively weak compared with other phases. ${ }^{53}$ Mexico, for example, observed that "the main weakness of the [DSU] was the excessive length of time that a Member could maintain a measure which had been found to be WTO-inconsistent without any consequences." ${ }^{54}$ There are four main proposals put forward by Mexico to deal with the remedies problem: early determination of nullification or impairment, retroactive determination, preventive measures, and negotiable remedies. ${ }^{55}$

My thesis takes a different approach in responding to the question of the effectiveness of WTO retaliation. It suggests identifying first what "effective" means. The definition of effectiveness is discussed in more detail in chapter three below. However, in short, something is effective if it can achieve its purpose or objective. Consequently, to respond to the question of whether retaliation is effective or not, it is significant to identify the purposes of retaliation.

Int'l Lawyer 141 at 152-153; Bernard O'Connor "Remedies in the World Trade Organization Dispute Settlement System - The Bananas and Hormones Cases" (2004) 38(2) JWT 245 at 257-260; Malacrida, above n 28, at 17-27.

${ }^{50}$ Debra P Steger "Commentary on the Doha Round: Institutional Issue" (2005) 5(4) Global Econ J 1 at 4-5. McRae also states that remedies and sanctions are the areas in WTO dispute settlement that need improvement. See Donald McRae "Measuring the Effectiveness of the WTO Dispute Settlement System" (2008) 3(1) AJWH 1 at 18.

${ }^{51}$ Ibid.

${ }^{52}$ Mercurio "Improving Dispute Settlement in the WTO", above n 39, at 840.

${ }^{53}$ Edwini Kessie "The 'Early Harvest Negotiation' in 2003" in Federico Ortino and Ernst-Ulrich Petersmann (eds) The WTO Dispute Settlement System 1995-2005 (Kluwer Law International, 2004) 115 at 142.

${ }^{54}$ Dispute Settlement Body Special Session Minutes of Meeting - Held in the Centre William Rappard on 13 - 15 November 2002 WTO DOC TN/DS/M/6 (31 March 2003) at 5.

${ }^{55}$ Dispute Settlement Body Special Session Amendments to the Understanding Rules and Procedures Governing the Settlement of Disputes Proposed Text by Mexico - Communication by Mexico WTO DOC TN/DS/W/40 (27 January 2003). 


\section{B The Purpose(s) of Retaliation}

It is necessary to identify the purpose that retaliation might serve. The arbitrators in $U S$ Byrd Amendment (Article 22.6 - US) stated that "a large part of the conceptual debate [suspension of obligations in the DSU] that took place in these proceedings could have been avoided if a clear 'object and purpose' were identified." ${ }^{, 56}$ Put differently, regardless of any modifications or reform proposals proposed, without a clear objective or purpose the arbitrators and Members still have uncertain direction in resolving the retaliation problems.

Furthermore this thesis argues that identifying the purpose is significant in determining or measuring the degree of the effectiveness. As a result, one should determine the purpose or the objective of a rule or standard first in order to determine the effectiveness of that rule or standard. The subsequent part elaborates on several issues with respect to the purpose(s) of WTO retaliation.

\section{$1 \quad$ The lack of clarity of article 22: various alleged purposes emerge}

While the DSU clearly specifies that the aim of WTO dispute settlement is to provide security and predictability to the multilateral trading system, ${ }^{57}$ the purpose(s) of retaliation is unclear. The DSU does not stipulate explicitly the purpose(s) of retaliation under Article $22 .{ }^{58}$ However by referring to arbitrators' findings ${ }^{59}$ and some academics' views, ${ }^{60}$ there are several purposes that retaliation may pursue. They are: (a) inducing compliance; ${ }^{61}$ (b) providing

\footnotetext{
${ }^{56}$ US - Byrd Amendment (Article 22.6 - US), above n 12, at [6.4] (emphasis added).

${ }^{57}$ The DSU, art 3.2. See also John H Jackson "International Law Status of WTO Dispute Settlement Reports: Obligation to Comply or Option to "Buy Out"” (2004) 98 Am J Int'l L 109 at 111-114 ["Obligation to Comply or to Buy Out"].

${ }^{58}$ Arbitrators in US - Byrd Amendment stated that "it is not completely clear what role is to be played by the suspension of obligations in the DSU...". See US - Byrd Amendment (Article 22.6 - US), above n 12, at [6.4].

${ }^{59}$ For instance, EC - Bananas III (US) (Article 22.6-EC), above n 12, at [6.3]; US - Byrd Amendment (Article 22.6 - US), above n 12, at [6.3].

${ }^{60}$ For instance, Joost Pauwelyn "Calculation and Design of Trade Retaliation in Context: What is the Goal of Suspending WTO Obligations?" in Chad P Bown and Joost Pauwelyn (eds) The Law, Economic and Politics of Retaliation in WTO Dispute Settlement (Cambridge University Press, 2010) 34 at 36-38 ("Calculation and Design of Trade Retaliation"); Alan O Sykes "Comment on Chapter 2" in Chad P Bown and Joost Pauwelyn (eds) The Law, Economic and Politics of Retaliation in WTO Dispute Settlement (Cambridge University Press, 2010) 70 at 70-72.

${ }^{61}$ EC - Bananas III (US) (Article 22.6 - EC), above n 12, at [6.3]; US - Gambling (Article 22.6 - US), above n 12, at [4.112].
} 
compensation; ${ }^{62}$ (c) rebalancing; ${ }^{63}$ and (d) "deterring inefficient breach but encouraging efficient breaches". 64

(a) Inducing compliance

Inducing compliance was stated as a purpose for the first time by the arbitrators in $E C-$ Bananas III (US) (Article 22.6 - EC) and it was reiterated in subsequent cases except in US 1916 Act (Article 22.6 - US) and US - Byrd Amendment (Article 22.6 - US). In EC-Banana III (US) (Article $22.6-E C$ ), the arbitrators agreed with the United States argument that the temporary nature of compensation and suspension of concession indicates that the purpose of countermeasures is to induce compliance. ${ }^{65}$ In Brazil - Aircraft (Article 22.6 - Brazil), the arbitrators explained the appropriateness of countermeasures "if it effectively induces compliance". 66 The arbitrators even authorised punitive suspension on the basis of inducing compliance in the US - FSC (Article 22.6 - US) and Canada - Aircraft II (Article 22.6 Canada) disputes. ${ }^{67}$ Finally in US - Gambling (Article 22.6 - US), the arbitrators interpreted the meaning of the criteria of effectiveness in order to authorise the right of cross-retaliation. ${ }^{68}$ They cited the conclusion of the arbitrator in EC - Banana III (Ecuador) (Article 22.6-EC) that "the effective criterion empowers the party seeking suspension to ensure that the impact of that suspension is strong and has the desired result, namely to induce compliance". ${ }^{69}$

\footnotetext{
${ }^{62}$ US - Byrd Amendment (Article 22.6 - US), above n 12, at [6.3].

${ }^{63}$ David Palmeter and Stanimir Alexandrov “" "Inducing Compliance” in WTO Dispute Settlement” in Daniel L M Kennedy and James D Southwick (eds) The Political Economic of International Trade Law (Cambridge University Press, 2002) 646 at 647.

${ }^{64}$ Warren F Schwartz and Alan O Sykes "The Economic Structure of Renegotiation and Dispute Resolution in the World Trade Organization” (2002) 31 J Legal Stud S179 at S183.

${ }^{65}$ EC-Bananas III (US) (Article 22.6-EC), above n 12, at [6.3].

${ }^{66}$ Brazil-Aircraft (Article 22.6-Brazil), above n 13, at [3.44].

${ }^{67}$ Canada-Aircraft (Article 22.6 - Canada), above n 13, at [3.121]; US - FSC (Article 22.6 - US), above n 13, at [5.52]-[5.57], [6.2].

${ }^{68}$ US - Gambling (Article 22.6 - US), above n 12, at [4.29].

${ }^{69}$ Ibid, at [4.29] and [4. 84].
} 


\section{(b) Compensation}

The arbitrators started to consider that WTO retaliation might also have other purposes in US - 1916 Act (Article 22.6 - US). ${ }^{70}$ Furthermore in US - Byrd Amendment (Article 22.6 - US), while noting that the concept of inducing compliance has been referred to in past arbitrations, the arbitrators stated that "it is not expressly referred to in any part of the DSU" and that they "are not persuaded that the object and purpose of the DSU would be exclusively to induce compliance." 71 While the arbitrators did not "exclude that inducing compliance is part of the objectives behind suspension," they said that "at most it can be only one of a number of purposes in authorising the suspension of concession or other obligations." ${ }^{, 72}$ Furthermore, the arbitrators concluded that "... [the requirement of equivalent levels] seems to imply that suspension of concessions or other obligations is only a means of obtaining some form of temporary compensation, even when the negotiation of compensations has failed."73 In other words, the arbitrators implied that the purpose of retaliation is to provide compensation.

\section{(c) Rebalancing}

Sebastian writes that given that the WTO Agreements emerged from negotiations conducted under the basis of reciprocity, it is often argued that the purpose of retaliation is to rebalance this bargain. ${ }^{74}$ Commentators who support the purpose of rebalancing, for instance, are Palmeter and Alexandrov. They argue that: ${ }^{75}$

[The inducing compliance] doctrine is legally in error and is unwise from a policy perspective. The purpose of countermeasures in the WTO is not to induce compliance, but to maintain the balance of reciprocal trade concessions negotiated in the WTO agreements.

\footnotetext{
${ }^{70} U S-1916$ Act (Article 22.6 - US), above n 12, at [5.3].

${ }^{71}$ US - Byrd Amendment (Article 22.6 - US), above n 12, at [3.74].

${ }^{72}$ Ibid, at [3.74].

${ }^{73}$ Ibid, at [6.3] (emphasis added).

74 Thomas Sebastian "World Trade Organization Remedies and the Assessment of Proportionality: Equivalence and Appropriateness” (2007) 48 Harv Int'l L J 337 at 370.

${ }^{75}$ Palmeter and Alexandrov, above n 63, at 647 (emphasis added).
} 
Moreover, another commentator, Lawrence, does not argue against the purpose of inducing compliance directly. However, he admits that WTO remedies can achieve several purposes simultaneously; and "the goal achieved most precisely is maintaining reciprocity."

(d) "To deter inefficient breach but to encourage efficient breach"

Schwartz and Sykes also take part in the retaliation purpose debate by developing a theory from political (public choice) and economic contracts perspectives. They suggest that WTO agreements are incomplete contracts amongst political actors and the metric of welfare for each signatory will not be money but the political welfare of its political officials. ${ }^{77}$ Therefore, when the cost of political performance exceeds the benefit of performance (politically costly), the DSU allows a violator to continue a violation, as long as it compensates or is willing to bear the costs of the retaliation ("to encourage efficient breach"). In Schwartz and Sykes's view, formal sanction is not needed to induce a high level of compliance, owing to domestic pressures for compliance, reputational penalties, and unilateral sanctions that put pressure on parties to respect their commitments (to deter inefficient breach). ${ }^{78}$ Thus, they conclude, the function of retaliation is "to deter inefficient breaches but to encourage efficient breaches".

\section{$2 \quad$ Two schools of thought disagreements}

The four arguable purposes, which are previously explained, can be categorised into two main schools of thought: inducing compliance and rebalancing. ${ }^{79}$ The battle between these schools of thought has a strong correlation with the previous debate between Judith Bello and John Jackson. In 1996, Bello wrote an article in the American Journal of International Law, ${ }^{80}$ which stated that: ${ }^{81}$

\footnotetext{
${ }^{76}$ Robert Z Lawrence Crimes \& Punishments? Retaliation under the WTO (Institute for International Economics, 2003) at 47.

${ }^{77}$ Schwartz and Sykes, above n 64, at S184-S185.

${ }^{78}$ Ibid, at S204.

${ }^{79}$ Both compensation and "to deter inefficient breach but to encourage efficient breach" arguments have the features of rebalancing. For efficiency reason, I put them together for the purpose of rebalancing.

${ }^{80}$ Judith Bello “The WTO Dispute Settlement Understanding: Less is More" (1996) 90 Am J Int'l L 416.

${ }^{81}$ Ibid, at 416-417 (emphasis added).
} 
Like the GATT rules...the WTO rules are simply not "binding" in the traditional sense...there is no prospect incarceration, injunctive relief, damages for harm inflicted or police enforcement. The WTO has no jailhouse, no bail bondsmen, no blue helmets, no truncheons or tear gas. Rather, the WTO...relies upon voluntary compliance.

She also suggested that compliance with the WTO remains optional; a Member has three choices when its measures are challenged. First, it may comply with the ruling. Second, it may maintain inconsistent measures but provide a compensatory benefit to restore the balance of negotiated concessions. Third, it may choose to maintain the inconsistent measure and suffer retaliation for the purpose of rebalancing. Thus, she concludes that the only truly binding WTO obligation is to maintain the balance of concessions negotiated amongst Members. ${ }^{82}$

Jackson subsequently inserted a rebuttal in the same journal and argued that: ${ }^{83}$ ....an adopted dispute settlement report establishes an international law obligation upon the member in question to change its practice to make it consistent with the rules of the WTO Agreement and its annexes...Thus, the DSU clearly establishes a preference for an obligation to perform...Certainly they [WTO rules] are binding in the traditional international law sense.

Even though many legal scholars and commentators support Jackson's view on compliance, ${ }^{84}$ others, particularly economists, seem to disagree with a purpose of strict compliance and support Bello's arguments on a purpose of rebalancing. ${ }^{85}$

\footnotetext{
${ }^{82}$ Ibid, at 417-418.

${ }^{83}$ Jackson "Misunderstandings on the Nature of Legal Obligations", above n 8, at 60, 63 (emphasis added).

${ }^{84}$ For example Andrew Mitchell states that the suspension of concessions is indeed to induce compliance. See Andrew D Mitchell "Proportionality and Remedies in WTO Disputes" (2006) 17 EJIL 985 at 999 ["Proportionality and Remedies in WTO Disputes"]; Charnovitz "Should the Teeth be Pulled?", above n 26, at 603; Joost Pauwelyn "Enforcement and Countermeasures in the WTO: Rules are Rules - Toward a More Collective Approach" (2000) 94 Am J Int'l L 335 at 343 ["Enforcement and Countermeasures"].

${ }^{85}$ Lawrence, above n 76, at 47; Schwartz and Sykes, above n 64; Kyle Bagwell "Remedies in the WTO: An Economic Perspective" Columbia University Department of Economics Discussion Paper No: 0607-09, January 2007 at $7-11$.
} 
Additionally, the doubt over the purposes of retaliation has been reflected in practice. This is confirmed by the changes of the United States view and arbitrators' decisions regarding the purposes of retaliation. The United States, at first in the EC-Bananas III dispute, strongly supported the purpose of inducing compliance by stating that: ${ }^{86}$

The suspension of concessions under Article 22 was an essential element of an important objective of the DSU, namely compliance with the WTO rules. The arbitrators had recognised this and had agreed that the purpose of countermeasures was to induce compliance.

However, afterwards in the US - Byrd Amendment dispute, the United States appeared to reverse its stand point by stating that "[t]he United States also welcomed the Arbitrators' rejection of the argument that the 'ultimate goal' of the suspension of concessions or other obligations was to 'induce compliance'."87 The uncertainty also appears in arbitrators' statements. Though at first in EC - Banana III (US) (Article 22.6 - EC) they stated that the purpose of countermeasures is to induce compliance; in US - Byrd Amendment (Article 22.6 $U S)$, they showed uncertainty with their previous position by giving these two statements. First, they are not persuaded that the object and purpose of the DSU would be exclusively to induce compliance, and second they stated that it is not completely clear what role is to be played by the suspension of obligations in the DSU. ${ }^{88}$

In short, regardless of the disagreements amongst the observers or commentators, they actually promote the notion of single purpose of retaliation: either inducing compliance or rebalancing. Likewise, in most Article 22.6 arbitral proceedings, the arbitrators have endorsed a single purpose of retaliation, namely inducing compliance. Chapter three below examines further the purpose(s) of retaliation.

\footnotetext{
${ }^{86}$ Dispute Settlement Body Minutes of Meeting - Held in the Centre William Rappard on 19 April 1999 WTO DOC WT/DSB/M/59 at 1-2 (3 June 1999) (statement by the United States).

${ }^{87}$ Dispute Settlement Body Minutes of Meeting - Held in the Centre William Rappard on 24-26 November 2004 WTO DOC WT/DSB/M/178 at 73 (17 January 2005) (statement by the United States) (emphasis added). ${ }^{88}$ US - Byrd Amendment (Article 22.6 - US), above n 12, at [3.73], [6.4].
} 

purpose $(s)$ ?

The DSU provides "equivalent to the level of nullification or impairment" as a ceiling for the level of suspension. ${ }^{89}$ The equivalent requirement appears to provide a limitation to the level of suspension stipulated under Article XXIII:2 of GATT $^{90}$ and Article 4.10 of the Subsidies and Countervailing Measures (SCM) Agreement to determine the level of suspension, both of which contain articles which use the word "appropriate". In all subsidy cases, in light of the "inducing compliance" objective and by assessing the broader meaning of "appropriateness", the arbitrators granted an award that is, in lieu of equivalence with the level of nullification, tailored to the total amount of subsidy (total value of violation). In the arbitrators' view, Article 4.10 cannot be confined to redress or neutralise effects only; so the arbitrators established that appropriate countermeasures under Article 4.10 do not have to be restricted to an actual trade effect test. ${ }^{91}$ Therefore, when dealing with prohibited subsidies, arbitrators decided on a different standard, which is an amount of countermeasures that correspond to the total amount of the subsidy. ${ }^{92}$

In the SCM Agreement disputes, arbitrators, by referring to the word "appropriate", have consistently determined that the purpose of countermeasures is to induce compliance and have authorised a countermeasure that is close to punitive sanction. However, even by basing their decisions on the appropriateness standard, arbitrators' determinations on purpose and level of sanction are not free from controversy.

\footnotetext{
${ }^{89}$ The DSU, art 22.4. It states that "the level of the suspension of concessions or other obligations authorised by the DSB shall be equivalent to the level of the nullification or impairment."

${ }^{90}$ Nothing in Article XXIII:2 explicitly limits the suspension to the level of equivalent. The "appropriateness" in Article XXIII:2 can be at the same level with the level of equivalent, but it may also go below or above that level. Mavrodis cites the legal adviser to the Director General of the GATT point of view stating that "Article XXIII, the wording was wider, referring to measures determined to be appropriate... which meant that there was a wider leeway in calculating the retaliatory measures under Article XXIII than under Articles XIX or XXVIII". See Petros C Mavroidis "Remedies in the WTO Legal System: Between a Rock and a Hard Place" (2000) 11 EJIL 763 at 801 ["Between a Rock and a Hard Place"].

${ }^{91}$ US - FSC (Article 22.6-US), above n 13, at [5.20]-[5.24].

${ }^{92}$ Ibid, at [5.57]-[5.62]; Brazil-Aircraft (Article 22.6-Brazil), above n 13, at [3.60].
} 
By referring to the general rules of international law, the International Law Commission Draft Articles on Responsibility of States for Internationally Wrongful Acts (the ILC Draft Articles) ${ }^{93}$ and previous arbitrators' statement in EC - Banana III (US) (Article 22.6 - EC), arbitrators in Brazil - Aircraft (Article 22.6 - Brazil) concluded that "a countermeasure is 'appropriate' inter alia if it effectively induces compliance."94 Thus, the level of appropriate countermeasures is set by arbitrators on the basis of whether the countermeasures have an inducement effect. They provided that if the actual level of nullification or impairment is substantially lower than the offending measure (the subsidy), a countermeasure based on the actual level of nullification will have less or no inducement effect. ${ }^{95}$

The arbitrators' interpretation of appropriateness and the level of nullification seem to clash with their reference to the ILC Draft Articles and some decisions of other international tribunals. While the purpose of countermeasures under international law is definitely inducing compliance, Article 51 of the ILC Draft Articles provides the proportionality provision as a guideline principle so that a countermeasure does not become excessive. Thus, no matter how effective the countermeasure to induce compliance is, if it is not proportional, such countermeasure is not appropriate.

Under Article 51 of the ILC Draft Articles, a countermeasure is proportional when it is commensurate with the injury that is suffered. This is recognised in state practice, doctrine, and confirmed in the Naulilaa and Air Service Agreement arbitration cases. ${ }^{96}$ Therefore, as Palmeter and Alexandrov argue, neither general international law nor the ILC Draft Articles support the conclusion of the Brazil - Aircraft arbitrators when they relied only on the sole stated purpose of

\footnotetext{
${ }^{93}$ The basic rules of international law concerning responsibility of states for internationally wrongful acts are codified and formulated by the United Nations' International Law Commission in the ILC Draft Articles. Although the rules are codified in the "Draft Articles", the United Nations General Assembly adopted resolution 56/83 which "commends [the Draft Articles] to the attention of Governments without prejudice to the question of their future adoption or other appropriate action". See Responsibility of States for Internationally Wrongful Acts GA Res 56/83, A/RES/56/83 (2001).

${ }^{94}$ Brazil-Aircraft (Article 22.6 - Brazil), above n 13, at [3.44].

${ }^{95} \mathrm{Ibid}$, at [3.54].

${ }^{96}$ International Law Commission Draft Articles on Responsibility of States for International Wrongful Acts A/56/10 chp.IV.E.1 (2001) [the ILC Draft Articles], Commentary art 51.
} 
inducing compliance and ignored the proportionality principle by determining a level of countermeasure that is unrelated to the harm suffered. ${ }^{97}$ Additionally, Green and Trebilcock assert that there is no necessary connection between the level of subsidy and the harm caused to other Members; the level of subsidy may be much lower than the harm or higher than the harm. ${ }^{98}$

(b) Larger sanction based on obligations erga omnes in US-FSC

In US - FSC (Article 22.6 - US), the arbitrators ruled that "the prohibition on export subsidies is a per se obligation, not itself conditioned on a trade effects test." 99 They argued that the emphasis is on the "unlawful character of export subsidies", and "the effect of upsetting the balance of rights and obligations between the parties", regardless of the "actual trade effects". 100 Furthermore, the arbitrators referred to the prohibition of export subsidies as an erga omnes obligation owed to each or every Member. Therefore, the arbitrators provided that: ${ }^{101}$

The United States had breached its obligation to the European Communities in respect of all the money that it has expended, because such expenditure in breach...is the very essence of the wrongful act.

In other words, the arbitrators took into account the harm to the entire Members (under the concept of obligation erga omnes) in calculating the level of appropriate countermeasures. Gazzini supports the arbitrators' decision in US - FSC (Article 22.6 - US) by arguing that: ${ }^{102}$

In the cases of obligations concerning both prohibited subsidies and trade in services, contracting parties intend to attach to violations of indivisible obligations some of typical consequences of erga omnes obligations.

\footnotetext{
${ }^{97}$ Palmeter and Alexandrov, above n 63, at 658 .

${ }^{98}$ Andrew Green and Michael Trebilcock "Enforcing WTO Obligations: What We Learn From Export Subsidies?" (2007) 10 JIEL 653 at 674-675.

${ }^{99}$ US - FSC (Article 22.6 - US), above n 13, at [5.23].

${ }^{100}$ Ibid, at [5.23].

${ }^{101}$ Ibid. at [6.10] (emphasis added).

${ }^{102}$ Tarcisio Gazzini "The Legal Nature of WTO Obligations and the Consequences of their Violation" (2006) 17(4) EJIL 723 at 731 ["The Legal Nature of WTO Obligations"].
} 
In Gazzini's view, the different treatment reserved for prohibited and actionable subsidies, and the special nature of trade in services that omits any reference to the concept of nullification and impairment from Article XXII of GATS, demonstrates the erga omnes nature of WTO obligations.

However, the concept of obligation erga omnes considered by the arbitrators in US - FSC is debatable. Howse and Neven argue that "what the panel had in mind, most likely, was the concept of an erga omnes partes obligation". ${ }^{103}$ An erga omnes partes obligation is an obligation owed not only to each Member individually, but collectively to the entire membership. ${ }^{104}$ Nonetheless, Howse and Neven also reject those obligations considered as erga omnes partes, by arguing that the primary interest at stake in dispute settlement is individual Members, notwithstanding the fact that there is community interest in compliance. Dispute settlement rulings are binding between parties to disputes, and not legally binding on the Members as a whole. $^{105}$

(c) Larger penalties as a punitive sanction in Canada-Aircraft II

Canada - Aircraft II (Article 22.6 - Canada) is one example of a subsidy case where arbitrators decided on larger penalties. In this case, the arbitrators decided to adjust the level of countermeasures calculated on the basis of the total amount of the subsidy by an amount (20 per cent) which arbitrators deem reasonably meaningful to cause Canada to reconsider its current position to maintain the subsidy at issue. ${ }^{106}$ The 20 per cent adjustment seems to be a punitive sanction provided by the arbitrators for Canada's reluctance to modify its inconsistent measure.

Many commentators criticise the arbitrators' decision on larger penalties under the SCM Agreement. Palmeter and Mavroidis challenge the view of the arbitrators that considered prohibited subsidies as an aggravating factor rather than a mitigating factor because of the term

\footnotetext{
${ }^{103}$ Robert Howse and Damien J Neven 'United States - Tax Treatment for 'Foreign Sales Corporations' Recourse to Arbitration by the United States under Article 22.6 of the DSU and Article 4.11 of the SCM Agreement (WT/DS108/ARB): A Comment" (2005) 4 WTR 101 at 116.

104 Ibid.

105 Ibid, at 118 .

${ }^{106}$ Canada-Aircraft II (Article 22.6 - Canada), above n 13, at [3.119]-[3.122].
} 
"appropriate" in Article 4.10 and 4.11 of the SCM Agreement that should not be given the same meaning as the term "equivalent" in Article 22 of the DSU. ${ }^{107}$ Palmeter and Mavroidis claim that "the use of the term 'prohibited' for these subsidies is more likely to distinguish them from those that are 'actionable'." 108 Nzelibe emphasises that it is unlikely that an enforcement mechanism that awards sanctions in excess of equivalency would be politically sustainable. In other words, larger penalties might develop into a trade war in which all parties would be worse off. ${ }^{109}$ Cho also states that the arbitral ruling, which imposed a sanction beyond a proportional level, seems excessive since a certain cap in the scale should nevertheless exist in light of equity or fairness. Without such a minimum discipline (proportionality), the sanctions risk being abused or misused, thereby making them illegitimate and unsustainable. ${ }^{110}$

\section{WTO Law in Relation to Other Legal Systems}

In order to provide a comprehensive assessment with respect to the purpose(s) of WTO retaliation, some discussions in this thesis refer to non-WTO law. There are two areas that this thesis looks at: public international law and contract. Commentators and observers have various opinions concerning the relationship between WTO law and these areas of study. The subsequent part explains their views.

\section{WTO law in relation to public international law}

The WTO is an inter-governmental organisation whose Members are actively engaged in international trade relations based on the agreements amongst themselves. In their trade interactions/relations, Members might perform an action or omission or both, that negatively affects other Members' rights. Under public international law, such conduct can be considered as a wrongful act and every internationally wrongful act entails international responsibility. The provisions for international wrongful acts are laid down under the ILC Draft Articles. Public international law also provides provisions governing international treaties: the Vienna

\footnotetext{
${ }^{107}$ Palmeter and Mavroidis, above n 18, at 291.

108 Ibid, at 292.

${ }^{109}$ Nzelibe, above n 27, at 344.

${ }^{110}$ Cho, above n 25, at 779.
} 
Convention on Law and Treaties (VCLT). ${ }^{111}$ As these two general rules appear to interweave with WTO law, the question as to whether WTO law can fall back on those general rules of public international law; or whether they do not apply because WTO law has contracted out of them, comes to the surface.

$$
\text { Is WTO law a self-contained regime? }
$$

As a global trading system, the WTO sets up the rules of trade applied to nations as its Members. The "public international" character of WTO raises the issues of whether it is a part of international law or a self-contained regime.

McRae argues from the traditional view that international trade law is considered outside the sphere of international law. ${ }^{112}$ Several arguments are presented by McRae, such as the fact that trade law is "technical" and its field is "special", trade law is not seen as emerging from state practice but is seen more as the law of business transactions between individuals, and international trade law has nothing to do with sovereignty. ${ }^{113}$ Pauwelyn criticises McRae's view by stating that: ${ }^{114}$

Whereas McRae's first and second reasons...are convincing, this third reason is both misleading and erroneous. It falls into the very trap that McRae himself warned about, namely the trap for trade lawyers to portray 'their' discipline as something 'special'.

Pauwelyn argues that McRae utilises a wrong benchmark to compare trade law with international law. He refers to, on the one hand, the traditional international law concept of "coexistence", and on the other hand, the modern international law concept of "co-operation"

\footnotetext{
111 Vienna Convention on the Law of Treaties 1969, done at Vienna on 23 May 1969 entered into force on 27 January 1980, United Nations Treaties Series Vol 1155, p 331.

112 Donald McRae "The Contribution of International Trade Law to the Development of International Law" (1996) 260 Recueil des Cours 109 ["The Contribution of International Trade Law"]; Peter Van den Bossche The Law and Policy of the World Trade Organization: Text, Cases and Materials (Cambridge University Press, 2005) at 61; Joost Pauwelyn Conflict of Norms in Public International Law: How WTO Law Relates to Other Rules of International Law (Cambridge University Press, 2003) at 29-31 [Conflict of Norms in Public International Law].

${ }^{113}$ McRae "The Contribution of International Trade Law", above n 112, at 115-117.

${ }^{114}$ Pauwelyn Conflict of Norms in Public International Law, above n 112, at 31.
} 
including GATT/WTO law. Thus, Pauwelyn concludes that McRae is not comparing international law to trade law, but old international law to new international law. ${ }^{115}$

Furthermore, what is a self-contained regime? The ILC draft report on fragmentation of international law finalised by Koskenniemi notes that self-contained regimes may be established from a set of rules and principles that apply as lex specialis. ${ }^{116}$ Simma and Pulkowski state that the concept of a strong lex specialis is a self-contained regime. ${ }^{117}$

Is WTO law a self-contained regime? Pauwelyn suggests that "it is not a 'self-contained' regime in the sense of a regime existing outside of international law."118 He argues that "states can 'contract out' of one or more (other than jus cogens) rules of international law, but they cannot contract out of the system of international law." 119 The Appellate Body in US - Gasoline, also firmly acknowledged that WTO law is not a self-contained regime, stating that the Agreement "is not to be read in clinical isolation from public international law." ${ }^{120}$ For example, the rules of interpretation under Article 3.2 of the DSU refer to the customary rules of treaty interpretation of public international law.

I agree with most commentators that WTO law is not a self-contained regime. Panels and the Appellate Body have referred to general international law as a consideration or cited the decisions of other international tribunals to support their decisions in a number of disputes. Moreover, Article 3.2 of the DSU explicitly demonstrates that WTO law has contracted in the customary rules of treaty interpretation of public international law. This shows that WTO does not rule out the general rules of international law entirely.

\footnotetext{
115 Ibid, at 32 .

${ }^{116}$ Martti Koskenniemi Fragmentation of International Law: Difficulties Arising from the Diversification and Expansion of International Law A/CN.4/L.682/Add.1 (2006) at 6.

${ }^{117}$ Brunno Simma and Dirk Pulkowski "Of Planets and the Universe: Self-Contained Regimes in International Law" (2006) 17(3) EJIL 483 at 490.

${ }_{118}$ Pauwelyn Conflict of Norms in Public International Law, above n 112, at 37.

119 Ibid.

${ }^{120}$ United States - Standards for Reformulated and Conventional Gasoline WTO DOC WT/DS2/AB/R (1996) at [17] (Report of the Appellate Body) [US - Gasoline (AB)].
} 
(b) WTO remedies and public international law remedies: inclusive or exclusive from the system?

Public international law offers several remedies for the injured states as a result of international wrongful acts. Some forms of the remedies are cessation of wrongful acts under Article 30 of the ILC Draft Articles, countermeasures under Article 49 of the ILC Draft Articles, and reparation under Article 31 of the ILC Draft Articles. Similar to public international law, the DSU provides several remedies under its scheme. However, some characters and forms of the DSU remedies are different from those under public international law. For example, the DSU does not stipulate financial compensation in its text. Thus, the question is whether remedies under public international law overrule WTO remedies, or equally important, whether WTO remedies can fall back on remedies under public international law.

Article 55 of the ILC Draft Articles, reflecting the maxim lex specialis derogat legi generali, provides that the articles do not apply where and to the extent that the conditions for the existence of an internationally wrongful act or its legal consequences are determined by special rules of international law. Therefore, we must determine whether remedies under the DSU incorporating special rules (lex specialis) exclude the application of state responsibility under the general rules of international law.

Simma and Pulkowski also argue that remedies under the DSU embrace a full, exhaustive and definitive subsystem (secondary rules) which would exclude application of state responsibility under the general rules of international law as the primary rules. ${ }^{121}$ Van den Bossche, at the same time, asserts that by providing a detailed set of rules regarding remedies, the DSU has contracted out of the general rules of international law on State Responsibility. ${ }^{122}$

I agree with the view that the remedies under the DSU are lex specialis. The WTO has contracted out of general rules of international law with respect to the remedies. This issue is examined further in chapter three below.

\footnotetext{
${ }^{121}$ Simma and Pulkowski, above n 117, at 493.

${ }^{122}$ Van den Bossche, above n 112, at 224.
} 
In conclusion, this thesis takes the standpoint that WTO law is not a self-contained regime. In a number of cases, panels and/or the Appellate Body have applied or made reference to customary rules and general principles of international law. The question is to what extent does public international law play a role in WTO law? The panel in Korea-Measures Affecting Government Procurement interpreted the relationship between the WTO and public international law in a broader way than merely a relationship of interpretation rules. The panel stated that: ${ }^{123}$

Customary international law applies generally to the economic relations between the WTO Members. Such international law applies to the extent that the WTO treaty agreements do not 'contract out' from it.

In contrast, the United States challenged the insertion of the rules of public international law outside the customary rules of interpretation in WTO dispute settlement. ${ }^{124}$ Nonetheless, as I state further in chapter three below, it is not the intention of this thesis to resolve this issue. This thesis focuses mainly on the application of customary rules of treaty interpretation ("contract in") and remedies under public international law ("contract out") issues.

\section{WTO law in relation to contract}

Some commentators, particularly those who argue that compliance is not mandatory, provide contractual incompleteness of WTO agreements as their main argument. Green and Trelbicock, for instance, argue that WTO agreements are incomplete contracts and that compliance is not mandatory in all cases as the Members have built-in flexibility mechanisms to allow adjustments to new situations. They support the efficient breach theory that the remedies should be aimed at permitting breaches or adjustments when efficient, either on political or welfare basis. ${ }^{125}$ Similarly, Sykes and Schwartz utilise the public choice approach and refer to WTO agreements as contracts among the political actors. They assert that WTO Agreements are

\footnotetext{
${ }^{123}$ Korea-Measures Affecting Government Procurement WTO DOC WT/DS163/R (2000) at [7.96] (Report of the WTO Panel) [Korea - Government Procurement (Panel)].

${ }^{124}$ Dispute Settlement Body Minutes of Meeting - Held in the Centre William Rappard on 7 May 2003 WTO DOC WT/DSB/M/149 (8 July 2003) at para 20.

${ }^{125}$ Green and Trelbicock, above n 98, at 660.
} 
incomplete contracts that encourage efficient performance of commitments while facilitating efficient breach of commitments. ${ }^{126}$

Nonetheless, other commentators are against these views. Fukunaga, for example, disagrees with the efficient breach theory by arguing that nothing in the DSU provides that the DSB can choose either to make recommendations or to award damages. She argued that recommendations are the primary remedy option, compensation and suspension of concessions are alternative remedies and are only available in the event that the recommendations are not implemented within a reasonable period of time. ${ }^{127}$ Additionally, Cho points out that Sykes' analogy to a private contract creates a misunderstanding as to the real identity of the WTO legal system. He argues that the WTO is no more "a mere contract among the contracting parties, but an independent international organization established by its Members in order to envisage an integrated legal system for international trade." 128 And therefore in his view, the concept of efficient breach is unacceptable under this legal system. ${ }^{129}$ Steger also argues that the "WTO Agreement is not a commercial contract that countries can cancel whenever it suits them, nor is it 'soft law' that is not binding on Members.","130

In my point of view, the WTO is an international "contract organisation". It is a multilateral contract amongst nations that establishes the WTO as an international organisation. ${ }^{131}$ The Appellate Body in Japan - Alcoholic Beverages explicitly affirmed the "contract" character of the WTO by stating that "the WTO Agreement is a treaty - the international equivalent of a contract". ${ }^{132}$

\footnotetext{
${ }^{126}$ Schwartz and Sykes, above n 64, at S180-S183.

127 Yuka Fukunaga "Securing Compliance through the WTO Dispute Settlement System: Implementation of DSB Recommendations" (2006) 9 JIEL 383 at 397.

${ }^{128}$ Cho, above n 25, at 783 .

${ }^{129}$ Ibid.

${ }^{130}$ Debra P Steger "The Culture of the WTO: Why It Needs to Change" (2007) 10(3) JIEL 483 at 490-491.

131 Simon A B Schropp "Trade Policy Flexibility and Enforcement in the WTO - Reform Agenda towards an Efficient "Breach" Contract" (PhD Thesis, University of St. Gallen, 2008) at 148 ["Trade Policy Flexibility and Enforcement"].

${ }^{132}$ Japan - Taxes on Alcoholic Beverages WTO DOC WT/DS8/AB/R WT/DS10/AB/R WT/DS11/AB/R (1996) at [15] (Report of the Appellate Body) [Japan-Alcohol Beverages (AB)].
} 
With this in mind, it is relevant to analyse the problem (the purpose(s) of retaliation) from a contract-theoretic point of view. Schropp states that it is in the contract design stage that the parties determine what their substantive goals are and how these goals are achieved in the most effective way. ${ }^{133}$ In chapter 4 below, I establish the assessments that look to the design of WTO treaty to articulate the purposes of retaliation.

\section{Options to improve remedies}

Some scholars and commentators provide options to enhance and improve the effectiveness of temporary remedies. For instance, Bronckers and van den Broek, and Fukunaga suggest financial or monetary compensation as an option. ${ }^{134}$ Fukunaga argues that one of the advantages of monetary compensation is that it allows for the provision of non-MFN compensation, since monetary compensation, unrelated to particular import or export transactions, neither distorts trade nor increases the transaction cost. ${ }^{135}$ Other commentators, such as Rafiqul Islam and Udombana, suggest multilateral collaborative efforts. Through a collective process, weaker injured Members can have access to remedial justice; and the application itself is the last resort to bring international pressure on the recalcitrant Member to comply. ${ }^{136}$ Choi proposes rotating retaliation combined with an increasing level of retaliation over time. This approach should be subject to the proportionality standard and should not have a punitive nature. Moreover, Choi also proposes such multilateral remedies as: (a) restricting a non-complying Member's voting rights; (b) obliging a non-complying party to pay legal costs incurred by the complaining party; and (c) requiring a non-complying party to make a financial contribution to certain neutral institutions such as the Advisory Centre on WTO Law (ACWL). ${ }^{137}$

Charnovitz proposes a "transparency and sunshine" method. All of the DSU bodies should hold most of their sessions in public. Whenever a government fails to comply, the DSB

\footnotetext{
${ }^{133}$ Schropp "Trade Policy Flexibility and Enforcement", above n 131, at 42.

${ }^{134}$ Bronckers and van den Broek, above n 24; Fukunaga, above n 127, at 415.

${ }^{135}$ Fukunaga, above n 127, at 415.

${ }^{136}$ M Rafiqul Islam "Recent EU Trade sanctions on the US to Induce Compliance with the WTO Ruling in the Foreign Sales Corporation Case: Its Policy Contradiction Revisited" (2004) 38(3) JWT 471 at 481-487; see also Udombana, above n 39, at 1197-1199, the author suggests collective countermeasures through African Union.

137 Won-Mog Choi "To Comply or Not to Comply? - Non-implementation Problems in the WTO Dispute Settlement System" (2007) 41(5) JWT 1043 at 1067-1069.
} 
should convene a public hearing where a government would be asked to explain its delays, and other governments and concerned private economic and social actors could respond. ${ }^{138}$ Van den Broek also provides some additional ideas, such as changes in the methods for calculations of the level of suspension or compensation; regular review of compliance with the Secretariat's dispute settlement reports; specific suggestions for compliance with dispute settlement reports; and damages in the case of mala fide non-compliance at the end of the compliance period. ${ }^{139}$ Other scholars suggest enhancing cross-retaliation as a mechanism to induce compliance for a developing country complainant Member. ${ }^{140}$

A number of WTO Members have also proposed reforms of the current retaliation system. Their proposals, amongst others, include: collective retaliation, ${ }^{141}$ increasing the capacity of trade compensation, ${ }^{142}$ earlier determination of level of nullification or impairment, ${ }^{143}$ introduction of the right to request or to take preventive measures in exceptional situations, ${ }^{144}$ enhancing cross-retaliation, ${ }^{145}$ and tradable retaliation ${ }^{146}$.

Those proposals are worth being considered in order to enhance the performance of WTO remedies; even though they are also not free from criticism and controversy. Chapter two below further explains these reform proposals.

\footnotetext{
${ }^{138}$ Charnovitz "Last Resort against Noncompliance", above n 8, at 431-432.

${ }^{139}$ Naboth van den Broek "Power Paradoxes in Enforcement and Implementation of World Trade Organization Dispute Settlement Reports: Interdisciplinary Approaches and New Proposals" (2003) 37(1) JWT 127 at 157-160.

140 Lucas Eduardo F A Spadano "Cross-agreement Retaliation in the WTO Dispute Settlement System: An Important Enforcement Mechanism for Developing Countries?” (2008) 7(3) WTR 511 at 533. See also Arvind Subramanian and Jayashree Watal "Can TRIPS Serve as an Enforcement Device for Developing Countries in the WTO?" (2000) 3 JIEL 403.

${ }^{141}$ Mostly supported by least-developed countries and the Africa group. See also Udombana, above $\mathrm{n} 39$, at 1198 .

${ }^{142}$ Ecuador, for example, realised the short period of time (20 days) in negotiating compensation, therefore it proposed the possibility of negotiating compensation at all stage of sequence.

${ }_{143}$ Ecuador proposed to determine the level of nullification when determining the reasonable period of time under Article 21.3(a) or when it is mutually agreed by parties under Article 21.3. Mexico even went further by proposing retroactive determination and application of nullification or impairment (date imposing the measure or the date of the request for consultation or the date of establishment of panel).

${ }^{144}$ Mexico proposed that such right be activated when, for example, the challenged measure is causing damage that would be difficult to repair.

${ }^{145}$ The proposal is to ensure that cross-retaliation is the exception rather than the rule, so the developing country complaining Member could cross-retaliate whenever it sees fit to do so.

${ }^{146}$ Mexico proposed that Members should be allowed to "negotiate" the right to suspend or transfer the right to suspend toward another Member.
} 


\section{Structure of the Thesis}

This thesis consists of six chapters. Chapter one introduces the main problem: the question of the effectiveness and the purpose(s) of retaliation. It also elaborates on the dilemmas experienced by WTO remedies amidst the high compliance enjoyed by WTO dispute settlement, and subsequently, presents various views from scholars, commentators and WTO Members concerning the issues of retaliation and the areas of study in this thesis. Finally, it states the methodology, scopes of the thesis and contribution of thesis to scholarship.

Chapter two has two main parts of discussion. The first part elaborates on the basic features, nature and substantive rules of GATT/WTO retaliation. The purpose of this part is to provide a basic understanding of WTO retaliation under the DSU and the countermeasures under the SCM Agreement. The second part examines two important issues: the shortcomings of retaliation, and the reform proposals of retaliation.

The key discussion of chapter three is about the question of effectiveness and the purpose(s) of retaliation. This chapter draws attention to the importance of determining the meaning of effectiveness, before responding to the question about the effectiveness of WTO retaliation. Following that, this chapter highlights the significance of identifying the purpose in measuring the degree of the effectiveness. Thus, a search of the purpose(s) of retaliation is conducted in this chapter, namely through: interpreting Article 22 of the DSU, examining the reference made by the arbitrators to the remedies of public international law, assessing academic writings or debates and the statements of arbitrators related to the purpose(s) of retaliation. This chapter provides that retaliation can have multiple purposes: inducing compliance, rebalancing, and reaching a mutually satisfactory solution.

Chapter four examines the multiple purposes of retaliation from the structure of the WTO treaty. This chapter establishes three levels of assessment: the first level provides an analysis of the nature of WTO dispute settlement and retaliation entitlements; the second level elucidates on the transferability of the WTO entitlements and how these entitlements are protected (intracontractual commitments); and the third level examines the back-up enforcement level with 
relation to the WTO preference for compliance (extra-contractual commitments). These three levels of assessment provide that the structure of WTO treaty accommodates the multiple purposes of retaliation.

Chapter five proposes another purpose of retaliation: mutually agreeable solutions. This purpose was achieved in the $E C$ - Hormones dispute. Moreover, by referring to the definition of effectiveness and the analysis of the purposes of retaliation, the chapter states that even though there is room for improvement, WTO retaliation performs reasonably well in light of its multiple purposes.

Chapter six contains the conclusion of the thesis. This part summarises the main problems and arguments of the thesis, as well as states the outcomes reached in the thesis.

\section{Methodology and the Scope of the Thesis}

There are several types of legal research: explanatory (explaining the law), empirical (identification of the valid law), hermeneutic (interpretation, argumentation), exploring (searching for new or fruitful path), logical (structuring concepts, rules), instrumental (conceptbuilding), and evaluative (testing the applicability of the rule in practice). ${ }^{147}$ The research in this thesis can be categorised as a "hermeneutical" type. It involves interpreting the legal text (the DSU), providing arguments to sustain the interpretation, and analysing the text, theories, and cases. $^{148}$

Overall, the research in this thesis is conducted as follows: firstly, the research begins with finding the legal issues or problems. Secondly, following the establishment of the legal issues, various sources (primary and secondary) are collected. Primary sources consist of, inter alia, the WTO panels and/or the Appellate Body reports, the arbitrators' decisions, the WTO legal text, WTO Secretariat documents, the DSU negotiating history, the DSB minutes of

\footnotetext{
${ }^{147}$ Mark Van Hoecke (ed) Methodologies of Legal Research: Which Kind of Method for What Kind of Discipline? (2011, Hart Publishing).

${ }^{148}$ Ibid, at 4.
} 
meeting. Secondary sources include text books, monographs, edited collections, conference papers, unpublished seminars and papers, unpublished theses and research papers, and legal encyclopaedias. Thirdly, after the collection of the data, the assessments (interpretation and analysis of the sources) begin. The research in this thesis employs a normative (literature/text analysis) method. Interviews, field studies and the like are not appropriate.

This thesis looks at the phase of non-implementation in WTO dispute settlement. Retaliation under the DSU is the main area of the study; nevertheless this thesis has to put in place several limitations regarding the areas of examination. In this regard, this thesis deals with violation complaints; and there are no, or very limited, discussion of non-violation complaints. Moreover, the thesis elaborates on the issues under legal perspective. Other dimensions, such as economic, politic, social, and ethical dimensions, are utilised as supporting information and are not discussed intensively. The research focuses on the issue of DSU remedies, and not on trade remedies such as anti-dumping and countervailing duties. Nonetheless, there are several discussions in this thesis regarding countermeasures under the SCM Agreement.

\section{Contribution of Thesis to Scholarship}

Many scholars and commentators observe retaliation from the "harm-resulted" perspective. Most studies also utilise the parameter of inducing compliance in order to measure the effectiveness of retaliation. The imposition of retaliation undeniably results in harm because retaliation, by nature, is trade restrictive.

This thesis provides that compliance and effectiveness, although related, are distinct. The study in this thesis posits that effectiveness goes beyond compliance to determine whether a rule or standard achieves its purpose or objective. Consequently, to respond to the question of whether retaliation is effective or not, it is significant to identify the purposes of retaliation. This is the area in which the current study has lack of awareness. 
Scholars, commentators, as well the arbitrators predominantly argue the single purpose of retaliation: either inducing compliance or rebalancing. ${ }^{149}$ My study, nevertheless, advocates the multiple purposes of retaliation: inducing compliance, rebalancing and reaching a mutually satisfactory solution. The standpoint of multiple purposes is established on the basis of the research of Article 22 (through interpretation in accordance with the customary rules of international law) and the structure of WTO treaty. The study in this thesis helps to provide a complete picture about the purposes and effectiveness of retaliation.

In conclusion, there are two main contributions of this thesis to the scholarship: firstly, this thesis provides a clear and certain scheme in assessing the effectiveness of retaliation; secondly, it provides a more comprehensive study of the purposes of retaliation than the current academic writings have provided.

${ }^{149}$ For example the arguments between Jackson and Bello. 


\title{
CHAPTER TWO \\ RETALIATION: SHORTCOMINGS AND REFORM PROPOSALS
}

\begin{abstract}
"The principle of no right without a remedy has, however, a peculiar twist in the GATT. In an important sense Article XXIII gives a remedy without a right.",

"[R]etaliation has the disadvantage of requiring the complaining Member to 'shoot itself in the foot' by restricting imports and thus hurting its own industrial users, importers and consumers. "’
\end{abstract}

\section{Overview}

The dispute settlement system has been evolved and strengthened by the advent of the WTO. The rules contained in the Dispute Settlement Understanding (DSU) eliminate several shortcomings in the GATT dispute settlement regime and provide clearer time-frames and clearer dispute procedures. Another appealing improvement is the provision of remedies in the case of continued non-compliance.

Retaliation is considered to be a self-help instrument utilised by an injured state to force the violator state to withdraw its inconsistent measures in the event of continued noncompliance. Nevertheless, numerous commentators demonstrate discontent with the WTO retaliation measures. ${ }^{3}$ Its ineffectiveness in inducing compliance is recognised as the major problem with retaliation.

This chapter has three main topics: the basic features and rules of retaliation under the GATT, the DSU and the SCM Agreement; ${ }^{4}$ the shortcomings and problems of retaliation from

\footnotetext{
${ }^{1}$ Kenneth W Dam The GATT: Law and International Economic Organization (the University of Chicago Press, 1970) at 358.

${ }^{2}$ Bronckers and van den Broek, above ch 1, n 24, at 101 (emphasis added).

${ }^{3}$ Ibid; Mateo Diego-Fernández "Compensation and Retaliation: A Developing Country's Perspective" in George A Bermann and Petros C Mavroidis (eds) WTO Law and Developing Countries (Cambridge University Press, 2007); Cho, above ch 1, n 25; Udombana, above ch 1, n 39; Amin Alavi "African Countries and the WTO's Dispute Settlement Mechanism" (2007) 25(1) Development Policy Review 25 ["African Countries and the WTO's Dispute Settlement Mechanism"].

${ }^{4}$ Although the main analysis of this thesis is retaliation under the DSU, it is also important at some points to discuss the countermeasures under the SCM Agreement. The underlying reasons are: firstly, several Article 22.6 arbitral proceedings are to determine the level of countermeasures. Secondly, retaliation and countermeasures have similar 
academic perspective and practice; and reform proposals offered by the WTO Members and other commentators. Moreover, before entering into the central discussions in this thesis, one needs a basic understanding on what retaliation is. Accordingly, this chapter begins with the nature and features of retaliation.

\section{Nature, Features and Substantive Rules of GATT/WTO Retaliation}

The issue of non-compliance emerges when a violator State continues to maintain its inconsistent measures notwithstanding an adopted panel/Appellate Body report that recommends the violator Member bring its illegal measure into compliance. As explained in the introductory chapter, the WTO provides two kinds of remedies for the non-compliance problems. These are mutually acceptable compensation and suspension of concessions or other obligations.

Article 22 of the DSU provides that if the violator state fails to bring the inconsistent measures into compliance within a reasonable period of time, such Member shall enter into negotiations with the injured state to "develop mutually acceptable compensation". If no satisfactory compensation has been agreed, any party to the dispute may request authorisation for the suspension of concessions or other obligations (retaliation). In short, Article 22 provides an option to a violator state who fails to bring its inconsistent measures into compliance that it can either enter into negotiations for compensation or suffer retaliation.

Article 3.7 of the DSU provides a hierarchy of remedies available under WTO dispute settlement. It gives preference first of all to a solution which is mutually acceptable. In the absence of such an agreed solution, withdrawal of the inconsistent measure is the main objective of the WTO dispute settlement system. If the withdrawal is impracticable, the injured party can resort to the provision of compensation. Retaliation, ultimately, is the last resort which the DSU provides to the injured Member.

form and characters, and several issues are applicable to both retaliation and countermeasure, unless the SCM Agreement states otherwise. Thirdly, we can have a proper study of retaliation under the DSU by doing an observation with respect to the countermeasures under the SCM Agreement. 
The main focus of this assessment is retaliation; however it is important to explain first trade/tariff compensation. Despite the fact that only in a few cases parties to a dispute have referred to compensation, trade/tariff compensation is one form of GATT/WTO remedy that parties to a dispute can agree on or utilise to settle the dispute. The subsequent part discusses several features of WTO compensation briefly.

\section{A Trade/Tariff Compensation}

The term "compensation", during the GATT era, appeared in the 1979 Understanding, which provided that compensation should be resorted to only if the immediate withdrawal of the measure was impracticable, and it was seen as a temporary measure pending the withdrawal of the inconsistent measures. ${ }^{5}$ In US - Sugar Waiver, the GATT panel, by referring to Paragraph 4 of the 1979 Understanding, noted that a contracting party might choose to grant compensation to forestall the request for an authorisation of retaliatory measures, but the Understanding did not oblige it to do so. ${ }^{6}$ In other words, the panel decided that compensation was optional and that it was up to the respondent to decide whether or not to compensate. ${ }^{7}$

Under the WTO, Article 21.1 of the DSU provides that compensation is temporary, voluntary and shall be consistent with the covered agreements. Many commentators argue that the last characteristic (consistent with the covered agreements including the MFN principle) makes compensation less preferred or less attractive. ${ }^{8}$ Since compensation here is more within the meaning of trade benefit/openness under preferential basis, by providing this benefit the respondent state is also required, under the MFN principle, to extend this benefit or advantage to other WTO Members. Consequently, parties have to select a sector of the respondent Member's

\footnotetext{
${ }_{6}^{5}$ Paragraph 4 of the Annex to the 1979 Understanding.

${ }^{6}$ United States - Restriction on the Importation of Sugar and Sugar Containing Products Applied under 1955 Waiver and under the Headnote to the Schedule of Tariff Concessions GATT BISD 37th Supp 228 GATT DOC L/6631 - 37S/228 (1990) at [5.22] (Report of the Panel adopted 7 November 1990).

${ }^{7}$ Sherzod Shadikhodjaev Retaliation in the WTO Dispute Settlement (Kluwer Law International, 2009) at 22.

8 Adebukola A Eleso "WTO Dispute Settlement Remedies: Monetary Compensation as an Alternative for Developing Countries" (2006) Bepress Legal Series Paper 1378 at 12-14; Bryan Mercurio "Why Compensation Cannot Replace Trade Retaliation in the WTO Dispute Settlement" (2009) 8(2) WTR 315 at 324-325 ["Why Compensation Cannot Replace Trade Retaliation"]; Pei-Kan Yang "Some Thoughts on a Feasible Operation of Monetary Compensation as an Alternative to Current Remedies in the WTO Dispute Settlement" (2008) 3 Asian J WTO\&Int'l Health L\&Pol'y 423 at 430.
} 
trade that is less attractive for other Members, but nevertheless, significant for the complaining Member's trade. ${ }^{9}$

In practice, there are few disputes where Members have utilised trade compensation as a remedy. ${ }^{10}$ For example in Japan - Alcoholic Beverages II, Japan provided compensation in the form of a tariff reduction on certain products to the United States, the European Communities and Canada as the complainants to the case. ${ }^{11}$ Moreover, US - Section 110(5) Copyright Act, is the only dispute in which parties agreed to financial compensation instead of tariff compensation.

Some scholars suggest financial/monetary compensation as an alternative to trade compensation or retaliation. ${ }^{12}$ Financial/monetary compensation as a remedy is not a novel idea under the GATT/WTO system. In 1965, Brazil and Uruguay proposed that financial compensation be included in the GATT, but the contracting parties did not accept the idea. ${ }^{13}$ In the current Doha Development Agenda negotiations on the DSU, the least-developed countries and Ecuador, for instance, have proposed monetary compensation as one of the WTO dispute settlement remedies. ${ }^{14}$ Strengthening trade/tariff compensation and providing financial/monetary compensation under reform proposals to WTO remedies are explained in more detail in the subsequent part of this chapter.

\footnotetext{
${ }^{9}$ Shadikhodjaev, above n 7 , at 22.

${ }^{10}$ For instance, trade compensation was reached in Japan - Alcoholic Beverages, Turkey - Textile, US - Line Pipe disputes. See above ch $1, \mathrm{n} 16$.

${ }^{11}$ Japan - Taxes on Alcoholic Beverages - Mutually Acceptable Solution on Modalities for Implementation, above ch 1, n 16.

${ }^{12}$ Bronckers and Van den Broek, above ch 1, n 24.

${ }^{13}$ Committee on Trade and Development Ad Hoc Group on Legal Amendments to the General Agreement Proposal Submitted by the Brazilian and Uruguayan Delegations - Draft Decision on Article XXIII GATT DOC COM.TD/F/W/4 (11 October 1965) at para 7. See also Shadikhodjaev, above n 7, at 22-23.

${ }^{14}$ Dispute Settlement Body Special Session Negotiations on the Dispute Settlement Understanding - Proposal by the LDC Group WTO DOC TN/DS/W/17 (9 October 2002); Dispute Settlement Body Special Session Negotiations on Improvements and Clarifications of the Dispute Settlement Understanding - Proposal by Ecuador WTO DOC TN/DS/W/33 (23 January 2003).
} 


\section{B Law to Retaliate under GATT and WTO}

Retaliation is the eventual remedy provided under this multilateral trading system when parties to a dispute have failed to reach an agreement on mutually acceptable compensation. Extensive academic writings, studies and reports have discussed retaliation; this part primarily examines the law governing retaliation under the GATT and, later, under the WTO.

\section{The term "retaliation"}

Neither the text of the International Trade Organisation (ITO) Charter nor the GATT nor the DSU actually utilises the term "retaliation". Nevertheless, the word "retaliation" was often used by the negotiators in the ITO and GATT meetings. ${ }^{15}$ Moreover, the panel in US - Certain EC Products described the character of suspension of concessions as retaliatory in nature. ${ }^{16}$ Numerous commentators and observers now utilise the term "retaliation" in referring to the remedy under suspension of concessions. In his work on the terms of sanctions under WTO law, Charnovitz points out that it is not clear when retaliation becomes the general term for the action under Article XXIII. ${ }^{17}$ However, Charnovitz explains that the repeated use of the term "retaliation" in Kenneth Dam's book (The GATT: Law and International Economic Organization) may have popularised the term. ${ }^{18}$

Moreover, even though retaliation is often referred to as a "trade sanction", the term of sanction here is not meant punitively. ${ }^{19}$ In this thesis, several terms are going to be used interchangeably in referring to retaliation under WTO and public international law, such as suspension of concessions or other obligations, countermeasures and sanctions. Retaliation and

\footnotetext{
${ }^{15}$ John H Jackson World Trade and the Law of GATT (Bobbs-Merrill, 1969) at 170-171; Olivier Long Law and Its Limitation in the GATT Multilateral Trade System (Martinus Nijhoff Publishers, 1987) at 66; WTO Secretariat Guide to GATT Law and Practice (1965) Volume 2 Article XXII-XXXVIII (Geneva, WTO, 1995) at 693.

${ }^{16}$ United States - Import Measures on Certain Products from the European Communities WTO DOC WT/DS165/R (2000) at [6.23] (Report of the WTO Panel) [US - Certain EC Products (Panel)].

${ }^{17}$ Steve Charnovitz "Rethinking WTO Trade Sanctions" (2001) 95(4) Am J Int'1 L 792 at 801 ["Rethinking WTO Trade Sanctions"] at 801 .

${ }^{18}$ Ibid.

${ }^{19}$ For example, Olivier Long states that neither punitive action nor direct coercion is provided for in the General Agreement. See Olivier Long, above n 15, at 66.
} 
suspension of concessions are utilised mostly in the context of the DSU, while countermeasures are used in the context of the SCM Agreement and public international law.

There were two cases during GATT dispute settlement where injured parties requested authorisation for retaliation: US - Suspension of Obligations ${ }^{20}$ and $U S-$ Superfund. ${ }^{21}$ In US Suspension of Obligations, the Netherlands proposed an authorisation for a countermeasure in the form of an annual reduction of United States exports of wheat flour. ${ }^{22}$ The working party subsequently provided the amount that they deemed appropriate and authorised the suspension of obligations to the Netherlands. ${ }^{23}$ However, the Netherlands did not impose such authorised suspension of obligations. ${ }^{24}$ In US - Superfund, both Canada and the European Communities requested authorisation for retaliation; however, the request was blocked by the United States. ${ }^{25}$

In Dam's view, there are two considerations as to why the GATT parties avoided recourse to retaliation. First is the preference of Contracting Parties to act as conciliators rather than arbitrators and thus they had the tendency to postpone as long as possible the imposition of retaliation. ${ }^{26}$ Second is that retaliation may also result in harm to the retaliating party. ${ }^{27}$ Due to the fact that authorised suspension of obligations was never utilised, the effectiveness of retaliation as a remedy was never tested during the GATT era. ${ }^{28}$

\footnotetext{
${ }^{20}$ Netherlands Action under Article XXIII:2 to Suspend Obligations to the United States GATT BISD 1st Supp 62 GATT DOC L/61 (1952) (Report of the GATT Working Party adopted 8 November 1952) [US - Suspension of Obligations].

${ }^{21}$ United States - Taxes on Petroleum and Certain Imported Substances GATT BISD 34th Supp 136 GATT DOC L/6175 - 34S/136 (1987) (Report of the Panel adopted 17 June 1987) [US - Superfund (Panel)].

${ }^{22}$ US - Suspension of Obligations, above n 20, at [1].

${ }^{23}$ Ibid, at [7].

${ }^{24}$ Charnovitz "Rethinking WTO Trade Sanctions" above n 17, at 802.

${ }^{25}$ Pauwelyn "Enforcement and Countermeasures", above ch 1, n 84, at 335.

${ }^{26}$ Dam writes that although the Contracting Parties in several cases have found nullification or impairment, they have avoided authorising retaliation, for instances in the Australian fertilizer case, the French compensatory tax case, and the French import restriction case. See Dam, above n 1, at 364.

${ }^{27}$ Ibid, at 368 .

${ }^{28}$ Charnovitz "Rethinking WTO Trade Sanctions", above n 17, at 802.
} 
There are two requirements under GATT Article XXIII:2 for the authorisation of the suspension of concessions or other obligations (retaliation) by the contracting parties. They are: (1) there are "serious enough circumstances"; and (2) the proposed suspension is "appropriate".

What constitutes "serious enough circumstances" can be derived from GATT practices. The first component of "serious enough" is the existence of nullification or impairment. ${ }^{29}$ The second component is that all endeavours to solve the problem through all other remedies have not proved successful. ${ }^{30}$ Finally, the third component is that the retaliation action taken is to prevent serious economic consequences of nullification or impairment, or to restore the original situation. $^{31}$

Determination of the "appropriate" standard has proven to be quite problematic. There were several practices and statements during the GATT era in an attempt to define “appropriateness". For instance, a 1988 statement by the Legal Adviser to the GATT Director General stated that in the case of Article XXIII, the wording ("appropriate") was wider, which meant that there was wider leeway in calculating the retaliatory measures under Article XXIII than under Article XIX or XXVIII. ${ }^{32}$ Consequently, the GATT Deputy Director in considering the EEC's request for the authorisation to retaliate against the United States stated that: ${ }^{33}$

Article XXIII:2, unlike Article XXVIII, did not speak about equivalent concessions. Therefore, it was not really a question of authorizing the withdrawal of equivalent concessions as such. That was why the Secretariat had pointed out that Article XXIII did not require that the amount of retaliation should be equivalent.

\footnotetext{
${ }^{29}$ Uruguayan Recourse to Article XXIII GATT BISD 11th Supp 95 GATT DOC L/1923 - 11S/95 (1964) (Report of the Panel adopted 16 November 1962) at [13]; United States Manufacturing Clause GATT BISD 31th Supp 74 GATT DOC L/5609 - 31S/74 (1984) (Report of the Panel adopted on 15/16 May 1984).

${ }^{30}$ Contracting Parties Ninth Session Report of Review Working Party IV on Organizational and Function Questions GATT DOC L/327 (22 February 1955) at 63.

${ }^{31}$ Ibid.

${ }^{32}$ Council of Representatives Minutes of Meeting - Held in the Centre William Rappard on 4 May 1988 GATT DOC C/M/220 (8 June 1988) at 35-36.

${ }_{33}$ Council of Representatives Minutes of Meeting - Held in the Centre William Rappard on 22 September 1988 GATT DOC C/M/224 (17 October 1988) at 19.
} 
However, in the US - Suspension of Obligations case, the Working Party was instructed by the contracting parties to investigate the appropriateness of the measure which the Netherlands government proposed to take, having regard to its equivalence to the impairment suffered by the Netherlands as a result of the United States restriction. ${ }^{34}$ Provided that, the Working Party stated there were two issues to be considered. The first was whether in the circumstances, the measure proposed was appropriate in character; and the second was whether the extent of the retaliation proposed was reasonable, having regard to the impairment suffered. ${ }^{35}$ In short, the 1952 Working Party noted that "appropriate" in the context of Article XXIII referred to the character of the proposed measure and that the amount equivalent to the level of the impairment suffered was the standard to be fulfilled. ${ }^{36}$ By citing Hudec's book, Palmeter and Alexandrov point out the explanation of the Chairman of the Working Party that the word "appropriate" in Article XXIII meant more than just "reasonable" as it required the Working Party to take into account the desirability of limiting such action to the best calculated in the circumstances to achieve the objective. ${ }^{37}$

Why did the Working Party believe that it was important to limit the sanction? What is the objective that was intended to be achieved? Kenneth Dam provides the best answer for these questions by arguing that nowhere in GATT dispute settlement provisions could one find a reference to a punitive sanction for non-performance. ${ }^{38}$ Dam notes that the principle, that the GATT as a whole is a system of reciprocal rights and obligations to be maintained in balance, means that the remedy provision is not understood in terms of sanctions; rather it is a system of reciprocal rights and obligations. Consequently, a failure to respect a tariff concession is not a transgression to be punished, but rather an event giving injured parties the privilege of suspending reciprocal concessions. ${ }^{39}$ Dam states that the best example to support the argument underlying this principle is that the main interest of GATT is to make as many agreements to

\footnotetext{
${ }^{34}$ US - Suspension of Obligations, above n 20, at [2].

${ }^{35}$ Ibid, at [3].

${ }^{36}$ Palmeter and Alexandrov, above ch 1, n 63, at 648-649.

${ }^{37}$ Ibid, at 649.

${ }^{38}$ Dam, above n 1, at 351-352.

${ }^{39}$ Ibid, at 352.
} 
reduce tariffs as possible, instead of assuring all commitments made are carried out. ${ }^{40}$ Therefore, punitive sanctions, arguably, might lessen contracting parties' interest in agreeing to further tariff concessions.

\section{$4 \quad$ An overview of WTO retaliation}

The general provisions concerning the procedures of retaliation under the WTO dispute settlement system are governed under the DSU. The retaliation stage may start following the lack of implementation by the violator state of recommendations or rulings within a reasonable time. Article 22 of the DSU provides the injured party a right either to negotiate mutually agreed compensation or to request authorisation for retaliation for the violator state's lack of compliance within a reasonable period of time. In practice, because it is hard to achieve mutually agreed compensation, the parties to a dispute often directly request the authorisation to retaliate.

The assessment of retaliation in this section is divided into two main parts. The first part explains the characteristics and substantive rules of retaliation under the DSU. The second part assesses the countermeasures under the SCM agreement.

(a) The basic features of WTO retaliation

This part refers to the DSU, panels and the Appellate Body as well as the arbitrators' decisions to explain the basic characteristics and features of WTO retaliation, for instance whether it is prospective or retroactive in nature, or what the limitation level of retaliation is.

(i) Retaliation is the last resort and the sole remedy against non-compliance

The DSU provides retaliation as the last resort remedy, and this has two meanings. Firstly, it is not the first preference in settling a dispute, and secondly there are no other remedies available afterwards. The first meaning is demonstrated under Article 3.7 of the DSU which established the remedial hierarchy. The order of preference is as follows: (1) bilateral settlement;

\footnotetext{
${ }^{40} \mathrm{Ibid}$, at 80 . Dam states that it is better that 100 commitments should be made and that 10 should be withdrawn than that only 50 commitments should be made and that all of them should be kept.
} 
(2) withdrawal of inconsistent measures; (3) compensation; and (4) retaliation. ${ }^{41}$ From this we can conclude that the primary objective of parties to a dispute is the withdrawal of the inconsistent measures and only in special circumstances do they have to resort to retaliation. The second meaning is revealed in Article 22.2 of the DSU. When the violator state fails to comply within a reasonable period of time (non-compliance), there are only two remedies available for the injured state: either compensation or the suspension of concessions or other obligations. The DSU does not provide any form of remedy where retaliation fails to cause the violator state to remove its inconsistent measures. The article also reveals that the only form of retaliation under the DSU is the suspension of concessions or other obligations.

One of the issues in the EC-Commercial Vessels case was whether attempts to redress non-compliance by taking other WTO consistent measures would contravene the DSU. ${ }^{42}$ The panel considered that by adopting the TDM regulation (a measure to redress the violation) in response to Korea's violation of the SCM Agreement without first resorting to the DSU, the European Communities have acted unilaterally, and thus, such measures contravened Article 23.1 of the DSU. ${ }^{43}$ Sebastian examines the panel's reasoning more broadly by arguing that this reasoning also implies that suspension under non-WTO treaties, such as an expropriation of the Bilateral Investment Treaty, if taken to redress WTO violation, could contravene Article 23.1 of the DSU. ${ }^{44}$

(ii) Retaliation is temporary and prospective in nature

The temporary nature of retaliation is related to the fact that its application is conditional on the removal of the inconsistent measures by the violator state. In short, retaliation remains in place until there is compliance. Bermann criticises that the lack of an explicit post-retaliation

\footnotetext{
${ }^{41}$ McGivern, above ch 1, n 49, at 142.

${ }^{42}$ European Communities - Measures Affecting Trade in Commercial Vessels WTO DOC WT/DS301/R (2005) (Report of the WTO Panel) [EC-Commercial Vessels (Panel)].

${ }^{43}$ Ibid, at [7.220]-[7.222].

${ }^{44}$ Thomas Sebastian "The Law of Permissible WTO Retaliation" in Chad Brown and Joost Pauwelyn (eds) The Law, Economics and Politics of Retaliation in WTO Dispute Settlement (Cambridge University Press, 2010) 89 at 90-91 [“The Law of Permissible WTO Retaliation"].
} 
complaint procedure under the DSU could result in never-ending retaliation. ${ }^{45}$ The $E C-$ Hormones dispute is one example. In this case, there was a disagreement between the European Communities and the United States and Canada concerning compliance by the European Communities, which resulted in the United States and Canada continuing to impose retaliation. Consequently, the European Communities brought a new dispute before the panel against the United States and Canada's continued suspension. ${ }^{46}$

Nothing in the DSU explicitly states that retaliation is a prospective remedy. However, Article 3.7, 19.1 and 21.3 of the DSU envisage a panel or Appellate Body's recommendation to be prospective only. ${ }^{47}$ In general, Article 3.7 prescribes the hierarchy of remedies; Article 19.1 provides that the dispute panel and/or Appellate Body would recommend that the violator state brings its inconsistent measures into compliance; and Article 21.3 stipulates a reasonable period of time for the violator state to bring its inconsistent measures into compliance. If these three articles are read jointly, they implicitly limit the scope of what the injured state may request. The injured state cannot request that the violator state be required to make reparation for injury caused by the inconsistent measure which predates the expiry of a reasonable period of time. ${ }^{48}$ Put differently, retaliation only covers the time period after the DSB grants authorisation, not the whole period of the inconsistent measure applied. ${ }^{49}$

Under GATT/WTO case law, however, some panel's decisions provided retroactive remedies. During the GATT era, for instance, several disputes which were related to subsidies and countervailing measures and anti-dumping resulted in the granting of retrospective

\footnotetext{
45 Suzanne Bermann "EC-Hormones and the Case for an Express WTO Postretaliation Procedure" (2007) 107 Colum L Rev 131.

${ }^{46}$ The United States - Continued Suspension of Obligations in the EC - Hormones Dispute WTO DOC WT/DS320/R (2008) (Report of the WTO Panel) [US - Hormones Suspension (Panel)] and Canada - Continued Suspension of Obligations in the EC - Hormones Dispute WTO DOC WT/DS321/R (2008) (Report of the Panel) [Canada-Hormones Suspension (Panel)].

${ }^{47}$ Gavin Goh and Andreas R Ziegler "Retrospective Remedies in the WTO after Automotive Leather" (2003) 6(3) JIEL 545 at 555-556.

${ }^{48}$ Sebastian "The Law of Permissible WTO Retaliation", above n 44, at 93.

${ }^{49}$ A Handbook on the WTO Dispute Settlement System, above ch 1, n 4, at 82.
} 
remedies. ${ }^{50}$ Those cases were Canada-Manufacturing Beef CVD, ${ }^{51}$ US - Canadian Pork, ${ }^{52}$ US - Softwood Lumber II, ${ }^{53} \mathrm{NZ}$ - Finnish Transformers, ${ }^{54}$ US - Cement,${ }^{55}$ and US - Swedish Steel. ${ }^{56}$

Under the WTO dispute settlement scheme, Brazil - Aircraft and Guatemala - Cement are two cases where the complaining party requested that the panel awards a retrospective remedy. ${ }^{57}$ Additionally, in the Australia - Automotive Leather (Article 21.5 - US) case, despite the fact that Australia and the United States requested the withdrawal of the subsidy in a prospective way, the panel provided that the prospective remedy proposed by Australia would be ineffective. Thus, the panel concluded that repayment in full of the prohibited subsidy was necessary in order to "withdraw the subsidy" in this case. ${ }^{58}$ The Australia-Automotive Leather (Article 21.5 - US) panel report received many criticisms from WTO Members. ${ }^{59}$

\footnotetext{
${ }^{50}$ Patricio Grané "Remedies under WTO Law" (2001) JIEL 755 at 764.

${ }^{51}$ Canada - Imposition of Countervailing Duties on Imports of Manufacturing Beef from the EEC GATT DOC DS SCM/85 (1987) at [15] (Report by the Panel unadopted). The Panel suggested that "the Committee recommend that Canada terminate the outstanding countervailing duty order on manufacturing beef from the EEC, and that it refund any duties collected under that order."

${ }^{52}$ United States - Countervailing Duties on Fresh, Chilled, and Frozen Pork from Canada GATT BISD 38th Supp 30 GATT DOC DS7/R - 38S/30 (1990) at [5.2] (Report of the Panel adopted on 11 July 1991). The Panel recommended that "the CONTRACTING PARTIES request the United States to either reimburse the countervailing duties corresponding to the amount of the subsidies granted...or to make a subsidy determination which meets the requirements of Article VI:3 and reimburse the duties to the extent that they exceed an amount equal to the subsidy so determined to have been granted to the production of pork."

${ }^{53}$ United States - Measures Affecting Imports of Softwood Lumber from Canada GATT BISD 40th Supp 358 GATT DOC SCM/162 (1993) at [415] (Report of the Panel adopted by the Committee on Subsidies and Countervailing Measures on 27 October 1993). The Panel recommended the United States to refund the cash deposits made during the period of application of its inconsistent measures.

${ }^{54}$ New Zealand - Import of Electrical Transformers from Finland GATT BISD 32th Supp 55 GATT DOC L/5814 (1985) at [4.11] (Report by the Panel adopted on 18 July 1985). The Panel proposed to the Council that it addresses to New Zealand a recommendation to revoke the anti-dumping determination and to reimburse the antidumping duty paid.

${ }^{55}$ United States - Anti-Dumping Duties on Gray Portland Cement and Cement Clinker from Mexico GATT DOC ADP/82 (1992) at [6.2] (Report of the Panel unadopted). The Panel recommended the United States to revoke the anti-dumping duty order and to reimburse any anti-dumping paid.

${ }^{56}$ United States - Imposition of Anti-Dumping Duties on Imports of Seamless Stainless Steel Hollow Products from Sweden GATT DOC ADP/27 (1990) at [5.24] (Report of the Panel unadopted). The Panel suggested the United States to revoke the anti-dumping duties imposed and to reimburse the anti-dumping paid. The United States did not agree with the retrospective corrective measures and refused to adopt the report.

${ }^{57}$ Brazil - Export Financing Program for Aircraft WTO DOC WT/DS46/R (1999) (Report of the WTO Panel); Guatemala - Anti-dumping Investigation Regarding Portland Cement from Mexico WTO DOC WT/DS60/R (1998) (Report of the WTO Panel). Nevertheless in both cases, panels did not issue specific recommendations requested by those complaining parties.

${ }^{58}$ Australia - Subsidies to Producers and Exporters of Automotive Leather (Recourse to Article 21.5 of the DSU by the United States) WTO DOC WT/DS126/RW (2000) at [6.47]-[6.48] (Report of the Panel).

${ }^{59}$ Dispute Settlement Body Minutes of Meeting - Held in the Centre William Rappard on 11 February 2000 WTO DOC WT/DSB/M/75 (7 March 2000) at 5-9.
} 
Although no provision under the DSU explicitly prohibits retroactive remedies and several panels' decisions provide for such retroactive relief, retroactive remedies, arguably, are not preferred by WTO Members. Palmeter and Mavroidis refer to the phrase "today's complainant may be tomorrow's respondent" to explain why Members dislike retroactive remedies. ${ }^{60}$ Additionally, Grané argues from the perspective of Members' sovereignty that such sovereignty would be impinged by stringent corrective remedies, which might result in states losing their interest in staying inside the system. ${ }^{61}$ Recommendations for retroactive remedies are actually quite uncommon and depart from general practice in GATT and WTO. For example, the GATT Panel in the Norway - Trondheim case concluded that no GATT practice instituted "retroactive compensation". 62 The WTO panel in US - Certain Products from the EC also stated that "retroactive remedies are alien to the long established GATT/WTO practice where remedies have traditionally been prospective." 63

(iii) Retaliation consists of a certain magnitude and is not punitive

The WTO provides several standards to determine the magnitude of retaliatory measures. Firstly, Article 22.4 of the DSU stipulates that retaliation shall be equivalent to the level of nullification or impairment. Secondly, Article 4.10 of the SCM Agreement provides for an "appropriate" standard for countermeasures against prohibited subsidies. Thirdly, Article 7.9 of the SCM Agreement states that the countermeasures in the case of actionable subsidies must be commensurate with the degree and nature of the adverse effects. Fourthly, Article XXVIII:3(b) of the GATT provides the standard of substantially equivalent concessions on retaliatory withdrawal measures.

\footnotetext{
${ }^{60}$ Palmeter and Mavroidis, above ch 1, n 18, at 165. For instance, in Australia-Automotive Leather (Article 21.5 $U S$ ), even though the United States was the winner, it provided a statement that it "did not agree with every word of the Panel Report" and that "the Panel's remedy went beyond that sought by the United States". See WT/DSB/M/75, above $\mathrm{n} 59$ at 5.

${ }^{61}$ Grané, above n 50, at 772.

${ }^{62}$ Norway - Procurement of Toll Collection Equipment for the City of Trondheim GATT BISD 40th Supp 319 GATT DOC GPR.DS2/R (1992) at [3.37] (Report of the Panel adopted by the Committee on Government Procurement on 13 May 1992).

${ }^{63}$ US - Certain EC Products (Panel), above n 16, at [6.106].
} 
Retaliation under the WTO Agreement is not designed to be punitive. The availability of these standards is intended to limit retaliatory measures so that they do not become punitive sanctions. The non-punitive nature is primarily reflected in the "equivalent" standard under Article 22.4 of the DSU. The SCM Agreement also does not justify punitive sanction. Mavroidis notes that the definition of "proportionate" in the footnote to Article 4.10 of the SCM Agreements means not disproportionate, and therefore, has the reasonable interpretation that punitive damages are excluded. ${ }^{64}$

In practice, arbitrators in EC-Bananas (Article 22.6-EC) also considered that there is nothing in Article 22 that could be read as justifying punitive countermeasures. ${ }^{65}$ Moreover, in $U S-F S C$ (Article 22.6 - US) the arbitrators emphasised that nothing in the text or in the context of Article 4.10 of the SCM Agreement suggests an entitlement to punitive measures. ${ }^{66}$

(b) Three principles and calculation methods of retaliation under the DSU

There are two main things that are requested or challenged by parties to the dispute in Article 22.6 arbitral proceedings. The first relates to cross-retaliation, and the second relates to the determination of the level of retaliation. Hence, this part has two main points of discussion. Firstly, this part discusses three principles which the requesting party should seek to satisfy before it is entitled to do cross-retaliation. Secondly, this part explains the calculation methods of WTO retaliation such as the determination of counterfactual and the level of calculation.

Three principles of retaliation

Unlike its predecessor, the WTO has governed not only the area of goods but also services and intellectual property rights. Thus, considering the concessions or obligations to suspend, the DSU sets forth three main principles related to those areas under Article 22.3.

\footnotetext{
${ }^{64}$ Mavroidis "Between a Rock and a Hard Place", above ch 1, n 90, at 805-806.

${ }^{65}$ EC-Bananas III (US) (Article 22.6-EC), above ch 1, n 12, at [6.3].

${ }^{66}$ US - FSC (Article 22.6-US), above ch 1, n 13, at [5.62].
} 
The first principle is that the complaining party should first seek to retaliate with respect to the same sectors in which nullification or impairment has been found ${ }^{67}$ If the party considers that it is impracticable or ineffective to retaliate in the same sectors, the second principle applies which is that party may seek to retaliate in other sectors under the same agreement. ${ }^{68}$ If the complaining party considers that it is not practicable or effective to retaliate in other sectors under the same agreement, and the circumstances are serious enough, the third principle provides that the complaining party may retaliate under another covered agreement. ${ }^{69}$ In short, the three principles of retaliation are "same-sector" retaliation, "cross-sector" retaliation and "crossagreement" retaliation.

Moreover, the term "sector" means: ${ }^{70}$

(i) with respect to goods, all goods;

(ii) with respect to services, those identified in the current "Service Sectoral Classification List" (for instances business, communications, distribution, financial, health, and so forth);

(iii) with respect to TRIPS, each category of intellectual property rights covered in the first seven sections of Part II (for example copyright, patents, trademarks, geographical indications and so forth) or the obligations under Part III (enforcement obligations) or IV (acquisition and maintenance of intellectual property rights and related inter partes procedures) of the TRIPS Agreement.

In applying these three principles for cross-retaliation, the complaining party shall take into account: ${ }^{71}$

(i) the trade in the sector or under the agreement under which the violation or other nullification or impairment has been found, and the importance of such trade to the complaining party;

\footnotetext{
${ }^{67}$ The DSU, art 22.3(a).

${ }^{68}$ Ibid, art 22.3(b).

${ }^{69}$ Ibid, art 22.3(c).

${ }^{70} \mathrm{Ibid}$, art 22.3(f)(i)(ii)(iii).

${ }^{71}$ Ibid, art 22.3(d). The cross-retaliation provision does not apply to the plurilateral agreement on government procurement (GPA), see the GPA, art XXII:7.
} 
(ii) the broader economic elements related to the nullification or impairment and the broader economic consequences of the retaliation.

As regarding "the importance of such trade" to the complaining party, arbitrators in $E C$ Bananas III (Ecuador) (Article 22.6 - EC) held that this criterion relates primarily to the trade nullified or impaired by the WTO inconsistent measures. ${ }^{72}$ Thus, in the arbitrators' view, the trade in its entirety (in this case, they are under the GATT and GATS) is of subsidiary importance. ${ }^{73}$ In contrast, the arbitrators in US - Gambling (Article 22.6 - US) held the view that "the ordinary meaning of subparagraph (d)(i) suggests that a consideration of the entirety of 'trade in the sector' under which a violation was found is pertinent". ${ }^{74}$ The arbitrators' view in US - Gambling (Article 22.6 - US), arguably, is more appropriate, because Article 22.3 paragraph 3(d)(i) does not distinguish between trade of primary and subsidiary importance and that the meaning of "sector" in paragraph 3(f)(i) with respect to goods is all goods. ${ }^{75}$

With regards to the "broader economic elements" and "broader economic consequences of the retaliation", the arbitrators in EC - Bananas III (Ecuador) (Article 22.6 - EC) stated that the former criterion primarily relates to the suffering of the complaining party as a result of the nullification or impairment. The latter criterion relates to the consequences not only for the respondent party, but also for the complainant party. ${ }^{76}$

Furthermore, the arbitrators in EC-Bananas III (Ecuador) (Article 22.6-EC) assessed what is meant by saying that retaliation in the same sector or the same agreement "is not practicable or effective" and that "the circumstances are serious enough" under Article 22.3 paragraph (b) and (c). In assessing the former question with regards to goods, Ecuador argued that most of its imports of goods from the European Communities were of primary goods or investment goods rather than consumer goods. Therefore, Ecuador stated that retaliation in the

\footnotetext{
${ }^{72}$ EC-Bananas III (Ecuador) (Article 22.6-EC), above ch 1, n 12, at [84].

${ }^{73}$ Ibid at [128].

${ }^{74}$ US - Gambling (Article 22.6-US), above ch 1, n 12, at [4.33].

${ }^{75}$ Shadikhodjaev, above $\mathrm{n} 7$, at 71 .

${ }^{76}$ EC-Bananas III (Ecuador) (Article 22.6-EC), above ch 1, n 12, at [71].
} 
goods sector would not be practicable or effective, and would harm Ecuador more than the European Communities. ${ }^{77}$

The arbitrators considered the effects on primary and investment goods and on consumer goods separately. With respect to primary and investment goods, the arbitrators stated that in the absence of alternative sources of supply at similar prices, Ecuadorian industry would be hurt by a suspension of these products. ${ }^{78}$ The arbitrators concluded that the European Communities did not prove that retaliation under the GATT with respect to primary and investment goods is both "practicable and effective" for Ecuador. ${ }^{79}$ However, the arbitrators noted that it was both "practicable and effective" for Ecuador to suspend imports of "consumer goods" because the suspension would not cause any direct adverse effects on Ecuadorian domestic industries. ${ }^{80}$ As regards services, the arbitrators found that Ecuador's concessions on services were limited. Thus, the arbitrators concluded that a suspension of services is not practicable or effective for Ecuador. $^{81}$

Additionally in relation to the phrase "circumstances are serious enough", the arbitrators stated that Article 22 does not provide any threshold for determining when circumstances can be considered "serious" enough to justify retaliation. Thus, the arbitrators utilised the ordinary meaning of "serious" and contextual guidance under Article 22.3(d) of the DSU. ${ }^{82}$ Accordingly, to be considered as serious, circumstances must reach a certain degree of importance that is manifested in the provision of Article 22.3(d). ${ }^{83}$

(ii) Calculation of the level of suspension

In most arbitration proceedings the arbitrators, by referring to Article 22.4 of the DSU, determined that the level of suspension shall be equivalent to the level of nullification or impairment. Accordingly, the arbitrators need to determine at first the level of nullification and

\footnotetext{
${ }^{77}$ Ibid, at [89].

${ }^{78} \mathrm{Ibid}$, at [92]-[95].

${ }^{79}$ Ibid, at [96].

${ }^{80} \mathrm{Ibid}$, at [100]-[101].

${ }^{81}$ Ibid, at [103]-[105].

${ }^{82}$ Ibid, at [81], [121].

${ }^{83}$ Shadikhodjaev, above n 7, at 71-72.
} 
impairment. To calculate the level of nullification or impairment, the arbitrators have to compare the trade value of the current WTO-inconsistent situation with the trade value of a "counterfactual" WTO-consistent situation. The counterfactual is a trade value in a situation that arguably would exist if the violator state had removed the WTO-inconsistent measure within a reasonable period of time.

(iii) Determining the counterfactual and the method of calculation

The determination of the counterfactual is a hypothetical analysis by the arbitrators. McGriven notes that the use of the counterfactual can involve a fair degree of subjective assessment by the arbitrators. ${ }^{84}$ Hudec also states that by simply announcing the "correct" methodology and number with little explanation, the arbitrators' panel reports might be disappointingly obscure; however, as long as the parties are willing to accept the decision, it is politically acceptable. ${ }^{85}$

The choice of counterfactual in practice has been quite varied. In EC - Bananas III (US) (Article 22.6-EC), the arbitrators selected a counterfactual (a global tariff quota and unlimited access for ACP bananas at a zero tariff) that was quite different from several counterfactuals proposed by the United States and provided no explanation for their choice of counterfactual. ${ }^{86}$ The arbitrators in EC - Bananas III (Ecuador) (Article 22.6 - EC) selected the same counterfactual as the one in EC - Bananas III (US) arbitration to ensure consistency and to prevent double-counting on the nullification or impairment carried by the United States. ${ }^{87}$

In both EC - Hormones (Article 22.6) disputes, the arbitrators focused on the trade foregone due to the continuance of the existing ban on hormone-treated beef. The arbitrators calculated the detrimental effects by comparing annually the value of hormone-treated beef exports under the current European Communities-inconsistent measure with the value of hormone-treated beef exports which would take place in the European Communities if the

\footnotetext{
${ }^{84}$ McGriven, above ch 1, n 49, at [151].

${ }^{85}$ Ibid, at [151]; Hudec "Broadening the Scope of Remedies", above ch 1, n 14, at 391.

${ }^{86}$ EC-Bananas III (US) (Article 22.6 - EC), above ch 1, n 12, at [7.4]-[7.8].

${ }^{87}$ EC-Bananas III (Ecuador) (Article 22.6 - EC), above ch 1, n 12, at [166].
} 
measure was WTO-consistent. ${ }^{88}$ In these disputes, however, there were two possible relevant counterfactuals. First, there was the situation where the European Communities had withdrawn its inconsistent measure, and second, there was a situation where the European Communities maintained its import ban but supported it with a proper risk assessment as required by the SPS Agreement. The arbitrators selected the first counterfactual, and the European Communities did not contest it. ${ }^{89}$ However, it is arguable that the choice of this counterfactual scenario affected the calculation of the level of nullification or impairment. ${ }^{90}$

The counterfactual in US-Byrd Amendment (Article 22.6-US) was the trade effect of the CDSOA disbursements. Here the arbitrators departed from the counterfactual applied in $E C-$ Bananas III and EC - Hormones by applying an economic model, rather than the value of the violation itself, to assess to what extent the payments nullified and impaired benefit to the injured party. ${ }^{91}$ In this case, the arbitrators also refused to include the calculation of the detrimental effects experienced by the third country entities. The arbitrators stated that "a Requesting Party may only request suspension of concessions or other obligations with respect to the trade effect caused by disbursements under the CDSOA relating to its own exports". 92

In US - 1916 Act (Article 22.6 - EC), the arbitrators refused the European Communities' proposal on "mirror" regulation. The arbitrators argued that it is impossible to determine the WTO-consistency of a "qualitative equivalence", thus it is essential to determine the trade or economic effect of the 1916 Act on the European Communities in numerical or monetary terms (quantitative equivalence). ${ }^{93}$ This case is quite unique, since after a reasonable period of time, no order under the 1916 Act had been in place against the European Communities' products. Thus, the arbitrators provided that the calculation method was to rely on the future situations. These were any final judgments that would be made against the European Communities' entities under the 1916 Act, and the situation that an award would be payable by the European Communities'

\footnotetext{
${ }^{88}$ EC - Hormones (Canada) (Article 22.6 - EC), above ch 1, n 12, at [42]; EC - Hormones (US) (Article 22.6 $E C)$, above ch $1, \mathrm{n} 12$, at [43].

${ }^{89}$ Ibid, at [37]; Ibid, at [38].

${ }^{90}$ Sebastian "The Law of Permissible WTO Retaliation”, above n 44, at 101-102; Shadikhodjaev, above n 7, at 125.

${ }^{91}$ US - Byrd Amendment (Article 22.6 - US), above ch 1, n 12, at [3.77].

${ }^{92}$ Ibid, at [4.16].

${ }^{93}$ US - 1916 Act (Article 22.6 - EC), above ch 1, n 12, at [5.20]-[5.23].
} 
entities to settle claims under the Act. ${ }^{94}$ The arbitrators also refused to include the "chilling effect" of the 1916 Act and the litigation cost in the calculation. ${ }^{95}$

The counterfactual in US - Gambling (Article 22.6 - US) was rather controversial. In this case, the arbitrators provided that only a "counterfactual that allowed remote gambling on horseracing but disallowed other types of gambling is plausible."96 By allowing the remote gambling on horseracing as the counterfactual, the arbitrators provided a WTO-inconsistent counterfactual scenario. Sebastian argues that it is hard to reconcile the United States position that remote gambling must be banned to protect public morals with the counterfactual that permitted remote gambling on horseracing. ${ }^{97}$ Thus, Ehring writes that the US - Gambling arbitration proceeding was a judicial disaster. ${ }^{98}$

\section{$5 \quad$ Countermeasures under the SCM Agreement}

The Agreement on Subsidies and Countervailing Measures (the SCM Agreement) provides rules on subsidies and countervailing duties under multilateral trade agreements. A subsidy under the SCM Agreement consists of three main elements which are as follows: (i) a financial contribution (such as a direct transfer of funds, a potential direct transfer of funds or liabilities, government revenue foregone or not collected, the provision by a government of goods or services other than general infrastructure, the purchase by a government of goods, government payments to a funding mechanism or entrusts or direction of a private body); (ii) by a government or any public body; and (iii) conferring a benefit. ${ }^{99}$ The Agreement also distinguishes between three types of subsidies: prohibited, actionable and non-actionable subsidies. ${ }^{100}$ Prohibited subsidies are those contingent upon export performance or upon the use

\footnotetext{
${ }^{94}$ Ibid, at [5.45], [5.58].

${ }^{95}$ Ibid, at [5.72], [5.78].

${ }^{96}$ US - Gambling (Article 22.6 - US), above ch 1, n 12, at [3.54].

${ }^{97}$ Sebastian "The Law of Permissible WTO Retaliation", above n 44, at 104.

${ }^{98}$ Lothar Ehring "The European Community's Experience and Practice in Suspending WTO Obligations" in Chad P Bown and Joost Pauwelyn (eds) The Law, Economics and Politics of Retaliation in WTO Dispute Settlement (Cambridge University Press, 2010) 244 at 261-264.

${ }^{99}$ The SCM Agreement, art 1.1.

${ }^{100}$ The third category, non-actionable subsidies, as from 1 January 2000 contains non-specific subsidies, thus it does not longer in effect.
} 
of domestic over imported goods. ${ }^{101}$ Export subsidies and import substitution subsidies are prohibited under the SCM Agreement. Outside these prohibited subsidies, most subsidies are actionable, which means that they are not prohibited but are subject to challenge in the case that they cause "adverse effects to the interests of other Members". ${ }^{102}$

The SCM Agreement also sets forth special rules for dispute settlement, including the countermeasures. Article 4.7 of the SCM Agreement provides that when a panel finds the measure in question to be a prohibited subsidy, the panel shall recommend that the subsidising Member withdraw the subsidy without delay. If the prohibited subsidy is not withdrawn, Article 4.10 of the SCM Agreement provides that the DSB shall grant authorisation to the complaining party to take appropriate countermeasures. Article 4.11 of the SCM Agreement refers to arbitration under Article 22.6 of the DSU to determine whether the countermeasures are appropriate. Footnote 10 of the SCM Agreement states that "this expression [appropriateness] is not meant to allow countermeasures that are disproportionate in light of the fact that the subsidies dealt with under these provisions are prohibited".

(a) The meaning of countermeasures

The SCM Agreement does not provide a clear definition concerning what "appropriate" and the countermeasures mean. Nevertheless, the meaning of "countermeasures" has been determined in practice. The arbitrators in US - FSC (Article 22.6 - US) stated that "the dictionary definitions suggest that a countermeasure is essentially by reference to the wrongful action to which it is intended to respond"; accordingly, this ordinary meaning suggests that "a countermeasure bears a relationship with the action to be counteracted, or with its effects". ${ }^{103}$ The arbitrators, thus, decided that the term "countermeasures" in the context of Article 4 of the SCM Agreement, is in line with its ordinary meaning and that these measures are "authorized to counteract...a wrongful action in the form of an export subsidy that is prohibited per se, or the effect, thereof." 104 Therefore, the arbitrators concluded that the countermeasures can be utilised

\footnotetext{
${ }^{101}$ The SCM Agreement., art 3.

102 Ibid, art 5.

${ }^{103}$ US - FSC (Article 22.6 - US), above ch 1, n 13, at [5.4].

${ }^{104}$ Ibid, at [5.5] (emphasis added).
} 
either to counter the measure at issue (neutralising the export subsidy), or to counteract its effect on the affected party, or both. ${ }^{105}$

Furthermore, although the DSU and the SCM Agreement use different terms for retaliation, the arbitrators in Brazil - Aircraft (Article 22.6 - Brazil) considered that the term “countermeasures" may also include suspension of concessions or other obligations. ${ }^{106}$ The arbitrators in Canada - Aircraft (Article 22.6 - Canada) decided the same thing by stating that there is no restriction on the types of countermeasures under Article 4.10 of the SCM Agreement, however Brazil in this case requested the suspension of tariff concessions and other obligations as the countermeasures. ${ }^{107}$

(b) What constitutes "appropriate"?

A comprehensive definition of "appropriateness" is essential to determine the level of countermeasures. The arbitrators in US - Cotton (Article 22.6 - US) stated that the permissible level of countermeasures is mainly defined through the term "appropriate" and the wording of footnote 9. ${ }^{108}$ What constitutes "appropriate" is quite unclear under the SCM Agreement. Nevertheless, arbitrators' decisions in several prohibited subsidies disputes elaborated on several elements of the "appropriate" standard.

(i) It mainly corresponds to the amount of subsidy rather than the harm that has occurred

Brazil - Aircraft (Article 22.6 - Brazil) was the first dispute where the meaning of "appropriate" became the primary issue before the arbitrators. The meaning of countermeasures was not the central issue because Canada requested countermeasures in the form of suspension of concessions or other obligations, and Brazil did not challenge this. ${ }^{109}$ However, Canada did not request authorisation for the level of nullification or impairment, but for the amount of the

\footnotetext{
${ }^{105}$ Ibid, at [5.6].

${ }^{106}$ Brazil - Aircraft (Article 22.6-Brazil), above ch 1, n 13, at [3.29].

${ }^{107}$ Canada-Aircraft II (Article 22.6 - Canada), above ch 1, n 13, at [footnote 82].

${ }^{108}$ US - Upland Cotton (Article 22.6 - US), above ch 1, n 13, at [4.43].

${ }^{109}$ Brazil-Aircraft (Article 22.6 - Brazil), above ch 1, n 13, at [3.28].
} 
prohibited subsidy. Canada argued that countermeasures are appropriate if they correspond to the amount of the prohibited subsidy granted. Brazil challenged Canada's approach and asserted that countermeasures should correspond only to the part of payments or supports used to "secure a material advantage in the field of export credit terms". ${ }^{110}$ The arbitrators stated that, with regard to footnotes 9 and 10, "the reference to the fact that subsidies dealt with are prohibited can most probably be considered more as an aggravating factor than as a mitigating factor". 111 Therefore, they favoured Canada's approach. The arbitrators concluded that when dealing with prohibited subsidies, an amount of countermeasures which corresponds to the total amount of the subsidy is "appropriate". 12 Palmeter and Mavroidis challenge this finding and argue that reference in footnotes 9 and 10 to the fact that the subsidies involved are prohibited does not constitute an aggravating or mitigating factor, but instead, the use of the term "prohibited" is more to distinguish prohibited subsidies from those that are actionable. ${ }^{113}$

The arbitrators in Canada - Aircraft (Article 22.6 - Canada) went further by finding that although the level of countermeasures is more appropriately determined on the basis of the amount of subsidies, the level of countermeasures does not have to be limited to such amount. ${ }^{114}$

(ii) It allows more leeway than the word "equivalent"

The arbitrators in Brazil - Aircraft (Article 22.6 - Brazil) noted that "equivalent" and "appropriate" should not be given the same meaning, and that instead, the term appropriate should give more leeway than the word "equivalent" in assessing the level of countermeasures. Although the countermeasures may be in the form of suspension of concession or other obligation, the arbitrators in determining the appropriate level of suspension stated that there is no legal obligation that the appropriate level of countermeasures should be based on the level of nullification or impairment, since there is no reference made to nullification or impairment in

\footnotetext{
${ }^{110}$ Ibid, at [3.30].

${ }^{111}$ Ibid, at [3.51].

112 Ibid, at [3.60].

${ }^{113}$ Palmeter and Mavroidis, above ch 1, n 18, at 292.

${ }^{114}$ Canada-Aircraft II (Article 22.6 - Canada), above ch 1, n 13, at [3.91].
} 
Article 4 of the SCM Agreement. ${ }^{115}$ In other words, the appropriate level of countermeasures might go beyond the level of equivalent.

(iii) It is expected to have the effect of inducing compliance

In four arbitral proceedings on prohibited subsidies disputes, the arbitrators acknowledged that a countermeasure is appropriate if it induces compliance. In Brazil-Aircraft (Article 22.6 - Brazil), the arbitrators examined the term "appropriate" by referring to its meaning in general international law and in the work of the International Law Commission (ILC) on state responsibility and thereby came to a similar conclusion to the arbitrator in EC-Bananas III (Article 22.6 - EC) that "a countermeasure is 'appropriate' inter alia if it effectively induces compliance." $" 116$

The arbitrators in US - FSC (Article 22.6 - US) noted two things in assessing what may be deemed "appropriate" countermeasures. Firstly, the subsidy at issue should be withdrawn; and secondly, countermeasures should contribute to the withdrawal of the prohibited subsidy without delay. ${ }^{117}$ Thus, the arbitrators in Canada - Aircraft (Article 22.6 - Canada), with regard to Canada's statement that it did not intend to withdraw the subsidy and to the finding in US - FSC (Article 22.6 - US) which stated that the prohibited subsidy should be withdrawn without delay, introduced an additional 20 per cent to the amount of the countermeasure in order to induce Canada to withdraw the subsidy. ${ }^{118}$

In US - Cotton (Article 22.6 - US), the most recent Article 22.6 arbitral proceeding, the arbitrators found that inducing compliance seems to be the common purpose of retaliation in the WTO dispute settlement system including Article 22.4 of the DSU, but that this "inducing compliance" purpose does not by itself provide specific indication as to the permissible level of countermeasures. ${ }^{119}$

\footnotetext{
${ }^{115}$ Brazil-Aircraft (Article 22.6-Brazil), above ch 1, n 13, at [3.48].

${ }^{116}$ Ibid, at [3.44].

${ }^{117}$ US - FSC (Article 22.6 - US), above ch 1, n 13, at [5.51]-[5.60].

${ }^{118}$ Canada-Aircraft II (Article 22.6 - Canada), above ch 1, n 13, at [3.106]-[3.107].

${ }^{119}$ US - Upland Cotton (Article 22.6 - US), above ch 1, n 13, at [4.112].
} 


\section{(iv) Not disproportionate}

Footnotes 9 and 10 of the SCM Agreement provide a substantive rule for the appropriateness standard of the countermeasures: it should not be disproportionate. However, the SCM Agreement does not provide further explanation concerning the meaning of disproportionate. Because of this uncertainty, the arbitrators in Brazil - Aircraft (Article 22.6 Brazil) encountered difficulty identifying the relationship between the second part of the sentence in the footnote ("in light of the fact that the subsidies dealt with under these provisions are prohibited") to the first part of the sentence ("this expression is not meant to allow countermeasures that are disproportionate"). The arbitrators in US - FSC (Article 22.6 - US) by referring to footnote 9 to Article 4.10 of the SCM Agreement, provided a more certain explanation concerning the text in the footnote 9 . The arbitrators found that the footnote requires them: ${ }^{120}$

...to maintain a congruent relationship in countering the measure at issue so that the reaction is not excessive in light of the situation to which there is to be a response. But this does not require exact equivalence - the relationship to be respected is precisely that of "proportion" rather than "equivalence".

Howse and Neven argue that the footnote can be read as setting an upper bound on the countermeasures, and at the same time, as emphasising the unlawful character of the prohibited subsidy; hence, it provides a warning against excessively low countermeasures. ${ }^{121}$

(c) Justification of the "amount of subsidy" approach

In most arbitral proceedings on prohibited subsidies, the arbitrators have provided a calculation of countermeasures that corresponds to the amount of the subsidy. Several commentators provide terms for this approach. For instance, Shadikhodjaev in his book utilises the term "violation value" approach, while Sebastian utilises the term "the amount-of-subsidy" approach, which is the opposite of the "equality-of-harm" approach under Article 22 of the DSU.

\footnotetext{
${ }^{120}$ US - FSC (Article 22.6-US), above ch 1, n 13, at [5.18].

${ }^{121}$ Howse and Neven, above ch $1, \mathrm{n} 103$, at 106.
} 
The arbitrators have provided various justifications to support the approach that they employed. Firstly, there was the nonexistence of a reference to the concept of nullification or impairment in Articles 3 and 4 of the SCM Agreement, in contrast to Article 22.4 of the DSU. ${ }^{122}$ Thus, the calculation of "appropriate countermeasures" might not be based on the equivalent standard to the harm approach under the DSU. Such a calculation is possible as the arbitrators in US - FSC (Article 22.6 - US) recalled that Article 4.10 and 4.11 of the SCM Agreement are special and additional rules; and according to Article 1.3 of the DSU such special rules and procedures are to prevail over the rules and procedures under the DSU. ${ }^{123}$

Secondly, the arbitrators provided a comparison between Article 4.10 and Article 7.9 of the SCM Agreement. The arbitrators stated that the term "appropriate countermeasures" under Article 4.10 for prohibited subsidies does not impose similar constraints to the term "commensurate with the degree and nature of the adverse effects determined to exist" under Article 7.9 for actionable subsidies. ${ }^{124}$ In other words, Article 7.9 provides a tighter restriction on calculation by imposing a requirement of proportionality between the countermeasures and the adverse effects of the subsidy. ${ }^{125}$

Thirdly, there is the justification under the concept of obligations erga omnes provided by the arbitrators in US - FSC (Article 22.6 - US). The arbitrators considered obligations under prohibited subsidies as obligations erga omnes that are owed to all Members. A breach of the obligation is considered a wrongful act against all Members; therefore the arbitrators concluded that "the United States has breached its obligations to the European Communities in respect of all money that it has expended". ${ }^{126}$ The arbitrators derived the notion of obligations erga omnes from general international law. The application of the concept of obligations erga omnes in this case is somewhat controversial. One of the issues is the insertion of general international law

\footnotetext{
${ }^{122}$ Brazil-Aircraft (Article 22.6-Brazil), above ch 1, n 13, at [3.46].

${ }^{123}$ US - FSC (Article 22.6-US), above ch 1, n 13, at [5.47].

${ }^{124}$ Brazil-Aircraft (Article 22.6 - Brazil), above ch 1, n 13, at [3.49].

${ }^{125}$ Sebastian "The Law of Permissible WTO Retaliation", above n 44, at 114; Shadikhodjaev, above n 7 , at 103.

${ }^{126}$ US - FSC (Article 22.6-US), above ch 1, n 13, at [6.10].
} 
concepts into WTO dispute settlement. ${ }^{127}$ In the DSB meeting, the United States addressed the arbitrator's declaration in paragraph 6.10 and noted "the dubious quality legal analysis which, without foundation in the DSU, incorrectly and inappropriately purported to import into WTO jurisprudence the concept of erga omnes." "28 Another issue is that the approach would not be proportional when there are multiple complainants seeking to take countermeasures. In US FSC (Article 22.6 - US), the arbitrators were helped by the fact that the European Communities was the sole complainant. However the arbitrators realised that the consideration might be different in the case of multiple complainants. ${ }^{129}$

\section{(d) Commensurate standard}

Article 7.10 of the SCM Agreement provides that the countermeasures are commensurate with the degree and nature of the adverse effects determined to exist. So far, there is only one dispute that has been brought to arbitral proceedings to determine the commensurate standard of countermeasures. In US - Cotton (Article 22.6 DSU and Article 7.10 SCM - US), the arbitrators examined the terms "commensurate", "the degree and nature", and "the adverse effects determined to exist" separately. The arbitrators stated that commensurate does not require exact equality between the two elements being compared. It connotes a less precise degree of equivalent than exact numerical correspondence. However, it indicates a relationship of correspondence and proportionality between two elements, and this correspondence might be qualitative and quantitative. ${ }^{130}$ The arbitrators' finding demonstrates that the "commensurate" standard demands a higher degree of correspondence than the "appropriate" standard, but provides more flexibility in calculation than the "equivalent" standard. Thus, the "commensurate" standard stands somewhere between the "appropriate" and "equivalent" standard.

\footnotetext{
${ }^{127}$ In the DSB meeting, the United States challenged the insertion or application of the rules of international law outside the customary rules of interpretation into the WTO dispute settlement. It stated that "[r]eliance on public international legal concepts outside of rules of interpretation was not permitted under either DSU provision, and the arbitrator had erred in importing this concept as a means to justify its award." See WT/DSB/M/149, above ch 1, n 124 , at para 20.

${ }^{128}$ Ibid.

${ }^{129} U S-F S C$ (Article 22.6 - US), above ch 1, n 13, at [6.27].

${ }^{130}$ US - Upland Cotton (Article 22.6 - US), above ch 1, n 13, at [4.39].
} 
Furthermore the "degree and nature" of adverse effects is needed in assessing the commensurateness of the proposed countermeasures. ${ }^{131}$ The "degree" of the adverse effect is a quantitative assessment, while the "nature" is more a qualitative assessment. A qualitative assessment makes the countermeasures standard more flexible or less stringent than the "equivalent" standard that requires only quantitative assessment. ${ }^{132}$ In the end, the arbitrators examined the term "the adverse effects determined to exist" by referring to the specific "adverse effects" within the meaning of Articles 5 and 6 of the SCM Agreement. ${ }^{133}$

\section{Summary}

The first part of this chapter discussed the notion of retaliation. It examined the basic features, nature and substantive rules of GATT/WTO retaliation. It also carried out an assessment of three principles of retaliation and the method of calculation employed by the arbitrators in determining the level of retaliation. Because this part is aimed to provide a basic/general understanding of what WTO retaliation is, it is also important to include the assessment of countermeasures under the SCM Agreement. As stated previously, retaliation and the countermeasures have similar forms and characteristics, and unless the SCM Agreement requires otherwise, several issues are applicable to both measures.

The subsequent part examines the shortcomings and problems encountered by retaliation. Due to these shortcomings and problems, retaliation has often been claimed harmful and ineffective by commentators and WTO Members.

\footnotetext{
${ }^{131}$ Ibid, at [4.47].

${ }^{132}$ Shadikhodjaev, above $\mathrm{n} 7$, at 111 .

${ }^{133}$ US - Upland Cotton (Article 22.6 - US), above ch 1, n 13, at [4.50].
} 


\section{The Shortcomings and Problems of Retaliation: Academic Perspectives and Practice}

Retaliation is normally in the form of suspension of concessions or other obligations. The suspension implies trade restrictions and seems to go against the basic trade liberalising principle of the WTO. One might question why the WTO provides trade restrictions as the remedy. To respond to this question, first we need to understand that WTO trade concessions are based on reciprocal exchange between Members. Consequently, if one breaks its promise, another Member is entitled to withdraw its promise too. Nonetheless, imposing a trade restriction with the intention to redress the injury suffered because of another trade restriction, is just like adding one problem to another problem. In short, retaliation measures are trade destructive; therefore, it by its nature produces harm and has negative effects on the retaliating state.

Part two of this chapter carries out an analysis of the shortcomings and problems of retaliation. These issues have been comprehensively discussed academically. Part A explores these academic views and highlights several arguments about what are considered as the major shortcomings and problems of retaliation. Part B deals with retaliation problems in practice. It refers to several retaliation disputes under Article 22.6 of the DSU, and elaborates on the shortcomings and problems encountered by the complainant and respondent states with regard to retaliation.

\section{A Academic Perspectives}

The effectiveness of retaliation has been challenged since GATT dispute settlement. Dam writes that the scheme of retaliation [the withdrawal of concessions or other obligations] creates paradoxical consequences in regard to one of the basic principles of GATT: the reciprocity principle. ${ }^{134}$ The concept of reciprocity underlies the notion of exchanging the obligations of each government to the agreement which involves a balance of benefits and cost. ${ }^{135}$ Dam points out that fortuitous protection can be provided by retaliation towards industries that do not

\footnotetext{
${ }^{134}$ Dam, above n 1, at 357 (emphasis added).

${ }^{135}$ Hudec "Broadening the Scope of Remedies", above ch 1, n 14 at 387.
} 
deserve such protection, while the injured industries and domestic customers may not gain any benefit from the remedy. ${ }^{136}$ Thus, Dam argues that Article XXIII gives a remedy without a right. ${ }^{137}$ Hudec affirms Dam's view by stating that the balancing rationale for retaliation is a fiction in economic terms because the injured state does not gain anything by raising tariff barriers, instead its customers are afflicted by such barriers. ${ }^{138}$

The shortcomings of retaliation continue under the WTO dispute settlement system. Bronckers and van den Broek write that the threat of retaliation has proven effective in placing pressure on a violator government to comply with its WTO obligations; however, in their view the WTO remedies system also suffers from several significant flaws. ${ }^{139}$ Considerable academic writings primarily point out the shortcomings of retaliation, which as follows.

\section{1 "Shooting [oneself] in the foot"}

"Shooting [oneself] in the foot" is a term utilised by some scholars and commentators in describing the self-defeating consequences of retaliation. ${ }^{140}$ This term explains that by imposing retaliation, the retaliating state could harm its own economy; this is because retaliation normally takes the form of increasing the tariff barriers (namely 100 per cent duties) on the violator state's products. For example the United States retaliated in the form of a 100 per cent duty on certain European Communities products, ranging from Italian scarves to French Roquefort cheese, against the European Communities ban on hormone-treated beef. ${ }^{141}$

By creating another trade barrier, retaliation results in a loss of welfare for the customers and industries of the retaliating state and distorts the market. ${ }^{142}$ For instance, customers in the retaliating state have to pay a higher price when the tariff on selected products is increased, and

\footnotetext{
${ }^{136}$ Dam, above $\mathrm{n} 1$, at 357.

${ }^{137}$ Ibid, at 358 .

${ }^{138}$ Hudec "Broadening the Scope of Remedies", above ch 1, n 14, at 388.

${ }^{139}$ Bronckers and van den Broek, above ch 1, n 24, at 101-106.

${ }^{140} \mathrm{Ibid}$, at 104; Spadano, above ch 1, n 140, at 533; Bermann, above n 45, at 148.

${ }^{141}$ Pauwelyn "Calculation and Design of Trade Retaliation", above ch 1, n 60, at 36.

${ }^{142}$ Cho, above ch $1, \mathrm{n} 25$, at 790.
} 
industries that need those imported products for their production process will face commercial difficulties. ${ }^{143}$

\section{Paradoxical to the basic principle of the WTO}

In the event of retaliation, the retaliating state generally imposes trade restrictions on imports from the violator state. A retaliatory measure in the form of additional custom duties is, arguably, contrary to the basic principle of the WTO trade liberalisation. In other words, many question the notion of "protectionism against protectionism".

The Report of the Meltzer Commission raised a similar concern, noting that "retaliation is contrary to the spirit of the WTO". ${ }^{144}$ Pauwelyn points out this paradox, by stating that it is an irony that the world body preaching trade liberalisation depicts trade protectionism [retaliation] as offering some kind of benefit that could neutralise the effect of illegal trade restrictions. ${ }^{145}$

\section{$3 \quad$ Imposing an inappropriate burden on innocent industries}

Retaliation is perceived as unfair by affected private parties or industries of the responding state. These parties or industries are not involved at all in the trade dispute; yet will suffer and have to carry an inappropriate burden as a result of trade retaliation. ${ }^{146}$ Bronckers and van den Broek point out that the objective of this scheme is to encourage the innocent bystanders to put more pressure on their non-complying government. ${ }^{147}$ Despite this objective, retaliation itself is perceived as an unfair remedy. Firstly, it provides fortuitous protection to industries that do not deserve such protection while leaving industries that have suffered from illegal measures uncompensated. Secondly, it affects parties or industries that are not involved in the particular trade dispute or breach.

\footnotetext{
${ }^{143}$ McGivern, above ch 1, n 49, at 153.

${ }^{144}$ The Report of the International Financial Institution Advisory Commission (March 2000) at 108. International Financial Institution Advisory Commission, chaired by Allan H Melzer, was a commission established by the United States Senate to make recommendations on future United States policies towards several international organisations including the WTO. See also McGivern, above ch 1, n 49, at 152.

${ }^{145}$ Pauwelyn "Enforcement and Countermeasures", above ch 1, n 84, at 343.

${ }^{146}$ Bronckers and van den Broek, above ch 1, n 24, at 103; Malacrida, above ch 1, n 28, at 11.

${ }^{147}$ Ibid, at 102-103.
} 


\section{$4 \quad$ Counterproductive for developing and least-developed countries}

Retaliation is also counterproductive for developing and least-developed country Members because it is hard for them to afford the cost of retaliation. For instance, they may have to eliminate their access to foreign products or make those products more expensive for their domestic customers. Alavi argues that it is difficult for African countries to retaliate against bigger trading states because such retaliatory measures would impede their trade and losses would exceed any possible gains. ${ }^{148}$ The fear of "shooting [oneself] in the foot", therefore, makes retaliation unappealing in the eyes of developing and least-developed countries.

\section{B Retaliation Issues from Case Studies}

To date, the DSB has authorised retaliation in nine disputes. ${ }^{149}$ Three among the nine are disputes in which retaliation under different sectors or agreements (cross-retaliation) has been requested and authorised. ${ }^{150}$ Retaliatory measures have several problematic aspects which are evident in practice. For instance, there was a disagreement between the United States and the European Communities in EC - Hormones on whether implementation had occurred so that retaliatory measures could be terminated. Therefore, some proposals have been offered to enhance the existing retaliation provision. These proposals are elaborated on the subsequent part below.

This part elaborates on three major issues regarding the imposition of retaliatory measures by the complainant Members. The issues are as follows:

\footnotetext{
${ }^{148}$ Alavi “African Countries and the WTO's Dispute Settlement Mechanism”, above n 3, at 34.

${ }^{149}$ EC - Banana III, EC - Hormones, Brazil - Aircraft, US - FSC, US - 1916 Act, Canada - Aircraft II, US - Byrd Amendment, US - Gambling, and US - Cotton.

${ }^{150}$ EC - Bananas III, US - Gambling and US - Upland Cotton.
} 
This problem occurred, for instance, in the US - Byrd Amendment case. The Continued Dumping and Subsidy Offset Act of 2000 (CDSOA), also known as the Byrd Amendment, ${ }^{151}$ provides for the distribution of collected antidumping and countervailing duties to the United States companies that brought and supported petitions for antidumping/countervailing investigations against foreign producers. The panel, in a decision which was upheld by the Appellate Body, found that the Byrd Amendment was inconsistent with the GATT, the AntiDumping Agreement and the SCM Agreement. Following the expiry of a reasonable period of time, the complainants proceeded to request the authorisation for retaliation, even though only the European Communities, Japan, Mexico and Canada imposed the retaliatory measures against the United States.

Nonetheless, the imposition of retaliatory measures by the retaliating states seemed to do little in inducing the United States to cease its inconsistent measures promptly. The US Congress passed the Deficit Reduction Act of 2005 which repealed the Byrd Amendment in February 2006. However the Act allowed for a two year transition. ${ }^{152}$ The complainant states denied the United States claim about compliance and asserted that the transitional provisions in the Act still permit distribution of antidumping and countervailing duties collected on goods that are imported into the United States before 1 October 2007 to eligible United States companies. ${ }^{153}$

Regardless of the sanctions imposed by the complaining Members and the fact that the United States administration strongly urged to repeal the Byrd Amendment, the strong support which the Byrd Amendment enjoyed in the Senate as well as the domestic support which it received from the companies which benefited from it, had made the repeal process difficult. Consequently, a long delay for the United States in implementing the WTO ruling was inevitable.

\footnotetext{
${ }^{151}$ US Public Law 106-387, above ch 1, n 44.

${ }^{152}$ European Union "US Congress Repeal Byrd Amendment but Allows for Transitional Period" (Press Release, 20 December 2006).

${ }^{153}$ Shadikhodjaev, above n 7, at 139.
} 
Another retaliation problem that occurs in practice is that parties to the dispute continue to disagree what constitutes compliance, and as a result, retaliatory measures remain in place longer than necessary. This has happened in the EC - Hormones case. The European Communities, by adopting a new directive, claimed that it had complied with the DSB recommendations and the WTO covered agreements, because the prohibition of certain hormones under the new directive was based on a comprehensive scientific assessment which was required by the SCM Agreement. ${ }^{154}$ However, the United States and Canada disagreed that the new directive was based on a scientific assessment and argued that it was still inconsistent with the European Communities obligations under the SPS Agreement. Therefore, both states insisted on maintaining their retaliatory measures. ${ }^{155}$ Subsequently, the European Communities brought a new complaint against the continued suspension of obligations by the United States and Canada. ${ }^{156}$

The EC - Hormones case demonstrates post-retaliation problems, particularly the disagreement on whether implementation has occurred, and when retaliatory measures should be terminated. This implementation disagreement and continued sanctions definitely prolong dispute, and in the end might undermine the purpose of "security and predictability" of the WTO dispute settlement system.

3 Lack of retaliating capacity for small developing countries and least-developed countries

The retaliating Member normally imposes retaliatory measures in the form of suspension of concessions or other obligations by increasing tariff barriers (for example 100 per cent tariff) against the products of violator states. Because retaliation is trade destructive, the retaliating state is also negatively affected by the measures. Therefore, for small developing-country and leastdeveloped country Members, imposing retaliatory measures is often not the best option.

\footnotetext{
${ }^{154}$ European Communities - Measures concerning meat and meat products (Hormones) - Communication from the European Communities WTO DOC WT/DS26/22, WT/DS48/20 (28 October 2003).

${ }^{155}$ Dispute Settlement Body Minutes of Meeting held on 7 November 2003 WTO DOC WT/DSB/M/157 (18 December 2003) at paras 30-31.

${ }^{156}$ US - Hormones Suspension (Panel), above n 46; Canada - Hormones Suspension (Panel), above n 46.
} 
Moreover, because of their small economy and trade, imposing retaliation under the same sectors by small-developing or least-developed countries would not produce harm or significant impact on the developed-country Members. ${ }^{157}$

To increase their bargaining leverage, less economically powerful Members requested an authorisation for cross-retaliation. The authorisation to cross-retaliate has arisen in three disputes: EC-Bananas III, US - Gambling and US - Upland Cotton. However from practice we can learn that not all developing countries are in the position to impose cross-retaliation effectively.

Antigua, for instance, requested an authorisation to cross-retaliate at first under GATS and TRIPS Agreement; however, in the end, it limited its request to the TRIPS Agreement only. At the time of writing, Antigua had not yet imposed any retaliation against the United States. It has chosen to pursue a negotiated solution with the United States. ${ }^{158}$ Given the huge asymmetry between the economic situations of the two countries, it is doubtful that the threat of suspension of TRIPS concessions would have any meaningful power to promote a more favourable settlement for Antigua. ${ }^{159}$ In contrast, in the US - Upland Cotton case, Brazil's threat to impose cross-retaliation under the TRIPS Agreement has successfully led to the temporary agreement between Brazil and the United States. Therefore we can conclude that the credible threat of retaliatory measures depends on the economy and market size of the retaliating state as well as its substantial interest in intellectual property rights.

157 Antigua highlighted its small economic capacity and tourism dependent economy, and because of that, the imposition of retaliation under the GATS would have "a disproportionate adverse impact" on Antigua while it would cause "virtually no impact" on the United States. See US - Gambling (Article 22.6-US), above ch $1 \mathrm{n} \mathrm{12,} \mathrm{at}$ [4.87].

${ }^{158}$ Mark E Mendel "Retaliation in the WTO: The Experience of Antigua and Barbuda in US - Gambling" in Chad P Bown and Joost Pauwelyn (eds) The Law, Economic and Politic of Retaliation in WTO Dispute Settlement (Cambridge University Press, 2010) 310 at 313.

${ }^{159}$ Frederick M Abbot "Cross-Retaliation in TRIPS: Options for Developing Countries" (International Centre for Trade and Sustainable Development Issue Paper No 8, April 2009) at 8. 


\section{Proposals to Enhance WTO Retaliation and the Criticisms}

The previous part of this chapter described the shortcomings and problems of retaliation. The harm caused by retaliation and its inability to induce compliance are, amongst others, considered to be the major shortcomings of WTO retaliation. Several reform proposals have been made to improve the performance of retaliation. This part explains several major proposals, including criticisms to these proposals.

\section{A Collective Retaliation}

Generally, collective retaliation would allow states which are not directly injured to impose retaliation collectively on a recalcitrant state in order to force it to cease its illegal measures. Some commentators support a collective retaliation proposal in light of the inability of smaller countries to engage effectively at the dispute settlement and enforcement level against bigger countries. ${ }^{160}$ The proposal of collective retaliation was first submitted by a group of developing states in 1965 . $^{161}$ The background of this submission was because the developing countries felt that bilateral retaliation only works effectively if it is used by two major players, which are the United States and the European Communities. ${ }^{162}$ During the WTO era, a group of least-developed countries also proposed collective retaliation in cases where the complainant was a least-developed country. ${ }^{163}$

Even though this proposal seems to bring more power to developing and least-developed countries in the enforcement level, several commentators express doubt that the proposal would be successful. Fukunaga, for instance, argues that this proposal is legally unsound and politically

\footnotetext{
${ }^{160}$ For instance, Udombana suggests collective countermeasures for African countries through African Union. See Udombana, above ch 1, n 39, at 1198-1199.

${ }^{161}$ Ad Hoc Group on Legal Amendments to the General Agreement Proposals for Amendments to the General Agreement - Note by the Secretariat GATT DOC COM.TD/F/W/1 (27 April 1965). See also: Robert E Hudec "The Adequacy of WTO Dispute Settlement Remedies: A Developing Countries Perspective" in Bernard M Hoekman, Aaditya Mattoo and Philip English (eds) Development, Trade, and the WTO: A Handbook (the World Bank, 2002) at 84 .

${ }^{162}$ Debra P Steger Peace through Trade: Building the World Trade Organization (Cameron May, 2004) at 248.

${ }^{163}$ TN/DS/W/17, above n 14; Dispute Settlement Body Special Session Negotiations on the Dispute Settlement Understanding - Proposal by African Group WTO DOC TN/DS/W/15 (25 September 2002); and Dispute Settlement Body Special Session Text for the African Group Proposals on Dispute Settlement Understanding Negotiations - Communication from Kenya WTO DOC TN/DS/W/42 (24 January 2003).
} 
unrealistic because the nature of WTO obligations is reciprocal; so the participation of other nonparty Members would induce disruption and increase tension rather than achieve implementation. ${ }^{164}$ Malacrida also notes a number of difficulties in implementing collective retaliation, such as the problem a developing country Member would face in convincing nonparty Members to participate in collective action due to the high cost of retaliation. ${ }^{165}$

\section{B Transferrable Retaliation}

During the DSU negotiations, Mexico proposed a concept that allows the right to suspend to be transferred to one or more Members. ${ }^{166}$ Diego-Fernandez argues that negotiable retaliation creates a market because it opens up the possibility to auction the right to retaliate to the rest of the Members. ${ }^{167}$ It also brings benefits in terms of inducing compliance; developing countries that are unable to utilise or impose retaliation might transfer the right to countries that are interested in exercising the right against the Member concerned. ${ }^{168}$

However, some commentators raise the question of why a country would buy the right to retaliate due to the fact that retaliation itself is harmful or problematic. Yenkong states it is hard to imagine that a country would want to buy trouble; it would be like shooting oneself in the foot. ${ }^{169}$ Malacrida suggests that the most probable reason for a Member to buy the right to retaliate is to provide temporary protection to its domestic interest groups against competition from the respondent state. However, since retaliation is only a temporary measure, the issue of lack of predictability emerges. ${ }^{170}$

\footnotetext{
${ }^{164}$ Fukunaga, above ch $1, \mathrm{n} 127$, at 425 . She suggests that collective retaliation is possible to be implemented when the obligation is owed to the international community as a whole or when it is established to protect the collective interest of the group of states.

${ }^{165}$ Malacrida, above ch 1, n 28, at 22.

${ }^{166}$ TN/DS/W/40, above ch 1, n 55.

${ }^{167}$ Diego-Fernandez, above n 3, at 241.

${ }^{168}$ Ibid.

169 Ngangjoh H Yenkong "World Trade Organization Dispute Settlement Retaliatory Regime at the Tenth Anniversary of the Organization: Reshaping the "Last Resort" Against Non-Compliance" (2006) 40(2) JWT 365 at 380-381.

${ }^{170}$ Malacrida, above ch 1, n 28, at 23.
} 


\section{Financial/Monetary Compensation}

The idea of adding monetary or financial compensation as one of the dispute settlement remedies emerged a long time ago. In 1965, alongside the collective retaliation proposal, GATT developing country parties also submitted the monetary compensation proposal. ${ }^{171}$ Hudec describes the reason behind this proposal being that developing countries perceived that illegal measures not only caused serious harm but also hampered their development process, and thus the forward-looking remedies would not be sufficient to cover all the damage. ${ }^{172}$ Therefore, developing countries claimed that they were entitled to be awarded retroactive monetary compensation that would be paid to the government economic development program rather than to private interests. ${ }^{173}$

Numerous commentators also suggest the application of financial or monetary compensation in the WTO dispute settlement remedies. Bronckers and van den Broek, for instance, strongly argue several advantages of monetary compensation, such as the fact that it is not trade restrictive, it helps to redress the injury of the country and/or private interests, it does not put a disproportionate burden on innocent bystanders, and it is a better device to induce compliance. ${ }^{174}$ Fukunaga also asserts one of the advantages of financial compensation is that it is permitted to be non-MFN compensation because its existence is not related to either import or export transactions or market access. ${ }^{175}$ At the time of writing, there were two cases where a deal related to financial matters was agreed upon by the parties to the dispute. Those cases are US Copyright Act and US - Upland Cotton.

There is no provision for financial compensation in the DSU; however, there is also nothing in the DSU that precludes compensation from being pecuniary. Furthermore, providing financial compensation as a temporary settlement should not lead to another violation of WTO

\footnotetext{
${ }^{171}$ COM.TD/F/W/4, above n 13; see also Report of the Ad Hoc Group on Legal Amendments to the General Agreement GATT DOC COM.TD/F/4 (4 March 1966).

${ }^{172}$ Hudec "Broadening the Scope of Remedies", above ch 1, n 14, at 383. However the monetary compensation proposal was not adopted.

173 Ibid.

${ }^{174}$ Bronckers and van den Broek, above ch 1, n 24, at 110-111.

${ }^{175}$ Fukunaga, above ch 1, n 127, at 415.
} 
law, or become another inconsistent measure that nullifies or impairs other states' benefit. We take as examples the two cases (US - Copyright Act and US - Upland Cotton) where the United States provides a compensatory arrangement in the form of a financial settlement. Although both cases relate to a temporary settlement in a monetary form, the nature of the monetary arrangements in both cases is different. The lump-sum payment made by the United States "to a fund to be set up by performing rights societies in the European Communities" in US Copyright Act resembles financial compensation. ${ }^{176}$ The payment was made to compensate the royalty loss suffered by the European Communities intellectual property holders because of the application of Section 110(5) of the United States Copyright Act. ${ }^{177}$ In contrast, the funds or payments scheme made by the United States in US - Upland Cotton may constitute subsidy. It is a direct transfer of funds from the United States government to Brazilian cotton industries. ${ }^{178}$ In this situation it seems that the United States is subsidising Brazil cotton farmers in order to allow itself to maintain its subsidy to the United States' domestic cotton farmers. Such a payment scheme is likely to be challenged by other cotton-exporting Members.

Additionally, not all scholars are strong supporters of financial compensation. Mercurio, for example, argues that financial compensation is unpersuasive because only rich and developed countries can afford it, while poor countries are left in a helpless position. Further, it does not redress the injury of the aggrieved industry and it allows the continuance of a non-complying measure, and so forth. ${ }^{179}$

\footnotetext{
${ }^{176}$ WT/DS160/23, above ch 1, n 16.

${ }^{177}$ Bryan Mercurio "Retaliatory Trade Measure in the WTO Dispute Settlement Understanding: Are There Really Alternative?" in James C Hartigan (ed) Trade Disputes and the Dispute Settlement Understanding of the WTO: An Interdisciplinary Assessment (Emerald, 2009) 397 at 414-415 ["Retaliatory Trade Measure"].

${ }^{178}$ Randy Schnepf Brazil's WTO Case against the US Cotton Program (Congressional Research Service, 5 January 2011) at 28.

${ }^{179}$ Bryan Mercurio “Why Retaliation Cannot Replace Trade Retaliation”, above n 8, at 328-335.
} 


\section{Compulsory Compensation}

Since imposing retaliation may cause harm to retaliating states' economy and trade, several developing countries proposed compulsory compensation to an injured state instead of authorising retaliation. The proposal also suggested the inclusion of a temporary MFN waiver to developing countries in terms of compensation granted. ${ }^{180}$

Fukunaga demonstrates her disagreement with compulsory compensation by stating that it is not a realistic option because compensation always depends on voluntary payment by the respondent Member concerned. ${ }^{181}$

\section{E Automatically Permitting Cross Retaliation for Developing Countries}

This proposal came from a group of developing countries that suggested that in the case of a developing country Member being the complainant against a developed country Member, the developing country Member should be permitted to seek retaliation in the sector of its choice (any or all sectors). In other words, developing country Members should not need to go through Article 22.6 arbitral proceedings to request cross-retaliation. ${ }^{182}$

Malacrida comments that this proposal would minimise the cost of retaliation and make retaliation a more practical enforcement device for developing country Members. ${ }^{183}$ Although direct application of cross-retaliation would streamline procedures and reduce the cost of retaliation, the role of cross-retaliation as a practical enforcement device is still debatable. ${ }^{184}$

\footnotetext{
${ }^{180}$ Dispute Settlement Body Special Session Contribution of Ecuador to the Improvement of the Dispute Settlement Understanding of the WTO - Communication from Ecuador WTO DOC TN/DS/W/9 (8 July 2002); Dispute Settlement Body Special Session Negotiations on Improvement and Clarifications of the Dispute Settlement Understanding - Proposal by Mexico WTO DOC TN/DS/W/23 (4 November 2002).

${ }^{181}$ Fukunaga, above ch 1, n 127, at 412.

${ }^{182}$ Dispute Settlement Body Special Session Negotiations on the Dispute Settlement Understanding - Special and Differential Treatment for Developing Countries - Proposals on DSU by Cuba, Honduras, India, Indonesia, Malaysia, Pakistan, Sri Lanka, Tanzania and Zimbabwe WTO DOC TN/DS/W/19 (9 October 2002); Dispute Settlement Body Special Session Dispute Settlement Understanding Proposals: Legal Text - Communication from India on Behalf of Cuba, Dominican Republic, Egypt, Honduras, Jamaica and Malaysia WTO DOC TN/DS/W/47 (11 February 2003).

${ }^{183}$ Malacrida, above ch 1, n 28, at 20-21.

${ }^{184}$ Subramanian and Watal, above ch 1, n 140; van den Broek, above ch 1, n 139, at 154-155.
} 


\section{F Retroactive Remedies}

The WTO remedies under the current DSU are prospective in nature. In other words, the amount of retaliation does not cover the entire period the inconsistent measure has been applied. Even though in the past, particularly in the safeguard and anti-dumping disputes, panels have granted retroactive remedies, it is an uncommon practice in WTO dispute settlement.

Nevertheless, several Members, particularly the least-developed countries and the African group, support the inclusion of retroactive remedies in the dispute settlement system. ${ }^{185}$ Mexico also proposed that the level of nullification or impairment be calculated from the date of the imposition of the measure or request for consultation or establishment of panels. ${ }^{186}$ Commentators have brought forward various arguments concerning retroactive remedies. Yenkong argues that retroactive remedies may provide more pressure or incentive to comply. ${ }^{187}$ Moreover, Plasai suggests the introduction of an interim relief measure; this measure can be deemed to be a de facto retroactive remedy. ${ }^{188}$ Plasai adds that even without interim relief, retroactive remedies are significant in restoring the complaining party to the situation that existed before the violation. ${ }^{189}$ Nonetheless, Grané suggests that for the time being, WTO remedies should be prospective in nature. He argues that although retroactive remedies may provide more often incentive to comply, they may also encroach too much on the sovereignty of a state, and if a state feels the "system has gone too far" and is no longer protecting their interests, a reason to opt-out from the system is created. ${ }^{190}$

185 Dispute Settlement Body Special Session Text for LDC Proposal on Dispute Settlement Understanding Negotiations - Communication from Haiti WTO DOC TN/DS/W/37 (22 January 2003) at para VII; TN/DS/W/42, above $\mathrm{n} 165$, at para VIII.

${ }^{186} \mathrm{TN} / \mathrm{DS} / \mathrm{W} / 40$, above ch 1, n 55, at 5.

${ }^{187}$ Yenkong, above n 169, at 16.

${ }^{188}$ Virachai Plasai "Compliance and Remedies against Non-Compliance under the WTO System: Towards a More Balanced Regime for All Members" (International Centre for Trade and Sustainable Development, 2007) at 20.

${ }^{189}$ Ibid, at 20.

${ }^{190}$ Grané, above n 50, at 769-770. 


\section{Summary}

Numerous studies highlight the shortcomings and harms of retaliation, such as the notion that a complaining state is "shooting itself in the foot" when imposing retaliatory measures on a violator state. Furthermore, the Article 22.6 case studies provided us with an insight into several significant implementation issues; for instance the fact that, even though authorisation to retaliate may be granted, complaining states are either not utilising their right, or when they impose their right to retaliate, non-compliance continues or the inconsistent measure remains.

Because of these problems and shortcomings, retaliation is deemed ineffective in inducing compliance. Accordingly, several commentators, scholars and WTO Members have submitted various proposals to reduce the high cost of retaliation and to enhance its capacity as an effective enforcement device. However these proposals are also not free from criticisms and disapproval. These reform proposals were discussed in the third part of this chapter.

The subsequent chapter aims to assess the question of the effectiveness of retaliation

from another perspective or angle: the purpose of retaliation. What the significance of identifying the purpose of retaliation is, what the purpose of retaliation is and how to find it are the main issues of the following chapter. 


\title{
CHAPTER THREE
}

\section{THE QUEST TO DISCOVER THE PURPOSE(S) OF RETALIATION}

\begin{abstract}
"In other words, it is not completely clear what role is to be played by the suspension of obligations in the DSU and a large part of the conceptual debate that took place in these proceedings could have been avoided if a clear "object and purpose" were identified.",
\end{abstract}

"Determining whether a trade sanction is effective requires specification of its objectives. ",

\section{Overview}

As pointed out in the previous chapters, some commentators believe that WTO retaliation works in a frustrating way in non-compliance disputes, because even after the retaliating state has imposed the authorised retaliatory measures, the inconsistent measures still remain. Therefore, they have argued that retaliation is ineffective because it does little or nothing to induce compliance. ${ }^{3}$

The central point of this chapter lies in the question of effectiveness and the purpose(s) of retaliation. What does "effective" mean? Does effective have a similar meaning to compliance? When can an instrument be considered an effective device? Answering these questions is the first task in this chapter. The second task concerns the question of what the purpose(s) of retaliation is. Does retaliation aim solely on forcing the recalcitrant state to comply? Regardless of the answer, we know that the suspension has the effect of rebalancing mutual trade benefit. ${ }^{4}$

\footnotetext{
${ }^{1}$ US - Byrd Amendment (Article 22.6 - US), above ch 1, n 12, at [6.4].
}

${ }^{2}$ Charnovitz "Rethinking WTO Trade Sanctions", above ch 2, n 17, at 808.

${ }^{3}$ McGivern, above ch 1, n 49, at 152-153; Udombana, above ch 1, n 39, at 1187-1188; Gabriel L Slater "The Suspension of Intellectual Property Obligations under TRIPS: A Proposal for Retaliating against TechnologyExporting Countries in the World Trade Organization" (2009) 97 Geo L J 1365 at 1371; Spandano, above ch 1, n 140, at 512. Similarly, the arbitrators in the US - Gambling dispute stated that "the thrust of the 'effectiveness' criterion empowers the party seeking suspension to ensure that the impact of that suspension is strong and has the desired result, namely to induce compliance". Put differently, if the impact of the suspension (cross-retaliation) is not strong and does not induce compliance, in arbitrators' view, the suspension does not meet the "effectiveness" criterion. See US - Gambling (Article 22.6-US), above ch 1, n 12, at [4.84].

${ }^{4}$ A Handbook on the WTO Dispute Settlement System, above ch 1, n 4, at 81. 
As stated previously, one needs to identify the purpose of a rule or standard to measure the effectiveness of such a rule or standard. The examinations in this chapter demonstrate the relationship between the "effectiveness" and the "purpose". Accordingly, in order to determine the effectiveness of WTO retaliation, we need to identify the purpose(s) of retaliation.

To identify the purpose(s) of retaliation, this thesis undertakes the assessment through an interpretation of Article 22 of the DSU in accordance with the customary rules of interpretation. It assesses also remedies under public international law, academic debates and the decisions of arbitrators with regard to the purpose of retaliation.

\section{Definition of Effectiveness and the Importance of the Purpose}

It is necessary to clarify the meaning of effectiveness in the first place, as sometimes people get confused by the terms compliance, implementation and effectiveness. Based on the Cambridge Advanced Learner's Dictionary, "effective" means successful or achieving the result that you want. In other words, something is effective if it is adequate to accomplish its purpose or objective.

Effectiveness clearly is germane to the implementation and compliance discussion. In his foreword to a symposium on "implementation, compliance and effectiveness", Alvarez states that these three are related but distinct phenomena. ${ }^{5}$ Jacobson and Brown Weiss provide clear definitions of the three. Implementation refers to a method or measures by which states transform international accords into acceptable rules within their domestic law. The authors explain that some accords are self-executing, that is, they do not need domestic legislation to become effective, but most accords need domestic legislation to become effective. Compliance goes beyond implementation. It refers to whether states abide by procedural and substantive international obligations, regardless of what their domestic legislation provides. Effectiveness is related, but not identical to compliance. It goes beyond implementation and compliance to

\footnotetext{
5 Jose E Alvarez "Foreword Why Nations Behave” (1998) 19 Mich J Int'1 L 19 at 304.
} 
determine whether an international norm achieves its policy objective. ${ }^{6}$ Consequently, to respond to the question of whether retaliation is effective or not, it is necessary to identify the purpose of retaliation.

\section{A The Distinction between Compliance and Effectiveness}

People often assume that compliance can be equated with effectiveness. They perceive that a high level of compliance indicates the effectiveness of the rule, and vice versa. However, as previously stated, effectiveness goes beyond compliance, it is related but distinct.

An international law and international relations scholar, Raustiala, provides a credible analysis relating to the complex relationship between them. He argues that a high level of compliance is not necessarily an indication of high effectiveness, and vice versa, both compliance and effectiveness must be distinguished from each other. ${ }^{7}$ When the rule or standard matches with the current practice in a given state, compliance is automatic, but it does not mean that the rule or standard is effective. Raustiala employs speed limits as an example. He explains that people could easily comply with, for example, a 65 miles per-hour speed limit, but if this speed limit did not reduce accidents, it cannot be claimed that it is effective. In contrast, although speed limits are very seldom complied with strictly, if it has sufficient influence on driving behaviour and reduces traffic accidents to a certain degree, it is an effective device. ${ }^{8}$ Raustiala concludes that it is the "effectiveness" that provides causal linkage between a legal rule and behaviour. Compliance does not speak about causality, it merely identifies the conformity between the rule and the behaviour. ${ }^{9}$

\footnotetext{
${ }^{6}$ Harold K Jacobson and Edith B Weiss "A Framework for Analysis" in Edith B Weiss and Harold K Jacobson (eds) Engaging Countries: Strengthening Compliance with International Environmental Accords (MIT Press, 2000) 1 at 4-5. See also Alvarez, above n 5.

${ }^{7}$ Kal Raustiala "Compliance and Effectiveness in International Regulatory Cooperation" (2000) 32 Case W Res J Int'L L 387 at 388; Peter M Gerhart "Reflection: Beyond Compliance Theory - TRIPS as a Substantive Issue" (2000) 32 Case W Res J Int'l Law 352 at 363.

${ }^{8}$ Raustiala, above n 7, at 395-396.

${ }^{9}$ Ibid, at 398.
} 


\section{B "Effectiveness" Definition Employed}

As described previously, "effectiveness" is a concept that specifies the degree to which a rule or standard or an instrument achieves its purpose. Therefore, Gerhart notes that it is necessary to specify the goal or goals the rule or standard is intending to achieve in order to assess its effectiveness. ${ }^{10}$

Thomas Sebastian expressed a doubt that identifying the purpose would have a substantial implication in helping to resolve the issues faced by retaliation. He notes that the actual calculation method employed by the arbitrators does not rely on the purpose of retaliation, and that even identifying the purpose would not lighten the task of arbitrators as they would still encounter the practical difficulties of setting up the level of retaliation in accordance with the identified purpose. ${ }^{11}$ For instance, if retaliation has the purpose of inducing compliance, the arbitrators need information about the magnitude of the retaliatory measures that would be sufficient to force violator Members to comply, but this information is unattainable. Likewise, in order to rebalance the arbitrators need information about particular bilateral exchanges of promises between the violator and the retaliating state, and this information is not available simply because trade negotiations are not carried out in that type of bilateral bargain. ${ }^{12}$

The uncertainty raised by Sebastian is reasonable. Nevertheless, this thesis pursues a different approach. Firstly, it does not agree with the concept that being "effective" means being able to eliminate all underlying problems. Secondly, it does not contend that identifying the purpose of retaliation is like finding a magic wand that would directly solve retaliation problems. Instead it argues that purpose is useful in assessing the degree of effectiveness.

Articles written by Young and Levy, Raustiala and Gerhart are helpful in elucidating this standing point. They note that the most common understanding of effectiveness "solving the underlying problem", presents a severe practical difficulty ${ }^{13}$ because "the factors that may

\footnotetext{
${ }^{10}$ Gerhart, above $\mathrm{n} 7$, at 373 .

${ }^{11}$ Sebastian "The Law of Permissible WTO Retaliation, above ch 2, n 44, at 124-125.

${ }^{12}$ Ibid, at 125 .

${ }^{13}$ Raustiala, above n 7, at 393-394.
} 
influence the solution to a complex international problem are myriad, and in many cases disentangling them is impossible". ${ }^{14}$ Therefore, Raustiala states that many observers define effectiveness in more "modest" terms: as observable, desired changes in behaviour. ${ }^{15}$ Effectiveness can be understood as the degree to which a rule induces desired changes in behaviour that further the goals or purposes of the rule. ${ }^{16}$ This thesis employs this meaning, and therefore, articulating the purpose of retaliation first is important so that effectiveness can be measured objectively.

\section{The Importance in Identifying the Purpose of Retaliation and the Quest to Discover it}

Arbitrators in US - Byrd Amendment observed that the conceptual debate relating to retaliation could have been avoided if the object and purpose of WTO retaliation were identified. ${ }^{17}$ As explained previously, Sebastian argues that even if the object and purpose were identified, they would not drastically simplify the task of arbitrators due to various practical difficulties that will still be encountered by the arbitrators. ${ }^{18}$ This thesis provides that identifying the purpose is not done to solve all problems but to measure and assess the degree of effectiveness objectively. Moreover, because the "effectiveness" and "purpose" have a close relationship, the discussion about the effectiveness in the previous part inevitably also involves the discussion about the purpose.

To recap, why do we need to assess the purpose of retaliation? A rational explanation comes from international relations scholars, particularly those who are studying the compliance issue. They assert that identifying the purpose of a rule or standard is significant and helpful in determining the effectiveness of the rule or standard. ${ }^{19}$ Effectiveness is the degree to which a rule or standard achieves its policy objective. With this in mind, in order to determine the effectiveness of a rule or standard, one should determine first what the purpose or objective of

\footnotetext{
${ }^{14}$ Ibid, at 394; Oran R Young and Marc A Levy "The Effectiveness of International Environmental Regimes" in Oran R Young (ed) The Effectiveness of International Environmental Regimes: Causal Connections and Behavioral Mechanism (MIT Press, 1999) 1 at 4.

${ }^{15}$ Raustiala, above $\mathrm{n} 7$, at 394 .

${ }^{16}$ Ibid, at 388; Gerhart, above n 7, at 363.

${ }^{17}$ US - Byrd Amendment (Article 22.6 - US), above ch 1, n 12, at [6.4].

${ }^{18}$ Sebastian "The Law of Permissible WTO Retaliation", above ch 2, n 44, at 124-125.

${ }^{19}$ Jacobson and Brown-Weiss, above n 6, at 4-5; Gerhart, above n 7, at 373.
} 
that rule or standard is. ${ }^{20}$ States have an underlying purpose when they create and agree on international rules or treaties that will apply to them. As a result, to determine the effectiveness of such rules means to identify whether they achieve the underlying aim or intended purpose of the states. Furthermore, we can get a better picture about the importance of identifying the purpose from an analogy to a speed limit. ${ }^{21}$ Gerhart specifies that one would not know whether, for example, a 65-mile per hour speed limit was effective without knowing what its goal is. The answer would be different if the purpose of introducing this speed limit was to reduce speeding of 70 miles per hour, or for the purpose to reduce accidents or deaths, or to broaden the police's source of revenue. ${ }^{22}$

As an initial conclusion, it is significant to identify or specify first what the purpose(s) WTO retaliation is, and what it intends to achieve before going on to the next question about whether or not WTO retaliation is effective. So, what is the purpose of WTO retaliation? Article 22 of the DSU merely sets forth general principles and procedure that should be followed in order to perform retaliation. Put differently, the DSU does not state explicitly the purpose(s) of retaliation; ${ }^{23}$ and because of that, we need to look for it.

In this thesis, I conduct the search firstly through the interpretation of Article 22 of the DSU in accordance with the customary rules of treaty interpretation. In so doing, I explain first the customary rules of interpretation and their relation to WTO law. Secondly, I look at the reference of the arbitrators to remedies under public international law. Finally, I carry out a search of the purpose of retaliation through academic writings and statements in Article 22.6 arbitration reports.

\footnotetext{
${ }^{20}$ Gerhart, above $\mathrm{n} 7$, at 363 .

${ }^{21}$ Raustiala above n 7, at 395; Gerhart, above n 7, at 363 .

${ }^{22}$ Gerhart, above n 7, at 373.

${ }^{23}$ See US - Byrd Amendment (Article 22.6 - US), above ch 1, n 12, at [6.2].
} 


\section{The First Quest: Interpretation of Article 22 of the DSU}

The drafters of WTO Agreements could not have foreseen all economic and political changes, as well as possible disputes that might arise in the future. As a result, the drafters may have deliberately used broad and ambiguous language in drafting the provisions. The rules of interpretation play a significant role in clarifying ambiguities and filling the gaps in the WTO legal provisions. Article 3.2 of the DSU explicitly states that the existing WTO provisions are to be clarified "in accordance with the customary rules of interpretation of international law." So what are the customary rules of interpretation? And how do we conduct this interpretation? The subsequent part assesses these questions. Following the explanation of the customary rules of interpretation, I conduct the interpretation of Article 22 of the DSU.

\section{A The Customary Rules of Interpretation}

The customary rules of interpretation are mainly codified under Articles 31 and 32 of the Vienna Convention on the Law of Treaties (VCLT), but these two articles do not exhaust the customary rules of interpretation of international law. ${ }^{24}$

Article 31(1) of the VCLT provides that:

A treaty shall be interpreted in good faith in accordance with the ordinary meaning to be given to the terms of the treaty in their context and in the light of its object and purpose.

While Article 31 sets up the primary rules of interpretation, Article 32 provides the supplementary means of interpretation such as the preparatory work of the treaty and the circumstances of treaty conclusion.

\footnotetext{
${ }^{24}$ Andrew D Mitchell Legal Principles in WTO Disputes (Cambridge University Press, 2008) at 76 [Legal Principles in WTO Disputes].
} 
The good faith principle flows from the principle of pacta sunt servanda which provides that every treaty must be performed in good faith. ${ }^{25}$ It also correlates with the principle of "effective treaty interpretation". ${ }^{26}$ The principle of "effective treaty interpretation" entails "the duty...to read all applicable provisions of a treaty in a way that gives meaning to all of them, harmoniously". ${ }^{27}$ Therefore, the good faith principle requires interpreters to read a treaty or its particular sections as a whole and in such a way that would not "result in reducing whole clauses or paragraphs of a treaty to redundancy or inutility". ${ }^{28}$ Moreover, with regard to the good faith principle, the interpretation should not lead to an outcome that is deliberately absurd or unreasonable; therefore, the interpretation should be conducted in a reasonable, honest and fair way. $^{29}$

The WTO panels and the Appellate Body have applied, confirmed and made reference to the principle of good faith. ${ }^{30}$ For instance, the panel in US - Gambling considered good faith to be a "core principle of interpretation of the WTO Agreement". 31

\section{$2 \quad$ Ordinary meaning}

Article 31 of the VCLT requires the interpretation to be carried out in accordance with the ordinary meaning that is given to the terms of the treaty. The ordinary meaning is the normal or true meaning of the terms "taking into account all the consequences which normally and

\footnotetext{
${ }^{25}$ Ibid, at 77; see also the VCLT, art 26.

${ }^{26}$ United States - Measures Affecting the Cross-Border Supply of Gambling and Betting Services WTO DOC WT/DS285/R (2004) at [6.49] (Report of the WTO Panel) [US - Gambling (Panel)].

${ }^{27}$ European Communities - Export Subsidies on Sugar, Complaint by Brazil WTO DOC WT/DS266/R (2004) at [7.152] (Report of the WTO Panel). See also Asif H Qureshi Interpreting WTO Agreement: Problems and Perspectives (Cambridge University Press, 2006) at 13.

${ }^{28}$ Ibid, at [7.151]; Korea - Definitive Safeguard Measure on Imports Certain Dairy Products WTO DOC WT/DS98/AB/R (1999) at [81] (Report of the Appellate Body); United States - Standard for Reformulated and Conventional Gasoline WTO DOC WT/DS2/R (1996) at [12] (Report of the WTO Panel).

${ }^{29}$ US - Gambling (Panel), above n 26, at [6.49]; see also Ian McTaggarat Sinclair Vienna Convention on the Law of Treaties (Manchester University Press, 1984) at 120.

${ }^{30}$ United States - Tax Treatment for "Foreign Sales Corporations" WTO DOC WT/DS108/AB/R (2000) at [101], [footnote 40] (Report of the Appellate Body).

${ }^{31}$ US - Gambling (Panel), above n 26, at [6.10].
} 
reasonably flow from the text., ${ }^{, 32}$ Consequently, it is a textual approach to interpretation. ${ }^{33}$ However, if the parties do not intend such terms to have their ordinary meaning, Article 31(4) of the VCLT provides that special meanings shall be given to the term.

Though an interpretation in accordance with the ordinary meaning can be established in various ways, it has mainly led to the reference of dictionary definitions. ${ }^{34}$ Nonetheless, when having recourse to the dictionary definitions, the context of the term is also significant because the dictionary may provide more than one meaning that may displace or distract the real meaning of a particular term. ${ }^{35}$ The Appellate Body in US-Gambling, for instance, stated that: ${ }^{36}$

...dictionaries, alone, are not necessarily capable of resolving complex questions of interpretation, as they typically aim to catalogue all meanings of words - be those meanings common or rare, universal or specialized.

Therefore, the reference to a dictionary meaning should also have regard to the context, and the object and purpose of a treaty.

\section{The context, and object and purpose}

Article 31(2) of the VCLT states that the context comprises the text, preamble and annexes; and any agreement and instrument made in connection with the conclusion of the treaty; and that certain conditions shall also be taken into account. The context requires the text of the treaty to be read as a whole, and not that paragraphs, articles, sections, chapters or parts be read separately. ${ }^{37}$

Furthermore, Article 31(1) of the VCLT asserts that interpretation should be in accordance with the object and purpose of a treaty. However, to identify the object and purpose

\footnotetext{
${ }^{32}$ Sinclair, above $\mathrm{n} 29$, at 121.

${ }^{33}$ Mitchell Legal Principles in WTO Disputes, above n 24, at 78.

${ }^{34}$ Ibid.

${ }^{35}$ Qureshi, above n 27, at 17.

${ }^{36}$ United States - Measures Affecting the Cross-Border Supply of Gambling and Betting Services WTO DOC WT/DS285/AB/R (2005) at [164] (Report of the Appellate Body) [US - Gambling (AB)].

${ }^{37}$ Sinclair, above $\mathrm{n} 29$, at 127.
} 
is not a simple task. Sinclair argues that "most treaties have no single, undiluted object and purpose but a variety of differing and possibly conflicting objects and purposes." 38 The preamble is often utilised to discern this matter, because it normally stipulates the scope, background, object and purpose of a treaty. Thereby the preamble may contain both the context and the object and purpose of a treaty. The WTO panels and Appellate Body often refer to the preamble of various WTO agreements in the course of their interpretation. ${ }^{39}$

\section{$4 \quad$ Relevant rules of international law}

Article 31(3)(c) of the VCLT provides that "any relevant rules of international law applicable in relations between the parties" shall also be taken into consideration in interpreting a treaty. This means that the interpreters shall also take into account any relevant rules of international law. ${ }^{40}$ Nevertheless, the panel in EC - Biotech Products noted that they are not required to take into account other rules of international law that are not applicable to one of the parties to the dispute. ${ }^{41}$ The WTO panels and Appellate Body, with regard to Article 31(3)(c), have referred to a number of non-WTO rules in interpreting the WTO Agreement. ${ }^{42}$ For instance in US - Shrimp, the Appellate Body, in interpreting the chapeau of Article XX, made a reference to the principle of good faith and the doctrine of abus de droit as general principles of international law. ${ }^{43}$ McLachlan states that a textual analysis of Article 31(3)(c) demonstrates several aspects such as: ${ }^{44}$

\footnotetext{
It refers to 'rules of international law' thus emphasizing that the reference for interpretation purposes must be to rules of law, and not to broader principles or considerations which may not be firmly established as rules.
}

\footnotetext{
38 Ibid, at 130.

${ }^{39}$ Mitchell Legal Principles in WTO Disputes, above n 24, at 81.

${ }^{40}$ The panel in EC - Biotech Products stated that "Article 31(3)(c) mandates a treaty interpreter to take into account other rules of international law", see European Communities - Measuring Affecting the Approval and Marketing of Biotech Products, WTO DOC WT/DS291/R; WT/DS291/R; WT/DS293/R (2006) at [7.49] (Report of the WTO Panel) [EC-Biotech Products (Panel)].

${ }^{41}$ Ibid, at [7.71].

${ }^{42}$ Pauwelyn Conflict of Norms in Public International Law, above ch 1, n 112, at 268.

${ }^{43}$ US - Shrimp (AB), above ch 1, n 3, at [158].

${ }^{44}$ Campbell McLachlan "The Principle of Systemic Integration and Article 31(3)(c) of the Vienna Convention" (2005) 54 Int'1\&Comp L Q 279 at 290.
} 
Mitchell points out that this approach suggests that any principles of customary international law or general principles of law are excluded from Article 31(3)(c) because they are "principles" rather than "rules". ${ }^{45}$ Customary international law is only included to the extent that it encompasses "rules" rather than "principles". 46

The panel in EC - Biotech stated that "rules of international law" seems too broad to include: ${ }^{47}$

...all generally accepted sources of public international law, that is to say, (i) international conventions (treaties), (ii) international custom (customary international law), and (iii) the recognized general principles of law.

However, in the panel's view, treaties and all customary international law are within the "rules of international law". The panel also referred to the Appellate Body decision in US Shrimp that although the recognised general principles of law are less self-evident from the text of Article 31(3)(c), such principles are to be taken into account in the interpretation of WTO provisions. ${ }^{48}$ It seems from this decision that panels and the Appellate Body do not provide a clear distinction between "rules" and "principles". Mitchell attempts to bridge these two approaches by stating that Article 31(3)(c) provides a legal basis for panels and the Appellate Body to interpret WTO provisions in the light of both principles of customary international law and the general principles of law to the extent that such principles are reflected in the "rules of international law". 49

\section{$5 \quad$ Supplementary means of interpretation}

Article 32 of the VCLT states that recourse to supplementary means of interpretation is permitted either "to confirm the meaning resulting from the application of Article 31 " or when the interpretation under Article 31 "leaves the meaning ambiguous or obscure" or "leads to a

\footnotetext{
${ }^{45}$ Mitchell Legal Principles in WTO Disputes, above n 24, at 83.

${ }^{46}$ Ibid.

${ }^{47}$ EC - Biotech Products (Panel), above n 40, at [7.67].

${ }^{48}$ Ibid.

${ }^{49}$ Mitchell Legal Principles in WTO Disputes, above n 24, at 84.
} 
result which is manifestly absurd or unreasonable". Accordingly, recourse to supplementary means of interpretation is not mandatory. ${ }^{50}$ Even though Article 32 stipulates that supplementary means includes the preparatory work of the treaty and the circumstances of its conclusion, it does not define those supplementary materials exhaustively. ${ }^{51}$ In a number of cases, panels and the Appellate Body have utilised several documents from various negotiating rounds to confirm the meaning from the application of Article $31 .{ }^{52}$

\section{A Contracting In: The Customary Rules of Interpretation}

Not only does the DSU recognise the customary rules of interpretation, but also the panels and the Appellate Body often utilise the customary rules of interpretation of international law in interpreting the WTO treaty. Although not all WTO Members are parties to the Vienna Convention, the rules of interpretation still apply for two reasons. Firstly, the rules of interpretation retain the status of customary international law, and secondly, the WTO itself verifies these customary rules of interpretation of international law.

Panels and the Appellate Body in a number of cases have confirmed the customary status of treaty interpretation stipulated in Article 31 and 32 of the VCLT. For instance, the Appellate Body in US - Gasoline provided that Article 31(1) of the VCLT "had attained the status of a rule of customary or general international law".53 The Appellate Body in Japan - Alcoholic Beverages also confirmed that Article 32, supplementary means of interpretation, means the customary rules of international law. ${ }^{54}$

Furthermore, Article 3.2 of the DSU explicitly makes reference to the rules of interpretation, and panels and the Appellate Body have deliberately engaged in how to apply

\footnotetext{
${ }^{50}$ Qureshi, above n 27, at 24.

${ }^{51}$ The Appellate Body in EC - Computer Equipment included the historical background examination with regard to the circumstances of the conclusion of a treaty. See European Communities - Customs Classification of Certain Computer Equipment WTO DOC WT/DS62/AB/R WT/DS67/AB/R WT/DS68/AB/R (1998) at [86] (Report of the Appellate Body) [EC - Computer Equipment (AB)]; Qureshi, above n 27, at 24.

${ }^{52}$ For instance, the Appellate Body in US - Gambling noted recourse to preparatory work as supplementary means of interpretation. See US - Gambling (AB), above n 36, at [236]; Mitchell Legal Principles in WTO Disputes, above n 24 , at 85 .

${ }^{53}$ US - Gasoline (AB), above ch 1, n 120, at [869].

${ }^{54}$ Japan-Alcohol Beverages (AB), above ch 1, n 132, at 10.
} 
these rules of interpretation in the correct way. ${ }^{55}$ For instance, the Appellate Body in India Patents (US) provided that the principles of treaty interpretation "neither require nor condone the imputation into a treaty of words that are not there or the importation into a treaty of concepts that were not intended". ${ }^{56}$ In EC-Chicken Classifications, the panel understood that: ${ }^{57}$

The primary purpose of treaty interpretation is to identify the common intention of the parties and that the rule contained in Article 31 and 32 of the Vienna Convention have been developed to help assessing, in objective terms, what was or what could have been the common intention of the parties to a treaty.

Therefore, interpretation is not about creating new rules but merely about providing meaning to rules of law; consequently, interpretations contra legem are not permitted. ${ }^{58}$

In sum, the rules of treaty interpretation are rules of international law, which panels and the Appellate Body have made reference to in several cases when dealing with WTO treaty interpretation.

\section{B Interpretation of Article 22 of the DSU in Accordance with the Customary Rules of Interpretation}

The panel in Japan - Alcohol stated that the starting point of an interpretation of an international treaty is the wording of the treaty. ${ }^{59}$ The panel explained that the wording should be interpreted in its context and in the light of the object and the purpose of the treaty as a whole; subsequent practice and agreements should be also taken into account. ${ }^{60}$

\footnotetext{
${ }^{55}$ Anja Lindroos and Michael Mehling "Dispelling the Chimera of 'Self-Contained Regimes' International Law and the WTO" (2006) 16(5) EJIL 857 at 868.

${ }^{56}$ India - Patent Protection for Pharmaceuticals and Agricultural Chemical Products WTO DOC WT/DS50/AB/R (1998) at [45] (Report of the Appellate Body).

${ }^{57}$ European Communities - Custom Classification of Frozen Boneless Chicken Cut (Complaint by Thailand) WTO DOC WT/DS286/R (2005) at [7.94] (Report of the WTO Panel).

${ }^{58}$ Joost Pauwelyn "The Role of Public International Law in the WTO" 95 Am J Int'l L (2001) 535 at 554 ["The Role of Public International Law"] at 573.

${ }^{59}$ Japan - Taxes on Alcoholic Beverages WTO DOC WT/DS8/R WT/DS10/R WT/DS11/R (1996) at [6.9] (Report of the WTO Panel).

${ }^{60}$ Ibid.
} 
As stated previously, the text of Article 22 of the DSU does not state expressly the purpose(s) of retaliation. Therefore, it is necessary to interpret the wording of Article 22 in its context and in the light of the objective and the purpose to have an appropriate legal analysis. There are several portions of the wordings of Article 22 that may indicate the purpose of retaliation. They are as follows:

(a) The suspension "shall be temporary" under Articles 22.1 and 22.8 of the DSU

There are two paragraphs under Article 22 of the DSU that state the temporary nature of retaliation. Firstly, paragraph 1 as the general provision provides that both compensation and the suspension of concessions or other obligations are temporary measures. Secondly, paragraph 8 particularly states that the suspension of concessions shall be temporary.

Temporary in nature signals one purpose of retaliation: inducing compliance. The United States in EC - Bananas III (US) (Article 22.6 - EC) stated that the temporary nature indicates that the purpose of retaliation/countermeasures is to induce compliance. The United States' statement was confirmed subsequently by the arbitrators. ${ }^{61}$ Article 22.1 adds another sentence that also specifies the temporary nature of retaliation: neither compensation nor the suspension is preferred to full implementation of a recommendation. ${ }^{62}$ This sentence clearly establishes a connection between the temporary nature of retaliation and pending compliance. ${ }^{63}$ Therefore one purpose that retaliation needs to achieve is inducing compliance.

In short, the temporary nature of suspension of concessions indicates that the DSU has a strong preference for compliance and that retaliation is an alternative measure applied until compliance occurs. ${ }^{64}$

\footnotetext{
${ }^{61}$ EC-Bananas III (US) (Article 22.6 - EC), above ch 1, n 12, at [6.3].

${ }^{62}$ The DSU, art 22.1.

${ }^{63}$ The arbitrators in Canada - Aircraft II (Article 22.6 - Canada) provided that "Article 22.1 of the DSU is particularly clear as to the temporary nature of suspensions of concessions or other obligations, pending compliance." See Canada-Aircraft II (Article 22.6 - Canada), above ch 1, n 13, at [3.105].

${ }^{64}$ Jackson "To Comply or Option to 'Buy-Out”, above ch 1, n 57, at 116.
} 
(b) The level of the suspension "shall be equivalent" to the level of the nullification or impairment under Article 22.4 of the DSU

The arbitrators in EC - Bananas III (US) (Article 22.6 - EC) defined the ordinary meaning of the word "equivalence" as follows: "equal in value, significant or meaning", "having the same effect", "having the same relative position or function", "corresponding to", "something equal in value or worth", also "something tantamount or virtually identical" ${ }^{65}$ The arbitrators also emphasised that the concept of "equivalence" embodied in Article 22.4 of the DSU means that retaliation cannot be imposed in a punitive manner. ${ }^{66}$

Non-punitive or limited sanction seems to be incompatible with the purpose of inducing compliance; because when non-compliance occurs, obviously a tougher sanction is needed in order to have the effect of inducing compliance. The arbitrators in US - Byrd Amendment (Article 22.6 - US) also considered this inconsistency between the purpose of inducing compliance and the equivalent level requirement. They stated that: ${ }^{67}$

By relying on 'inducing compliance' as the benchmark for selection of the most appropriate approach we also run the risk of losing sight of the requirement of Article 22.4 that the level of suspension be equivalent to the level of nullification or impairment.

The wording of equivalent under Article 22.4 indicates retaliation has more a compensatory, rather than punitive, nature. ${ }^{68}$ By merely compensatory in nature, Article 22.4 acknowledges another competing purpose of retaliation that is to restore the balance of concessions resulting from the continuation of a non-compliance measure, or in short, the purpose of rebalancing.

\footnotetext{
${ }^{65}$ EC-Bananas III (US) (Article 22.6-EC), above ch 1, n 12, at [4.1].

${ }^{66} \mathrm{Ibid}$, at [6.3]. See also US - 1916 Act (Article 22.6 - US), above ch 1, n 12, at [5.8].

${ }^{67}$ US - Byrd Amendment (Article 22.6 - US), above ch 1, n 12, at [3.74].

${ }^{68}$ Ibid, at [6.3]. See also Schwartz and Sykes, above ch 1, n 64, at S189.
} 

Agreement

The terms "equivalent" and "appropriate" should not be treated as excessively distinctively. The word "equivalent" refers to the basic character of trade concessions that is reciprocal. Reciprocity is one of the basic principles in the WTO. The word "appropriate" refers to the character of export subsidies and it is also to differentiate prohibited from actionable subsidies. Export subsidies are prohibited regardless of the adverse effects described in Article 5, whereas domestic subsidies require the existence of the adverse effects to be actionable. Moreover, because domestic subsidies are only illegal to the extent they cause those stated adverse effects, the adverse effect should be regarded as the upper limit on countermeasures. ${ }^{69}$ Therefore, the countermeasures should be commensurate with the degree and nature of the adverse effects. ${ }^{70}$ In contrast, prohibited subsidies are illegal regardless of the existence of the adverse effects. In the absence of adverse effects as a ceiling, the countermeasures should be appropriate. What is "appropriate"? Footnotes 9 and 10 of the SCM Agreement only explain that it is "not meant to allow countermeasures that are disproportionate in light of the fact that the subsidies dealt with under these provisions are prohibited."

The SCM Agreement and other WTO provisions say nothing about the proportionality of countermeasures. Nonetheless, the ILC Draft Articles provide the benchmark of proportionality. Article 51 of the ILC Draft Articles states that "[c]ountermeasures must be commensurate with the injury suffered, taking into account the gravity of the internationally wrongful act and its harmful effects on the injured party." The commentary of Article 51 further explains that: ${ }^{71}$

...disproportionate measure may well be judged not to have been necessary to induce the responsible state to comply with its obligations but to have had a punitive aim and to fall outside the purpose of countermeasures enunciated in article 49.

In other words, countermeasures are not proportional if they are aimed to be punitive.

\footnotetext{
${ }^{69}$ Howse and Neven, above ch 1, n 103, at 111.

70 The SCM Agreement, art 7.9.

${ }^{71}$ The ILC Draft Articles, commentary (7) art 51.
} 
Moreover, if we look back at the negotiating history of the $\mathrm{ITO},{ }^{72}$ we can find interpretative notes which explained that the word "appropriate" should be read as providing relief no more than compensation, ${ }^{73}$ and that "the nature of the relief to be granted is compensatory and not punitive."74 Moreover, in the only GATT case regarding suspension, the Working Party, in determining the "appropriate" level of suspension, provided that the level of suspension was determined "having regard to its equivalence to the impairment suffered by the Netherlands as a result of the United States restrictions". ${ }^{75}$

Nonetheless, in explaining the relationship between "appropriate" (Article XXIII) and "substantially equivalent" (Article XIX and XXVIII), the GATT Legal Adviser stated that the wording "appropriate created a wider leeway in calculating retaliatory measures in Article XXIII than in Article XIX or XXVIII. ${ }^{76}$ Moreover, the "substantially equivalent" standard seems less strict than the "equivalent" standard under Article 22.4 of the DSU. ${ }^{77}$

In the light of the above assessment, it appears that the "appropriate" level of countermeasure is more flexible than the "equivalent" standard. The "appropriate" countermeasures might fall within the "equivalent" level or go beyond that. Nonetheless, the "appropriateness" has the upper ceiling that is the non-punitive level.

\footnotetext{
${ }^{72}$ See subsequent part below (interpretation of Article 22 of the DSU).

${ }^{73}$ Sub-Comittee on chapter VIII (Settlemnt of differences-interpretation) Notes of the Seventeenth Meeting E/Conf. 2/C.6/W.102 (16 February 1948).

${ }^{74}$ Havana Conference Reports of the Committee and Principal Sub-Committees UN Doc ICITO1/8 (September 1948) at 155.

${ }^{75}$ US - Suspension of Obligations, above ch 2, n 20, at [2].

${ }^{76}$ GATT Council Minutes of Meeting - Held in the Center William Rappard on 4 May 1988 GATT DOC C/M/220 (8 June 1988) at 35.

${ }^{77}$ Pauwelyn "Calculation and Design of Trade Retaliation", above ch 1, n 60, at 45.
} 
(c) The suspension shall only be applied until the inconsistent measure "has been removed" or the violator member "provides a solution to the nullification" or "a mutually satisfactory solution is reached" under Article 22.8 of the DSU

Article 22.8 provides three situations in which retaliatory measures have to be terminated. They are: the removal of the inconsistent measure, a solution to the nullification or impairment provided, or a mutually satisfactory solution reached. Article 22.8 demonstrates not only when retaliatory measures have to be terminated but also what retaliation can achieve in the end. Put differently, Article 22.8 also reflects the goal that retaliation intends to pursue.

The removal of the inconsistent measure clearly supports the purpose of inducing compliance. Nonetheless, Article 22.8 does not stop its provision with the wording of removal of inconsistent measure, but it provides further other goals that retaliation can achieve that are a solution to the nullification or impairment, or a mutually satisfactory solution. ${ }^{78}$ A mutually agreed solution is one form of settlement provided for in the $\mathrm{DSU},{ }^{79}$ and therefore it is an integral part of the WTO dispute settlement system.

In general, the notion that the wording and the text in Article 22 specifies several purposes that retaliation might serve is also supported by an Article 22.6 arbitration decision. The arbitrators in US - Byrd Amendment (Article 22.6-US) reached a similar conclusion when they questioned whether inducing compliance was the only objective pursued by the DSU. The arbitrators stated that "we are not persuaded that the object purpose of suspension of concessions or other obligations pursuant to Article 22 would be exclusively to induce compliance."

\footnotetext{
${ }^{78}$ For efficiency reason, I consider a solution to the nullification or impairment as a part of mutually satisfactory solution.

${ }^{79}$ The DSU, art 3.7.
} 
According to the customary rules of interpretation, a provision should be interpreted not only in accordance with the wording taken in their context but also in light of the object and purpose of the agreement. The panel in US - Section 301 Trade Act expressed the importance of "text, context, and object and purpose" elements and stated that: ${ }^{80}$

...the elements referred to in Article 31 - text, context and object-and-purpose as well as good faith - are to be viewed as one holistic rule of interpretation rather than a sequence of separate tests to be applied in a hierarchical order.

Therefore, we must interpret the wording of Article 22 not only from the context, but also in the light of the object and purpose of WTO dispute settlement. Article 3.2 of the DSU states that the central objective of the WTO dispute settlement is to provide security and predictability to the multilateral trading system. The Appellate Body in Japan - Alcoholic Beverages II stated the "security and predictability" sought for in the multilateral trading system by the Members will be achieved through the establishment of the dispute settlement system. ${ }^{81}$ Moreover, the panel in US - Section 301 Trade Act noted the importance of the concept of "security and predictability" and provided that: ${ }^{82}$

...the DSU is one of the most important instruments to protect the security and predictability of the multilateral trading system...DSU provisions must, thus, be interpreted in the light of this object and purpose and in a manner which would most effectively enhance it.

In protecting the "security and predictability", firstly the object and purpose of the dispute settlement is to settle disputes through multilateral processes (recourse to and abiding by the rules and procedures of the DSU), and not through unilateral action. ${ }^{83}$ Secondly, the aim of

\footnotetext{
${ }^{80}$ United States - Section 301-310 of the Trade Act of 1974 WTO DOC WT/DS152/R (1999) at [7.22] (Report of the WTO Panel) [US - Section 301 Trade Act (Panel)].

${ }^{81}$ Japan-Alcohol Beverages (AB), above ch $1 \mathrm{n} 132$, at [31].

${ }^{82}$ US - Section 301 Trade Act (Panel), above n 80, at [7.75].

${ }^{83}$ The DSU, art 23.
} 
the dispute settlement mechanism is to secure a positive solution to a dispute (settlement through a mutually acceptable solution). ${ }^{84}$

(a) Security and predictability: settlement of disputes through multilateral procedures and not through unilateral action

Article 23 of the DSU requires all Members to settle disputes through multilateral procedures, and prohibits unilateral enforcement of WTO rights and obligations. In US - Section 301 Trade Act the panel held that Article 23.1 of the DSU prescribes "a general duty of a dual nature. $" 85$ It imposes a duty on all Members to use the multilateral process set out in the DSU when they seek to redress a WTO inconsistency, and because of that, recourse to any other system, in particular a system of unilateral enforcement is excluded. ${ }^{86}$ Prohibition on making unilateral determinations under Article 23.2(a) is often read together with Article 23.1. ${ }^{87}$ Furthermore, the prohibition on taking unilateral action is also applied to the imposition of retaliatory measures. $^{88}$

The suspension of concessions under Article 22 is a bilateral action under the auspices of a multilateral procedure. This means that even though the suspension is a member-to-member retaliation or countermeasure, it cannot be imposed unilaterally. The WTO provides the injured Member with the right to retaliate against the violator Member in the case of nonimplementation, but in doing so, it cannot be imposed in an arbitrary way. Members are prohibited from imposing retaliation without a relevant DSB authorisation. This obligation is stipulated explicitly in Articles 22.6 and 23.2(c), but not in Article 3.7 of the DSU. Nonetheless, in US - Certain EC Products the Appellate Body considered that: ${ }^{89}$

\footnotetext{
${ }^{84}$ Ibid, art 3.7.

${ }^{85}$ US - Section 301 Trade Act (Panel), above n 80, at [7.43].

${ }^{86}$ Ibid.

${ }^{87}$ Ibid at [7.59].

${ }^{88}$ The DSU, art 23.2(c).

${ }^{89}$ United States - Import Measures on Certain Products from the European Communities WTO DOC WT/DS165/AB/R (2000) at [120] (Report of the Appellate Body) [US - Certain EC Products (AB)].
} 
...if a Member has acted in breach of Articles 22.6 and 23.2(c) of the DSU, that Member has also, in view of the nature and content of Article 3.7, last sentence, necessarily acted contrary to the latter provision.

Consequently, regardless of their intended purpose(s) retaliatory measures should not be imposed contrary to the object and purpose of the WTO dispute settlement system to protect "security and predictability" through the multilateral processes. For instance, a state cannot impose retaliation unilaterally even though such retaliatory measures are intended to force the violator state to bring its inconsistent measures into conformity. Put differently, whatever purposes WTO retaliation intends to achieve, such purpose or purposes should not transform retaliation into an arbitrary measure.

(b) Security and predictability: settlement of disputes through a positive solution

Articles 3.2 and 3.7 tell us that the WTO dispute settlement system serves two main functions to protect security and predictability. Firstly is an adjudication function that is "to preserve the rights and obligations of Members under the covered agreements" and "to clarify the existing provisions". Secondly is a settlement function to "secure a positive solution to a dispute".

Interestingly, Article 3.7 states explicitly that "a solution mutually acceptable to the parties to a dispute and consistent with the covered agreements is clearly to be preferred." This means that the main objective of WTO dispute settlement system is not to make rulings; rather the priority is to settle disputes, preferably through a mutually agreed solution. ${ }^{90}$

In US - Shirts and Blouses, the Appellate Body by referring to Article 3.7 clarified that the basic aim of dispute settlement in the WTO is to settle disputes. ${ }^{91}$ The Appellate Body

\footnotetext{
${ }_{90}^{9}$ A Handbook on the WTO Dispute Settlement System, above ch 1, n 4, at 6.

91 United States - Measure Affecting Imports of Woven Wool Shirts and Blouses from India WTO DOC WT/DS33/AB/R (1997) at [19] (Report of the Appellate Body) [US - Shirts and Blouses (AB)].
} 
explained further that the aim is affirmed elsewhere in the DSU, for example Article 3.4 of the DSU. ${ }^{92}$ Article 3.4 of the DSU states that:

Recommendations or rulings made by the DSB shall be aimed at achieving a satisfactory settlement of the matter in accordance with the rights and obligations under this Understanding and under the covered agreements.

There are three points that highlight settlement as the primary aim of dispute settlement. Firstly, the WTO requires consultation as the first stage of any dispute. Secondly, only when the consultation fails to settle the dispute, can parties enter the adjudication stage by requesting the establishment of a panel. Thirdly, bilateral settlement always remains possible or open to the parties at any stage. ${ }^{93}$

Retaliation is part of the WTO dispute settlement system. It is the last resort of remedy provided by the DSU to the Members invoking the dispute settlement procedure. As explained previously, WTO dispute settlement has the function of adjudication and settlement, and the primary purpose is to settle the disputes. This broader purpose of WTO dispute settlement provides retaliation with the possibility to achieve more than one goal. This also explains why Article 22.8 provides three situations in which retaliation should be terminated, because Article 22.8 sustains the two functions (adjudication and settlement) of WTO dispute settlement. The wording of "measure found to be inconsistent with a covered agreement has been removed" maintains the adjudication function whereas "a solution to the nullification" and "a mutually satisfactory solution" support the settlement function.

In the end, there are two main conclusions with regard to the interpretation of the purpose of retaliation in the light of the object and purpose of WTO dispute settlement. Firstly, security and predictability provides a limitation on retaliation so that it might not become an arbitrary measure even in pursuing its purposes. Secondly, in light of the object and purpose of WTO dispute settlement, retaliation can have more than one purpose to pursue.

\footnotetext{
${ }^{92}$ Ibid.

${ }^{93}$ The DSU, arts 3.7 and 11. See also A Handbook on the WTO Dispute Settlement System, above ch 1, n 4, at 6.
} 

supplementary means of interpretation

Supplementary means of interpretation under Article 32 of the VCLT has been employed in fewer WTO cases than Article 31. The panels and Appellate Body in several cases referred to negotiating history, custom classification practice, and working documents of the GATT Secretariat as supplementary means of interpretation. ${ }^{94}$ There is no mandatory requirement to make a reference or resort to supplementary means of interpretation. It is not the intention of this thesis to enter into the debate about the importance of resorting to supplementary means of interpretation. The assessment of the remedies provisions under the ITO Charter and the GATT 1947 aims to confirm the meaning of interpretation of Article 22 of the DSU in accordance with Article 31 of the VCLT (text, context, object and purpose) that have been discussed above.

(a) "Settlement of Differences" provision under the ITO Charter

In the post World War II era, the International Trade Organisation (ITO) was envisioned as the international organisation that regulated and supervised international trade. ${ }^{95}$ The proposal to establish an international trade organisation was initiated by the United States in 1945. Nonetheless, the proposal was considered too ambitious for that time and 5 years later the United States Department announced that the ITO was dead, killed by the US Congress. ${ }^{96}$

The ITO Charter (Havana Charter) provided provisions to resolve disputes. Articles 9297 of the Havana Charter, entitled "Settlement of Differences", governed dispute resolution under the ITO. ${ }^{97}$ The Provisions provide a four-step procedure for dealing with disputes. Firstly, parties to a dispute could resolve that dispute or matter through direct consultation, or if they

${ }^{94}$ United States - Measures Treating Export Restraints as Subsidies WTO DOC WT/DS194/R (2001) at [8.64] (Report of the WTO Panel); EC - Computer Equipment (AB), above n 51, at [92]; Mexico - Measures Affecting Telecommunications Services WTO DOC WT/DS204/R (2004) at [7.44] (Report of the WTO Panel).

95 Amin Alavi Legalization of Development in the WTO between Law and Politics (Wolters Kluwer Law and Business, 2009) at 111.

${ }^{96}$ Palmeter and Mavroidis, above ch $1, \mathrm{n} 18$, at 2.

${ }^{97}$ Terence P Stewart (ed) The GATT Uruguay Round: A Negotiating History (1986-1992) Volume IIb: Commentary (Kluwer Law and Taxation Publishers, 1995) at 2672 [A Negotiating History Commentary]. See also Final Act of the United Nations Conference on Trade and Employment: Havana Charter for an International Trade Organization E/Conf 2/78 (April 1948) [the Havana Charter]. 
wished to do so, they could submit the dispute to arbitration upon terms agreed between them. ${ }^{98}$ If the dispute was not satisfactorily resolved, it could be referred to the Executive Board. ${ }^{99}$ Subsequently, the decision of the Executive Board could be brought before the Conference. The Conference could confirm, modify, or reverse the decision of the Executive Board, and in serious cases, it could release the injured or affected Member(s) on a compensatory basis from obligations or the grant of concessions to any other Member(s). ${ }^{100}$ Finally, the decision of the Conference could be also referred to the International Court of Justice (ICJ) for a review. ${ }^{101}$

During the negotiations of the ITO Charter, the government delegations proposed diverse approaches related to the bringing of disputes before the ICJ. The United States delegations required "the Conference consent" in order to bring a case to the ICJ. ${ }^{102}$ The United States delegations explained the reasons behind the introduction of these words were to avoid a crowded ICJ docket and to maintain the prestige of the ITO. ${ }^{103}$ Meanwhile, the delegates of the Netherlands, Belgium, Cuba and Australia argued that the right of appeal to the ICJ should not be restricted by the Conference's consent. ${ }^{104}$ The Netherlands delegation, for instance, noted that as the representatives of their governments, the decisions of the Conference might be political rather than objective. ${ }^{105}$ The United Kingdom delegation subsequently submitted a memorandum arguing that the Organisation must be expert in its own area and this could not occur if all its disputes were subject to appeal to an outside body. ${ }^{106}$ The United Kingdom delegation raised a concern regarding the danger of the Organisation's affairs being dealt with too legalistically,

\footnotetext{
${ }^{98}$ The Havana Charter, art 93.

${ }^{99}$ Ibid, art 94.

${ }^{100}$ Ibid, art 95.

${ }^{101}$ Ibid, art 96.

102 Suggested Charter for an International Trade Organization of the United Nations (US Department of State Publication 2598, Commercial Policy Series 93, 1946), art 76; Robert E Hudec "The GATT Legal System: A Diplomat's Jurisprudence” (1970) 4 JWTL 615 at 622 [“A Diplomat's Jurisprudence”].

${ }^{103}$ Preparatory Committee of the International Conference on Trade and Employment Verbatim Report of the Tenth Meeting of Committee V - Held in Convocation Hall Church House, Westminster E/PC/T/C.V/PV/10 (8 November 1946) at G.1-G.3.

104 Preparatory Committee of the International Conference on Trade and Employment Verbatim Report of the Eleventh Meeting of Committee V-Held in Hoare Memorial Hall, Church House, Westminster E/PC/T/C.V/PV/11 (9 November 1946) at B.1.

${ }^{105} \mathrm{E} / \mathrm{PC} / \mathrm{T} / \mathrm{C} . \mathrm{V} / \mathrm{PV} / 10$, above $\mathrm{n}$ 103, at G.1-G.2.

${ }^{106}$ Drafting Committee of the Preparatory Committee of the United Nations Conference on Trade and Employment, Article 86 - Summary of Points Made By Mr. Shackle Regarding Interpretation and Settlement of Disputes E/PC/T/C.6/W.77 (14 February 1947) at 1.
} 
arguing that the provisions in the Charter require "the exercise of discretion and economic judgement rather than precise interpretation of the terms of Charter."107

Hudec writes that to solve this consent issue, it was agreed that a legal question could be appealed before the ICJ as a matter of right and such appeals would take the form of a request by the ITO itself to the ICJ for an advisory opinion. ${ }^{108}$ Consequently, the enforcement would still be in the jurisdiction of the ITO. ${ }^{109}$

(b) "Appropriate and compensatory" remedy provision under the ITO Charter

The significant work on the ITO remedy provisions was started in the Second Session of the Preparatory Committee of the United Nations Conference on Trade and Development. ${ }^{110}$ The First Session of the Preparatory Committee was held in London from 15 October to 26 November 1946. Its report was distributed as document E/PC/T/33. The provision concerning the settlement of disputes in the Report of the First Session did not govern any remedy issue. ${ }^{111}$ In the Report of the Second Session, the Preparatory Committee provided the power to authorise the suspension of obligations in addition to the power to give a ruling on the matter to the Conference. ${ }^{112}$

As regards the suspension of obligations, the drafting subcommittee on Chapter VIII dealt with the issue on whether suspension was to serve as a sanction, or compensation for the injury suffered. ${ }^{113}$ While in the subcommittee's ninth meeting, some delegations suggested that both sanction and compensation for nullification or impairment of the benefit be included, ${ }^{114}$ the Report submitted by the Working Party concerning Articles 89 and 90 of the Chapter VIII,

\footnotetext{
${ }^{107}$ Ibid.

${ }^{108}$ Hudec “A Diplomat's Jurisprudence”, above n 102, at 623; the Havana Charter, art 96.

109 Ibid.

${ }^{110}$ Ibid, at 625 .

111 Report of the First Session of the Preparatory Committee of the United Nations Conference on Trade and Employment E/PC/T/33 (November 1946) [London Draft], art 86.

112 Report of the Second Session of the Preparatory Committee of the United Nations Conference on Trade and Employment (adopted by the Preparatory Committee 22 August 1947) E/PC/T/186 (10 September 1947) [1947 Geneva Preparatory Conference Report], art 90.

${ }^{113}$ Hudec "A Diplomat's Jurisprudence", above n 102, at 625.

114 Sub-Committee on chapter VIII (Settlement of differences-interpretation) Notes on the Ninth Meeting E/Conf.2/C.6/W.66 (22 January 1948).
} 
provided the text that recommended "appropriate and compensatory" to the benefit of which has been nullified or impaired. ${ }^{115}$ Interpretative notes of the text proposed by the Working Party explained that "appropriate" should be read to provide a relief no more than compensation. ${ }^{116}$ Subsequently in the Reports of the Havana Conference, the Committee described more clearly the nature of suspension of obligations by stating that "the text provides that the nature of the relief to be granted is compensatory and not punitive."117

In his assessment of the ITO preparatory work, Hudec makes one interesting point that, although the Working Party agreed that the remedy should be "appropriate and compensatory'; these words were not included in the Charter itself. Nevertheless, it only stated "in the form of an ambiguous text plus interpretative note."118 In Hudec's view, the reason behind this drafting decision was to strike a balance between two issues: "a duty to adhere to the rules" and "a duty to pay for damage done" (limitation to the sanction). ${ }^{119}$ Hudec notes that the draftsmen encountered the difficult problem that on the one hand they wanted the ITO legal obligations to be treated and enforced effectively, but on the other hand, they were unwilling to endorse punitive sanction remedies due to the fact that governments would not accept the notion of being punished by an international authority. ${ }^{120}$ Claire Wilcox has a similar point of view to Hudec. Wilcox states that: ${ }^{121}$

Such release [suspension of obligations or concessions] is regarded as a method of restoring a balance of benefits and obligations...it is nowhere described as a penalty to be imposed on members who may violate their obligations or as a sanction to insure that these obligations will be observed.

\footnotetext{
${ }^{115}$ Report of Working Party 3 of Sub-Committee G E/Conf.2/C.6/W.80 (30 January 1948) at 2.

${ }^{116}$ E/Conf. 2/C.6/W.102, above n 73.

${ }^{117}$ UN Doc ICITO1/8, above n 74, at 155.

118 Hudec “A Diplomat's Jurisprudence", above n 102, at 626. Hudec writes that "although the ITO Charter contained a formal 'Annex' for the interpretative notes, it was decided that this bit of clarification belonged in the subcommittee's 'report', a wholly separate document not signed by governments nor even voted on by the plenary drafting body."

${ }^{119}$ Ibid, at 626-627.

${ }^{120}$ Ibid, at 626.

${ }^{121}$ Clair Wilcox A Charter for World Trade (the Macmillan Company, 1949) at 159 (emphasis added).
} 
However, Wilcox also adds that "even though it is not so regarded, it will operate in fact as a sanction and a penalty". 122

\section{(c) Articles XXII and XXIII of the GATT 1947}

The only dispute settlement provisions under GATT 1947 were Articles XXII and XXIII. The limited nature of these procedural rules was due to the fact that it was anticipated that the ITO Charter, which contained detailed dispute settlement rules, would soon apply. ${ }^{123}$ A nullification and impairment provision itself was copied verbatim from the Geneva draft of the ITO Charter. ${ }^{124}$ The ITO was abandoned in 1950 after the United States failed to ratify it; therefore these two provisions have underpinned the GATT dispute settlement system for nearly 50 years. Article XXII.1 simply requires contracting parties to accord sympathetic consideration and afford adequate opportunity for consultation. If the matter is not resolved through consultation under the first paragraph, Article XXII.2 provides that the contracting parties acting together, at the request of a contracting party, consult with other parties concerning the matter.

Moreover, Article XXIII.1 provides pre-retaliation consultation procedures. ${ }^{125}$ If the consultation under Article XXIII.1 fails and the circumstances are serious enough, Article XXIII.2 justifies the contracting parties in authorising the complaining party to suspend the tariff concessions or other GATT obligations.

(d) "Appropriate" remedy provision under the General Agreement

Akin to the ITO Charter, the General Agreement also contains the provisions of remedies. Nonetheless, whereas the ITO Charter provided the Conference with the authority to release the injured Member from obligations to any other Member in the case of the existence of nullification or impairment; ${ }^{126}$ in the GATT, it is the Contracting Parties acting together in

\footnotetext{
122 Ibid.

${ }^{123}$ Palmeter and Mavroidis, above ch 1, n 18, at 7.

${ }^{124}$ Robert E Hudec The GATT Legal System and World Trade Diplomacy (2nd ed, Butterworth Legal Publishers, 1990) at 52 [The GATT Legal System].

${ }^{125}$ Dam, above ch $2, \mathrm{n} 1$, at 353 .

${ }^{126}$ The Havana Charter, art 95.3.
} 
authorising an injured state to suspend the application of such concessions or other obligations to any other contracting party. ${ }^{127}$

Another difference in the remedies provisions in the text of the ITO Charter and the General Agreement is that while the ITO Charter provided such suspension should be "appropriate and compensatory" to the benefit which has been nullified or impaired, the General Agreement only specified the term "appropriate". ${ }^{128}$ Neither the GATT nor the ITO Charter provided the terms "retaliation" or "sanction". ${ }^{29}$ What does "appropriate" mean? Does it go beyond compensatory remedy? There is only one case in the GATT dispute settlement, where the "appropriate" standard was observed, that is the United States dairy quota case. Interestingly the Chairman of the Working Party of the case stated that in his view: ${ }^{130}$

...the test of appropriateness under Article XXIII was the different concept from mere reasonableness, in that account must be taken of the desirability of limiting such action to the best calculated in the circumstances to achieve the objective.

So the word "appropriateness" meant more than just "reasonable". ${ }^{131}$ In the US Suspension of Obligations case, when the Working Party was instructed by contracting parties to investigate the appropriateness of the measure which the Netherlands government proposed to take, it provided that the level of suspension was determined "having regard to its equivalence to the impairment suffered by the Netherlands as a result of the United States restrictions". ${ }^{132}$

From the above assessments we can conclude that, even though in the drafting process several delegations proposed the insertion of punitive sanctions in the text provisions, neither the ITO Charter nor the GATT 1947 provisions provide a punitive punishment for non-compliance. Non-punitive sanctions sustain the character of "settlement of disputes through a positive

\footnotetext{
${ }^{127}$ The GATT 1947, art XXIII.2.

${ }^{128}$ Charnovitz "Rethinking WTO Trade Sanctions", above ch 2, n 17, at 801.

${ }^{129}$ Ibid.

${ }^{130}$ Summary Record of the Seventeenth Meeting held at the Palais des Nations Geneva on Monday 10 October 1952 at 10am GATT DOC SR 7/17 (18 November 1952).

${ }^{131}$ Hudec The GATT Legal System above n 124, at 196.

${ }^{132}$ US - Suspension of Obligations, above ch 2, n 20, at [2].
} 
solution". Put differently, the aim of dispute settlement either in the ITO or the GATT or the WTO is not to punish the violator but to settle the disputes.

\section{Summary}

In the first quest for the purpose of retaliation, I interpreted Article 22 of the DSU in accordance with the customary rules of treaty interpretation. The rules of treaty interpretation require the wording to be interpreted in its context and in the light of the object and the purpose of the treaty as a whole. I emphasised several potions of the wording in Article 22 that may indicate the purpose of retaliation. Firstly, the wording "shall be temporary" in Article 22.1 indicates the purpose of inducing compliance. Secondly, the wording of equivalent under Article 22.4 reflects the purpose of rebalancing. Thirdly, the wording under Article 22.8 demonstrates other purposes that retaliation may achieve: a solution to the nullification or impairment, or a mutually satisfactory solution. I also assessed the term "appropriateness" under the SCM Agreement and argued that both the standard of "equivalence" and "appropriateness" should not be treated excessively distinctive.

Subsequently, I interpreted the wording and the context of Article 22 in the light of the object and the purpose of WTO dispute settlement. Article 3.2 of the DSU highlights "security and predictability" as the central objective of the WTO dispute settlement. In protecting the "security and predictability", the primary object and purpose of WTO dispute settlement is to settle disputes through multilateral process and to secure a positive solution to a dispute. Accordingly, I provided two main conclusions with respect to the interpretation of the purpose of retaliation in the light of the object and purpose of WTO dispute settlement. Firstly, in pursuing its purposes, retaliation should not become an arbitrary measure. Secondly, the objective of WTO dispute settlement offers retaliation the possibility to pursue more than one purpose.

Finally, I examined the remedies provisions under the ITO Charter and the GATT 1947 and concluded that settlement of disputes was the aim of dispute settlement either in the ITO or in the GATT. 


\section{The Second Quest: Reference to Remedies under the ILC Draft Articles on State Responsibility}

The WTO is part of public international law. This means that absolute separation between international law and WTO law is not feasible. The question is to what extent may panels or the Appellate Body apply the rules and principles of public international law? One view is that panels and the Appellate Body can only apply the rules that are expressly stipulated under the covered agreements. ${ }^{133}$ Another view is that states can "contract out" of one or more rules of international law (other than jus cogens), but they cannot contract out of the system of international law. ${ }^{134}$ The answer may lie somewhere in the middle, but it is not the intention of this thesis to solve this debate.

This thesis aims to identify the purposes of WTO retaliation. The arbitrators in Brazil Aircraft referred to the ILC Draft Articles and stated that the purpose of "countermeasures" is, inter alia, to induce compliance. ${ }^{135}$ The question is whether the arbitrators' conclusion regarding the purpose, by referring to the term countermeasure under the ILC Draft Articles, is reasonable. This part provides the assessments of this question. In so doing, firstly, this part elaborates on the remedies under the ILC Draft Articles. Secondly, it looks at the relationship between WTO remedies and remedies under the ILC Draft Articles and whether the arbitrators made the right reference with regard to the purpose of countermeasures.

\section{A Remedies under the ILC Draft Articles}

The basic rules and general principles of international law in the field of state responsibility are codified by the ILC under the ILC Draft Articles. Under the ILC Draft Articles, every internationally wrongful act (action or omission) conducted by a state entails international responsibility. Besides the basic rules and principles, the ILC Draft Articles also regulate the legal consequences of an internationally wrongful act, generally known as remedies

\footnotetext{
133 Joel P Trachtman “The Domain of WTO Dispute Resolution” (1999) 40(2) Harv Int'1 L J 333 at 342 [“The Domain of WTO Dispute Resolution"'].

${ }^{134}$ Ibid.

${ }^{135}$ Brazil-Aircraft (Article 22.6 - Brazil), above ch 1, n 13, at [3.44].
} 
under international law. The subsequent part explains the remedies under the ILC Draft Articles and whether those remedies also exist in WTO law.

\section{$1 \quad$ Cessation and non-repetition}

Article 30 of the ILC Draft Articles provides that the foremost legal consequence of an internationally wrongful act is the cessation of the wrongful act and an assurance and guarantee of non-repetition. This means that the violator state must immediately terminate its illegal act, and that it is prospective in nature. Cessation aims to put an end to the violation of international law and to safeguard the validity and effectiveness of the primary rule. ${ }^{136}$ The arbitration tribunal in Rainbow Warrior noted two conditional requirements for cessation to arise. Firstly, the wrongful act must have a continuing character and, secondly, the obligation breached must still be in force at the time in which the order is issued. ${ }^{137}$ The latter requirement is related to the law of treaties, for instance the legal consequence of the breach is the termination of the treaty because of its material breach. ${ }^{138}$

Cessation also exists in WTO remedies. It is referred to as "the withdrawal" of the inconsistent measure in violation cases. ${ }^{139}$ There is no obligation of withdrawal in cases of nonviolation. The recommendation of withdrawal is only made in cases of violation. In most cases, the withdrawal has a prospective effect. Withdrawal may also apply to the application of the measure or regulation. For instance the Appellate Body in US - Shrimp applied the "applicationoriented chapeau test" and noted that it is the application of the regulation that constitutes arbitrary or unjustifiable discrimination. ${ }^{140}$

Recommendation of non-repetition is not a common practice in WTO dispute settlement, but nothing in the DSU precludes the complainant party from seeking an assurance of non-

\footnotetext{
${ }^{136}$ The ILC Draft Articles, commentary (5) art 30.

137 Rainbow Warrior (New Zealand v France) (1990) 20 RIAA 215 at 113; See also The ILC Draft Articles, commentary (3) art 30.

${ }^{138}$ Sherzod Shadikhodjaev and Nohyoung Park "Cessation and Reparation in the GATT/WTO Legal System: A View from Law of State Responsibility” (2007) 41(6) JWT 1237 at 1240.

${ }^{139}$ The DSU, art 19.1 .

${ }^{140}$ US - Shrimp (AB), above ch 1, n 3, at [115]; see also Cho, above ch 1, n 25, at 774.
} 
repetition. ${ }^{141}$ In Norway - Trondheim, due to the fact that the inconsistent measure had been applied in the past, the panel requested that Norway accepts the illegality of its act and that it provides a guarantee of non-repetition. ${ }^{142}$

\section{Reparation}

The second legal obligation or consequence of an internationally wrongful act is reparation to the injured party. The Permanent Court of International Law (PCIJ) in Chorzów Factory stated that: ${ }^{143}$

...reparation must, as far as possible, wipe out all the consequences of the illegal act and re-establish the situation which would, in all probability, have existed if that act had not been committed.

The ILC Draft Articles provide three forms of reparation: restitution, compensation and satisfaction; they are offered either singly or in combination. ${ }^{144}$

\section{(a) Restitution}

Restitution is the first form of reparation available to the injured state. ${ }^{145}$ The ILC Draft Articles employ a narrow definition of restitution which states that it is intended to re-establish the status quo ante, the situation that existed prior to the occurrence of the wrongful act. ${ }^{146}$ Therefore, restitution is a retroactive form of reparation.

There are very few cases in GATT and WTO dispute settlement where panels have provided the remedy of restitution. ${ }^{147}$ As explained in chapter two, retroactive remedies are not

\footnotetext{
${ }^{141}$ For instance the Philippines in Brazil - Coconut asked about assurance and non-repetition. See Brazil - Measures Affecting Desiccated Coconut WTO DOC WT/DS22/R (1996) at 101 (Report of the WTO Panel).

${ }_{142}$ Mavroidis "Between the Rock and Hard Place", above ch 1, n 90, at 776.

${ }^{143}$ Factory at Chorzów (Germany v Poland) (Indemnity) [1928] PCIJ (Series A No 17) at 47; see also The ILC Draft Articles, commentary (2) art 31.

${ }^{144}$ The ILC Draft Articles, art 34.

${ }^{145}$ Ibid, commentary (1) art 35.

${ }^{146}$ Ibid, commentary (2) art 35.

${ }^{147}$ See Chapter II.
} 
common practice in GATT/WTO dispute settlement. Cho asserts that they are regarded as the exception rather than the rule because both GATT and WTO give priority to the withdrawal of inconsistent measures, which is prospective in nature. ${ }^{148}$

\section{(b) Compensation}

Together with restitution, compensation is one of the main forms of reparation. In the commentary of the ILC Draft Articles, the ILC noted that even though restitution is the primary form of reparation, it is often unavailable or inadequate. Therefore, compensation has a role in filling the gaps and ensuring full reparation for damage suffered. ${ }^{149}$ In other words, compensation is feasible when restitution to the injured party is inadequate. It covers any financially assessable damage including the loss of profit; compensation generally constitutes a pecuniary matter. $^{150}$

The elements of the compensation provisions provided under the DSU are mainly tariff or trade compensation. Nonetheless, this does not mean that WTO dispute settlement precludes the application of financial compensation. US - Copyright Act and US - Cotton are two cases where financial compensation was offered and agreed to. So, although WTO compensation in theory is not a pecuniary matter; in practice, parties to the dispute may agree on some sort of monetary compensation as a temporary settlement.

Moreover, the injured state or complainant cannot directly opt for a compensation remedy; it is non-compliance with the DSB recommendations that gives rise to the option of compensation. In contrast, the law of state responsibility provides that an injured state is entitled to compensation for a wrongful act of state for the damage caused. Furthermore in the case of non-violation complaints, compensation "may be part of a mutually satisfactory adjustment as final settlement of the dispute". ${ }^{151}$ In regard to violation cases, compensation is a temporary remedy. Other important elements of WTO compensation are that it is a "voluntary offer",

\footnotetext{
${ }^{148}$ Cho above ch $1, \mathrm{n} 25$, at 777.

${ }^{149}$ The ILC Draft Articles, commentary (3) art 36.

${ }^{150}$ Ibid, commentary (4) art 36.

${ }^{151}$ The DSU, art 26.1(d).
} 
"mutually acceptable" and "consistent with the covered agreements" including the basic principle of the most favoured nation (MFN). All these elements distinguish WTO compensation from compensation under the law of state responsibility.

\section{(c) Satisfaction}

Satisfaction is usually referred to as the additional form of reparation. This means that satisfaction may be required when the two other forms (restitution and compensation) do not provide full reparation. ${ }^{152}$ Article 37.2 of the ILC Draft Articles states that satisfaction may be in the form of an "acknowledgement of the breach, an expression of regret, a formal of apology, or another appropriate modality". In contrast to compensation, satisfaction is not financially assessable. $^{153}$

Shadikhodjaev points out that in GATT/WTO, satisfaction can come in two forms: assurance of non-repetition and acknowledgement by a violator state. ${ }^{154}$ Satisfaction is not regulated explicitly in the DSU; however, like assurance of non-repetition, nothing prohibits the complainant state from seeking satisfaction and nothing precludes the respondent or violator state from voluntarily acknowledging its violation action and providing satisfaction.

\section{$3 \quad$ Countermeasures}

The ILC Draft Articles explain that the term "countermeasures" is quite similar to the traditional term "reprisals". Both are a self-help response to a breach. However, while the term "reprisals" has been limited to the action taken in the international armed conflict, "countermeasures" cover a type of reprisal outside the context of armed conflict. ${ }^{155}$ The right to countermeasures emerges when the violator state refuses to negotiate and settle the dispute amicably. ${ }^{156}$

\footnotetext{
152 The ILC Draft Articles, commentary (1) art 37.

${ }^{153}$ Ibid, commentary (3) art 37.

${ }^{154}$ Shadikhodjaev, above ch 2, n 7, at 26.

155 The ILC Draft Articles, chapter II countermeasure commentary (3).

${ }^{156}$ Mavroidis "Between a Rock and a Hard Place", above ch 1, n 90, at 772.
} 
Article 51 of the ILC Draft Articles states that the "countermeasures must be commensurate to the injury suffered, taking into account the gravity of the international wrongful act and the rights in question." In short, it must be proportional to the damage suffered and to the gravity of the illegal act. The ILC Draft Articles also provide limitations on the objectives of countermeasures by stating that countermeasures are not intended to be a form of punishment but that it is supposed to induce compliance. ${ }^{157}$

Unlike the DSU, the SCM Agreement adopted the term "countermeasures" for retaliation. Although both of the DSU and the SCM Agreement have terminological differences, the arbitrators noted that the term "countermeasures" in Article 4 of the SCM Agreement may include suspension of concessions or other obligations. ${ }^{158}$ Even though the arbitrators in Canada - Aircraft II (Article 22.6 - Canada) also recognised that "there is no restriction on the types of countermeasure", ${ }^{159}$ the fact is that in practice the form of countermeasures in all Article 4.11 arbitration cases is the suspension of concessions or other obligations. Moreover, while the ILC Draft Articles set up a proportional requirement, Article 4.11 of the SCM Agreement requires appropriateness and the DSU provides an equivalence requirement. By providing such level of limitation, it is obvious that the WTO countermeasures/retaliation is not meant to be punitive.

Countermeasures/retaliation in the WTO is also a self-help instrument; however, it is subject to surveillance and to approval by the DSB. Therefore it is not a unilateral reprisal. The SCM Agreement and the DSU do not state explicitly the objective of a countermeasures/retaliation. The figure placed below provides a general comparison between remedies under public international law and under the WTO.

\footnotetext{
${ }^{157}$ The ILC Draft Articles, commentary (1) art 49.

${ }^{158}$ Brazil-Aircraft (Article 22.6 - Brazil), above ch 1, n 13, at [3.29].

${ }^{159}$ Canada-Aircraft II (Article 22.6 - Canada), above ch 1, n 13, at [footnote 82].
} 
Figure 1 comparison between remedies under public international law and under the WTO

\begin{tabular}{|c|c|}
\hline $\begin{array}{c}\text { Remedies under Public International Law } \\
\text { (the ILC Draft Articles) }\end{array}$ & $\begin{array}{l}\text { Remedies under the WTO } \\
\text { (the DSU/SCM Agreement) }\end{array}$ \\
\hline $\begin{array}{l}\text { 1. Cessation of illegal act } \\
\checkmark \checkmark \text { prospective } \\
\text { 1.1. Assurance of non-repetition }\end{array}$ & $\begin{array}{l}\text { 1. The withdrawal of inconsistent measure } \\
\qquad \checkmark \text { prospective in nature } \\
\text { 1.1 Not common practice but injured state may } \\
\text { seek for the assurance of non-repetition }\end{array}$ \\
\hline $\begin{array}{l}\text { 2. Reparation: } \\
\text { - } \text { Restitution } \\
\checkmark \quad \text { retroactive in nature } \\
\text { - } \text { Compensation } \\
\checkmark \quad \text { feasible when restitution is inadequate } \\
\checkmark \quad \text { generally in monetary form } \\
\text { - Satisfaction } \\
\checkmark \quad \text { additional form of reparation } \\
\checkmark \quad \text { acknowledgement of the breach, an } \\
\quad \text { expression of regret, a formal of apology } \\
\checkmark \quad \text { and so forth } \\
\checkmark \text { not financially assessable }\end{array}$ & $\begin{array}{l}\text { 2. Reparation/restitution remedy is not a } \\
\text { common practice in the WTO. Only a few } \\
\text { numbers of cases where panels } \\
\text { recommended restitution. } \\
\text { - Compensation } \\
\checkmark \quad \text { cannot opt directly for compensation } \\
\checkmark \text { temporary in nature and prospective } \\
\checkmark \text { not a pecuniary concept } \\
\checkmark \text { voluntary offer in terms of additional trade } \\
\text { concessions or market access } \\
\text { Satisfaction } \\
\checkmark \text { not stated explicitly in legal text but } \\
\text { nothing in the DSU precludes the } \\
\text { complainant state from requesting or } \\
\text { seeking a satisfaction remedy } \\
\text { can be in the form of assurance of non- } \\
\text { repetition and acknowledgement by a } \\
\text { violator state }\end{array}$ \\
\hline $\begin{array}{l}\text { 3. Countermeasure } \\
\checkmark \quad \text { emerge when the violator state refuses to } \\
\text { negotiate and settle the dispute amicably } \\
\checkmark \quad \text { proportional to the damage suffered and to } \\
\quad \text { the gravity of the illegal act } \\
\checkmark \quad \text { not intended to be a form of punishment } \\
\checkmark \quad \text { objective is to induce compliance }\end{array}$ & $\begin{array}{l}\text { 3. Countermeasure/Retaliation } \\
\checkmark \quad \text { emerge when non-compliance is taking } \\
\quad \text { place } \\
\checkmark \quad \text { appropriate/equivalent to level of } \\
\quad \text { nullification or impairment } \\
\checkmark \quad \text { non-punitive sanction } \\
\checkmark \quad \text { not stipulated explicitly in the legal text }\end{array}$ \\
\hline
\end{tabular}




\section{B Contracting Out of Remedies under State Responsibility}

To identify whether a WTO remedy is contracting out of remedies under state responsibility, it is significant to determine to what extent the WTO remedies can exclude the application of remedies under state responsibility. Put differently, it must be determined whether WTO remedies are lex specialis in relation to the remedies under state responsibility.

The principle of lex specialis is derived from the latin maxim lex specialis derogate lex generali, which means that a specific rule prevails over a general rule. Article 55 of the ILC Draft Articles elaborates on the principle of lex specialis as follows: ${ }^{160}$

These articles do not apply where and to extent that the conditions for the existence of an internationally wrongful act or to the content or implementation of the international responsibility of a State are governed by special rules of international law.

In other words, the ILC Draft Articles provide that the specific rules of a treaty can modify the content or implementation or effects of the international rules of state responsibility, and that the specific rules will apply to the extent of this modification as provided by the specific rules. Consequently, where specific rules do not modify or deviate, general international law still applies.

Under Article 19.1 of the DSU, a panel or the Appellate Body, in terms of the violation found, shall recommend the violator Member to bring the measure into conformity with the covered agreements. Accordingly, the DSU confirms the general international law of cessation as a WTO remedy. Nonetheless, it does not verify other remedies of general international law. ${ }^{161}$ Compensation and retaliation remedies available under Article 22 of the DSU are different in type and scope from those stipulated in the ILC Draft Articles.

Commentary (3) Article 55 of the ILC Draft Articles concerning lex specialis provides the DSU as a specific example of a rule that has contracted out of general international law in

\footnotetext{
${ }^{160}$ The ILC Draft Articles, art 55.

${ }^{161}$ Pauwelyn Conflict of Norms in Public International Law, above ch 1, n 112, at 219.
} 
terms of remedies (compensation and countermeasures/retaliation). In the footnote, the ILC Draft Articles state that "for WTO purposes, 'compensation' refers to the future conduct, not past conduct, and involves a form of countermeasure." ${ }^{162}$ It also states that the WTO dispute settlement focuses on "cessation rather than reparation". 163

WTO rules are lex specialis in several aspects of general international law on remedies such as the timing, multilateral surveillance and authorisation, nature and permissible level of countermeasures, and three levels of retaliation. ${ }^{164}$ The above assessment, therefore, leads to the conclusion that WTO has contracted out of remedies under general international law.

\section{Reference to the ILC Draft Articles to determine the Purpose of WTO retaliation in Brazil - Aircraft: Sound or Unsound Approach?}

The arbitrators in Brazil - Aircraft (Article 22.6 - Brazil) stated that "the purpose of 'countermeasures' is, inter alia, to induce compliance." ${ }^{65}$ There are two points that we need to consider regarding the arbitrators' statement. Firstly, the arbitrators draw a parallel between the term "countermeasures" used in the SCM Agreement and those employed in the work of ILC on state responsibility. Secondly, they refer to the purpose of countermeasures in Article 47 of the Draft Articles in deciding that the purpose of "countermeasures" under the SCM Agreement is to induce compliance.

However, the arbitrators ignored one important fact in deciding the purpose of countermeasures: WTO law has contracted out of the rules of international law in terms of remedies. By merely making reference to the ILC Draft Articles without further explanation why this is relevant, the arbitrators indirectly applied the concept of something that WTO has contracted out of.

\footnotetext{
${ }^{162}$ The ILC Draft Articles, at footnote 818.

${ }^{163}$ Ibid, at footnote 431

${ }^{164}$ Pauwelyn Conflict of Norms in Public International Law, above ch 1, n 112, at 233; Shadikhodjaev, above ch 2 , n 7, at 45.

${ }^{165}$ Brazil-Aircraft (Article 22.6 - Brazil), above ch 1, n 13, at [3.44].
} 
This is an unsound approach. The arbitrators made the reference to the ILC Draft Articles merely because both the SCM Agreement and the ILC Draft Articles provide the same term "countermeasures" but they did not consider whether both refer to the same concept. Moreover, after making the correlation with regard to the term and purpose, the arbitrators employed an irrelevant benchmark. The arbitrators ignored the benchmark of proportionality provided under public international law, even though they made the reference to, and employed the purpose of, countermeasures under the ILC Draft Articles. The arbitrators decided that "when dealing with a prohibited export subsidy, an amount of countermeasures which corresponds to the total amount of the subsidy is "appropriate'."166 The arbitrators provided that "the total amount of subsidy" benchmark is set at this level in order to cause the countermeasures to have an inducing effect. ${ }^{167}$ In contrast, Article 51 of the ILC Draft Articles provides the "proportionality to the injury suffered" benchmark. ${ }^{168}$ As a result, the arbitrators did not support their finding on the proper benchmark.

So in short, why is this approach unsound? Firstly, the arbitrators referred to the ILC Draft Articles, and indirectly adopted the purpose of countermeasures on the ground that both the SCM Agreement and the ILC Draft Articles have the same term "countermeasures" without considering the fact that WTO has contracted out of the remedies under public international law. Secondly, when they applied the purpose of countermeasures in their decision, they employed a different benchmark from the one provided under public international law. This thesis does not argue that inducing compliance is not the purpose of WTO retaliation. But, it is nonetheless relevant to demonstrate the arbitrators' unsound reference in determining the purpose of inducing compliance.

In conclusion, in the quest or search for the purposes of retaliation, we might make a reference to the purpose of remedies under public international law; however, in doing so we need to have strong reasons to argue that the reference is relevant because the WTO has

\footnotetext{
${ }^{166}$ Ibid, at [3.60].

${ }^{167} \mathrm{Ibid}$, at [3.58]. The arbitrators stated that the equivalent to the level of nullification requirement would limit the efficacy of countermeasures in the case of prohibited subsidies.

${ }^{168}$ Article 51 of the ILC Draft Articles states that "countermeasures must be commensurate with the injury suffered, taking into account the gravity of the internationally wrongful act and its harmful effects on the injured party."
} 
contracted out of general international law on remedies. Thus, the WTO has its own rules, procedures, principles, and purposes with regard to the remedies.

\section{Third Quest: Academic Debates Regarding the Purpose of Retaliation}

The standpoint of this chapter is to search the purpose of retaliation. There are various academic writings arguing about the purpose of retaliation. However, these writings mostly promote a single purpose of retaliation: either inducing compliance or rebalancing. This "single purpose" standpoint has resulted the disagreements and long debates amongst scholars and commentators. For instance, Jackson is the strong proponent of the purpose of inducing compliance, while Sykes and Bello advocate the purpose of rebalancing.

Most commentators and scholars perceive that retaliation serves only single purpose. This part assesses two major schools of thought about WTO retaliation purpose, first, inducing compliance and second, rebalancing.

\section{A The Purpose of Retaliation: Inducing Compliance v Rebalancing}

Article 22 does not explicitly state the purpose of retaliation. Consequently, different views have emerged. For instance, Jackson and Sykes have different opinions as to whether WTO Members are legally obligated to bring their measure into conformity with the recommendations made by WTO panels or the Appellate Body, or whether they have an option to remain in violation and pay "damages". Jackson argues that the DSU text clearly establishes a preference for the obligation to perform, and thus such an opting-out solution is not supported by the text of the DSU. He also disagrees that rebalancing and the efficient breach policy are central to, or even operative in, the normal dispute settlement process. Thus, he strongly disagrees with the view from some commentators that retaliation is intended as a tool to "buy-out" of obligations. $^{169}$

\footnotetext{
${ }^{169}$ Jackson "Obligation to Comply or to Buy Out", above ch 1, n 57, at 115-122.
} 
In contrast, Sykes refers to the WTO as an incomplete contract in economic parlance, because of the difficulties of anticipating all future contingencies and the complexity of relations amidst the Members. Therefore, efficient breach is possible and the damages option facilitates it. Sykes does not dispute that there is a "preference" for compliance implicitly stated in the system, but he argues that "its existence by no means excludes the possibility that Members have the legal right to opt for paying damages". ${ }^{170}$

Below, I classify the academic debate into two main schools of thought and provide the main points of arguments from each camp.

\section{$1 \quad$ Inducing compliance}

Not only have the arbitrators in numerous Article 22.2 arbitral proceedings recognised inducing compliance to be the purpose of WTO retaliation, but many commentators or scholars also support this proposition in their writings. Although the arbitrators in their ruling never explained in detail the reason why they selected inducing compliance, ${ }^{171}$ many commentators or scholars provide the arguments as to why inducing compliance should be the purpose of WTO retaliation. The general arguments presented by the proponents are as follows.

(a) It is in line with the DSU textual context and WTO rules as international law obligations

Jackson is the first scholar who provided an analysis on this matter. In his rebuttal to Bello's argument, he identifies several clauses of the DSU that demonstrate the preference for an obligation to perform the recommendation. ${ }^{172}$ Arguably, amongst others, the legal clauses that are deemed to indicate a strong preference for inducing compliance are: securing the withdrawal

\footnotetext{
${ }^{170}$ Alan O Sykes "The Remedy for Breach of Obligations under the WTO Dispute Settlement Understanding: Damages or Specific Performance?" in Marco Bronckers and Reinhard Quick (eds) New Directions in International Economic Law: Essays in Honour of John H. Jackson (Kluwer Law International, 2000) 347 at 350 ("Damages or Specific Performance?").

${ }^{171}$ The arbitrators referred to the United States' argument that the temporary nature of retaliation demonstrates that the purpose of retaliation is inducing compliance, see EC - Bananas III (US) (Article 22.6), above ch 1, n 12, at [6.3].

${ }^{172}$ Jackson “Misunderstandings of the Nature of Legal Obligations”, above ch 1, n 8, at, 63.
} 
under Article 3.7, bringing the measure into conformity and promptly complying with the recommendation or ruling under Article 19.1, and the temporary nature of compensation or suspension of concession under Article 22.8 of the DSU. ${ }^{173}$ Jackson's arguments are cited and supported subsequently by many scholars. ${ }^{174}$

Furthermore, proponents of a purpose of inducing compliance view WTO rules as binding international legal obligations. Therefore, they believe that when the DSB finds a breach of WTO rules, the Member in question should be deemed to be breaching its obligations under international law, and accordingly, should be required to bring its inconsistent measure into compliance. ${ }^{175}$

(b) The "equivalent" requirement does not mean that retaliation cannot induce compliance

The "equivalent to the level of nullification or impairment" requirement is often considered to be contrary to the purpose of inducing compliance, because the equivalence requirement seems to make the effect of retaliation more compensatory or rebalancing, rather than giving retaliation the effect of inducing compliance. Therefore, rebalancing proponents often employ the "equivalent" requirement as the key counter argument to the "inducing compliance" proponents.

Nevertheless, Spamann argues that due to the method of calculation employed by the arbitrators, there is no "equivalence" or "rebalancing" in the level of suspension and nullification. ${ }^{176}$ By using an economic approach, Spamann notes that the arbitrators were comparing incommensurate values (lost trade and affected trade) in their level of nullification or impairment calculations. ${ }^{177}$ The loss of trade is often less than affected trade; consequently, the

\footnotetext{
173 Ibid.

${ }^{174}$ Cho, above ch 1, n 25, at 770; McGriven, above ch 1, n 49, at 144; Charnovitz "Last Resort against Noncompliance", above ch $1, \mathrm{n} 8$, at 3 .

${ }^{175}$ Jackson "Misunderstandings of the Nature of Legal Obligations", above ch 1, n 8, at 60; Pauwelyn "Enforcement and Countermeasures", above ch 1, n 84, at 341.

${ }^{176}$ Holger Spamann "The Myth of 'Rebalancing' Retaliation in WTO Dispute Settlement Practice" 9(1) JIEL 31.

${ }^{177}$ Ibid, at 45-47.
} 
level of suspension reached by the arbitrators is lower than the level of nullification or impairment suffered by the injured state. ${ }^{178}$

Retaliation itself is already destructive to trade and contrary to the principle of liberalising trade, therefore, a limitation needs to be set on it. This does not mean that the limitation would necessarily undermine the "inducing compliance" purpose. Pauwelyn argues that even though an equivalent suspension does not seem strong enough to induce compliance, this formal remedy is actually backed-up by informal remedies such as the cost to a state's reputation. The formal cost of suspension combined with informal remedies explains the high compliance rate in WTO dispute settlement. ${ }^{179}$

(c) Complainant demanding compliance not rebalancing

For a complainant state, the paramount purpose for entering into dispute settlement is to ensure the withdrawal of the inconsistent measure. This aim can be seen from the strategy of complainant when they impose the sanction of retaliation. Shaffer and Ganin, after assessing the implementation of retaliatory measures in EC - Bananas III, EC - Hormones and US - FSC, conclude that the complainant governments, in imposing retaliatory measures, "selectively targeted politically-significant exporters in the non-complying Member with little or no regard to reciprocal rebalancing in terms of the affected sectors". ${ }^{180}$ Shaffer and Ganin argue that this selective retaliation on highly political sectors or products is obviously aimed at putting maximum pressure on scofflaw governments to comply with rulings. ${ }^{181}$

\footnotetext{
${ }^{178} \mathrm{Ibid}$, at 46.

${ }^{179}$ Pauwelyn "Calculation and Design of Trade Sanction", above ch 1, n 60, at 10-14.

${ }^{180}$ Gregory Shaffer and Daniel Ganin "Extrapolating Purpose from Practice: Rebalancing or Inducing Compliance in Chad P Bown and Joost Pauwelyn (eds) The Law, Economics and Politics of Retaliation in WTO Dispute Settlement (Cambridge University Press, 2010) 73 at 81 ["Extrapolating Purpose from Practice"].

${ }^{181} \mathrm{Ibid}$, at 82 . However, the complainants also tried to select the sectors or products that have minimum impact or harm to complainants' domestic constituencies.
} 


\section{$2 \quad$ Rebalancing}

Bello was the pioneer of this school of thought. She argues that a state is not required to comply with a WTO ruling but instead that the only binding WTO obligation is to maintain a balance of concessions amongst Members. Therefore a Member can choose to comply, or pay compensation, or suffer retaliation in order to balance concessions. ${ }^{182}$

There are two Article 22.6 arbitral proceedings that pointed out the possibility of the existence of other purposes of retaliation. Even though "inducing compliance" proponents strongly oppose this purpose, some well-known scholars such as Sykes, Palmeter, Schwartz and Davey are strong proponents of the "rebalancing" purpose. The general arguments provided by the "rebalancing" proponents are as follows.

(a) No obligation to comply with the ruling

Bello notes that the WTO depends on voluntary compliance, or, in other words, nothing can force a Member to comply with a ruling. Members can deviate from their obligations as long as they are willing to pay compensation or suffer retaliation. "Inducing compliance" proponents obviously disagree with this view. In contrast Sykes, analysing the matter from an economic perspective, supports Bello's point of view and states that her view is analogous to "the duty to perform or to pay damages" from the private contract law theory introduced by Oliver Wendell Holmes. ${ }^{183}$

Moreover, Sykes examines several clauses in the DSU that were argued by Jackson as being "inducing compliance" clauses in a different way. For instance, he points out that the adjective "usually" in Article 3.7 of the DSU implies that "to secure the withdrawal" is not always the objective, so in his view this clause opens up the possibility of the application of other

\footnotetext{
${ }^{182}$ Bello, above ch $1, \mathrm{n} 80$, at 418 .

${ }^{183}$ Sykes "Damages or Specific Performance?", above n 170, at 348; see also Oliver Wendell Holmes "The Path of the Law" (1897) 10 Harv L Rev 457.
} 
objectives. ${ }^{184}$ Overall, Sykes argues that nothing in the DSU states that a Member which chooses compensation or retaliation rather than compliance is in violation of the WTO rules. ${ }^{185}$

(b) Equivalent level requirement favours rebalancing purpose

"Rebalancing" proponents employ the "equivalent level" requirement under Article 22.4 of the DSU as their standing point. The logic for them is that if the aim of retaliation is inducing compliance, the WTO should not have "equivalent to the harm done" as the ceiling level for the suspension. Therefore, Palmeter and Alexandrov state that the purpose of inducing compliance is not consistent with the equivalence requirement. ${ }^{186}$

Moreover, Sykes argues that "equivalent to the harm done" resembles the expectation remedy under private contract law, and by excluding more coercive sanctions, he argues that retaliation serves the duty of paying damages. ${ }^{187}$ Palmeter argues in a similar way, stating that considering the various economies and power sizes of the Members, and the fact that the WTO encourages the Members to make more concessions, the purpose of rebalancing should be deemed to be the purpose of retaliation. ${ }^{188}$

(c) "Rebalancing" purpose is necessary to secure future commitments

"Inducing compliance" proponents strongly criticise the notion that the "rebalancing" purpose allows deviation as long as the violator is willing to pay the damages. However, "rebalancing" proponents argue that this is significant in keeping the system running. Dam states that a system that does not allow any deviation (withdrawal) would tend to discourage the making of concessions in the first place. ${ }^{189}$ This is why, from the perspective of "rebalancing" proponents, the DSU introduced the "equivalent" requirement so that retaliation would not become too coercive or punitive, and threaten the future commitments of the Members. Palmeter

\footnotetext{
${ }^{184}$ Ibid, at 349 .

${ }^{185}$ Ibid, at 349-350.

${ }^{186}$ Palmeter and Alexandrov, above ch 1, n 63, at 651.

${ }^{187}$ Sykes “Damages or Specific Performance?", above n 170, at 351-352.

188 David Palmeter "The WTO Dispute Settlement Mechanism: Compliance with WTO Rulings and other Procedural Problems" Journal of World Intellectual Property 291 at 294 ["Compliance with WTO Rulings"].

${ }^{189}$ Dam, above ch 2, n 1, at 80.
} 
notes that punishing non-compliance severely will risk upsetting the balance that governments have already reached. He recalls Chayes' words: "treaties with teeth are will-o'-the-wisp."190

Sykes also points out that, even though compliance seems preferable, the system has carefully designed a non-compliance option coupled with a sanction similar to expectation damages. ${ }^{191}$ This efficient adjustment will bring a benefit to Members that cannot perform because the cost of performance is too high, by providing them room to restore political balance through compensation or retaliation. ${ }^{192}$

\section{Fourth Quest: Article 22.6 Arbitrators Statements With Regard to the Purpose of Retaliation}

In every Article 22.6 arbitral proceedings, the arbitrators have made statements or references to the purpose of retaliation. Nonetheless, there are gradual changes in their decisions regarding the purpose. For instance, at first in EC - Bananas III (US) (Article 22.6 - EC), the arbitrators stated that inducing compliance is the purpose of WTO suspensions. ${ }^{193}$ Later in US FSC (Article 22.6 - US) and Canada - Aircraft (Article 22.6 - Canada), ${ }^{194}$ the arbitrators provided rulings which amounted to punitive sanctions. Afterwards in US - Byrd Amendment (Article 22.6-US), the arbitrators ruled that the purpose of retaliation is not clear and might be to achieve some form of temporary compensation. ${ }^{195}$ This section examines the purpose stated in the Article 22.6 arbitrators' reports and shows that there are gradual changes in the decisions of the arbitrators with respect to the purpose of retaliation.

\footnotetext{
${ }^{190}$ Palmeter "Compliance with WTO Rulings", above n 188, at 294.

${ }^{191}$ Sykes “Damages or Specific Performance?”, above n 170, at 357. See also Schwartz and Sykes, above ch 1, n 64, at S181.

192 Ibid, at 356-357.

${ }^{193}$ EC-Bananas III (US) (Article 22.6 - EC), above ch 1, n 12, at [6.3].

${ }^{194}$ Canada-Aircraft II (Article 22.6 - Canada), above ch 1, n 13, at [3.121]; US - FSC (Article 22.6 - US) above ch 1, n 13, at [5.52]-[5.57], [6.2].

${ }^{195}$ US - Byrd Amendment (Article 22.6 - US), above ch 1, n 12, at [3.73]-[3.74].
} 


\section{A The Purpose of "Inducing Compliance" with "Equivalent" Level Requirement}

EC - Bananas III (Article 22.6 - EC) was the first WTO Article 22.6 arbitration proceeding on suspension. It was the very first dispute in which the arbitrators made the statement regarding the purpose of retaliation.

The arbitrators in EC - Bananas III (US) (Article 22.6 - EC) confirmed that "the authorization to suspend concessions or other obligations is a temporary measure pending full implementation by the Member concerned." They further agreed with the United States that "this temporary nature indicates that it is the purpose of countermeasures to induce compliance."196 However, in the subsequent statement, the arbitrators set a limitation on the purpose by stating that it (the purpose of inducing compliance) does not mean that the DSB should grant the authorisation to suspend beyond what is equivalent. ${ }^{197}$ The arbitrators held the view that: ${ }^{198}$

...there is nothing in Article 21.1 of the DSU, let alone in paragraphs 4 and 7 of Article 22 , that could be read as a justification for countermeasures of a punitive nature.

The arbitrators in EC - Bananas III (Ecuador) (Article 22.6 - EC) similarly stated that "the object and purpose of Article 22...is to induce compliance". ${ }^{199}$ The purpose of inducing compliance was also confirmed subsequently in EC-Hormones (Article 22.6 - EC) and later in US - Gambling (Article 22.6 - US) and US - Upland Cotton (Article 22.6-US). ${ }^{200}$

There are several interesting points raised in EC - Bananas III (Article 22.6 - EC). Firstly, the statement of the arbitrators regarding the purpose was an assertion; the arbitrators did not provide any further explanation or reference to the text of the WTO agreements. ${ }^{201}$ The

\footnotetext{
${ }^{196}$ EC-Bananas III (US) (Article 22.6-EC), above ch 1, n 12, at [6.3].

${ }^{197}$ Ibid.

${ }^{198}$ Ibid.

${ }^{199}$ EC - Bananas III (Ecuador) (Article 22.6 - EC), above ch 1, n 12, at [76].

${ }^{200}$ EC - Hormones (Article 22.6-EC), above ch 1, n 12, at [39-40]; US - Gambling (Article 22.6 - US), above ch 1, n 12, at [2.7]; US - Upland Cotton (Article 22.6 - US) above ch 1, n 13, at [4.109]-[4.110].

${ }^{201}$ Palmeter and Alexandrov, above ch 1, n 63, at 651.
} 
arbitrators merely stated that they agreed with the United States that the temporary nature indicates that the purpose of countermeasures is to induce compliance. ${ }^{202}$

Secondly, the arbitrators' first statement regarding the purpose and second statement regarding the equivalent level do not support each other. Put differently, the arbitrators set up an ambitious purpose, but that purpose is not supported by or enabled by a similarly ambitious instrument. ${ }^{203}$ The arbitrators put a limitation on the retaliation instrument by stating that suspension cannot go beyond what is equivalent. Consequently, the stated purpose does not fit into the limited instrument, and vice versa, the limited instrument does not support the intended purpose.

\section{B The Purpose of "Inducing Compliance" with "Appropriate" Level Requirement}

The arbitrators provided the standard of "appropriate" countermeasures in the retaliation disputes related to prohibited subsidies under the SCM Agreement. Brazil - Aircraft (Article 22.6 - Brazil) is the first retaliation dispute under the DSU and the SCM Agreement. In this case, the arbitrators concluded that "a countermeasure is 'appropriate' inter alia if it effectively induces compliance." 204 The arbitrators went further by stating that the concept of nullification or impairment is absent from Article 3 and 4 of the SCM Agreement and that an "equivalent" requirement would limit the efficacy of the countermeasures. ${ }^{205}$ Therefore, the arbitrators decided that "an amount of countermeasures which corresponds to the total amount of the subsidy is "appropriate", 206 even though such an amount goes beyond the "equivalent" trade effects caused by the violation.

The arbitrators in US - FSC (Article 22.6 - US) also confirmed that the purpose of countermeasures is to induce compliance. However, the arbitrators adopted a different approach to the arbitrators in Brazil - Aircraft in determining the "appropriateness" and the level of

\footnotetext{
${ }^{202}$ EC-Bananas III (US) (Article 22.6 - EC), above ch 1, n 12, at [6.3].

${ }^{203}$ Pauwelyn "Calculation and Design of Trade Retaliation", above ch 1, n 60, at 50.

${ }^{204}$ Brazil -Aircraft (Article 22.6 - Brazil), above ch 1, n 13, at [3.44].

${ }^{205}$ Ibid, at [3.57]-[3.58].

${ }^{206}$ Ibid, at [3.60].
} 
countermeasures. The arbitrators in $U S-F S C$ went further by taking into consideration the gravity of the breach. The arbitrators considered that: ${ }^{207}$

...in assessing the "appropriateness" of such countermeasures - in light of the gravity of the breach -, a margin of appreciation is to be granted, due to the severity of the breach.

So in carrying out the "appropriateness" test, the arbitrators considered not only the trade effects but also the gravity of the breach (the violation).

In Canada - Aircraft II (Article 22.6 - Canada), the arbitrators recognised the purpose of inducing compliance. Moreover, because of Canada's statement that it did not intend to withdraw its inconsistent measures, the arbitrators considered that it was appropriate to add another 20 per cent of the amount of the subsidy to the total amount of the subsidy to cause Canada to comply. ${ }^{208}$

Interestingly, even though the arbitrators argued that their approach in assessing the "appropriateness" does not make the countermeasures punitive, ${ }^{209}$ we can observe that the arbitrators have provided tougher sanctions in prohibited subsidies disputes than in other disputes, and in Canada - Aircraft II (Article 22.6 - Canada) the additional 20 per cent constitutes, or has the character of, a punitive sanction.

\section{Inducing Compliance is "not the Only Purpose" Pursued by Retaliation}

The arbitrators started to acknowledge that retaliation may have other purposes in US 1916 Act (Article 22.6 - US). ${ }^{210}$ Nonetheless, the arbitrators did not clarify or list these purposes, but confirmed the previous arbitrators' statements that inducing compliance is the key purpose of retaliation. $^{211}$

${ }^{207}$ US - FSC (Article 22.6-US), above ch 1, n 13, at [5.62].

${ }^{208}$ Canada-Aircraft II (Article 22.6 - Canada), above ch 1, n 13, at [3.107], [3.121].

${ }^{209}$ Brazil - Aircraft (Article 22.6 - Brazil), above ch 1, n 13, at [3.55]; US - FSC (Article 22.6 - US), above ch 1, $\mathrm{n}$ 13 , at [5.56].

${ }^{210}$ US - 1916 Act (Article 22.6 - US), above ch 1, n 12, at [5.5].

${ }^{211}$ Ibid, at [5.4], [5.8]. 
It was the arbitrators in US - Byrd Amendment (Article 22.6 - US) that questioned the exclusivity of inducing compliance as the purpose of retaliation. The arbitrators stated that: ${ }^{212}$

Having regard to Article 3.7 and 22.1 and 22.2 of the DSU as part of the context of Article 22.4 and 22.7, we cannot exclude that inducing compliance is part of the objectives behind suspension of concessions or other obligations, but at most it can be only one of a number of purposes in authorizing the suspension of concessions or other obligations. By relying on 'inducing compliance' as the benchmark for the selection of the most appropriate approach we also run the risk of losing sight of the requirement of Article 22.4 that the level of suspension be equivalent to the level of nullification or impairment.

The arbitrators also explained the reason why the DSU does not explicitly state the purpose of retaliation. In their view, it is because "what may induce compliance is likely to vary in each case" $" 213$. The arbitrators argued that "[i]n some cases, even a very high amount of countermeasures may not achieve compliance, whereas in some others a limited amount may."214 The arbitrators noted that there are two implied purposes: firstly, suspension is intended to "induce compliance", and secondly, it is only "a means of obtaining some form of temporary compensation". ${ }^{215}$ So even though the arbitrators in this case were not convinced that inducing compliance is the only purpose of retaliation, in the end the arbitrators left this problem unanswered by merely stating that the purpose of WTO retaliation is "not clear" and that "a large part of the conceptual debate that took place in these proceedings could have been avoided if a clear "object and purpose" were identified."216

To sum up, I provide a figure that describes the gradual changes of the arbitrators' statements with respect to the purpose of retaliation.

\footnotetext{
${ }^{212}$ US - Byrd Amendment (Article 22.6-US), above ch 1, n 12, at [3.74].

${ }^{213}$ Ibid, at [6.2].

${ }^{214}$ Ibid, at [footnote 131].

${ }^{215} \mathrm{Ibid}$, at [6.2]-[6.3].

${ }^{216}$ Ibid, at [6.4].
} 
Figure 2 Article 22.6 arbitrators' statements with regard to the purpose of retaliation

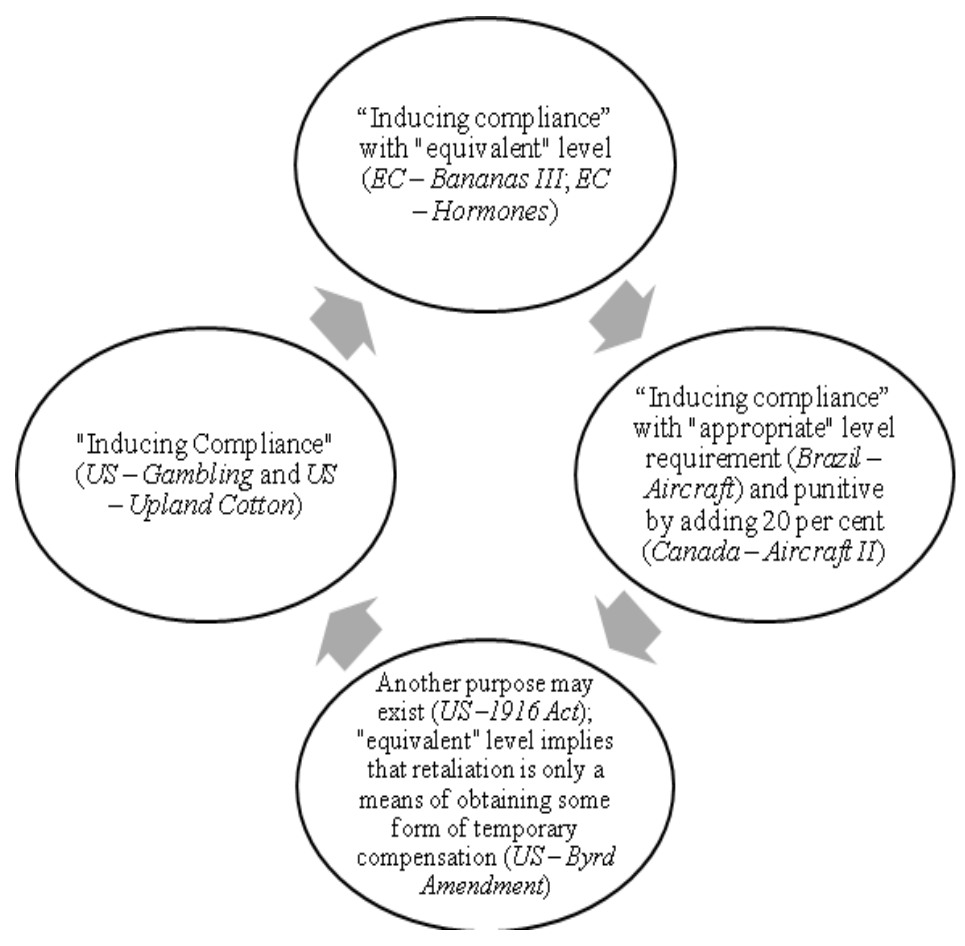

\section{Summary}

The starting point of this chapter was the question of what "effective" means? This thesis adopted the meaning of effectiveness as the degree to which a rule or standard achieves its objective or purpose. This means that to determine the effectiveness of retaliation, it is significant first to identify the purposes of retaliation.

The main aim of this chapter has been to search for the purpose of retaliation. To achieve this, I conducted four main types of analysis. Firstly, I interpreted Article 22 of the DSU in accordance with the general rules of interpretation. This interpretation demonstrated that retaliation can have multiple competing purposes. Secondly, I looked at the reference to the remedies of public international law made by the arbitrators in Brazil - Aircraft. I argued that the arbitrators ignored the fact that WTO law has contracted out of the rules of international law in terms of remedies. By merely referring to the purpose of countermeasures under public international law, only because both the SCM Agreement and the ILC Draft Articles provide the 
same term "countermeasures", without further explanation as to whether or not this is relevant, the arbitrators indirectly applied the concept of something that the WTO has contracted out. Thirdly, I conducted an assessment of competing academic perspectives. This part provided two schools of thought regarding the purpose of retaliation: inducing compliance and rebalancing. Fourthly, I examined Article 22.6 arbitrators' statements concerning the purpose of retaliation. This part demonstrated the gradual changes of the arbitrators' statements regarding the purpose.

To sum up, this chapter's key conclusions are: retaliation can have more than one purpose, the arbitrators in Brazil - Aircraft made unsound reference to the purpose of countermeasures under public international law, inducing compliance and rebalancing are the two most competing purposes of retaliation argued by the commentators, and there are gradual changes in the arbitrators' statements regarding the purpose of retaliation.

Furthermore, although many commentators as well as the arbitrators have stated and argued about the purpose of retaliation, they provide merely the arguments of single purpose: either the purpose of inducing compliance or rebalancing. The interpretation of Article 22 which I undertook in this chapter demonstrates that there are several parts of the wording of Article 22 of the DSU that indicate the purposes of retaliation. Put differently, Article 22 indicates multiple purposes that retaliation can pursue, and they are: inducing compliance, rebalancing and reaching a mutually satisfactory solution. Consequently commentators' debates and disagreements (in advocating one purpose against another purpose of retaliation) are unnecessary. 


\section{CHAPTER FOUR}

\section{THREE LEVELS OF ASSESSMENT TO ARTICULATE THE MULTIPLE PURPOSES OF RETALIATION}

"Although it is understandable why the DSU seems to give primacy to compliance, I believe that we should go in the direction of accepting compensation and suspension of concessions as full alternative to compliance". 1

\section{Overview}

In the previous chapter, I argued that to determine the effectiveness of retaliation, it is important to first identify its purposes. The problem is that the DSU does not state explicitly what the purpose(s) of retaliation is. Therefore, I conducted a search through interpretation, the arbitrators' reference to the remedies of public international law, academic debates and Article 22.6 arbitrators' statements in chapter three. From the previous quest and search, I concluded that WTO retaliation has multiple purposes.

Moreover, I noted in chapter one that the parties determine their goals and how these goals are achieved when they design their contract. I also illustrated the WTO as a "contract organisation". Accordingly, in this chapter I seek to analyse and argue the multiple purposes of retaliation from the design of WTO treaty.

There are three phases of contract design: firstly, the parties define the entitlements or exchanged commitments between them (a bundle of mutual rights and obligations); secondly, the parties define how the entitlements should be protected (protection rules); thirdly, the parties determine the enforcement rules in case of contractual defection. ${ }^{2}$

In this chapter, I establish three levels of assessment to analyse the design or structure of WTO treaty. The first level examines the nature of WTO entitlements, particularly dispute

\footnotetext{
${ }^{1}$ Pieter Jan Kuyper "Remedies and Retaliation in the WTO: Are They Likely to be Effective? The State Perspective and the Company Perspective" (1997) 91 Am Soc'y Int'l L Proc 282 at 284.

${ }^{2}$ Schropp "Trade Policy Flexibility and Enforcement", above ch 1, n 131, at 42-47.
} 
settlement and retaliation entitlements, whether they are owned to the international community as a whole (erga omnes), or owed to the entire membership (erga omnes partes), or owed only reciprocally between Members (bilateral). The second level provides the assessment on how WTO entitlements are protected. The discussion focuses on the transferability of WTO entitlements, for instance whether they can be taken unilaterally as long as compensation is provided or whether they can be transferred only through "re-negotiation". The assessment on this level refers to the protection rules model developed by Calabresi and Melamed. Finally, the third level of assessment provides an elaboration on the enforcement capacity in case of violation.

All of these assessments aim to demonstrate that the WTO treaty is designed in such a way as to support and accommodate the multiple purposes of retaliation.

\section{First Level of Assessment: Identifying the Nature of WTO Dispute Settlement Entitlements}

The WTO is certainly a multilateral agreement, but whether the entitlements are exchanged on a bilateral basis between Members, or are given on a non-reciprocal basis, is different issue. Scholars and commentators have offered different arguments concerning this question. Some of them support the idea that WTO entitlements constitute a set of collective interests, and they are exchanged beyond reciprocal basis. Carmody, for example, by referring to the MFN principle under Article I of the GATT, argues that the WTO is a set of collective obligations owed to all WTO Members. Therefore, WTO obligations are easily understood as obligations erga omnes partes. ${ }^{3}$ There is also an article which supports the notion of indivisible (or erga omnes) obligations applying to the WTO obligations. ${ }^{4}$ Additionally, the arbitrators in $U S-F S C$ ruled that the obligation concerning prohibited subsidies is an erga omnes obligation. ${ }^{5}$

\footnotetext{
${ }^{3}$ Chios Carmody "WTO Obligations as Collective" (2006) 17(2) EJIL 419 at 420-422.

${ }^{4}$ Gazzini "The Legal Nature of WTO Obligations", above ch 1, n 102, at 723-727.

${ }^{5} U S-F S C$ (Article 22.6-US), above ch 1, n 13, at [6.10].
} 
In contrast, there are other commentators who support the notion that WTO entitlements are allocated on a reciprocal or bilateral basis. For example, Pauwelyn asserts that the WTO is a multilateral treaty "of reciprocating type". He argues that MFN is not an obligation of the integral type; rather it is a collection of equivalent bilateral legal relationships in respect of which no discrimination is permitted to take place. ${ }^{6}$ Furthermore, Howse and Neven reject the arbitrators' erga omnes obligation notion. They base their arguments on the fact that the primary stake in a given dispute settlement proceeding belongs only to individual Members. Notwithstanding the fact that there is a community interest in compliance, dispute settlement rulings are binding between parties to disputes and not legally binding on the Members as a whole. ${ }^{7}$

The allocation (reciprocal or non-reciprocal basis) or type of the entitlements correlates to the type of the obligations, or vice versa. If an entitlement is given non-reciprocal and its type is non-transferable, the type of the obligation is absolute. It means that no derogation from the obligation is allowed. To understand the type of WTO obligations first is important because this type (integral or reciprocal) of obligations provides different consequences. If type of WTO obligations is integral or indivisible, then the obligations are absolute and require specific performance. It also means that the entitlements are not transferable; thus, no derogation is allowed. So in case of violation, the primary purpose of retaliation is to induce compliance. In contrast, if the type of WTO obligations is reciprocal in nature, a Member might be allowed to derogate or withdraw from the obligations as long as it provides compensatory adjustment. Therefore, in case of violation, some sorts of alternative settlement can be agreed between parties to dispute. Consequently, inducing compliance would not be the sole purpose that retaliation can pursue.

The concept of obligations erga omnes, erga omnes partes, multilateral and bilateral obligations is developed under the sphere of public international law. It has been observed and discussed in several decisions of the ICJ, the ILC's works, and scholars' writings. Moreover, it is

\footnotetext{
${ }^{6}$ Joost Pauwelyn "A Typology of Multilateral Treaty Obligations: Are WTO Obligations Bilateral or Collective in Nature?" (2003) 14(5) EJIL 907, at 927-928 [“A Typology of Multilateral Treaty Obligations”].

${ }^{7}$ Howse and Neven, above ch 1, n 103, at 118.
} 
generally known that the WTO is part of public international law and that WTO law is not a selfcontained regime. So it is still appropriate and useful to look at the concept erga omnes or erga omnes partes obligations under public international law as a reference in assessing the type of WTO obligations.

\section{A The Concept of Obligations Erga Omnes}

The literal definition of erga omnes is "towards all", "as oppose to all", "against all". However international law scholars argue that the literal definition of erga omnes suffers from a terminology imprecision. This is because the term "omnes" has a double meaning: it can refer either to all collectively or to each other individually. ${ }^{9}$ It is not the intention of this thesis to argue this issue in detail. Nonetheless, the present study examines the concept of obligations erga omnes from the context of International Court of Justice's decisions.

When discussing the concept of obligations erga omnes, one frequently refers to the judgment in the Barcelona Traction case (Second Phase). ${ }^{10}$ The two paragraphs in this judgment explain the concept of obligations erga omnes as follows: firstly, it is the obligations of a State "towards the international community as a whole" and this should be distinguished from "those obligations arising vis-a-vis another State in the field of diplomatic protection”. Secondly, the nature of the obligations is "concern all States". Thirdly, in view of "the importance of the rights" involved, "all States can be held to have a legal interest in their protection". 11 Fourthly, the corresponding rights of protection have entered into the body of general international law and are conferred by international instruments of a "universal or quasi-universal character". 12 The Court also stated that such "obligations [erga omnes] derive from contemporary international law" and from "principles and rules concerning the basic rights of human person". The Court provided examples of the obligations, such as the act of aggression, genocide, slavery, and racial

\footnotetext{
${ }^{8}$ P G W Glare (ed) Oxford Latin Dictionary (Oxford University Press, 1982) at 615-616; 1248-1249 [Oxford Latin Dictionary].

${ }^{9}$ Ibid, ('omnis'). See Christian J Tams Enforcing Obligation Erga Omnes in International Law (Cambridge University Press, 2005) at 101.

${ }^{10}$ Barcelona Traction, Light and Power Company Limited (Belgium v Spain) (Second Phase) [1970] ICJ Rep 1970 at 32 [Barcelona Traction case].

${ }^{11}$ Ibid, at 33 .

${ }^{12} \mathrm{Ibid}$, at 34 .
} 
discrimination. ${ }^{13}$ From these two paragraphs, it is clear that the concept of obligations erga omnes in the Barcelona Traction case confers the "legal interest" of all states (standing) and the "corresponding rights of protection" (countermeasures).

Furthermore, the concept of obligations erga omnes was not outlandish prior to Barcelona Traction Dictum. In the Wimbledon case, the Permanent Court concluded that an artificial waterway connecting two open seas (Suez, Panama, or Kiel Canal) has been "permanently dedicated to the use of the whole world" ${ }^{14}$ The concept of obligations erga omnes also appeared in the Aaland Island dispute. The point of the judgment that related to obligations erga omnes was in respect of the demilitarisation obligation. The Committee of Jurists stated that any state "in possession of the Islands" must conform to the obligation of non-fortification. ${ }^{15}$ Tams and Ragazzi state that such an obligation is related to obligations erga omnes because it was beyond mere consideration of reciprocity and broadened the circle of states bound by the treaty obligation. ${ }^{16}$

The International Court in the 1996 Genocide case provided a new characterisation of obligations erga omnes. The Court noted that the "rights and obligations enshrined by [the Genocide] Convention are rights and obligations erga omnes" and that the "obligation each State thus has to prevent and to punish the crime of genocide is not territorially limited by the Convention". ${ }^{17}$ The concept of erga omnes in the 1996 Genocide case neither points out the legal standing and enforcement like the one in the Barcelona Traction case, nor broadens the circle of states as what confirmed in traditional context (prior to the Barcelona Traction dictum). By being erga omnes, in the 1996 Genocide case sense, an obligation does not have territorial limitation, thus it is directly imposing a high degree of accountability on States. ${ }^{18}$

\footnotetext{
${ }^{13}$ Ibid.

${ }^{14}$ SS “Wimbledon” (UK, France, Italy, Japan v Germany) (Judgment) [1923] PCIJ (Series A No 1) 15 at 28.

${ }^{15}$ Maurizio Ragazzi The Concept of International Obligations Erga Omnes (Oxford University Press, 1997) at 33.

${ }^{16}$ Tams, above n 9, at 105-106; Ragazzi, above n 15, at 33.

${ }^{17}$ Application of the Convention on the Prevention and Punishment of the Crime of Genocide, Preliminary Objection (Bosnia and Herzegovina $v$ Yugoslavia) (Judgment) [1996] ICJ Rep 595 at 616 (emphasis added).

${ }^{18}$ Tams, above $\mathrm{n}$ 9, at 112.
} 


\section{B The Concept of Multilateral and Bilateral Obligations in the Work of the International Law Committee on the Law of Treaties and State Responsibility}

This part briefly reviews the concept of multilateral and bilateral obligations from the work of the ILC on the codification of the law of treaties and state responsibility submitted by the UN special rapporteur.

\section{$1 \quad$ Multilateral or integral type of obligations}

In the Third Report on the Law of Treaties, Gerald Fitzmaurice, the ILC special rapporteur, writes that a treaty of the "integral" type is a treaty "where the force of the obligation is self-existent, absolute and inherent for each party, and not dependent on a corresponding performance by the others." ${ }^{, 19}$ In short, integral obligations are the obligations not only toward particular parties to the treaty but toward the whole world. A clear example of the treaty of an integral type is the 1948 Genocide Convention and Torture Convention.

Another special rapporteur, James Crawford, provides the explanation about the concept of multilateral obligations in the ILC Third Report on state responsibility. Crawford writes that multilateral obligations are obligations owed not individually to a particular State but to a collective, a group of States, or even to the international community as a whole. ${ }^{20} \mathrm{He}$ splits multilateral obligations into: (i) obligations to the international community as a whole (erga omnes), with the consequence that all States in the world have a legal interest in compliance with the obligation. These obligations are virtually coextensive with peremptory obligations (arising under norms of jus cogens); (ii) obligations owed to all the parties to a particular regime (erga omnes partes). He states that this type concerns "obligations which are expressed (or necessarily implied) to relate to matters of the common interest of the parties". Crawford provides examples of such obligations that arise in the fields of the environment (for example, in relation to biodiversity or global warming) and disarmament (for example, a regional nuclear free zone treaty or a test ban treaty). ${ }^{21}$

\footnotetext{
${ }^{19}$ Gerald Fitzmaurice Third Report on the Law of Treaties UN doc. A/CN.4/115 (1958), art 19.

${ }^{20}$ James Crawford Third Report on State Responsibility A/CN.4/507 (2000) at 106.

${ }^{21}$ Ibid.
} 
The ILC Draft Articles also provide the notion of erga omnes and erga omnes partes obligations. By referring to the International Court of Justice (ICJ) ruling in the Barcelona Traction case, the commentary on Article 1 of the ILC Draft Articles states that erga omnes is an obligation towards the international community as a whole. The commentary also differentiates erga omnes obligations from bilateral obligations, which are concerned only with the relations of the responsible State and injured State inter se. Furthermore, the ILC Draft Articles refer to erga omnes partes as an obligation owed to a group and state that the obligation must have been established for the protection of a collective interest. ${ }^{22}$ There are legal consequences that follow from multilateral obligations. Following the breach of multilateral obligations, responsibility can be invoked by any party to the multilateral treaties (erga omnes partes) or by any state (erga omnes). ${ }^{23}$

\section{Bilateral type of obligations}

According to Fitzmaurice, a treaty of the "reciprocating" type is a treaty "providing for a mutual interchange of benefits between the parties, with rights and obligations for each involving specific treatment at the hands of and towards each of the others individually." 24 Furthermore, Crawford distinguishes between bilateral obligations and multilateral obligations. He states that bilateral obligations can arise from various sources, including general international law, bilateral or multilateral treaties or unilateral acts. He also refers to the Vienna Convention on Diplomatic Relations as an example of a multilateral treaty with "bilateral" obligations. ${ }^{25}$

With regard to a breach of bilateral obligations, the ILC Draft Articles provide that the one who is entitled to invoke the responsibility is the individual injured state. ${ }^{26}$ This responsibility, amongst other things, distinguishes bilateral obligations from multilateral obligations.

\footnotetext{
${ }^{22}$ The ILC Draft Articles, commentary of art 48.

${ }^{23}$ Ibid, arts 42 and 48.

${ }^{24}$ Third Report of the Law of Treaties, art 18.

${ }^{25}$ Third Report on State Responsibility, at 99-100.

${ }^{26}$ Ibid, art 42.
} 


\section{Obligations Erga Omnes in Relation to Obligations Erga Omnes Partes}

It is undeniable that one often gets confused between the concept of obligations erga omnes and erga omnes partes. The terms of obligations erga omnes and erga omnes partes, although quite similar terms, indicate independent concepts. ${ }^{27}$ Arangio-Ruiz, UN special rapporteur in the work on codification of state responsibility, first distinguished the concept of obligations erga omnes partes from obligations erga omnes. He writes in his fourth report that: ${ }^{28}$

This legal structure [erga omnes obligations] is typical not only of peremptory norms, but also of other norms of general international law and of a number of multilateral treaty rules [erga omnes partes] obligations.

Subsequently, the ICTY referred to Arangio-Ruiz's remark in its judgment in the Blaskic case. $^{29}$ The ICTY stated that Article 29 of the ICTY statute does not create bilateral relations, in the sense that it imposes an obligation on Members towards all other Members; therefore, it is a valid erga omnes partes obligation. ${ }^{30}$

From here, one can point out that the first difference between these two obligations is the source that gives rise to the obligations. Obligations erga omnes are derived from general international law, whereas obligations erga omnes partes are derived from a multilateral treaty. ${ }^{31}$ It is also noteworthy that international treaties often protect obligations erga omnes under their regimes. $^{32}$

Furthermore, as they are derived from international treaties, obligations erga omnes partes are more numerous and more diverse than obligations erga omnes. ${ }^{33}$ Another important

\footnotetext{
${ }^{27}$ Ragazzi, above n 15, at 203; Tams, above n 9, at 124.

${ }^{28}$ Gaetano Arangio-Ruiz Fourth report on State responsibility A/CN.4/444/Add.1-3 (1992) at 92 (emphasis added).

${ }^{29}$ Appeal Chambers Judgment on the Request of the Republic of Croatia for Review of the Decision of Trial Chamber II of 18 July 1997 (Prosecutor v Tihomir Blaskic) [1997] ICTY Case No IT-95-14-AR at footnote 33 (emphasis added).

${ }^{30}$ Ibid, at 26.

${ }^{31}$ Linos-Alexander Sicilianos "The Classification of Obligations and the Multilateral Dimension of the Relations of International Responsibility" (2002) 13(5) EJIL 1127 at 1136.

32 Ibid.

${ }^{33}$ Tams, above n 9 , at 125 .
} 
difference is the content of both obligations. The obligations obtain or retain their status as erga omnes obligation depending on the importance of specific obligations and/or their non-reciprocal structure; whereas to obtain obligations erga omnes partes, a treaty must recognise a general legal interest or confer a specific right to protection. ${ }^{34}$ In other words, an obligation becomes a valid erga omnes depending on the intrinsic value of the obligation itself. In contrast, the existence of obligations erga omnes partes is granted by the treaty itself. Therefore, as Tams states, the "right to react against treaty breaches exists because the respective treaties say so, not because of some special status of the obligation breached. ${ }^{, 35}$ Several commentators also refer to obligations erga omnes partes as collective obligations. ${ }^{36}$

\section{Obligations Erga Omnes in Relation to Norms of Jus Cogens}

Jus cogens is a peremptory norm of general international law. It is so fundamental and important that Article 53 of the VCLT states that a treaty is void if it conflicts with norms of jus cogens. Article 53 also provides that jus cogens is a norm that is accepted and recognised by the international community as a whole and as a norm from which no derogation is permitted and which can be modified by a subsequent norm having the same character. One might be already aware that erga omnes is an obligation, and jus cogens is a norm, but because of their similarity in character, an overlap between these two concepts is inevitable. In other words, it is difficult to provide a clear-cut distinction between them.

The International Court in the Barcelona Traction case referred to the words "the importance of the rights involved" in order to decide what constitutes a valid erga omnes obligation. ${ }^{37}$ Thus, an obligation obtains the status of erga omnes because it protects important rights (the quality of the rights), not because it is breached in a serious way or because the particular right requires protection. ${ }^{38}$

It has been noted previously that norms of jus cogens protect important or fundamental values, and no state may derogate from them. Because those peremptory norms are so important,

\footnotetext{
${ }^{34}$ Ibid.

35 Ibid.

${ }^{36}$ Pauwelyn "A Typology of Multilateral Treaty Obligations", above n 6; Carmody, above n 3.

${ }^{37}$ Barcelona Traction Case, above n 10, at 33.

${ }^{38}$ Tams, above n 9, at 136-137.
} 
third states also have a legal interest in securing such fundamental norms. Therefore, a treaty that conflicts with a peremptory norm would breach an obligation erga omnes, and this concerns all states (not only parties to the treaty). Third states may request that a treaty conflicting with norms of jus cogens be declared void. ${ }^{39}$ In other words, the existence of a general legal interest in the erga omnes concept is presupposed from jus cogens protection. ${ }^{40}$

To sum up, it can be stated that the norms of jus cogens give rise to obligations erga omnes.

\section{E The WTO Dispute Settlement and Retaliation Obligations: Integral or Reciprocal in Nature}

This part examines the issue of whether WTO dispute settlement and retaliation obligations are erga omnes, erga omnes partes (collective) or bilateral obligations. Firstly, this part elaborates on whether or not WTO obligations in general are obligations erga omnes. Secondly, this part examines the WTO dispute settlement obligations including retaliation obligations in relation to collective or bilateral obligations.

\section{$1 \quad$ WTO obligations are not obligations erga omnes}

With respect to the arbitral panel decision in $U S-F S C$ that prohibited subsidies are obligations erga omnes, it can be argued that the arbitral decision misrepresents the legal framework and the legal concept of obligations erga omnes under public international law. The WTO fundamental obligations, such as market access and liberalisation of trade, are not the type of obligations erga omnes mentioned previously. WTO obligations are not owed to the international community as a whole, and yet they are not absolute obligations, in the sense that

\footnotetext{
${ }^{39}$ The VCLT, art 53; Barcelona Traction case, above n 10. For example, Article 36 of the VCLT provides that a treaty does not create any rights or obligations for a third state without its consent. But when the jus cogens norm is affected, it gives rise to the rights of non-state parties or even all states to request the application of Article 53 of the VCLT to declare that treaty void. See Alexander Orakhelashvili Peremptory Norms in International Law (Oxford University Press, 2006) at 134-135.

${ }^{40}$ Tams, above $\mathrm{n}$ 9, at 149.
} 
states cannot derogate from such obligations. Several reasons why WTO obligations are not obligations erga omnes are as follows:

(a) WTO obligations do not qualify as obligations erga omnes

First and foremost, it is clear that WTO obligations derive from WTO covered agreements, whereas obligations erga omnes derive from general international law. Secondly, the application of WTO obligations and the consequences of the legal act are limited to specific states: the Members of the WTO. Thirdly, WTO obligations are not owed to the international community as a whole; therefore, non-WTO Members do not have any obligations to comply with WTO rules. Fourthly, the WTO allows its Members to modify, re-negotiate or withdraw the concessions. ${ }^{41}$ This is something that is not permitted if the WTO rules are obligations erga omnes.

(b) WTO rules do not fall into the ambit of peremptory norm that give rise to obligations erga omnes

As described previously, an obligation obtains an erga omnes status because it protects important rights, and one practical way to determine the importance of the rights is by evaluating obligations erga omnes in relation to the norms of jus cogens. Therefore, in order to assess whether WTO norms should be valid erga omnes, one significant question that should be answered is whether WTO norms are a part of peremptory norms. The International Court in Nuclear Weapons pointed out that "the question whether a norm is part of jus cogens relates to the legal character of the norm." 42 In addition, Article 53 of the VCLT provides that jus cogens are norms from which no derogation is permitted.

The norms and rules of the WTO do hold a degree of importance. They are necessary and significant as a ground for states to conduct and observe the rules of the game in the international trade sphere. However, they do not obtain peremptory status. States do not have obligations to

\footnotetext{
${ }^{41}$ The GATT 1994, art XXVIII.

${ }^{42}$ Legality of the Threat or Use of Nuclear Weapons International Court of Justice (Advisory Opinion) [1996] ICJ Rep 226 at 83.
} 
the international community as a whole to liberalise their trade. Put differently, WTO law allows its Members to have protectionist measures such as tariff protection, safeguards, anti-dumping and so forth.

2 Various WTO obligations are granted the status of obligations "erga omnes partes"

Since its inception, the WTO has not been merely a body concerning itself with tariff concessions or market access. It has developed its subject matters so that they include nonmarket access concessions and minimum standards obligations. These subject matters do not depend on a reciprocal promise between or amongst Members. For instance every WTO Member has to adjust its regulation to adhere to the minimum standards provided under the TRIPS Agreement. The character of these obligations might resemble obligations erga omnes partes. Several academic writings note the indivisible nature of WTO obligations as the source giving rise to obligations erga omnes partes ${ }^{43}$ nonetheless, this part points out that the erga omnes partes status of various WTO obligations is granted by the covered agreements itself.

Unlike the Human Rights or the Genocide Convention, the WTO treaty does not create, adopt or take up any 'international law obligations that are owed to the international community as a whole' or obligations erga omnes into its provisions. Several obligations such as the minimum standards under TRIPS Agreement or other requirements provided under the SPS, TBT and SCM Agreements are obligations erga omnes partes, as the WTO treaty provides that they are not brought under a bundle of bilateral relations.

A treaty might grant and recognise a general legal interest or specific rights of protection of its members, irrespective of whether the performance of the obligations is owed to all members of the treaty. The status "erga omnes partes" of those obligations is obtained from the WTO treaty itself, not because they are of an indivisible nature or because they protect fundamental values. Therefore, although the WTO treaty recognises the obligation to apply those minimum standards or other requirements to all WTO Members, those obligations do not result

\footnotetext{
${ }^{43}$ Carmody, above n 3, at 420-422; Gazzini "The Legal Nature of WTO Obligations", above ch 1, n 102, at 723-
} 727. 
from peremptory norms or obligations erga omnes. As explained previously, the concept of obligations erga omnes partes is not the same as obligations erga omnes. An obligation becomes a valid erga omnes obligation depending on the intrinsic value of the obligation itself. In contrast, the existence of obligations erga omnes partes is granted by the treaty itself.

\section{$3 \quad$ WTO dispute settlement and retaliation constitute bilateral obligations}

The WTO is a multilateral system. The roles of the DSB in dispute settlement demonstrate this multilateral nature. However, it can be argued that the WTO dispute settlement reflects bilateral obligations. First, the decision of the panel or the Appellate Body or the arbitrators is only binding on the parties to the dispute. Only parties to the dispute can request an appeal, and only the complainant can request an authorisation for suspension of concessions or other obligations. ${ }^{44}$ Second, suspension of concessions under Article 22 of the DSU is a memberto-member retaliation or countermeasure. ${ }^{45}$ Suspension is a trade restriction, thus there is no MFN requirement in imposing this countermeasure. It is merely the right to retaliate imposed by the winning party on the losing party in a non-compliance case. Trachtman provides a similar consideration stating that if the settlement took the form of the complainant imposing barriers against the respondent's goods, Article I does not require that such treatment be accorded to third parties. ${ }^{46}$ Third, the bilateral nature of the WTO dispute settlement can be seen from the settlement between parties to the dispute. The WTO does not require negotiations with third states in connection with bilateral settlement between two parties to the dispute. Nonetheless, third parties or states can bring a complaint against such settlement if it affects their rights to trade.

The bilateral nature of WTO dispute settlement, consequently, provides a possibility to the complainant and respondent to settle the dispute between them through bilateral settlement. This means that the parties may opt for other kinds of settlement as long as they agree on a mutual solution and it does not result in any adverse effects to other parties' trade.

\footnotetext{
${ }^{44}$ Pauwelyn Conflict of Norms in Public International Law, above ch 1, n 112, at 76.

45 Ibid.

${ }^{46}$ Joel P Trachtman "The WTO Cathedral” (2007) 43 Stan J Int'1 L 127 at 149 ["WTO Cathedral”].
} 


\section{Summary}

There are several conclusions that can be drawn from the first level of assessment. Firstly, obligations erga omnes are derived from general international law, and they are obligations not only towards particular parties to the treaty but also towards the whole world (owed to international community as a whole). Put differently, the structure of obligations erga omnes is non-reciprocal. WTO obligations, in contrast, are derived from the WTO Agreements. WTO trade concessions retain a reciprocal character. Moreover, the WTO provides some flexibility under its regime. For instance, a Member may modify or renegotiate its concessions under Article XVIII of the GATT. As a result, we can conclude that WTO obligations do not fall within the ambit of obligations erga omnes under public international law.

Secondly, the WTO has developed its subject matters not only regarding trade concessions or reciprocal market access but also subject matters that do not depend on reciprocal promises amongst Members, such as minimum requirements under the SPS, TBT and TRIPS Agreements. Consequently, some WTO obligations can be categorised as obligations erga omnes partes. Nonetheless, the status of obligations erga omnes partes is granted by the WTO treaty itself, and not because these obligations are indivisible in nature or protecting fundamental values. This is one thing that distinguishes the obligations of erga omnes from those erga omnes partes.

Thirdly, although some WTO rules are erga omnes partes, the WTO dispute settlement and retaliation obligations are bilateral in nature. The bilateral obligations are evident firstly from the fact that the decision of the panel or the Appellate Body or the arbitrators is only binding on the parties to the dispute. Only parties to the dispute can request an appeal, and only the complainant can request an authorisation for suspension of concessions or other obligations. Secondly, a suspension of concessions under Article 22 of the DSU is a member-to-member retaliation or countermeasure. It is merely the right to retaliate imposed by the winning party on the losing party in a non-compliance case. Thirdly, the bilateral nature of the WTO dispute settlement can be seen from the settlement between parties to the dispute. The WTO does not 
require negotiations with third states in connection with bilateral settlement between two parties to the dispute.

The main consequence of this bilateral nature is that even though the WTO has a high preference for compliance (withdrawal of inconsistent measure), its bilateral nature provides parties to the dispute with the possibility of agreeing on other forms of settlement to settle the disagreement between them, for instance through a mutually agreeable solution. Similar to the first phase of contract design, the first level of assessment aims to define the entitlements of the WTO. The conclusion is that the WTO entitlements are not absolute or erga omnes. However, some entitlements are allocated collectively or erga omnes partes, and others, particularly dispute settlement and retaliation are given on a bilateral basis. This discussion is important because if the entitlements are absolute, there is no point to enter the subsequent discussion on the transferability and protection of the entitlements (the second phase of contract design).

\section{Second Level of Assessment: Determining the Protection Rules}

The second level of assessment aims to examine the transferability of WTO entitlements. It is the question of how the WTO entitlements are protected under the WTO Agreement: whether or not the WTO provisions allow Members (entitlements holder) to take or transfer the entitlements, or whether the entitlements can be transferred unilaterally as long as compensation provided, or the entitlements can only be taken by consent of entitlements holder through renegotiation. The applicability of the second level of assessment is also related to the first level of assessment. Put differently, the discussion of the transferability of entitlements would be unnecessary if WTO obligations were obligations erga omnes.

The second level of assessment looks at the flexibility in the WTO treaty (intra-treaty commitments). It also functions as a bridge to the third level (extra-treaty commitments/violations). For instance, if the WTO entitlements can only be taken or transferred by renegotiation, then there is a strict obligation to respect the initial entitlement, which means that Members have a duty to perform. Therefore, there is a stricter sanction in case of violation (extra-treaty commitments). Consequently, the purpose of inducing compliance is the primary 
purpose of retaliation. In contrast, if WTO entitlements can be taken unilaterally as long as compensation is provided, then Members do not have the duty to perform but to compensate in case of violation. Therefore, at the enforcement level, some sorts of compensatory solution are preferable, and thus, inducing compliance is not the sole purpose of retaliation.

This part examines the transferability of WTO entitlements by drawing an analogy to the protection rules model developed by Harvard professors, Calabresi and Melamed, in 1972. ${ }^{47}$ Although Calabresi and Melamed's protection rules model was developed in connection with domestic law, various scholars have made reference to this framework in their discussions in the field of WTO law or international law. ${ }^{48}$ Pauwelyn asserts that one of the main attractions of this model is that it uses "the law and economics criteria of welfare maximization and rational action"; and by making several assumptions, the model can offer useful insights into international law. ${ }^{49}$ Furthermore, Trachtman provides that an economic analysis of law, by focusing on incentives and consequences, is helpful in enhancing understanding of not only contract and tort, but also other areas of law. ${ }^{50}$ He compares the WTO Agreement to a contract, ${ }^{51}$ and Calabresi and Melamed's protection rules model is useful in understanding the incentives provided by remedies for breach of the contract and possible consequences. ${ }^{52}$

In general, Calabresi and Melamed distinguish three types of protection for domestic legal entitlement. The first type is an inalienable rule and is not transferable. The second type is a property rule that the entitlement can be transferred but with the consent of the entitlement's holder. The third type is a liability rule that the entitlement can be taken without consent as long as compensation is provided to the entitlement's holder. The liability rule is often referred to as

\footnotetext{
${ }^{47}$ Guido Calebresi and A Douglas Melamed "Property Rules, Liability Rules, and Inalienability: One View of the Cathedral" (1972) 85 Harv L Rev 1089.

${ }^{48}$ For instance, Schwartz and Sykes, above ch 1, n 64; Trachtman "WTO Cathedral", above n 46; Joost Pauwelyn Optimal Protection of International Law: Navigating between European Absolutism and American Voluntarism (Cambridge University Press, 2008) [Optimal Protection of International Law].

${ }^{49}$ Several assumptions are as follows: the actor is state; the term of welfare maximisation is not limited on monetary term; the preference of states is assumed to be political welfare. See Pauwelyn Optimal Protection of International Law, above n 48, at 27-30.

${ }^{50}$ Trachtman "WTO Cathedral", above n 46, at 145.

${ }^{51}$ It is widely acknowledged that the WTO is an international agreement. See Japan - Alcohol Beverages (AB), above ch 1, n 132.

${ }^{52}$ Trachtman "WTO Cathedral", above n 46, at 145.
} 
the theory of efficient breach. ${ }^{53}$ However, it is important to note that the nomenclature of "efficient breach" in this context is somewhat misleading. The term "breach" suggests the violation or breach of rules (extra-treaty commitments/violation), but there is no breach here because it is permissible under the rule or the contract to deviate from the obligation if you pay compensation (intra-treaty behaviour). Only if the taker fails to pay the compensation will the extra-contractual violation emerge. ${ }^{54}$

The subsequent part provides a more detailed elaboration on the three types of protection rules developed by Calabresi and Melamed.

\section{A Inalienability, Property and Liability Rules}

Calabresi and Melamed's framework suggests in which manner the entitlements are protected and whether the individual is allowed to transfer or trade the entitlements. ${ }^{55}$ The problem of "entitlement", according to Calabresi and Melamed, is "the first issue which must be faced by any legal system". 56 They explain that at a domestic level a state is presented with the conflicting interests of two or more people, or two or more groups of people and have to decide whose interests prevails, whether it grants an entitlement to make noise or an entitlement to have silence, an entitlement to have children or to prohibit them, an entitlement to pollute or to have clean air, and so forth. ${ }^{57}$ Similar to domestic law, international treaties must also allocate the entitlements, for example an entitlement to freely trade or to restrict trade, to tolerate slavery or to respect human rights, and so forth. ${ }^{58}$

After the entitlements are selected, the next question is how to protect those entitlements. Calabresi and Melamed provide three types of entitlements protection: inalienability, property rules, and liability rules.

\footnotetext{
${ }^{53}$ For instance Schwartz and Sykes, above ch 1 n 64, at S180.

${ }^{54}$ Pauwelyn Optimal Protection of International Law, above n 48, at 14.

${ }^{55}$ Calabresi and Melamed, above n 47, at 1092.

${ }^{56} \mathrm{Ibid}$, at 1090 .

57 Ibid.

${ }^{58}$ Pauwelyn Optimal Protection of International Law, above n 48, at 31.
} 
If the initial entitlement is absolute and a taking or transfer of the entitlement is prohibited, inefficient or immoral; such an entitlement is inalienable. Inalienability requires specific performance, where the derogation from the performance is not permitted. In contract parlance, inalienability obliges unconditional specific performance of the contractual rules, no matter what contingencies may occur in the course of contract performance. ${ }^{59}$

Inalienability derives its justification and appropriateness from significant externalities, moralisms and paternalism. ${ }^{60}$ All three are based on economic efficiency, respectively, the impossibility of efficient breach, inappropriateness of monetisation, and the long term benefits of hand-tying. ${ }^{61}$

Significant externalities refer to a very high-cost that no buyer would be willing to pay; for example, avoiding pollution is cheaper than paying its cost. Moralisms, in Calabresi and Melamed's view, are external costs that do not lend themselves to collective measurement which is acceptably objective and non-arbitrary. ${ }^{62}$ For example, if someone is willing to sell him/herself into slavery or sell his/her kidney, one (state) could intervene by valuing the external cost of such an action to the society as high, and thus, stop this action and force the buyer (slave-owner or kidney-owner) to pay that cost. Any monetisation of freedom or a kidney is out of question, because the state decided to make the entitlement of freedom from slavery or prohibition from selling a kidney, inalienable. ${ }^{63}$

The last is paternalism which consists of self-paternalism and true paternalism. Calabresi and Melamed state that self-paternalism explains why Ulysses tied himself to the mast or why individuals pass a bill of rights or constitutional safeguards "so that they will be prevented from

\footnotetext{
59 Simon A B Schropp "Revisiting the 'Compliance -vs.- Rebalancing' Debate in WTO Scholarship: Towards a Unified Research Agenda” (HEI Working Paper No 29, Graduate Institute of International Studies, 2007) at 28 ["Revisiting the 'Compliance -vs.- Rebalancing' Debate"].

${ }^{60}$ Calabresi and Melamed, above n 47, at 1111-1115.

${ }^{61}$ Pauwelyn Optimal Protection of International Law, above n 48, at 35.

${ }^{62}$ Calabresi and Melamed, above n 47, at 1111-1112.

${ }^{63}$ Pauwelyn Optimal Protection of International Law, above n 48, at 35.
} 
yielding to momentary temptations which they deem harmful to themselves" ${ }^{64}$ It is similar to explaining why contracts entered into when drunk or under coercion are invalid. True paternalism refers to prohibitions on a whole range of activities by minors.

\section{Property rules}

The entitlement is protected by a property rule when no one can take the entitlement unless the holder sells it willingly. Under property rules, both parties are under a "specific performance duty", that is a strict obligation to respect the initial entitlement. In this case, the taker has to perform, and a failure to do so is punished so severely that he would never prefer violating the compliance with his obligation. However, a potential taker can buy off the owner's entitlement through renegotiations. He can still avoid his commitments by securing permission from the owner, usually by paying for it. Whenever the parties come to an agreement, the owner cedes their entitlement and sells it to the taker - the transfer is thus bilateral. ${ }^{65}$

\section{$3 \quad$ Liability rules}

The owner of the entitlement that is protected by a mere liability rule cannot object to the action of the transfer of the entitlement, but must accept the payment of damages. In order to operate, liability rules require the availability of a court to determine the value of the damages. ${ }^{66}$ There are three reasons to replace a property rule with a liability rule: (i) hold-outs; (ii) freeloaders or free-riders; and (iii) transaction costs. ${ }^{67}$

Firstly, liability rules resolve a hold-out problem, that is, where the sale of entitlements is efficient (the buyer values the entitlement higher than the seller), certain sellers, or holders of the entitlement, may refuse to sell at their "normal" price in the hope of capturing more of the premium that the buyer is willing to pay. Calabresi and Melamed provide the example where the owners of land may hold-out with the purpose of getting a higher price from the town authority

\footnotetext{
${ }^{64}$ Calabresi and Melamed, above $\mathrm{n}$ 47, at 1113.

${ }^{65}$ Schropp "Revisiting the 'Compliance -vs.- Rebalancing' Debate", above n 59, at 45-47.

${ }^{66}$ Trachtman "WTO Cathedral", above n 46, at 147.

${ }^{67}$ Calabresi and Melamed, above n 47, at 1006-1110.
} 
wanting to build a park. Although the park is Pareto desirable (that is, the town's citizens value a park more than the land-owners value their land), with enough hold-outs, the park will not be built. Under liability rules, the town can simply take the land and compensate its owners at an objectively determined value. ${ }^{6}$

Secondly, liability rules solve the free-rider problem, which occurs on the buyer side. For example, although the town's citizens may each value the land at a price that makes the sale Pareto desirable, some citizens may try to free-ride. That is, they may claim that the park has less value, although the true value is higher. For instance, they claim that the park is only worth $\$ 50$ to them or even nothing at all, when in fact the "true" value of the park is $\$ 100$. They would do so in the hope that other citizens will admit to a higher desire and buy the land with their money, even though, subsequently, everyone would benefit from the park. With enough free-riders unwilling to pay, the park may not materialize, even though it is Pareto desirable. As with the hold-out problem, liability protection may then offer a way out: "if society can value collectively each individual citizen's desire to have a park and charge him a "benefits" tax based upon it, the freeloader problem is gone". In other words, where the entitlement of citizens to their money is protected by liability rules, the town can simply take the citizens' money (that is, impose a tax) and compensate them with the creation of a park. ${ }^{69}$

Thirdly, liability rules can resolve the problem of high transaction costs. A transaction cost is a cost connected with a process of transaction, such as the cost of information gathering, cost of bargaining, post-contractual litigation, enforcement and so forth. Calabresi and Melamed note that: ${ }^{70}$

...perhaps the most common [reason], for employing a liability rule rather than a property rule to protect an entitlement is that market valuation of the entitlement is deemed inefficient, that is, it is either unavailable or too expensive compared to a collective valuation.

\footnotetext{
${ }^{68}$ Ibid, 1106; Pauwelyn Optimal Protection of International Law, above n 48, at 43.

${ }^{69}$ Ibid, at 1107; Ibid, at 45.

${ }^{70} \mathrm{Ibid}$, at 1110 (emphasis added).
} 
Hence, instead of forcing risk-takers to negotiate ex ante a deal with all potential victims (for example accidental injury), in domestic law, the risk-taker can simply take the entitlement (cause an accident) but will have to compensate the victim. ${ }^{71}$

\section{B An Analysis of Protection Rules in WTO Law}

The choice or allocation of entitlement in the first place can have crucial implications for the protection rules in the second place. ${ }^{72}$ For instance where the allocation of entitlements was made on a reciprocal basis (bilateral agreement), a liability rule may be appropriate to protect the entitlements. In contrast, where the entitlements were made on a non-reciprocal basis or allocated with regard to collective interests, a form of inalienability protection may be appropriate. $^{73}$

As a treaty, the WTO should define and assign the primary rules (the entitlements) to each other Member State. The assignment of entitlements in the WTO is based on the concessions exchanged amongst its Members. Due to the fact that most of the rights and obligations under the WTO are related to trade opportunities and interests, it can be remarked that generally the main entitlements of WTO are market access, plus the standards of protection that are stipulated under covered agreements.

The second major question following the allocation of entitlements is about the protection rules of WTO entitlements. How are such entitlements protected? Can they be transferred or taken? If they can be transferred or taken, are they protected under property or liability rules?

Drawing an analogy from the protection rules model, this part seeks to examine whether the WTO allows only specific performance (inalienability rule) or permits a certain degree of flexibility (a property or a liability rule).

\footnotetext{
${ }^{71}$ Pauwelyn Optimal Protection of International Law, above n 48, at 47.

${ }^{72}$ Ibid, at 40.

${ }^{73}$ Ibid, at 41 .
} 
There are two types of international law entitlements that cannot be taken or transferred. First are peremptory norms of general international law or jus cogens, and second are treaties that set out collective obligations (for instances human rights and labour conventions). ${ }^{74}$ The previous chapter of this thesis explained that WTO law is part of international law. Therefore, are there WTO obligations that can be considered inalienable?

With regard to peremptory norms of general international law, as explained previously, none of WTO obligations can be considered as obligations erga omnes and the norms embraced under WTO law are not norms of jus cogens. The Genocide Convention, as a comparison, clearly aims to prevent and punish the crime of genocide. The Convention resembles norms of jus cogens, because conducting genocide, whether committed during war or peace time, is a crime against international law. These norm entitlements cannot be transferred or derogated from, for example by providing financial compensation for those who suffer because of such derogation. Therefore, the provisions embodied are inalienable and absolute. ${ }^{75}$

Violation of a WTO rule, in contrast, does not constitute a "crime" against the whole WTO membership. The WTO also does not provide punitive remedies; instead, it provides equivalent or appropriate ones. Withdrawal or modification of concessions is also permissible under the WTO.

This part also argues that any proposal or view to make WTO entitlements inalienable can risk the future trade commitments in the WTO. Members would think twice about making or offering their commitments if they knew that no withdrawal is allowed or punitive sanction is provided for non-performance. Put differently, the stricter the system is, the more likely Members will be to opt-out of the system. Non-WTO Members would also find the system unattractive and that would negatively affect their desire to join the system.

\footnotetext{
${ }^{74}$ Ibid, at 110 .

75 See Joost Pauwelyn "How Strongly We Protect and Enforce International Law" (Duke Law School Faculty Scholarship Series NELLCO, 2006) at 34-38.
} 
Davey states that international trade law is more concerned with promoting the making of agreements, whereas international law is concerned with assuring commitments made are carried out. Therefore, by making the withdrawal of concession impossible (inalienable), it would discourage the making of the concession in the first place. ${ }^{76}$ By referring to Dam, Davey notes that: ${ }^{77}$

It is better that one hundred commitments should be made and that ten should be withdrawn than that only fifty commitments should be made and that all of them should be kept.

Pauwelyn also suggests that the inalienability of WTO obligations would result in a loss of contractual freedom to address wide diversities and prevent welfare maximisation. ${ }^{78}$ From the above assessment, we can conclude that WTO entitlements are not inalienable.

2 The debate over protection rules of WTO entitlements: property or liability rules

By providing textual analysis of the WTO Charter and the DSU, Jackson argues that WTO law clearly establishes a preference for an obligation to perform the recommendations of the DSB. Compensation shall be resorted to only if the immediate withdrawal of the measure is impracticable. He also adds that several scholars' suggestion that the DSU text gives Members an option to comply with and conform to the ruling or to "buy-out" of its obligations to conform (opting-out solution), is not supported by the text of the DSU. ${ }^{79}$ Jackson's arguments demonstrate that entitlements under WTO law are protected by a property rule. His view is supported by other commentators, such as Nzelibe, ${ }^{80}$ and to some extent, Trachtman. ${ }^{81}$

\footnotetext{
${ }^{76}$ Davey "Compliance Problems", above ch 1, n 16, at 293.

77 Ibid, at 293.

${ }^{78}$ Pauwelyn states that "if welfare maximization is the objective then it may be better to permit countries to contract out of WTO obligations for as long as they do not affect third party rights". See Pauwelyn Optimal Protection of International Law, above n 48, at 125-126.

79 Jackson "Obligation to Comply or to Buy Out", above ch 1, n 57, at 115-116. See Jackson "Misunderstanding on the Nature of Legal Obligation", above ch 1, n 8, at 63.

80 Jibe Nzelibe "The Credibility Imperative: The Political Dynamics of Retaliation in the World Trade Organization's Dispute Resolution Mechanism” 6 (2005) Theo Inq L 215.

81 Trachtman "WTO Cathedral", above n 46.
} 
Trachtman agrees with the legal text analyses provided by Jackson, Nzelibe and others; that is, WTO law is mandatory law and states are not permitted to violate it even if they agree to suffer retaliation. However, he also suggests that it is important to distinguish between the law as legislated and the law in action; accordingly, he states that: ${ }^{82}$

....as a matter of fact and practice, if not as a matter of legal doctrine, the WTO legal system is best characterized as employing a liability rule, rather than a property rule.

Schwartz and Sykes, in contrast, argue that renegotiation and modification of concessions in the WTO are protected by a liability rule. ${ }^{83}$ Article XXVIII:3 of the GATT states that Members may withdraw concessions unilaterally where the MFN compensatory adjustment negotiation fails. Moreover, Article XXI of the GATS provides that WTO Members may renegotiate the schedules by reaching an MFN compensatory adjustment agreement, and in the event that no agreement can be achieved, the WTO Member requesting the change can enact it unilaterally, but subject to a "compensatory adjustment" set by arbitration or the suspension of "substantially equivalent" concessions or benefits by other Members. Other provisions for "escape" in specific areas are the safeguards provisions of Article XIX of GATT and the compulsory licenses provision of Article 31 of the TRIPS Agreement. ${ }^{84}$

Schwartz and Sykes argue that under the MFN principle, trade concessions must extend to all WTO Members, therefore a Member would encounter a holdout problem as well as high transaction costs under a property rule, because it would require negotiations with each WTO Member. ${ }^{85}$ The liability rule approach prevents this problem. Schwartz and Sykes also argue that the rules of the DSU are protected by a liability rule, because the provisions allow violations to continue as long as the violator is willing to pay the price. ${ }^{86}$

\footnotetext{
${ }^{82}$ Ibid, at $146,149$.

${ }^{83}$ Schwartz and Sykes, above ch 1, n 64, at S183-S188.

${ }^{84}$ Trachtman "WTO Cathedral", above n 46, at 148; Pauwelyn Optimal Protection of International Law, above n 48, at 135 .

${ }^{85}$ Schwartz and Sykes, above ch 1, n 64, at S187. See also Trachtman "WTO Cathedral", above n 46, at 149.

${ }^{86}$ Ibid, at S188-S189.
} 

entitlements are protected by a property rule

Various commentators have suggested that international trade agreements are incomplete; in the sense that it does not stipulate all possible contingencies in advance. ${ }^{87}$ This incompleteness is a result of the uncertain conditions that the drafters encountered. ${ }^{88}$ Accordingly, the drafters may be expected to have included provisions that allowed them to adjust the bargain when it becomes mutually disadvantageous. ${ }^{89}$

In the WTO, the provisions for modifying tariff schedules through renegotiation in Article XXVIII of the GATT and for modifying scheduled services commitments in Article XXI of the GATS provide such intra-contractual flexibility. In other words, these provisions offer WTO Members a certain amount of flexibility to adjust the bargain without amounting to a breach of obligation. ${ }^{90}$ For that reason, WTO entitlements under the rules for renegotiation and modification of tariff and services schedules, as well as the rules on safeguards, are protected by a liability rule. Other than these specified rules, all WTO entitlements are protected by a property rule, and such protection is provided under the dispute settlement system. ${ }^{91}$ WTO law provides a high preference for compliance; whereas, compensation and retaliation are intended as temporary measures.

The fact that rules of renegotiation and modification are protected by a liability rule, demonstrates the presence of a certain amount of (intra-contractual) flexibility in the WTO Agreement. Zimmermann describes that such flexibility plays an important role in ensuring that

\footnotetext{
${ }^{87}$ For instance, Henrik Horn, Giovanni Maggi and Robert W Staiger "The GATT/WTO as an Incomplete Contract" (Mimeo, 2006); Lawrence, above ch 1, n 76.

${ }^{88}$ Pauwelyn, for instance, notes that it is difficult or impossible for the drafters to predict and foresee all future economic and political developments both domestically and internationally. See Pauwelyn Optimal Protection of International Law, above n 48, at 137.

${ }^{89}$ Schwartz and Sykes, above ch 1, n 64, at S184.

${ }^{90}$ Claus D Zimmermann "Toleration of Temporary Non-Compliance: The Systemic Safety Valve of WTO Dispute Settlement Revisited" 3(2) (2011) Trade L \& Dev 382, at 384.

${ }^{91}$ Pauwelyn Optimal Protection of International Law, above n 48, at 139.
} 
WTO Members remain to make generous concessions in future rounds, and therefore serving the long-term interest of the international trading system. ${ }^{92}$

As noted above, the WTO entitlements (other than those protected by a liability rule) are protected by a property rule; so theoretically speaking, these entitlements should be backed-up by stricter sanctions at the extra-contractual level. Nonetheless, the suspension of concessions under the DSU and the countermeasures under the SCM Agreement are non-punitive measures. The WTO provides the standard of "equivalence" and "appropriateness" to limit its sanctions. As a result, a paradoxical situation emerges. On the one hand, the DSU specifies high preference for compliance; but on the one hand, the remedies provided under the DSU do not seem strong enough to force the recalcitrant state to comply (the weak back-up enforcement). The third level of assessment aims to examine this issue.

\section{Summary}

The second level of assessment examined the transferability of the WTO entitlements and how these entitlements are protected. It addressed the questions whether or not WTO entitlements can be transferred (inalienability), whether they can be taken unilaterally as long as compensation is provided (liability rules) or whether they only can be only transferred through the consent of the entitlements holder (property rules).

This part has argued that, firstly, WTO entitlements are not inalienable and that withdrawal or modification of concessions is permissible under the WTO. Secondly, WTO entitlements are protected by a property rule. The DSU established a preference for the withdrawal of the inconsistent measure (compliance with the DSB recommendations or rulings). Thirdly, the rules of renegotiation or modification tariff and services schedules as well as the rules on safeguards are protected by a liability rule.

\footnotetext{
${ }^{92}$ Zimmermann, above n 90, at 397-398.
} 
The rules of modifying tariff and services schedules demonstrate an intra-contractual flexibility in WTO Agreement. As noted earlier, the WTO covers various trade interests, areas, and issues, so it is not possible for trade negotiators to predict and foresee all future economic and political developments. This explains why there are provisions in the WTO Agreement (intra-contractual level) that are allowing Members to adjust or to deviate from their obligations. A certain degree of intra-contractual flexibility also plays a significant role to secure future commitments given by WTO Members.

Finally, the first level assessment discerned that WTO obligations are not erga omnes and that dispute settlement and retaliation obligations are bilateral. The second level of assessment provides that WTO entitlements are not inalienable, and WTO entitlements are protected by a property rule, even though there is intra-contractual flexibility offered under the rules of modification tariff and services schedules. This brings us to one paradox that will be assessed in the third level of assessment. On the one hand, the WTO has a high preference for compliance, but on the other hand, it provides a lower level or weak back-up enforcement (non-punitive and equivalent standard suspension).

III

Third Level of Assessment: Back-Up Enforcement Level in Relation to the WTO Preference for Compliance

The first level of assessment gives us an understanding of the fact that parties to the dispute have the possibility of agreeing on other forms of settlement to settle the disagreement between them because of the bilateral nature of dispute settlement and retaliation. Meanwhile, the second level of assessment leaves us with the paradox that WTO entitlements are protected by a property rule (high preference for compliance); nonetheless, the sanction provided under the WTO is non-punitive. The third level of assessment attempts to explain this paradox which in the end leads to the argument that inducing compliance is not the sole purpose of retaliation. 


\section{A High Preference for Compliance and Limitation of Sanction}

The rules of the DSU indicate a strong preference for compliance. Article 3.7 of the DSU states that "the first objective of the dispute settlement mechanism is usually to secure the withdrawal of the measures concerned if these are found to be inconsistent with the provisions of any of the covered agreements." Article 19.1 of the DSU also provides that "where a Panel or the Appellate Body concludes that a measure is inconsistent with a covered agreement, it shall recommend that the Member concerned bring the measure into conformity...". Moreover, Article 21.1 of the DSU stipulates that prompt compliance with the DSB's recommendations and rulings is essential.

The WTO, even though it has a preference for compliance, merely relies on the Members' willingness to comply, and in the case of non-compliance, the DSU provides remedies which are limited in character and nature, such as the equivalence requirement under Article 22.4 of the DSU for suspension of concessions or other obligations. This scheme allows a system of "breach and pay"; therefore, economic analysis of the law argues that the dispute settlement system is designed to encourage efficient breach. ${ }^{93}$ This thesis does not support this notion. The WTO dispute settlement system is not designed to accommodate efficient breach. The DSU clearly states that the central objective of the WTO dispute settlement is to provide security and predictability to the multilateral trading system. Facilitating the theory of efficient breach in WTO dispute settlement would threaten the DSU's stated objective. ${ }^{94}$ Moreover, as pointed out by Collins and Zimmermann, due to the absence of retroactive damages under the DSU and the inexactness of damages calculations, it is very likely that some WTO breaches are not efficient at all. ${ }^{95}$ In the subsequent part, this thesis argues that the rules of the DSU including a system of "breach and pay" are designed to provide members with adequate extra-contractual flexibility.

As noted earlier, WTO entitlements are protected by a property rule. Interestingly, at the enforcement level, the WTO provides remedies that do not seem strong enough to support a property protection. It is reasonable that a high level of protection requires strong back-up

\footnotetext{
${ }^{93}$ See chapter one part III.

${ }^{94}$ David Collins "Efficient Breach, Reliance and Contract Remedies at the WTO" 43 (2009) JWT 225, at 231.

${ }^{95} \mathrm{Ibid}$, at 229-238; Zimmermann, above n 90, at 397-398.
} 
enforcement. Property rules require specific performance and failure to do so is punished severely. Nonetheless, as described in the previous chapter, there is no punitive sanction in the WTO. Consequently, the enforcement provided under WTO law seems somehow insufficient to back-up the entitlements protected by a property rule.

One might claim that in export subsidy cases, the arbitrators have crafted a property rule by calculating the level of suspension of concessions so as to compel compliance. In CanadaAircraft II, the panel added 20 per cent to the amount of the subsidy as a punitive sanction in order to induce compliance. By providing for a punitive sanction, the arbitrators appeared to create a huge distinction between "appropriateness" and "equivalence". Unfortunately, in doing so, the arbitrators did not furnish a strong explanation for their interpretation. ${ }^{96}$ The arbitrators in Canada - Aircraft II (Article 22.6 - Canada), by taking into account the arbitrators' reasoning in US - FSC (Article 22.6 - US), preferred the term "proportional" to "equivalence" in order to explain "appropriateness". What proportional means, in the arbitrators' view, is that it is likely to induce compliance. ${ }^{97}$ Therefore, the arbitrators decided to adjust the level of countermeasures calculated on the basis of the total amount of the subsidy by an amount of 20 per cent in Canada - Aircraft II. ${ }^{98}$

Nonetheless, the arbitrators' interpretation of appropriateness and level of nullification seems to clash with their reference to the ILC Draft Articles and to some cases in international law. ${ }^{99}$ Article 51 of the ILC Draft Articles provides the proportionality provision as a guideline principle so that a countermeasure does not become excessive. Thus, no matter how effective the countermeasure is in inducing compliance, if it is not proportional, it will not be appropriate. ${ }^{100}$ Under Article 51 of the ILC Draft Articles, a countermeasure is proportional when it is commensurate with the injury suffered. In contrast, in the 1952 Netherlands case the Working Party stated that when applying the appropriateness standard in Article XXIII, an equivalence

\footnotetext{
${ }^{96}$ Palmeter and Alexandrov, above ch 1, n 63, at 650-655.

${ }^{97}$ Canada-Aircraft II (Article 22.6 - Canada), above ch 1, n 13, at [3.47]-[3.51].

${ }^{98}$ Ibid, at [3.119]-[3.122].

${ }^{99}$ Palmeter and Alexandrov, above ch $1 \mathrm{n}$ 63, at 655 .

${ }^{100}$ Ibid, at 655 .
} 
standard was adopted. ${ }^{101}$ Thus, the distance between "appropriate" and "equivalent" under GATT actually may not have been immense. ${ }^{102}$

I therefore suggest that one of the reasons why WTO law provides a non-punitive level of enforcement mechanism is to accommodate other purposes when the main purpose, inducing compliance, cannot be achieved.

\section{B A Non-Punitive Level of Enforcement Mechanism: the Current Design of Dispute Settlement Accommodating Other Purposes of Retaliation than Inducing Compliance}

By becoming Members of the WTO, states gain reciprocal benefits from WTO trade agreements and enjoy a high level of compliance through an effective dispute settlement mechanism. However, there are exogenous changes that might alter the cost and benefits of compliance, and the complexity or high political cost of compliance might lead a Member to not comply fully with its obligations.

The question is why the WTO drafters or negotiators designed a non-punitive enforcement mechanism (the weak back-up enforcement), but at the same time had a high preference for compliance. Some commentators have provided several answers to this question. Pauwelyn argues that mere compensation and proportional countermeasures (seemingly weak back-up enforcement) are sufficient as back-up enforcement for a property rule. These formal sanctions, together with community costs such as reputation, will provide sufficient incentive to comply with dispute settlement reports. ${ }^{103}$ Zimmermann also notes that the seemingly weak back-up enforcement, with its de facto toleration of temporary non-compliance, serves as a valuable systemic safety valve. ${ }^{104}$ Without discarding these arguments, this thesis argues that the non-punitive level of enforcement is designed to accommodate other purposes of retaliation besides inducing compliance.

\footnotetext{
${ }^{101}$ US - Suspension of Obligations, above ch 2, n 20, at 2.

102 Trachtman "WTO Cathedral", above n 46, at 136.

${ }^{103}$ Pauwelyn Optimal Protection of International Law, above n 48 at 150-157.

${ }^{104}$ Zimmermann, above n 90, at 402-405.
} 
At the intra-contractual commitments, WTO law offers several flexible rules under its provisions. Such flexible rules are provided due to the fact that in providing trade concessions, WTO Members have to deal with many complex issues such as domestic political sensitivity, the economic nature of concessions and unforeseen circumstances. At the extra-contractual commitments, Members still have to deal with various complexities in enforcing rulings, especially when the matter ruled on by the panel or the Appellate Body leads to high domestic political tension. In a situation where there is a high level of domestic political tension, a high level of enforcement (punitive sanction) would escalate the risk of a Member opting out of the system. Therefore, the DSU designs the enforcement level in such a way to keep Members within the WTO dispute settlement system. Hudec argues that all WTO Members are repeat players in the game, as they may have roles both as complainants and respondents. ${ }^{105}$ Therefore, Hudec has the view that: ${ }^{106}$

The optimum legal system is not simply the strongest legal system. It is the legal system that will be most helpful in enforcing one's trade agreement rights as complainant, while at the same time preserving the desired degree of freedom to deal with adverse legal rulings against one's own behaviour.

Having a weak back-up (non-punitive) enforcement mechanism does not undermine the WTO legal system. The fact that WTO dispute settlement enjoys a high level of compliance, despite having a non-punitive level of enforcement mechanism, shows basically that WTO Members are willing to comply with the DSB recommendations or rulings. The reasons for this phenomenon are that states are repeat players in the game (today's complainant may be tomorrow's respondent, or vice versa), and that they need to maintain their good reputation for future commitments.

Hence, realising the significance of having certain degree of flexibility, WTO retaliation, even though it has a strong preference for inducing compliance, does not have inducing compliance as its sole purpose. When inducing compliance seems not attainable, retaliation can serve other purposes: rebalancing and inducing a mutually agreeable solution or settlement.

\footnotetext{
${ }^{105}$ Hudec "Broadening the Scope of Remedies", above ch 1, n 14, at 377.

${ }^{106}$ Ibid.
} 
As pointed out by Zimmermann, the rules of the DSU indicate a preference for compliance but not at any cost. The weak back-up enforcement tolerates de facto, temporary non-compliance ("breach and pay"). ${ }^{107}$ The de facto toleration of temporary non-compliance demonstrates an extra-contractual flexibility and constitutes an important systematic safety valve for scenarios where WTO Members find it impossible to comply with the DSB's recommendations or rulings within the reasonable period of time. ${ }^{108}$ Put differently, the weak back-up enforcement is designed to accommodate the "rebalancing" purpose of retaliation. However, a WTO dispute can be terminated by either specific performance (compliance) or a mutually agreed solution. ${ }^{109}$ Malacrida put it clearly: "while the immediate aim of WTO retaliation is rebalancing, its ultimate aim is to induce compliance." ${ }^{110}$ In the next chapter, this thesis demonstrates that a mutually agreeable solution can also be the ultimate aim of WTO retaliation, as occurred in the $E C$-Hormones dispute.

\section{Summary}

The puzzle is almost complete. This thesis began by questioning the effectiveness and purposes of WTO retaliation in chapter two. Subsequently, chapter three conducted the search of the purposes of retaliation, and concluded that retaliation can pursue more than one purpose. Finally, chapter four assessed the multiple purposes of retaliation from the design of WTO treaty. In so doing, this chapter established three levels of assessment.

The first level of assessment carried out the analysis with regard to the nature of WTO entitlements. This level concluded that the bilateral nature of WTO dispute settlement and retaliation obligations provides parties to the dispute with the possibility of agreeing on other forms of settlement. The second level of assessment examined the protection rules of WTO entitlements. This level argued that WTO entitlements are protected by a property rule (high preference for compliance); nonetheless, WTO law does not provide punitive sanction as is

\footnotetext{
${ }^{107}$ Zimmermann, above n 90, at 402.

108 Ibid, at 404.

${ }^{109}$ The DSU, arts 3.6, 3.7, and 22.1.

${ }^{110}$ Malacrida, above ch $1, \mathrm{n} 28$, at 5.
} 
required by a property rule. This led us to the third level of assessment, in which this thesis provided that a non-punitive level of enforcement is designed to accommodate other purposes of retaliation. In short, the assessments in this chapter have established that the WTO treaty is designed in such a way so that it can accommodate the multiple purposes of retaliation. 


\section{CHAPTER FIVE}

\section{RETALIATION TO INDUCE A MUTUALLY AGREEABLE SOLUTION: A POSITIVE SETTLEMENT REACHED IN THE EC - HORMONES DISPUTE}

"The aim of the dispute settlement mechanism is to secure a positive solution to a dispute". 1

\section{OVERVIEW}

The WTO gives its Members the discretion to select their own domestic health policies; however in so doing, Members should apply their policies consistently with their WTO obligations. The EC - Hormones dispute is a dispute related to the health policies of the European Communities. The European Communities enacted a Directive that prohibited the importation and sale of hormone-treated beef and beef by-products throughout the European Communities. The United States and Canada challenged this directive, arguing that the European Communities violated its obligations under the GATT, the SPS Agreement and TBT Agreement. Both the panel and Appellate Body concluded that the European Communities were acting inconsistently with the SPS Agreement because the ban was not based on a risk assessment as required by the SPS Agreement. The EC-Hormones dispute is one example to elucidate how difficult it is to achieve compliance when it is related with a domestic sensitive issue, such as public health. Consequently, when the cost of compliance outweighs the cost of deviation, Members may opt to maintain the inconsistent measure and restore the political balance through retaliation.

This part discusses at first the implementation stage of the EC - Hormones dispute, particularly related to the retaliatory sanction against the failure of the European Communities to implement the recommendations or rulings. Subsequently, this part provides and elaborates on another purpose that retaliation can pursue. And finally, it responds to the question about the effectiveness of retaliation.

\footnotetext{
${ }^{1}$ The DSU, art 3.7.
} 
I EC-Hormones Dispute: Implementation Background

In EC - Hormones, although the European Communities (the respondent) always affirmed its intention to comply with the report adopted by the DSB, it seemed that it never intended to withdraw its measure. ${ }^{2}$ The European Communities' effort to comply was demonstrated from the actions pursued by the Commission.

After the decision of the DSB, the Commission immediately initiated a complementary risk assessment and funded several scientific studies and research projects on the six hormones involved in the dispute. ${ }^{3}$ The risk assessment conducted by the Scientific Committee on Veterinary Measures relating to Public Health (SCVPH) concluded that all six hormones have potentially adverse effects on human health, particularly for pre-pubertal children. However, the evidence is not equally conclusive for all hormones. ${ }^{4}$

In May 2001, the Commission proposed new legislation amending Council Directive 96/22/EC which suggests the complete ban of the use of oestradiol $17 \beta .{ }^{5}$ With regard to the other five hormones, although admitting that the current state of knowledge does not make it possible to give a quantitative estimate of the risk to consumers, the Commission proposed to continue to provisionally prohibit these hormones in accordance with Article 5.7 of the SPS Agreement.

Despite any risk assessment conducted by the European Communities, the United States and Canada (the complainants) viewed that the withdrawal of the inconsistent measures (the ban) was the only way to implement the DSB recommendations or rulings. The United States went

\footnotetext{
${ }^{2}$ Nicole C Lloyd "Beef Hormones Foster Animosity and Not Growth: An Analysis of the World Trade Organization Solving the United States' and European Communities' Beef Hormone Dispute" (2006) 25 Penn St Int'1 L Rev 557, 798. See also: European Communities - Measures Concerning Meat and Meat Products (Hormones) WTO DOC WT/DS26/17/Add.4, WT/DS48/15/Add.4 (11 May 1999) (Status Report by the European Communities).

${ }^{3}$ Proposal for a Directive of the European Parliament and of the Council Amending Council Directive 96/22/EC concerning the Prohibition on the Use in Stockfarming of certain Substances Having a Hormonal or Thyrostatic Action and of Beta-agonists [2000] COM (2000)0320 at 2.

${ }^{4}$ Report on the Proposal for a European Parliament and Council Directive Amending Council Directive 96/22/EC concerning the Prohibition on the Use in Stockfarming of certain Substances Having a Hormonal or Thyrostatic Action and of Beta-agonists [2001] EUR PARL DOC A5-0002/2001 at 14.

${ }^{5} \mathrm{COM}(2000) 0320$, above $\mathrm{n} 3$, at 6 .
} 
even further; infuriated by the European Communities' non-compliance, it adopted 'carousel retaliation' in $2000 .{ }^{6}$ However, when the European Communities threatened to seek to retaliate against the United States in the FSC dispute, the United States decided not to implement the carousel retaliation. $^{7}$

In October 2003, the European Communities announced their new legislation to the DSB and claimed that the new scientific evidence justified its ban. ${ }^{8}$ The European Communities argued that by enacting this Directive, it has fully implemented with the DSB recommendations, and thus required the United States and Canada to terminate the sanctions. The United States and Canada disagreed and denied that the new directive was based on science or that it implemented the DSB recommendations. Both also rejected the European Communities' request to initiate a compliance proceeding under Article 21.5. ${ }^{9}$ In November 2004, after the negotiation failed, the European Communities requested consultations with the United States and Canada. When the consultations also failed, the European Communities requested the establishment of a panel in January 2005 on the continued suspension of obligations in the EC-Hormones.

The following part addresses another purpose in pursuing retaliation - namely inducing a mutually agreeable solution. It explains the nature and features of this purpose and whether or not this purpose is feasible for WTO Members.

\footnotetext{
${ }^{6}$ Trade and Development Act Pub L No 106-200, § 407114 Stat 251.

${ }^{7}$ Taylor, above ch $1, \mathrm{n} 40$, at 366-367.

${ }^{8}$ Directive 2003/74/EC of the European Parliament and of the Council of 22 September 2003 amending Council Directive 96/22/EC concerning the prohibition on the use in stock farming of certain substances which have a hormonal or thyrostatic action and of beta-agonists [2003] O J L 262/17; European Communities - Measures Concerning Meat and Meat Products (Hormones) WTO DOC WT/DS26/22 WT/DS48/20 (28 October 2003) (Communication from the European Communities).

${ }^{9}$ United States - Continued Suspension of Obligations in the EC - Hormones Dispute WTO DOC WT/DS320/1 G/L/713 (10 November 2004) at [2] (Request for Consultations by the European Communities). See also: Dispute Settlement Body Minutes of Meeting held on 7 November 2003 WTO DOC WT/DSB/M/157 (18 December 2003) at 28-33.
} 


\section{Retaliation to Induce a Mutually Agreeable Solution as another Competing Purpose: The Settlement Reached in EC-Hormones}

The beef hormones dispute is one example of a conflict over compliance which lasted many years. The United States and Canada insisted on maintaining their retaliatory measures against certain EC products with the purpose of forcing the European Communities to comply with the WTO ruling by opening its market to hormone-treated beef. The European Communities, in contrast, insisted on maintaining its regulation banning hormone-treated beef, and on opening its market only to non-hormone-treated beef.

The beef hormones dispute is a complex dispute because it interacts with various sensitive aspects, such as public health protection, social and cultural expectations, domestic policy issues, producer and consumer interests, and so forth. Those aspects played a significant role in generating the disagreement and the difficulties over compliance. The United States, for instance, argued that the United States' beef is from cattle that are treated with approved growth hormones, and hence, does not cause any risk to public health. ${ }^{10}$ In contrast, the European Communities claimed that there are potential risks to human health associated with hormonetreated beef and beef products. ${ }^{11}$ However, the problem was that the European Communities' claim lacked an objective scientific risk assessment as required by the SPS Agreement. The ban was mostly derived from subjective domestic consumer fear and bad experiences in the past. ${ }^{12}$ The fear and experiences of the past have established a social-cultural perspective. The European Communities producers and consumers have a preference for naturally produced foods. The United States producers and consumers generally accept technological interference with food.

\footnotetext{
${ }^{10}$ Renee Johnson and Charles E Hanrahan "The US-EU Beef Hormone Dispute" (Congressional Research Service, 2010) at 9.

${ }^{11}$ Ibid, at 7.

${ }^{12}$ EC Measures Concerning Meat and Meat Products (Hormones) (Complaint by the United States) WTO DOC WT/DS26/R/USA (1997) at [8]-[9] (Report of the WTO Panel). In the history of events, the panel report described the illegal use of dethylstilboestrol (known as DES) in 1970 in veal production in France, and incidents in Italy where adolescent reportedly suffered from hormonal irregularity and the veal had been suspected as a possible cause.
} 
This favours the United States because the SPS Agreement requires technological risk assessment to support the protection of public health. ${ }^{13}$

In May 2009 the European Union and the United States signed a memorandum of understanding (MOU) implementing an agreement that promises to end this long-standing dispute. ${ }^{14}$ The memorandum sets up three phases in which the European Union agreed to expand its market access for the United States high quality beef, and the United States agreed to reduce its retaliatory duties levied on certain European Union exports. ${ }^{15}$ Hence, under this memorandum, the European Union would get to maintain its ban on the import of hormonetreated beef, but concurrently would provide a new tariff-free import quota for high-quality beef from the United States. ${ }^{16}$

The agreement itself received a positive response from the United States meat exporters. The United States Meat Exporter Federation, for instance, stated that the meat export activity under the new quota has been increasing very encouragingly and has had a positive impact on demand for high-quality US beef. ${ }^{17}$ During the DSB meeting, most WTO Members welcomed the European Union and the United States beef hormones solution agreement, even though most of the beef-exporting Members also demonstrated their fear regarding the definition of "highquality" beef as it might not provide equal market access to beef exporters, and therefore, could trigger another potential dispute under MFN treatment. ${ }^{18}$ The European Union, in responding to this concern, provided that this new quota would be "non-discriminatory" and "origin-neutral". 19

\footnotetext{
13 Isis Amelia Rose Sien "Beefing Up the Hormones Dispute: Problems in Compliance and Viable Compromise Alternatives" (2007) 95 Geo L J 565 at 575-579.

14 The European Union was established when the Maastricht Treaty entered into force on 1 November 1993 . The European Communities are one of the three pillars of the European Union. This thesis use these both terms (the European Union and European Communities) interchangeably.

${ }^{15}$ European Communities - Measures concerning Meat and Meat Products (Hormones) - Joint Communication from the European Communities and the United States WTO DOC WT/DS26/28 (30 September 2009).

${ }^{16}$ International Centre for Trade and Sustainable Development "New Issues Arise in EU-US Beef Trade Dispute" Bridges Weekly Trade News Digest Vol 13 No 23" (24 June 2009).

${ }^{17}$ US Meat Export Federation “International Market Development Activities for US Beef” Fourth Quarter FY09 (1 July - 30 September 2009) at 7.

${ }^{18}$ Dispute Settlement Body Minutes Meeting 19 June 2009 - Held in Centre William Rappard on 19 June 2009 WTO DOC WT/DSB/M/270 (28 August 2009) at 68.

${ }^{19}$ Ibid, at 76.
} 
In this dispute, retaliatory sanctions imposed by the United States would be terminated not because the European Communities removed its inconsistent measure, but because both states have reached and agreed upon a mutually satisfactory settlement. In other words, retaliation imposed by the United States has not induced the withdrawal of the inconsistent measure (compliance) but a mutually agreeable solution. Does the DSU allow such a solution? Does this kind of solution undermine the WTO dispute settlement system?

\section{A Retaliation With the Purpose of Inducing a Mutually Agreeable Solution}

The DSU does provide the legal basis for a dispute to be settled by the reaching of a mutually agreeable solution, and nothing under the DSU prevents such a solution from being reached at any stage of the dispute settlement, including at the implementation level. ${ }^{20}$ Article 22.8 of the DSU requires that retaliation shall be terminated upon the withdrawal of inconsistent measures, or upon the implementation of recommendations or rulings, or upon a mutually satisfactory solution being reached. Moreover, Article 3.7 of the DSU states that a solution mutually acceptable to the parties to a dispute and consistent with the covered agreements is clearly preferable.

"Consistent with the covered agreements" can be understood to mean that the measure should not violate WTO obligations stipulated under the covered agreements, and it should not nullify or impair the benefit of other WTO Members. This understanding enlightens the differences between "measure taken to comply" (compliance) and "mutually agreeable solution". A "measure taken to comply" is usually disputed by the parties to the dispute as the complainant often believes the measure still violates the violator's WTO obligations, and such a complaint is then brought before the Article 21.5 arbitration proceedings (compliance proceedings). However, a "mutually agreeable solution" is usually disputed by other Members who perceive that the solution reached by parties to the dispute has nullified or impaired their benefit. Such a complaint is brought under a new proceeding.

\footnotetext{
${ }^{20}$ The DSU, arts 3.6 and 3.7; see also Shadikhodjaev, above ch 2, n 7, at 24.
} 
This is one of the issues in US Hormone Suspension, also known as Hormones II, where the European Communities, instead of initiating Article 21.5 arbitration proceeding, started a new proceeding to determine where there had been compliance with the DSB's ruling and recommendation in Hormones $I^{21}$ The Appellate Body stated that the European Communities could have brought the complaint under Article 21.5 arbitration proceedings because either the implementing Member or the suspending Member can initiate the compliance proceeding. ${ }^{22}$

Therefore, the crucial thing for the parties to the dispute in reaching a mutually agreeable solution is to ensure that the solution does not nullify or impair other Members' trade interests. A measure that is consistent with WTO obligations but nullifies and impairs other Members' benefits is very much open to challenge. On the flip-side, WTO Members might be reluctant to initiate a proceeding for a measure that does not nullify or impair their benefit, even though the measure does not conform to WTO rules.

Every Member has the right to bring complaints on violations, or non-violations, or any complaints (standing) under the covered agreements. There is no requirement to provide evidence of the existence of "legal or economic interests", the presumed legal interest and economic interests are sufficient to initiate the proceedings. The Appellate Body in US - Wool Shirts and Blouses stated that "if any Member should consider that its benefits are nullified or impaired as result of circumstances set out in Article XXIII, then dispute settlement is available." ${ }^{, 23}$ Marceau points out the decision in Korea - Dairy in which the panel rejected the notion that evidence of any economic or legal interest must be provided before WTO proceedings can be initiated $;^{24}$ however, she also notes that in practice a Member must have some genuine interests to initiate the proceedings. ${ }^{25}$ This is understandable because the cost of initiating or having a dispute in the WTO is economically and politically substantial. A Member

\footnotetext{
${ }^{21}$ Catherina E Koops "Suspensions: To Be Continued" (2009) 36(4) Legal Iss Econ Integ 353 at 358.

${ }^{22}$ US - Continued Suspension (AB), above ch $1, \mathrm{n} 43$, at 347.

${ }^{23}$ US -Shirts and Blouses (AB), above ch 3, n 91, at [13].

${ }^{24}$ Korea - Definitive Safeguard Measure on Import of Certain Dairy Products WTO DOC WT/DS98/R (2000) at [7.14] (Report of the WTO Panel). Likewise, the Appellate Body in EC-Bananas III ruled that there is no "legal interest" requirement to have a standing before the WTO panel, see European Communities - Regime for the Importation, Sale and Distribution of Bananas WTO DOC WT/DS27/AB/R (1997) at [132] (Report of the Appellate Body).

${ }^{25}$ Gabrielle Marceau "WTO Dispute Settlement and Human Rights" (2002) 13(4) EJIL 753 at 758.
} 
would plausibly challenge a measure that inflicts a substantial adverse impact on its trade interests, or nullifies or impairs its benefits.

Article 3.8 of the DSU provides a presumption that a breach of the rules has an adverse impact on other Members, and it is up to the respondent Member to rebut such a charge. This presumption is reasonable because it is hard to imagine that there is cheating in trade deals that would not hamper other Members' trade benefits, opportunities, or expectations. Therefore, "nullification or impairment of benefit" is a significant element and its existence is presumed to exist in every infringement.

In sum, retaliatory measures can also be imposed with the purpose of achieving a mutually agreeable solution, and this action is possible under Articles 3.7 and 22.8 of the DSU. However the parties should design a solution that does not have a negative effect on, or discriminate against other Members' trade benefit, otherwise the solution will be able to be challenged in a new dispute. What happened in the EC-Hormones solution was that Members, in the DSB meetings, did not question the fact that the European Union still maintains its ban on hormone-treated beef without providing an objective risk assessment required by the SPS Agreement (non-withdrawal or non-implementation). Their concern was about whether the achieved solution would hurt their own trade benefits or interests. A mutually agreeable solution achieves a more politically sound rather than a legally sound settlement.

\section{B Retaliation Inducing a Mutually Agreeable Solution: Its Nature and Feature}

As with compliance, the achievement of a mutually agreeable solution terminates the retaliatory measures imposed by the retaliating state; however, an agreeable solution has a broader scope than compliance. Whereas inducing compliance under Article 19.1 of the DSU has the meaning of "bring[ing] the inconsistent measure into conformity", a mutually agreeable solution may come in the form of compensation (not only withdrawal). Nevertheless it has distinctions from compensation under Article 22.2 of the DSU. A mutually agreeable solution is a final remedy, while Article 22.2 of the DSU compensation is a temporary one. In other words, compensation under Article 22.2 does not replace the full implementation of bringing a measure 
into conformity. The memorandum between the United States and the European Union, which consists of three phases, offers a definitive solution that could be agreed upon under phase $3 .^{26}$ It opens the possibility of making the arrangement permanent, including in the case of the WTO hormone-treated beef dispute. ${ }^{27}$ In other words, if the arrangement between the United States and the European Union is working then it could lead to a permanent solution or settlement between them. Such a mutually agreed solution, consequently, would replace the implementation under Article 19 of the DSU, of bringing the inconsistent measure into conformity.

Furthermore, as long as the design would not result in a negative impact on other Members' trade interests, a mutually agreeable solution might reasonably be reached in various forms. The form of the arrangement offered by the EU in the beef hormones solution is a kind of compensation to offset the losses incurred due to its continuance of the prohibition on hormone treated beef. Therefore, a mutually agreeable solution paves the way for other forms of solutions to be reached in the future. Financial compensation is one possible form, although it might be less preferable than market access, because financial interests (in terms of cash) are not the major interests of the WTO Members. It is market access and fair treatment towards their products that are the main attractions for states in becoming part of the WTO system and rules.

\section{Retaliation Inducing a Mutually Agreeable Solution: A Defeat for the Winning Party?}

Article 3.7 of the DSU clearly elucidates a preference for settling disputes through a mutually agreeable solution. Nonetheless, this preference is also followed by another requirement that the solution shall be consistent with the WTO covered agreements and shall not nullify or impair benefits of other Members accruing under the agreement. ${ }^{28}$

\footnotetext{
${ }^{26}$ European Commission "WTO Dispute Settlement: Memorandum on Beef Hormones Dispute Signed with the United States" (Press Release, 14 May 2009).

${ }^{27}$ If both the United States and the European Union agree in phase 3 that the arrangement is working to their mutual satisfaction, it would lead to a final solution, in which the European Union would make permanent the 45,000 tons import quota for high-quality beef and the United States would remove the retaliatory duties, see International Centre for Trade Sustainable Development, "Truce Declared in Beef Hormone Dispute", News and Analysis Vol 3 No 2 (June 2009).

${ }^{28}$ The DSU, arts 3.5 and 3.7.
} 
Parties to the dispute can reach a mutually agreeable solution through bilateral negotiation or with the assistance of dispute resolution mechanisms such as good offices, conciliation or mediation. ${ }^{29}$ Even though it is a prerequisite that the parties to a dispute enter into bilateral negotiations before requesting the establishment of the panel, nothing in the DSU prohibits the parties from reaching a mutually agreeable solution at any stage of the dispute settlement process. For instance, the parties to the dispute reached a mutually agreeable solution prior to the issuance of the interim report in $U S-D R A M S$, or after the issuance but before the issuance of final report in EC-Scallops. ${ }^{30}$ In other cases, EC-Butter, the parties reached the solution after the issuance of the final report but before the circulation of the report to all Members. ${ }^{31}$ In Japan - Apples, the parties to the dispute reached a mutually agreeable solution after the issuance of the Article 21.5 panel report. ${ }^{32}$ As discussed above, recently, the European Union and the United States reached a mutually agreeable solution to end their long-standing dispute in $E C$ - Hormones after the imposition of retaliation.

Whereas reaching a mutually agreeable solution at the beginning of the dispute or prior to the issuance of the panel or Appellate Body final report would bring a win-win situation for both parties to the dispute, the benefit of achieving a mutually agreeable solution after the imposition of the retaliation measure is questionable from the side of the complainant or winning party side. The winning party seems not to obtain what is supposed to gain when winning the dispute. However, by ending a long dispute such as occurred in the EC-Hormones dispute, a mutually agreeable solution can be also perceived as bringing a positive result from the settlement of dispute point of view.

\footnotetext{
${ }^{29}$ A Handbook of the WTO Dispute Settlement System, above ch 1, n 4, at 92.

${ }^{30}$ Ibid, at 93.

31 Ibid.

32 Notification of Mutually Agreed Solution, Japan Measures Affecting the Importation of Apples WTO DOC WT/DS245/21 G/L/520/Add.1 G/SPS/GEN/299/Add.1 G/AG/GEN/50/Add.1 (2 September 2005).
} 
Bello, Pelzman and Shoham state that while the DSU improved the GATT rules for settling disputes, compliance remains an elective choice. ${ }^{33}$ The best option for the institution and complainant would be to have the respondent abide by the decision and come into compliance by withdrawing the inconsistent measure. ${ }^{34}$ In contrast, the best option from the respondent's perspective may be to continue to maintain the measure and provide compensation to the complainant; and the second-best-option may be to suffer retaliation. ${ }^{35}$

Whereas the best option for the institution and complainant would bring the dispute to an end, the best option for the respondent would prolong the dispute, as it would just provide compensation rather than resolving the dispute. However, a mutually agreeable solution, even reached after the threat of the imposition of retaliation, would bring a settlement of the dispute for both the complainant and respondent. The case of the EC hormone-treated beef demonstrates the reality that when compliance is not attainable, the best option for the complainant, the respondent, and even the institution, could be to reach a mutually agreeable solution to settle and end the dispute. That way neither party would retain the worse-off position any longer.

In sum, a mutually agreeable solution does not worsen the position of the winning party. It provides an alternative outcome when withdrawal of the inconsistent measure is not attainable. Inducing a mutually agreeable solution makes the system more fruitful and provides Members with some flexibility in settling their disputes within the framework of the WTO. Without any flexibility, Members may choose to opt out of the system. A lack of settlement would obviously undermine the WTO dispute settlement system and the favourable position of the winning party.

\footnotetext{
${ }^{33}$ Joseph Pelzman and Amir Shoham "WTO DSU - Enforcement Issues" in James C Hartigan (ed) Trade Disputes and the Dispute Settlement Understanding of the WTO: an Interdisciplinary Assessment (Emerald, 2009) at 370. See also Bello, above ch 1, n 80, at 646-647.

${ }^{34}$ Ibid, at 370 .

${ }^{35}$ Ibid.
} 


\section{Room for Deviation: The Question about the Effectiveness of WTO Retaliation}

As explained in chapter three, the purpose of retaliation has to be within the context of the aim and purpose of WTO dispute settlement. The purpose of inducing a mutually agreeable solution supports the aim of the WTO dispute settlement system by providing security and predictability, an aim stipulated under Article 3.2 of the DSU.

Several scholars such as Bello, Schwartz and Sykes argue that the respondent or violator state would maintain its inconsistent measure and pay compensation or suffer retaliation, rather than lose its domestic political credence by complying. They refer to suffering retaliation here for the purpose of rebalancing. The weakness of this scheme is that it prolongs the dispute. The lack of settlement would obviously undermine the security and predictability of WTO legal system and dispute settlement. A mutually agreeable solution provides a better solution for the system. They have the effect of adjustment, but, most importantly lead to the settlement of the dispute. When inducing compliance is too costly, retaliation can still be utilised as an instrument in bargaining a mutually agreeable solution.

Many Members have welcomed the mutually agreeable solution reached by the European Union and the United States in EC-Hormones, because the agreement is believed to provide a way to settle a dispute that has tasted for over 20 years. That settlement would obviously contribute positively to the aim of dispute settlement in providing security and predictability to the multilateral trading system.

A mutually agreeable solution is the result of a diplomatic or negotiated approach; it offers some flexibility in settling the dispute, and in EC-Hormones case it provides room for "legitimate" non-compliance. The existence of mutually agreeable solutions is necessary in order to strike the balance between the WTO as a diplomatic or negotiation based system and the WTO as a rule-based system. If the rules are too rigid or strict, Members would lose their interest in complying with the rules, or they would even ignore the rules. Some flexibility is important to 
keep Members in the system and to attract other non-Members to join the system. This explains why in the WTO there are no punitive sanctions.

Moreover as explained previously, inducing compliance is not the sole purpose of retaliation. In fact, the DSU demonstrates a preference for mutually agreeable solutions. Not only does the DSU state it as the preferable settlement at the consultations stage (prior to panel stage), but also provides the retaliation provision to generate this solution at the non-implementation stage. Therefore with regard to the question of effectiveness, even though in some circumstances retaliation may not achieve the purpose of inducing compliance, its existence is still sufficient to force a violator state to sit down and negotiate another kind of solution. The imposition of retaliation brings about a behavioural change in the violator state either by stopping the violation, or providing some kind of compensation/rebalancing, or agreeing to a solution.

As explained previously, although effectiveness and compliance are related concepts, the question of whether a rule is effective should be distinguished from the question of whether it is complied with. A rule can be effective even if the compliance with it is low. ${ }^{36}$ Gerhart explains further that effectiveness can be measured and assessed objectively, once the goals of the rule have been articulated; and that changes in behaviour can promote the goal of the rule. ${ }^{37}$ WTO retaliation contributes to changing the behaviour of the states so that they search for a positive settlement. No state wants to suffer retaliatory action for too long, no state wants to be labelled or to have a reputation as the "violator", therefore Members will either withdraw their inconsistent measures, or in the case that compliance is too costly, they will prefer to enter into mutually agreeable solutions. The presence of such behavioural changes of the parties to a dispute as a response to retaliation action demonstrates that WTO retaliation can be said to perform reasonably well even when it does not always induce compliance.

Finally, three disputes are presented here to illustrate the effectiveness of retaliation in the light of its multiple purposes. They are: Byrd - Amendment, US - Upland Cotton and EC -

\footnotetext{
${ }^{36}$ Raustiala states that if the rule can bring the desired change in behaviour, it can be considered effective even though non-compliance with the rule does exist. See Raustiala, above ch 3, n 7, at 394-398.

${ }^{37}$ Gerhart, above ch 3, n 7, at 362-363.
} 
Hormones disputes. In the Byrd - Amendment dispute, the United States passed the Deficit Reduction Act which repealed the Byrd Amendment as a respond to the retaliatory measures imposed by the European Communities, Japan, Canada and Mexico. The withdrawal of inconsistent measures is the evidence that retaliation has reached the purpose of inducing compliance. In the US - Upland Cotton dispute, retaliation (through its threat) has served the purpose of "rebalancing". In this case, Brazil and the United States have reached a provisional agreement in which the United States has agreed to provide a fund to support technical assistance and capacity building of Brazil's cotton farmers. In return, Brazil would suspend temporarily the imposition of the countermeasures. ${ }^{38}$ Finally as explained previously, retaliation inducing a mutually agreeable solution has occurred in the EC-Hormones dispute. The European Union and the United States has signed a three-phases agreement designed to end the retaliatory measures and the long-standing dispute between them. ${ }^{39}$

To sum up, I provide a figure that lists three purposes of retaliation as well as an example of the disputes in which retaliation has promoted these purposes.

Figure 3 the multiple purposes of retaliation as achieved in practice

\begin{tabular}{|l|l|l|l|}
\hline \multicolumn{1}{|c|}{ Retaliation Purposes } & \multicolumn{1}{|c|}{ Nature } & \multicolumn{1}{c|}{$\begin{array}{c}\text { Descriptions } \\
\text { (the goals) }\end{array}$} & $\begin{array}{c}\text { Disputes } \\
\text { (occurred in) }\end{array}$ \\
\hline Inducing compliance & Final & $\begin{array}{l}\text { Full implementation } \\
\text { withdrawal of the inconsistent } \\
\text { measures) }\end{array}$ & $\begin{array}{l}\text { US }- \text { Byrd } \\
\text { Amendment }\end{array}$ \\
\hline Rebalancing/Compensation & Temporary & $\begin{array}{l}\text { Re-balancing or compensation } \\
\text { (in the case of pending } \\
\text { compliance) }\end{array}$ & $\begin{array}{l}\text { US }- \text { Upland } \\
\text { Coton }\end{array}$ \\
\hline $\begin{array}{l}\text { A Mutually agreeable } \\
\text { solution }\end{array}$ & Final & $\begin{array}{l}\text { A mutual satisfactory solution } \\
\text { reached between parties to end } \\
\text { the dispute }\end{array}$ & \begin{tabular}{l} 
EC-Hormones \\
\hline
\end{tabular} \\
\hline
\end{tabular}

\footnotetext{
${ }^{38}$ Schnepf, above ch 2 , n 178, at 24-27.

${ }^{39}$ WT/DS26/28, above n 15.
} 
Even though this thesis posits arguments about the reasonable soundness of WTO retaliation in light of its multiple purposes, there is still room for improvement. On the one hand, the WTO has single retaliatory instrument, namely the suspension of concessions or other obligations. On the other hand, the WTO covers various trade issues and consists of many Members with different trade capacities. Single instrument, even though it can pursue more than one purpose, might prove problematic in several complex situations, such as inequalities or asymmetric power between states.

The imposition of retaliation is known to be harmful to both complainant and respondent states, because retaliation in the form of suspension of concessions or other obligations is trade restrictive (which is why it is never preferred in the first place). Nevertheless, states with various trade areas (developed countries) can design retaliation to hit significant sectors or products of violator states, while not causing too much harm to its domestic producers or its trade. However for small developing or least-developed countries that only have one or limited trade sector, more problems will be faced in imposing retaliation measures.

Why does the WTO centralise its retaliation measure on the suspension of concessions or other obligations? Tietje suggests that the rationale for this can be derived from the notion of a concession based on a mercantilism view, and that the GATT was established on this mercantilism thought: exchanging concessions, such as market access, reciprocally. ${ }^{40}$ Mercantilism always attempts to maximise exports and minimise imports. Accordingly, those exchanging concessions have been concerned with the exporters' interests, and retaliation reverses this exporter-oriented view by closing its market to another party that has failed to perform its obligation to open its market. ${ }^{41}$

\footnotetext{
${ }^{40}$ Christian Tietje "The WTO Sanctions Regime and International Constitutional Political Economy: a Comment on the Case against Reforming the WTO Sanctions Regime” (2008) 1 U Ill L Rev 383 at 384-385.

${ }^{41}$ Ibid, at 385 .
} 
The suspension of concessions or other obligations is the most credible sanction if the focus is on export group pressure. However, WTO law is not only about exchanging concessions and is no longer merely concerned with the exporters' interests. This explains why the suspension of concessions seems toothless in inducing compliance in several disputes related to public health concerns, such as in EC-Hormones, and social interests, such as in EC-Bananas $I I I .^{42}$ The injured party might employ suspension as an instrument to rebalance the concessions; however it might not provide proper relief to the injured export groups. Put differently, the suspension alone cannot be expected to satisfy all interests and to solve all the underlying problems.

So, even though WTO retaliation is an effective instrument in changing the behaviour of states which flout the law, one should not expect that it go beyond that, to be a perfect instrument, because the suspension alone is not sufficient.

\section{Summary}

This chapter introduced another purpose of retaliation that was reflected in the $E C$ Hormones dispute: inducing mutually agreeable solution. In assessing this purpose, firstly the chapter showed that Article 22.8 and 3.7 of the DSU provide a legal basis for this purpose to be pursued by the parties to the dispute. However the parties should design a mutually agreeable solution that does not adversely affect or discriminate against other Members' trade benefits, otherwise the solution would be able to be challenged in a new dispute. Secondly, I argued that this purpose is the best alternative or option for the parties to the dispute when the purpose of inducing compliance is not attainable, because it provides parties with some flexibility in settling their dispute (not prolonging the dispute).

\footnotetext{
${ }^{42}$ Ibid, at 386.
} 
With regard to the question of effectiveness, I concluded that although in some circumstances WTO retaliation might not achieve the purpose of inducing compliance, it does induce several changes in the behaviour of a violator state in seeking and pursuing the purposes or goals of retaliation including a positive settlement through a mutually agreeable solution. The presence of such behavioural changes of the parties to a dispute as a response to retaliation action demonstrates that WTO retaliation has a reasonably sound level of performance. 


\section{CHAPTER SIX}

\section{CONCLUSION}

Conclūdō: to make an end; conclude. ${ }^{1}$

The maxim "Ubi jus ibi remedium" demonstrates the importance of having legal remedies in every legal system. Every dispute settlement system requires effective enforcement instruments and mechanisms, nevertheless "harmful" and "ineffective" may be the words that come to mind when someone hears the words "WTO retaliation".

This thesis began with the discontent of various commentators over the WTO remedies, particularly retaliation. In their view, imposing retaliation is like "shooting [oneself] in the foot", and it does little or nothing to induce compliance. Therefore, they consider it ineffective (chapters one and two).

It is often assumed that a high level of compliance indicates the effectiveness of the compliance rule. I nonetheless identified that compliance and effectiveness, although related, are distinct. Therefore simple compliance is not an adequate measure of effectiveness. I established a different standpoint in this thesis that a rule is considered effective if it can achieve its purposes or objectives. Consequently, the effectiveness of WTO retaliation should be assessed in the light of its purposes (chapter three).

In seeking the purposes of retaliation, I conducted an interpretation of Article 22 of the DSU in accordance with the rules of treaty interpretation. This is consistent with Article 3.2 of the DSU which provides that the WTO Agreements are to be interpreted in accordance with customary rules of interpretation of public international law. The customary rules of interpretation are widely regarded as being codified in Articles 31 and 32 of the VCLT.

\footnotetext{
${ }^{1}$ Oxford Latin Dictionary, above ch 4, n 8, at 389-390.
} 
The interpretation of Article 22 has two results: firstly, retaliation should not turn into an arbitrary measure in pursuing its objectives; secondly, retaliation can be used to pursue more than one purpose in the light of the object and purpose of WTO dispute settlement (chapter three).

I also looked at the Article 22.6 arbitrators' statements in search of the purposes of retaliation. In most disputes, the arbitrators referred to inducing compliance as the purpose of retaliation, even though they employed different standards in calculating the level of retaliation for the prohibited subsidies disputes. There were two disputes in which the arbitrators questioned the exclusivity of the purpose of inducing compliance. Moreover, I assessed various academic writings with regard to the purpose of retaliation. These writings can be divided into two main schools of thought: the purpose of inducing compliance, and the purpose of rebalancing. Those who support the purpose of rebalancing have written that when the cost of political performance exceeds the benefit of performance (politically cost), the DSU allows a violator to continue a violation as long as the violator compensates or is willing to suffer retaliation. This thought is refuted by the proponents of inducing compliance (chapter three).

The study in this thesis has demonstrated that commentators as well as the arbitrators endorse the single purpose of retaliation: either inducing compliance or rebalancing. Commentators have had in fact a long debate about the single purpose of retaliation. Interpretation of Article 22 which I undertook has demonstrated that there are multiple purposes of retaliation, and they are: inducing compliance, rebalancing and reaching a mutually satisfactory solution. In the light of these multiple purposes, I stated that the disagreements about the single purpose of retaliation are unnecessary (chapter three).

Furthermore one may argue that the interpretation alone is not sufficient to support this stance; therefore I provided assessments of the design of the WTO treaty to support the multiple purposes arguments. The assessments of the WTO treaty design have offered two primary conclusions: firstly, the bilateral nature of the WTO dispute settlement and retaliation entitlements provides the Members with the possibility of agreeing on other forms of settlement. Secondly, even though the WTO entitlements are basically protected by a property rule (high 
preference for compliance), the WTO provides a lower level of back-up enforcement mechanism (non-punitive sanctions). This lower level of enforcement mechanism is to accommodate purposes additional to inducing compliance (chapter four).

With regard to the multiple purposes, I have identified the purpose of retaliation inducing a mutually agreeable solution in the $E C$ - Hormones dispute. The United States would terminate the retaliatory measures not because of the removal of inconsistent measures by the European Union, but because both states have agreed upon a mutually satisfactory settlement. I argued that this purpose (reaching a mutually agreeable solution) is the best-alternative-option when the purpose of inducing compliance is not attainable (chapter five).

To conclude, in several disputes retaliation may not induce compliance; it may nevertheless induce changes in the behaviour of the violator state as is evidenced by the parties seeking and pursuing other goals from retaliation such as a positive settlement through a mutually agreed solution. It is therefore concluded that even if it does not always induce compliance, WTO retaliation is effective in the light of its multiple purposes. 


\section{BIBLIOGRAPHY}

\section{Books}

Alavi, Amin Legalization of Development in the WTO between Law and Politics (Wolters Kluwer Law and Business, 2009)

Bermann, George A and Mavroidis, Petros C (eds) WTO Law and Developing Countries (Cambridge University Press, 2007)

Bown, Chad P and Pauwelyn, Joost The Law, Economics and Politics of Retaliation in WTO Dispute Settlement (Cambridge University Press, 2010)

Bronckers, Marco and Quick, Reinhard (eds) New Directions in International Economic Law: Essays in Honour of John H. Jackson (Kluwer Law International, 2000)

Dam, Kenneth W The GATT: Law and International Economic Organization (the University of Chicago Press, 1970)

Garner, Bryan A (ed) Black’s Law Dictionary (7th ed, West Group, 1999)

Glare, P G W (ed) Oxford Latin Dictionary (Oxford University Press, 1982)

Hartigan, James C (ed) Trade Disputes and the Dispute Settlement Understanding of the WTO: an Interdisciplinary Assessment (Emerald, 2009)

Hoekman, Bernard M, Mattoo, Aaditya and English, Philip (eds) Development, Trade, and the WTO: A Handbook (the World Bank, 2002)

Hudec, Robert E The GATT Legal System and World Trade Diplomacy (2nd ed, Butterworth Legal Publishers, 1990)

Jackson, John H World Trade and the Law of GATT (Bobbs-Merrill, 1969)

Kennedy, Daniel L M and Southwick, James D (eds) The Political Economic of International Trade Law (Cambridge University Press, 2002)

Lawrence, Robert Z Crimes \& Punishments? Retaliation under the WTO (Institute for International Economics, 2003)

Long, Olivier The GATT and Its Limitation in the GATT Multilateral Trade System (Martinus Nijhoff Publishers, 1987) 
Mitchell, Andrew D Legal Principle in WTO Disputes (Cambridge University Press, 2008)

Orakhelashvili, Alexander Peremptory Norms in International Law (Oxford University Press, 2006)

Ortino, Federico and Petersmann, Ernst-Ulrich The WTO Dispute Understanding Settlement System 1995-2003 (Kluwer Law International, 2004)

Palmeter, David and Mavroidis, Petros C Dispute Settlement in the World Trade Organization: Practice and Procedure (2nd ed, Cambridge University Press, 2004)

Pauwelyn, Joost Conflict of Norms in Public International Law: How WTO Law Relates to Other Rules of International Law (Cambridge University Press, 2003)

Pauwelyn, Joost Optimal Protection of International Law - Navigating between European Absolutism and American Voluntarism (Cambridge University Press, 2008)

Qureshi, Asif H Interpreting WTO Agreement: Problems and Perspectives (Cambridge University Press, 2006)

Ragazzi, Maurizio The Concept of International Obligations Erga Omnes (Oxford University Press, 1997)

Shadikhodjaev, Sherzod Retaliation in the WTO Dispute Settlement (Kluwer Law International, 2009)

Sinclair, Ian McTaggarat Vienna Convention on the Law of Treaties (Manchester University Press, 1984)

Steger, Debra P Peace through Trade: Building the World Trade Organization (Cameron May, 2004)

Stewart, Terence P (ed) The GATT Uruguay Round: A Negotiating History (1986-1992) Volume IIb: Commentary (Kluwer Law and Taxation Publishers, 1995)

Tams, Christian $\mathrm{J}$ Enforcing Obligation Erga Omnes in International Law (Cambridge University Press, 2005)

Trebilcock, Michael $\mathrm{J}$ and Howse, Robert The regulation of International Trade (3rd ed, Routledge, 2005)

Van den Bossche, Peter The Law and Policy of the World Trade Organization: Text, Cases and Materials (Cambridge University Press, 2005) 
Van Hoecke, Mark (ed) Methodologies of Legal Research: Which Kind of Method for What Kind of Discipline? (2011, Hart Publishing)

Weiss, Edith B and Jacobson, Harold K (eds) Engaging Countries: Strengthening Compliance with International Environmental Accords (MIT Press, 2000)

Wilcox, Clair A charter For World Trade (the Macmillan Company, 1949)

World Trade Organization Secretariat A Handbook on the WTO Dispute Settlement System: A WTO Secretariat Publication prepared for publication by the Legal Affairs Division and the Appellate Body (Cambridge University Press, 2004)

World Trade Organization Secretariat Guide to GATT Law and Practice (1965) Volume 2 Article XXII-XXXVIII (Geneva, WTO, 1995)

Zimmermann, Thomas A Negotiating the Review of the WTO Dispute Settlement Understanding (Cameron May, 2006)

\section{Articles}

Alavi, Amin “African Countries and the WTO's Dispute Settlement Mechanism" (2007) 25(1) Development Policy Review 25

Alvarez, Jose E “Foreword Why Nations Behave” (1998) 19 Mich J Int'1 L 19

Anderson, Kym "Peculiarities of Retaliation in WTO Dispute Settlement" (2002) 1(2) WTR 123

Araki, Ichiro "Comment on Fritz Breuss "WTO Dispute Settlement: An Economic Analysis of Four EU-US Mini Trade Wars" (2004) J Ind Compet Trade 345

Bello, Judith "The WTO Dispute Settlement Understanding: Less is More" (1996) 90 Am J Int'1 L 416

Bermann, Suzanne "EC-Hormones and the Case for an Express WTO Postretaliation Procedure" (2007) 107 Colum L Rev 131

Bronckers, Marco and van den Broek, Naboth "Financial Compensation in the WTO: Improving the Remedies of WTO Dispute Settlement" (2005) 8(1) JIEL 101

Calebresi, Guido and Melamed, A Douglas "Property Rules, Liability Rules, and Inalienability: One View of the Cathedral" (1972) 85 Harv L Rev 1089

Carmody, Chios "WTO Obligations as Collective" (2006) 17(2) EJIL 419. 
Charnovitz, Steve “Rethinking WTO Trade Sanctions” (2001) 95(4) Am J Int'l L 792

Charnovitz, Steve "Should the Teeth be Pulled?: An Analysis of WTO Sanctions" in Daniel L. M. Kennedy and James D. Southwick (eds) Political Economy of International Trade Law: Essays in Honor of Robert E. Hudec (Cambridge University Press, 2002) 602

Charnovitz, Steve “The WTO’s Problematic "Last Resort” against Noncompliance” (2002) 57(4) Aussenwirtschaft 409

Chayes, Abram and Chayes, Antonia Handler "On Compliance" (1993) 47(2) International Organization 175

Cho, Sungjoon "The Nature of Remedies in International Trade Law" (2003) 65 U Pitt L Rev 763

Choi, Won-Mog "To Comply or Not to Comply? - Non-implementation Problems in the WTO Dispute Settlement System” (2007) 41(5) JWT 1043

Collins, David "Efficient Breach, Reliance and Contract Remedies at the WTO” 43 (2009) JWT 225

Davey, William J “Compliance Problems in WTO Dispute Settlement” (2009) 42 Cornell Int'l L J 119

Davey, William J “The WTO Dispute Settlement System: The First Ten Years” (2005) 8 JIEL 17

Diego-Fernandez, Mateo "Compensation and Retaliation: A Developing Country's Perspective" in George A Bermann and Petros C Mavroidis (eds) WTO Law and Developing Countries (Cambridge University Press, 2007)

Downs, George W and Jones, Michael A "Reputation, Compliance, and International Law" (2002) 31 JLS S95

Ehring, Lothar “The European Community's Experience and Practice in Suspending WTO Obligations" in Chad P Bown and Joost Pauwelyn (eds) The Law, Economics and Politics of Retaliation in WTO Dispute Settlement (Cambridge University Press, 2010) 244

Fukunaga, Yuka "Securing Compliance through the WTO Dispute Settlement System: Implementation of DSB Recommendations" (2006) 9 JIEL 383

Gazzini, Tarcisio "The Legal Nature of WTO Obligations and the Consequences of their Violation" (2006) 17(4) EJIL 723

Gerhart, Peter M "Reflection: Beyond Compliance Theory - TRIPS as a Substantive Issue" (2000) 32 Case W Res J Int'l Law 352 
Goh, Gavin and Ziegler, Andreas R "Retrospective Remedies in the WTO after Automotive Leather" (2003) 6(3) JIEL 545

Grané, Patricio “Remedies under WTO” (2001) JIEL 755

Green, Andrew and Trebilcock, Michael "Enforcing WTO Obligations: What We Learn From Export Subsidies?" (2007) 10 JIEL 653

Hartmann-Trofer, Simone "Antidumping and Countervailing Duties: the Byrd Amendment" (2008) 11 Int'1 Trade \& Bus L Rev 287

Holmes, Oliver Wendell "The Path of the Law” (1897) 10 Harv L Rev 457

Howse, Robert and Neven, Damien J 'United States - Tax Treatment for 'Foreign Sales Corporations' Recourse to Arbitration by the United States under Article 22.6 of the DSU and Article 4.11 of the SCM Agreement (WT/DS108/ARB): A Comment" (2005) 4 WTR 101

Hudec, Robert E "Broadening the Scope of Remedies in WTO Dispute Settlement" in Friedl Weiss (ed) Improving WTO Dispute Settlement Procedures: Issues and Lesson from the Practice of Other International Courts and Tribunals (Cameron May, 2000) 369

Hudec, Robert E "Industrial Subsidies: Tax Treatment of 'Foreign Sales Corporation"” in ErnstUlrich Petersmann and Mark A Pollack (eds) Transatlantic Economic Dispute: the EU, the US and the WTO (Oxford University Press, 2003) 175

Hudec, Robert E "The Adequacy of WTO Dispute Settlement Remedies: A Developing Countries Perspective" in Bernard M Hoekman, Aaditya Mattoo, Philip English (eds) Development, Trade, and the WTO: A Handbook (the World Bank, 2002)

Hudec, Robert E “The GATT Legal System: A Diplomat’s Jurisprudence” (1970) 4 JWTL 615

Islam, M Rafiqul "Recent EU Trade sanctions on the US to Induce Compliance with the WTO Ruling in the Foreign Sales Corporation Case: Its Policy Contradiction Revisited" (2004) 38(3) JWT 471

Jackson, John H "International Law Status of WTO Dispute Settlement Reports: Obligation to Comply or Option to "Buy Out"” (2004) 98 Am J Int'1 L 109

Jackson, John H "The WTO Dispute Settlement Understanding - Misunderstandings on the Nature of Legal Obligations (responding to Bello's article)" (1997) 91 Am J Int'L L 60

Jacobson, Harold K and Weiss, Edith B "A Framework for Analysis" in Edith B. Weiss and Harold K Jacobson (eds) Engaging Countries: Strengthening Compliance with International Environmental Accords (MIT Press, 2000) 
Kessie, Edwini "The 'Early Harvest Negotiation' in 2003" in Federico Ortino and Ernst-Ulrich Petersmann (eds) The WTO Dispute Settlement System 1995-2005 (Kluwer Law International, 2004)

Koh, Harold Hongju “Why Do Nations Obey international Law?" (1997) 106 Yale L J 2599

Koops, Catharina E “Suspensions: To Be Continued” (2009) 36(4) Legal Iss Econ Integ 353

Kotera, Akira "On the Legal Character of Retaliation in the World Trade Organization System" in Nisuke Ando, Edward McWhinney, Rüdiger Wolfrum Liber Amicorum Judge Shigeru OdaVol 2 (Kluwer Law International, 2002)

Kuyper, Pieter Jan "Remedies and Retaliation in the WTO: Are They Likely to be Effective? The State Perspective and the Company Perspective" (1997) 91 Am Soc'y Int'l L Proc 282

Lindroos, Anja and Mehling, Michael "Dispelling the Chimera of 'Self-Contained Regimes' International Law and the WTO" (2006) 16(5) EJIL 857

Lloyd, Nicole C "Beef Hormones Foster Animosity and Not Growth: An Analysis of the World Trade Organization Solving the United States' and European Communities' Beef Hormone Dispute" (2006) 25 Penn St Int'l L Rev 557

Malacrida, Reto "Toward Sounder and Fairer WTO Retaliation: Suggestions for Possible Additional Procedural Rules Governing Members' Preparation and Adoption of Retaliation Measures" (2008) 42(1) JWT 3

Marceau, Gabrielle "WTO Dispute Settlement and Human Rights" 13(4) EJIL 753

Mavroidis, Petros C "Remedies in the WTO Legal System: Between a Rock and a Hard Place" (2000) 11 EJIL 763

McGivern, Brendan P "Seeking Compliance with WTO Rulings: Theory, Practice and Alternatives" (2002) 36 Int'l Lawyer 141

McLachlan, Campbell "The Principle of Systemic Integration and Article 31(3)(c) of the Vienna Convention" (2005) 54 Int'l\&Comp L Q 279

McRae, Donald "Measuring the Effectiveness of the WTO Dispute Settlement System" (2008) 3(1) AJWH 1

McRae, Donald "The Contribution of International Trade Law to the Development of International Law" (1996) 260 Recueil des Cours 109 
Mendel, Mark E "Retaliation in the WTO: The Experience of Antigua and Barbuda in USGambling" in Chad P Bown and Joost Pauwelyn (eds) The Law, Economics and Politics of Retaliation in WTO Dispute Settlement (Cambridge University Press, 2010)

Mercurio, Bryan "Improving Dispute Settlement in the World Trade Organization: The Dispute Settlement Understanding Review - Making It Work?” (2004) 38(5) JWT 795

Mercurio, Bryan "Retaliatory Trade Measure in the WTO Dispute Settlement Understanding: Are There Really Alternative?" in James C Hartigan (ed) Trade Disputes and the Dispute Settlement Understanding of the WTO: An Interdisciplinary Assessment (Emerald, 2009) 397

Mercurio, Bryan "Why Compensation Cannot Replace Trade Retaliation in the WTO Dispute Settlement Understanding" (2009) 8(2) WTR 315

Mitchell, Andrew D "Proportionality and Remedies in WTO Disputes" (2006) 17 EJIL 985

Nzelibe, Jibe "The Credibility Imperative: The Political Dynamics of Retaliation in the World Trade Organization's Dispute Resolution Mechanism" 6 (2005) Theo Inq L 215

Nzelibe, Jide "The Case against Reforming the WTO Enforcement Mechanism" (2008) U Ill L R 319

O'Connor, Bernard "Remedies in the World Trade Organization Dispute Settlement System The Bananas and Hormones Cases" (2004) 38(2) JWT 245

Palmeter, David "The WTO Dispute Settlement Mechanism: Compliance with WTO Rulings and other Procedural Problems" (2001) 4 JWIP 291

Palmeter, David and Alexandrov, Stanimir “"'Inducing Compliance” in WTO Dispute Settlement" in Daniel L. M. Kennedy and James D. Southwick (eds) The Political Economic of International Trade Law (Cambridge University Press, 2002) 646

Pauwelyn, Joost "A Typology of Multilateral Treaty Obligations: Are WTO Obligations Bilateral or Collective in Nature?" (2003) 14(5) EJIL 907

Pauwelyn, Joost "Calculation and Design of Trade Retaliation: What is the Goal of Suspending WTO Obligations?" in Chad P Bown and Joost Pauwelyn (eds) The Law, Economic and Politics of Retaliation in WTO Dispute Settlement (Cambridge University Press, 2010)

Pauwelyn, Joost "Enforcement and Countermeasures in the WTO: Rules are Rules - Toward a More Collective Approach” (2000) 94 Am J Int'l L 335

Pauwelyn, Joost "The Role of Public International Law in the WTO" (2001) 95 Am J Int'l L 535 
Pelzman, Joseph and Shoham, Amir "WTO DSU - Enforcement Issues" in James C Hartigan (ed) Trade Disputes and the Dispute Settlement Understanding of the WTO: an Interdisciplinary Assessment (Emerald, 2009)

Perez-Motta, Eduardo and Diego-Fernandez, Mateo "If the DSU is "Working Reasonably Well", Why Does Everybody Want to Change it?" in Kim van der Borght and Dencho Georgiev (eds) Reform and Development of the WTO Dispute Settlement System (Cameron May, 2006)

Raustiala, Kal "Compliance and Effectiveness in International Regulatory Cooperation" (2000) 32 Case W Res J Int'L L 387

Rosas, Allan "Implementation and Enforcement of WTO Dispute Settlement Findings: An EU Perspective" (2001) 4 JIEL 131

Schwartz, Warren F and Sykes, Alan O "The Economic Structure of Renegotiation and Dispute Resolution in the World Trade Organization" (2002) 31 J Legal Stud 179

Sebastian, Thomas "The Law of Permissible WTO Retaliation" in Chad Brown and Joost Pauwelyn (eds) The Law, Economics and Politics of Retaliation in WTO Dispute Settlement (Cambridge University Press, 2010)

Sebastian, Thomas "World Trade Organization Remedies and the Assessment of Proportionality: Equivalence and Appropriateness" (2007) 48 Harv Int'l L J 337

Shadikhodjaev, Sherzod and Park, Nohyoung "Cessation and Reparation in the GATT/WTO Legal System: A View from Law of State Responsibility" 41(6) JWT (2007) 1237

Shaffer, Gregory and Ganin, Daniel "Extrapolating Purpose from Practice: Rebalancing or Inducing Compliance in Chad P Bown and Joost Pauwelyn (eds) The Law, Economics and Politics of Retaliation in WTO Dispute Settlement (Cambridge University Press, 2010) 73

Sicilianos, Linos-Alexander "The Classification of Obligations and the Multilateral Dimension of the Relations of International Responsibility" (2002) 13(5) EJIL 1127

Sien, Isis Amelia Rose "Beefing Up the Hormones Dispute: Problems in Compliance and Viable Compromise Alternatives" (2007) 95 Geo L J 565

Simma, Brunno and Pulkowski, Dirk "Of Planets and the Universe: Self-Contained Regimes in International Law” (2006) 17(3) EJIL 483

Slater, Gabriel L "The Suspension of Intellectual Property Obligations under TRIPS: A Proposal for Retaliating against Technology-Exporting Countries in the World Trade Organization" (2009) 97 Geo L J 1365 at 1371 
Spadano, Lucas Eduardo F A "Cross-agreement Retaliation in the WTO Dispute Settlement System: An Important Enforcement Mechanism for Developing Countries?" (2008) 7(3) WTR 511

Spamann, Holger "The Myth of 'Rebalancing' Retaliation in WTO Dispute Settlement Practice" 9(1) JIEL 31

Steger, Debra P "Commentary on the Doha Round: Institutional Issue" (2005) 5(4) Global Econ $\mathrm{J} 1$

Steger, Debra P "The Culture of the WTO: Why It Needs to Change" (2007) 10(3) JIEL 483

Subramanian, Arvind and Watal, Jayashree "Can TRIPS Serve as an Enforcement Device for Developing Countries in the WTO?" (2000) 3 JIEL 403

Sykes, Alan O "Comment on Chapter 2" in Chad P Bown and Joost Pauwelyn (eds) The Law, Economic and Politics of Retaliation in WTO Dispute Settlement (Cambridge University Press, 2010) 70

Sykes, Alan O "The Remedy for Breach of Obligations under the WTO Dispute Settlement Understanding: Damages or Specific Performance?" in Marco Bronckers and Reinhard Quick (eds) New Directions in International Economic Law: Essays in Honour of John H. Jackson (Kluwer Law International, 2000) 347

Taylor, C O'Neal "Impossible Cases: Lessons from the First Decade of WTO Dispute Settlement" (2007) 28 U Pa J Int'l Econ L 309

Tietje, Christian "The WTO Sanctions Regime and International Constitutional Political Economy: a Comment on the Case against Reforming the WTO Sanctions Regime" (2008) 1 U Ill L Rev 383

Trachtman, Joel P “The Domain of WTO Dispute Resolution” (1999) 40(2) Harv Int'1 L J 333

Trachtman, Joel P “The WTO Cathedral” (2007) 43 Stan J Int'l L 127

Udombana, Nsongurua J "A Question of Justice: the WTO, Africa, and Countermeasures for Breaches of International Trade Obligations" (2005) 38 J Marshall L Rev 1153

Van den Broek, Naboth "Power Paradoxes in Enforcement and Implementation of World Trade Organization Dispute Settlement Reports: Interdisciplinary Approaches and New Proposals" (2003) 37(1) JWT 127

Wilson, Bruce "Compliance by WTO Members with Adverse WTO Dispute Settlement Rulings: The Record to Date" (2007) 10(2) JIEL 397 
Yang, Pei-Kan "Some Thoughts on a Feasible Operation of Monetary Compensation as an Alternative to Current Remedies in the WTO Dispute Settlement" (2008) 3 Asian J WTO\&Int'1 Health L\&Pol'y 423

Yenkong, Ngangjoh H "World Trade Organization Dispute Settlement Retaliatory Regime at the Tenth Anniversary of the Organization: Reshaping the "Last Resort" Against Non-Compliance" (2006) 40(2) JWT 365

Young, Oran R and Levy, Marc A "The Effectiveness of International Environmental Regimes" in Oran R Young (ed) The Effectiveness of International Environmental Regimes: Causal Connections and Behavioral Mechanism (MIT Press, 1999)

Zimmermann, Claus D “Toleration of Temporary Non-Compliance: The Systemic Safety Valve of WTO Dispute Settlement Revisited" 3(2) (2011) Trade L \& Dev 382

\section{Theses, Weekly Articles, Working, Research and Seminar Papers}

Abbot, Frederick M "Cross-Retaliation in TRIPS: Options for Developing Countries" (International Centre for Trade and Sustainable Development Issue Paper No 8, April 2009)

Bagwell, Kyle "Remedies in the WTO: An Economic Perspective" (Columbia University Department of Economics Discussion Paper No 0607-09, January 2007)

Eleso, Adebukola A "WTO Dispute Settlement Remedies: Monetary Compensation as an Alternative for Developing Countries" (2006) Bepress Legal Series Paper 1378

Horn, Henrik, Maggi, Giovanni and Staiger, Robert W "The GATT/WTO as an Incomplete Contract" (Mimeo, 2006)

Johnson, Renee and Hanrahan, Charles E "The US-EU Beef Hormone Dispute" (Congressional Research Service, 19 January 2010)

Pauwelyn, Joost "How Strongly We Protect and Enforce International Law" (Duke Law School Faculty Scholarship Series NELLCO, 2006)

Plasai, Virachai "Compliance and Remedies against Non-Compliance under the WTO System: Towards a More Balanced Regime for All Members" (International Centre for Trade and Sustainable Development, June 2007)

Schnepf, Randy Brazil's WTO Case against the US Cotton Program (Congressional Research Service, 5 January 2011) 
Schropp, Simon A B "Revisiting the "Compliance -vs.- Rebalancing" Debate in WTO Scholarship: Towards a Unified Research Agenda" (HEI Working Paper No 29, Graduate Institute of International Studies, 2007)

Schropp, Simon A B "Trade Policy Flexibility and Enforcement in the WTO - Reform Agenda towards an Efficient "Breach" Contract" (PhD Thesis, University of St. Gallen 2008)

\section{GATT Panel Reports}

Canada - Imposition of Countervailing Duties on Imports of Manufacturing Beef from the EEC GATT DOC DS SCM/85 (1987) (Report by the Panel unadopted)

Netherlands Action under Article XXIII:2 to Suspend Obligations to the United States GATT BISD 1st Supp 62 GATT DOC L/61 (1952) (Report of the GATT Working Party adopted 8 November 1952)

New Zealand - Import of Electrical Transformers from Finland GATT BISD 32th Supp 55 GATT DOC L/5814 (1985) (Report by the Panel adopted on 18 July 1985)

Norway - Procurement of Toll Collection Equipment for the City of Trondheim GATT BISD 40th Supp 319 GATT DOC GPR.DS2/R (1992) (Report of the Panel adopted by the Committee on Government Procurement on 13 May 1992)

United States - Anti-Dumping Duties on Gray Portland Cement and Cement Clinker from Mexico GATT DOC ADP/82 (1992) (Report of the Panel unadopted)

United States - Countervailing Duties on Fresh, Chilled, and Frozen Pork from Canada GATT BISD 38 Supp 30 GATT DOC DS7/R - 38S/30 (1990) (Report of the Panel adopted on 11 July 1991)

United States - Imposition of Anti-Dumping Duties on Imports of Seamless Stainless Steel Hollow Products from Sweden GATT DOC ADP/27 (1990) (Report of the Panel unadopted)

United States - Measures Affecting Imports of Softwood Lumber from Canada GATT BISD 40th Supp 358 GATT DOC SCM/162 (1993) (Report of the Panel adopted by the Committee on Subsidies and Countervailing Measures on 27 October 1993)

United States - Restriction on the Importation of Sugar and Sugar Containing Products Applied under 1955 Waiver and under the Headnote to the Schedule of Tariff Concessions GATT BISD 37th Supp 228 GATT DOC L/6631 - 37S/228 (1990) (Report of the Panel adopted 7 November 1990) 
United States - Taxes on Petroleum and Certain Imported Substances GATT BISD 34th Supp 136 GATT DOC L/6175 - 34S/136 (1987) (Report of the Panel adopted 17 June 1987)

United States Manufacturing Clause GATT BISD 31th Supp 74 GATT DOC L/5609 - 31S/74 (1984) (Report of the Panel adopted on 15/16 May 1984)

Uruguayan Recourse to Article XXIII GATT BISD 11th Supp 95 GATT DOC L/1923 - 11S/95 (1962) (Report of the Panel adopted 16 November 1962)

\section{WTO Panel Reports}

Brazil - Export Financing Program for Aircraft WTO DOC WT/DS46/R (1999) (Report of the WTO Panel)

Brazil - Measures Affecting Desiccated Coconut WTO DOC WT/DS22/R (1996) (Report of the WTO Panel)

Canada - Continued Suspension of Obligations in the EC - Hormones Dispute WTO DOC WT/DS321/R (2008) (Report of the WTO Panel)

EC Measures Concerning Meat and Meat Products (Hormones) Complaint by the United States WTO DOC WT/DS26/R/USA (1997) (Report of the WTO Panel)

European Communities - Custom Classification of Frozen Boneless Chicken Cut, Complaint by Thailand WTO DOC WT/DS286/R (2005) (Report of the WTO Panel)

European Communities - Export Subsidies on Sugar, Complaint by Brazil WTO DOC WT/DS266/R (2004) (Report of the WTO Panel)

European Communities - Measures Affecting Trade in Commercial Vessels WTO DOC WT/DS301/R (2005) (Report of the WTO Panel)

European Communities - Measuring Affecting the Approval and Marketing of Biotech Products, WTO DOC WT/DS291/R WT/DS291/R WT/DS293/R (2006) (Report of the WTO Panel)

Guatemala - Anti-dumping Investigation Regarding Portland Cement from Mexico WTO DOC WT/DS60/R (1998) (Report of the WTO Panel)

Japan - Taxes on Alcoholic Beverages WTO DOC WT/DS8/R WT/DS10/R WT/DS11/R (1996) (Report of the WTO Panel)

Korea - Definitive Safeguard Measure on Import of Certain Dairy Products WTO DOC WT/DS98/R (2000) (Report of the WTO Panel) 
Korea-Measures Affecting Government Procurement WTO DOC WT/DS163/R (2000) (Report of the WTO Panel)

Mexico - Measures Affecting Telecommunications Services WTO DOC WT/DS204/R (2004) (Report of the WTO Panel)

United States - Continued Suspension of Obligations in the EC - Hormones Dispute WTO DOC WT/DS320/R (2008) (Report of the WTO Panel)

United States - Import Measures on Certain Products from the European Communities WTO DOC WT/DS165/R (2000) (Report of the WTO Panel)

United States - Measures Affecting the Cross-Border Supply of Gambling and Betting Services WTO DOC WT/DS285/R (2004) (Report of the WTO Panel)

United States - Measures Treating Export Restraints as Subsidies WTO DOC WT/DS194/R (2001) (Report of the WTO Panel)

United States - Section 301-310 of the Trade Act of 1974 WTO DOC WT/DS152/R (1999) (Report of the WTO Panel)

United States - Standard for Reformulated and Conventional Gasoline WTO DOC WT/DS2/R (1996) (Report of the WTO Panel)

United States - Subsidies on Upland Cotton WTO DOC WT/DS267/R (2004) (Report of the WTO Panel)

\section{Appellate Body Reports}

Canada - Continued Suspension of Obligations in the EC - Hormones Dispute WTO DOC WT/DS321/AB/R (2008) (Report of the Appellate Body)

European Communities - Custom Classification of Certain Computer Equipments WTO DOC WT/DS 62/AB/R WT/DS/67/AB/R WT/DS/68/AB/R (1998) (Report of the Appellate Body)

European Communities - Regime for the Importation, Sale and Distribution of Bananas WTO DOC WT/DS27/AB/R (1997) (Report of the Appellate Body)

India - Patent Protection for Pharmaceuticals and Agricultural Chemical Products WTO DOC WT/DS50/AB/R (1998) (Report of the Appellate Body)

Japan - Taxes on Alcoholic Beverages WTO DOC WT/DS8/AB/R WT/DS10/AB/R WT/DS11/AB/R (1996) (Report of the Appellate Body) 
Korea - Definitive Safeguard Measure on Imports Certain Dairy Products WTO DOC WT/DS98/AB/R (1999) (Report of the Appellate Body)

United State - Continued Suspension of Obligations in the EC - Hormones Dispute WTO DOC WT/DS320/AB/R (2008) (Report of the Appellate Body)

United States - Import Measures on Certain Products from the European Communities WTO DOC WT/DS165/AB/R (2000) (Report of the Appellate Body)

United States - Import Prohibition of Certain Shrimp and Shrimp Products WTO DOC WT/DS58/AB/R (1998) (Report of the Appellate Body)

United States - Measures Affecting Imports of Woven Wool Shirts and Blouses WTO DOC WT/DS33/AB/R (1997) (Report of the Appellate Body)

United States - Measures Affecting the Cross-Border Supply of Gambling and Betting Services WTO DOC WT/DS285/AB/R (2005) (Report of the Appellate Body)

United States - Standards for Reformulated and Conventional Gasoline WTO DOC WT/DS2/AB/R (1996) (Report of the Appellate Body)

United States - Tax Treatment for "Foreign Sales Corporations" WTO DOC WT/DS108/AB/R (2000) (Report of the Appellate Body)

\section{Recourse to the Article 21.5 of the DSU}

Australia - Measures Affecting Importation of Salmon (Recourse to Article 21.5 of the DSU by Canada) WTO DOC WT/DS18/RW (2000) (Report of the Panel)

Australia - Subsidies to Producers and Exporters of Automotive Leather (Recourse to Article 21.5 of the DSU by the United States) WTO DOC WT/DS126/RW (2000) (Report of the Panel)

\section{Awards of Arbitrators (Article 22.6 of the DSU)}

Brazil - Export Financing Programme for Aircraft (Recourse to Arbitration by Brazil under Article 22.6 of the DSU and Article 4.11 of the SCM Agreement) WTO DOC WT/DS46/ARB (2000) (Decision by the Arbitrators)

Canada - Export Credits and Loan Guarantees for Regional Aircraft (Recourse to Arbitration by Canada under Article 22.6 of the DSU and Article 4.11 of the SCM Agreement) WTO DOC WT/DS222/ARB (2003) (Decision by the Arbitrator) 
European Communities - Measures Concerning Meat and Meat Products (Hormones) (Original Complaint by Canada) (Recourse to Arbitration by the European Communities under Article 22.6 of the DSU) WTO DOC WT/DS48/ARB (1999) (Decision by the Arbitrators)

European Communities - Measures Concerning Meat and Meat Products (Hormones) (Original Complaint by the United States) (Recourse to Arbitration by the European Communities under Article 22.6 of the DSU) WTO DOC WT/DS26/ARB (1999) (Decision by the Arbitrators)

European Communities - Regime for the Importation, Sale and Distribution of Bananas (United States) (Recourse to Arbitration by the European Communities under Article 22.6 of the DSU) WTO DOC WT/DS27/ARB (1999) (Decision by the Arbitrators)

European Communities - Regime for the Importation, Sale and Distribution of Bananas (Ecuador) (Recourse to Arbitration by the European Communities under Article 22.6 of the $D S U$ ) WTO DOC WT/DS27/ARB/ECU (2000) (Decision by the Arbitrators)

United States - Anti Dumping Act of 1916 (Original Complaint by the European Communities) (Recourse to Arbitration by the United States under Article 22.6 of the DSU) WTO DOC WT/DS136/ARB (2004) (Decision by the Arbitrators)

United States - Continued Dumping and Subsidy Offset Act of 2000 ('Byrd Amendment') (Recourse to Arbitration by the United States under Article 22.6 of the DSU) WTO DOC WT/DS217/ARB/BRA, WT/DS234/ARB/CAN, WT/DS217/ARB/CHL, WT/DS217/ARB/EEC, WT/DS217/ARB/IND, WT/DS217/ARB/JAP, WT/DS217/ARB/KOR, WT/DS234/ARB/MEX (2004) (Decision by the Arbitrator)

United States - Measures Affecting the Cross-Border Supply of Gambling and Betting Services (Recourse to Arbitration by the United States under Article 22.6 of DSU) WTO DOC WT/DS285/ARB (2007) (Decision by the Arbitrator)

United States - Subsidies on Upland Cotton (Recourse to Arbitration by the United States under Article 22.6 of the DSU and Article 4.11 of the SCM Agreement) WTO DOC WT/DS267/ARB/1 (2009) (Decision by the Arbitrator)

United States - Tax Treatment for "Foreign Sales Corporations" (Recourse to Arbitration by the United States under Article 22.6 of the DSU and Article 4.11 of the SCM Agreement) WTO DOC WT/DS108/ARB (2002) (Decision of the Arbitrator) 


\section{Others Awards of the Arbitrator}

European Communities - Regime for the Importation, Sale and Distribution of Bananas (Recourse by the United Stated to Article 22.2 of the DSU) WTO DOC WT/DS27/43 (1999) (Award of the Arbitrator)

\section{WTO Documents and Minutes Meetings}

Dispute Settlement Body Minutes Meeting - Held in Centre William Rappard on 12 December 2000 WTO DOC WT/DSB/M/94 (15 February 2001)

Dispute Settlement Body Minutes of Meeting - Held in the Centre William Rappard on 11 February 2000 WTO DOC WT/DSB/M/75 (7 March 2000)

Dispute Settlement Body Minutes of Meeting - Held in the Centre William Rappard on 19 April 1999 WTO DOC WT/DSB/M/59 (3 June 1999)

Dispute Settlement Body Minutes of Meeting - Held in the Centre William Rappard on 24-26 November 2004 WTO DOC WT/DSB/M/178 (17 January 2005)

Dispute Settlement Body Minutes of Meeting - Held in the Centre William Rappard on 7 May 2003 WTO DOC WT/DSB/M/149 (8 July 2003)

Dispute Settlement Body Special Session Amendments to the Understanding Rules and Procedures Governing the Settlement of Disputes Proposed Text by Mexico - Communication by Mexico WTO DOC TN/DS/W/40 (27 January 2003)

Dispute Settlement Body Special Session Contribution of Ecuador to the Improvement of the Dispute Settlement Understanding of the WTO - Communication from Ecuador WTO DOC TN/DS/W/9 (8 July 2002)

Dispute Settlement Body Special Session Dispute Settlement Understanding Proposals: Legal Text - Communication from India on Behalf of Cuba, Dominican Republic, Egypt, Honduras, Jamaica and Malaysia WTO DOC TN/DS/W/47 (11 February 2003)

Dispute Settlement Body Special Session Minutes of Meeting - Held in the Centre William Rappard on 13 - 15 November 2002 WTO DOC TN/DS/M/6 (31 March 2003)

Dispute Settlement Body Special Session Negotiations on Improvement and Clarifications of the Dispute Settlement Understanding - Proposal by Mexico WTO DOC TN/DS/W/23 (4 November 2002) 
Dispute Settlement Body Special Session Negotiations on Improvements and Clarifications of the Dispute Settlement Understanding - Proposal by Ecuador WTO DOC TN/DS/W/33 (23 January 2003)

Dispute Settlement Body Special Session Negotiations on the Dispute Settlement Understanding - Proposal by African Group WTO DOC TN/DS/W/15 (25 September 2002)

Dispute Settlement Body Special Session Negotiations on the Dispute Settlement Understanding - Special and Differential Treatment for Developing Countries - Proposals on DSU by Cuba, Honduras, India, Indonesia, Malaysia, Pakistan, Sri Lanka, Tanzania and Zimbabwe WTO DOC TN/DS/W/19 (9 October 2002)

Dispute Settlement Body Special Session Text for LDC Proposal on Dispute Settlement Understanding Negotiations - Communication from Haiti WTO DOC TN/DS/W/37 (22 January 2003)

Dispute Settlement Body Special Session Text for the African Group Proposals on Dispute Settlement Understanding Negotiations - Communication from Kenya WTO DOC TN/DS/W/42 (24 January 2003)

Dispute Settlement Body Special Session, Negotiations on the Dispute Settlement Understanding - Proposal by the LDC Group WTO DOC TN/DS/W/17 (9 October 2002)

European Communities - Measures concerning meat and meat products (Hormones) Communication from the European Communities WTO DOC WT/DS26/22 WT/DS48/20 (28 October 2003)

European Communities - Measures concerning Meat and Meat Products (Hormones) - Joint Communication from the European Communities and the United States WTO DOC WT/DS26/28 (30 September 2009)

Japan - Taxes on Alcoholic Beverages - Mutually Acceptable Solution on Modalities for Implementation WTO DOC WT/DS8/20 WT/DS10/20 WT/DS11/18 (12 January 1998)

Notification of Mutually Agreed Solution, Japan Measures Affecting the Importation of Apples WTO DOC WT/DS245/21 G/L/520/Add.1 G/SPS/GEN/299/Add.1 G/AG/GEN/50/Add.1 (2 September 2005)

Turkey - Restrictions on Imports of Textile and Clothing Products - Notification of Mutually Acceptable Solution WTO DOC WT/DS34/14 (19 July 2001)

United Sates - Definitive Safeguard Measures on Imports of Circular Welded Carbon Quality Line Pipe from Korea - Agreement under Article 21.3(b) of the DSU WTO DOC WT/DS202/18 (31 July 2002) 
United States - Section 110(5) of the US Copyright Act - Notification of a Mutually Satisfactory Temporary Arrangement WTO DOC WT/DS160/23 (26 June 2003)

European Communities - Measures Concerning Meat and Meat Products (Hormones) WTO DOC WT/DS26/17/Add.4, WT/DS48/15/Add.4 (11 May 1999) (Status Report by the European Communities)

European Communities - Measures Concerning Meat and Meat Products (Hormones) WTO DOC WT/DS26/22 WT/DS48/20 (28 October 2003) (Communication from the European Communities)

United States - Continued Suspension of Obligations in the EC - Hormones Dispute WTO DOC WT/DS320/1 G/L/713 (10 November 2004) (Request for Consultations by the European Communities)

Dispute Settlement Body Minutes of Meeting held on 7 November 2003 WTO DOC WT/DSB/M/157 (18 December 2003)

Dispute Settlement Body Minutes of Meeting held on 7 November 2003 WTO DOC WT/DSB/M/157 (18 December 2003)

Dispute Settlement Body Minutes Meeting 19 June 2009 - Held in Centre William Rappard on 19 June 2009 WTO DOC WT/DSB/M/270 (28 August 2009)

\section{Pre-WTO Documents}

Committee on Trade and Development - Ad Hoc Group on Legal Amendments to the General Agreement Proposals for Amendments to the General Agreement - Note by the Secretariat COM.TD/F/W/1 (27 April 1965)

Committee on Trade and Development - Ad Hoc Group on Legal Amendments to the General Agreement Proposal Submitted by the Brazilian and Uruguayan Delegations - Draft Decision on Article XXIII COM.TD/F/W/4 (11 October 1965)

Contracting Parties Ninth Session Report of Review Working Party IV on Organizational and Function Questions GATT DOC L/327 (22 February 1955)

Council of Representatives Minutes of Meeting - Held in the Centre William Rappard on 4 May 1988 GATT DOC C/M/220 (8 June 1988)

Council of Representatives Minutes of Meeting - Held in the Centre William Rappard on 22 September 1988 GATT DOC C/M/224 (17 October 1988) 
Decision of 12 April 1989 on Improvement to the GATT Dispute Settlement Rules and Procedures GATT BISD 36th Supp 61

Decision on Dispute Settlement Procedures of 30 November 1984 GATT BISD 31st Supp 9 (1984)

Drafting Committee of the Preparatory Committee of the United Nations Conference on Trade and Employment Article 86 - Summary of Points Made By Mr. Shackle Regarding Interpretation and Settlement of Disputes E/PC/T/C.6/W.77 (14 February 1947)

Final Act of the United Nations Conference on Trade and Employment: Havana Charter for an International Trade Organization E/Conf 2/78 (April 1948)

GATT Council Minutes of Meeting - Held in the Center William Rappard on 4 May 1988 GATT DOC C/M/220 (8 June 1988)

Havana Conference Reports of the Committee and Principal Sub-Committees UN.Doc. ICITO1/8 (September 1948)

Preparatory Committee of the International Conference on Trade and Employment Verbatim Report of the Tenth Meeting of Committee V - Held in Convocation Hall Church House, Westminster $\mathrm{E} / \mathrm{PC} / \mathrm{T} / \mathrm{C} . \mathrm{V} / \mathrm{PV} / 10$ (8 November 1946)

Preparatory Committee of the International Conference on Trade and Employment Verbatim Report of the Eleventh Meeting of Committee V - Held in Hoare Memorial Hall, Church House, Westminster E/PC/T/C.V/PV/11 (9 November 1946)

Proposal Submitted by the Brazilian and Uruguayan Delegation - Draft Decision on Article XXIII GATT DOC COM.TD/F/W/4 (11 October 1965)

Report of the Ad Hoc Group on Legal Amendments to the General Agreement COM.TD/F/4 (4 March 1966)

Report of the First Session of the Preparatory Committee of the United Nations Conference on Trade and Employment E/PC/T/33 (November 1946)

Report of the Second Session of the Preparatory Committee of the United Nations Conference on Trade and Employment (Adopted by the Preparatory Committee 22 August 1947) E/PC/T/186 (10 September 1947)

Report of Working Party 3 of Sub-Committee G E/Conf.2/C.6/W.80 (30 January 1948)

Sub-Comittee on chapter VIII (Settlemnt of differences-interpretation) Notes of the Seventeenth Meeting E/Conf. 2/C.6/W.102 (16 February 1948) 
Sub-Committee on chapter VIII (Settlement of differences-interpretation) Notes on the Ninth Meeting E/Conf.2/C.6/W.66 (22 January 1948)

Summary Record of the Seventeenth Meeting held at the Palais des Nations Geneva on Monday 10 October 1952 at 10am GATT DOC SR 7/17 (18 November 1952)

\section{International Law Treaties and Documents}

Gaetano Arangio-Ruiz Fourth report on State responsibility A/CN.4/444/Add.1-3 (1992)

Gerald Fitzmaurice Third Report on the Law of Treaties A/CN.4/115 (1958)

International Law Commission Draft Articles on Responsibility of States for International Wrongful Acts A/56/10 chp.IV.E.1 (2001)

James Crawford Third Report on State Responsibility A/CN.4/507 (2000)

Martti Koskenniemi Fragmentation of International Law: Difficulties Arising from the Diversification and Expansion of International Law A/CN.4/L.682/Add.1 (2006)

Responsibility of States for Internationally Wrongful Acts GA Res 56/83, A/RES/56/83 (2001)

Vienna Convention Law and Treaties 1969, Done at Vienna on 23 May 1969 Entered into force on 27 January 1980, United Nations Series Vol 1155

\section{International Law Court Decisions and Advisory Opinion}

Appeal Chambers Judgment on the Request of the Republic of Croatia for Review of the Decision of Trial Chamber II of 18 July 1997 (Prosecutor v Tihomir Blaskic) [1997] ICTY Case No IT-95-14-AR

Application of the Convention on the Prevention and Punishment of the Crime of Genocide, Preliminary Objection (Bosnia and Herzegovina v Yugoslavia) (Judgment) [1996] ICJ Rep 595

Barcelona Traction, Light and Power Company Limited (Belgium v Spain) (Second Phase) [1970] ICJ Rep 1970

Factory at Chorzów (Germany v Poland) (Indemnity) [1928] PCIJ (Series A No 17)

Legality of the Threat or Use of Nuclear Weapons International Court of Justice (Advisory Opinion) [1996] ICJ Rep 226 
Rainbow Warrior (New Zealand v France) (1990) 20 RIAA 215

S.S. "Wimbledon" (U.K, France, Italy, Japan v Germany) (Judgment) [1923] PCIJ (Series A No 1) 15

\section{National/Domestic Legislations and Reports}

Directive 2003/74/EC of the European Parliament and of the Council of 22 September 2003 amending Council Directive 96/22/EC concerning the prohibition on the use in stock farming of certain substances which have a hormonal or thyrostatic action and of beta-agonists [2003] O J L $262 / 17$

Proposal for a Directive of the European Parliament and of the Council Amending Council Directive 96/22/EC concerning the Prohibition on the Use in Stockfarming of certain Substances Having a Hormonal or Thyrostatic Action and of Beta-agonists [2000] COM (2000)0320

Public Law 106-387, 19 CFR $§ 159.61$ (2000)

Regulation $1637 / 98$ of 20 July 1998 amending Regulation 404/93 on the common organization of the market in bananas [1998] OJ L 210

Regulation 404/93 of 13 February 1993 on the Common Organization of the Market in Bananas [1993] OJ L 047

Report on the Proposal for a European Parliament and Council Directive Amending Council Directive 96/22/EC concerning the Prohibition on the Use in Stockfarming of certain Substances Having a Hormonal or Thyrostatic Action and of Beta-agonists [2001] EUR PARL DOC A5$0002 / 2001$

Suggested Charter for an International Trade Organization of the United Nations (US Department of State Publication 2598, Commercial Policy Series 93, 1946)

The Report of the International Financial Institution Advisory Commission (March 2000)

Trade and Development Act Pub L No 106-200, § 407114 Stat 251 


\section{Press Release}

European Commission "EU and Ecuador Reach Agreement to Resolve WTO Banana Dispute" (Press Release, 30 April 2001)

European Commission "EU Publishes Revised Smart Sanction to Counter US Byrd Amendment" (Press Release, 17 April 2007)

European Commission "WTO Dispute Settlement: Memorandum on Beef Hormones Dispute Signed with the United States" (Press Release, 14 May 2009)

European Union "US Congress Repeal Byrd Amendment but Allows for Transitional Period" (Press Release, 20 December 2006)

\section{Miscellaneous}

International Centre for Trade and Sustainable Development "Brazil Asks for Cross-Retaliation under TRIPS, GATS, in Cotton Dispute with US", 12 October 2005

International Centre for Trade and Sustainable Development "Brazil, US Strike 'Framework' Deal in Cotton Dispute", Bridges Weekly Trade Digest Vol. 14 No. 23, 23 June 2010

International Centre for Trade and Sustainable Development "New Issues Arise in EU-US Beef Trade Dispute Bridges Weekly Trade News Digest, Vol. 13 No. 23, 24 June 2009

International Centre for Trade Sustainable Development, "Truce Declare in Beef Hormone Dispute", Volume 3 Number 2, June 2009

Pascal Lamy, the EU Trade Commissioner "Has International Capitalism Won the War and Lost the Peace?" (the United States Chamber of Commerce, Washington DC, 8 March 2001)

US Meat Export Federation “International Market Development Activities for US Beef” Fourth Quarter FY09, 1 July - 30 September 2009 